ANGLO-SCOTTISH TRACTS, 1701-1714

\title{
A Descriptive Checklist
}

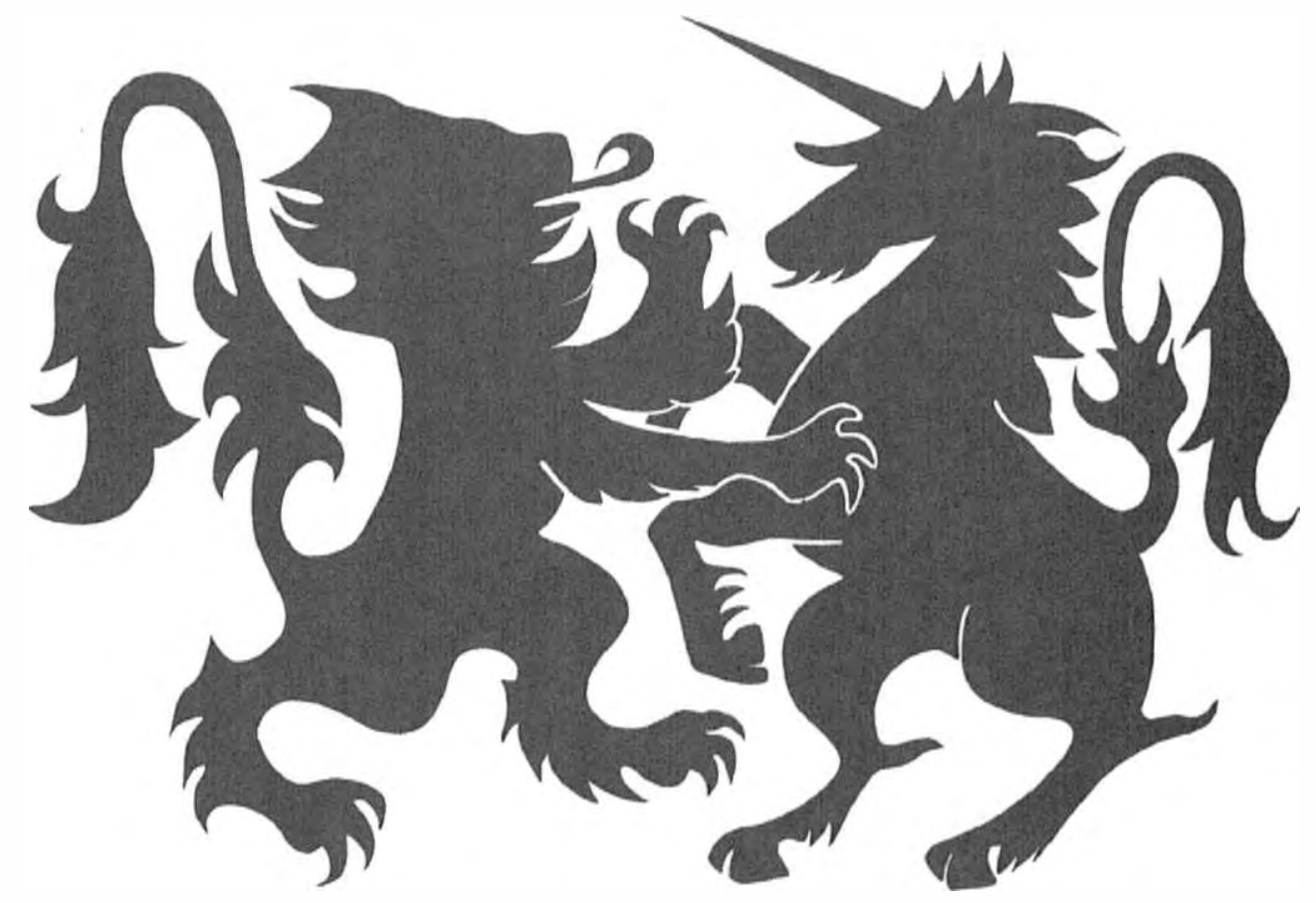

Compiled by W. R. and V. B. McLeod

UNIVERSITY OF KANSAS LIBRARIES 1979 
University of Kansas Publications

Library Series, 44 


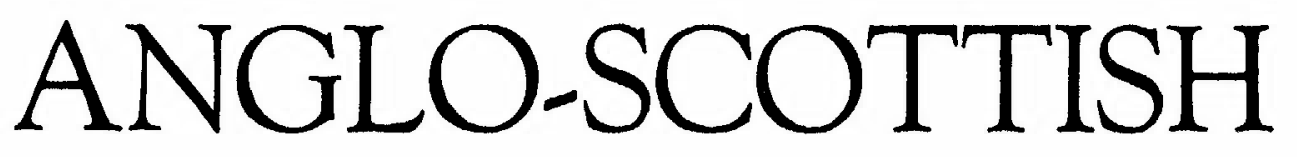

\section{TRACTS, 1701-1714}

A Descriptive Checklist Compiled by W. R. and V. B. McLeod

UNIVERSITY OF KANSAS LIBRARIES

1979 
PRINTED IN LAWRENCE, KANSAS, U.S.A., BY

THE UNIVERSITY OF KANSAS PRINTING SERVICE 
To Helen and Don 


\section{CONTENTS}

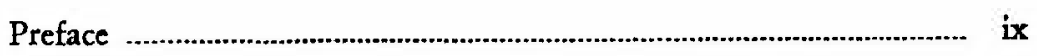

Library symbols .......................................................................... Xv

Abbreviations ................................................................................

The Checklist ................................................................................. $\quad 1$

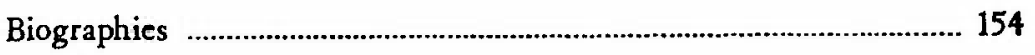

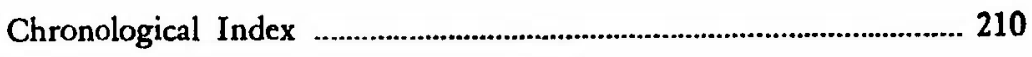




\section{PREFACE}

For some years we have been interested in various aspects of a bibliography of works published during the reign of Queen Anne, and in particular in a working checklist of Anglo-Scottish materials from the conclusion of Wing's Short Title Catalogue, 1641-1700 to Anne's death in the late summer of 1714. We originally became interested in the union of 1707 , and the vast quantity of pamphlets and other printed materials which that union and its subsequent history provoked. Even a superficial examination revealed numerous works in almost every major repository in the United States and in Great Britain; there had never been a bibliographical survey of such works and much confusion existed in contemporary as well as in later histories as to their number and content. Since some major and many more minor figures contributed writings to the Anglo-Scottish debate, both the literary and the political historian face controversy and disagreement in handling Daniel Defoe, Charles Leslie, Andrew Fletcher, George Ridpath, James Hodges, and others. Basically, this checklist attempts to do nothing more than to clear a path for the historian who seeks to write a history of the union in any or all of its many aspects, and to facilitate the study of such men as Defoe and Ridpath.

In compiling and annotating this material, we have sought to reconcile the demands of three different disciplines, each of which has its own particular and highly developed standards and procedures. It therefore should be noted that we have not attempted to write a history of Anglo-Scottish relations during the reign of Anne, nor have we attempted to assess the impact of the ideas expressed in these works upon those who were working for or against the union. Neither have we attempted to reconcile conflicting opinions as to the existence of a coherent "Scottish" or "English" position, as opposed to a more decentralizcd or sectional approach. That is better done by the historian who sets as his goal the understanding of comprehensive Anglo-Scottish relations during the reign. Nor have we attempted to analyze the literary talents or to assess the relative literary merits of those who wrote on Anglo-Scottish affairs. The tendency to identify with Defoe anything which was well written or well conceived is one which we have tried to resist, but often in vain. Much of the prose and most of the poetry was written in haste (and in heat) and by unpractised writers; and it reflects much of the stress under which it was produced. There are some-but relatively few-examples of good prose here. Because both political and literary historians form a large portion of the audience to whom this work is directed, we have had to modify and at times to do injustice to the exacting standards of the bibliographer. We emphasize that this is not a descriptive bibliography but a working checklist. We have tried to blend the needs and requirements of the literary, historical, and bibliographical profes- 
sions, and to offer as little offense as possible to any of them. To the extent that we have succeeded, we offer thanks to professionals in all three disciplines; to the extent that we have failed to provide certain information or to include additional materials, we offer our apologies and our assistance in further research.

In view of the vast amount of material published in the reign of Queen Anne and the highly political atmosphere of that period, we found it necessary to impose rather strict limitations upon what we should or should not include in this Anglo-Scottish checklist. We wanted to bring together materials published between 1701 and 1714 which were directly involved with issues in debate between England and Scotland. Although the union was the focus (indeed, the most important single event in the reign of Anne relative to Anglo-Scottish affairs), there were peripheral issues leading up to or away from it which had to be included as well. Since the union was one of two kingdoms which differed in economic, religious, political, and legal matters-to cite only the more obvious - the debate ranged over a wide variety of topics; and the consequences affected not only the obvious but also the less evident aspects of life in both parts of Britain. The problem of definition, therefore, was one of great importance; and the matter of selection acquired a mounting significance. In order to facilitate understanding of the limits of this work, we have included the following list of parameters in the hope that it will assist all who wish to use this checklist.

1. Works published in English are included; those in other languages or those translated into English are not.

2. All works were published in England, Scotland, or Ireland; we have not included the few authentic foreign and American imprints. When the place of publication has been in doubt, we have included rather than excluded the item.

3. All works included were published in the years from 1701 to 1714 . We took the end of the last year of Wing's Short-Title Catalogue as our beginning date, and have sought to include all works published before August 1, 1714, if a publication date in 1714 could be determined. Works known to have been published after 31 July 1714 have been excluded; if only the date 1714 was known and there was no other means of exclusion, the item was retained.

4. Official publications have been excluded. The union generated a vast number of official publications, including speeches by Anne and her ministers, proclamations, acts, and the Articles of Union themselves.

5. Collections of poetry which include only random items relating to the union have been omitted, as have collections of poetry designated as "Scottish" but with no other relation to the Anglo-Scottish debate.

6. Songs designated as "Scottish" also have been deleted (they rarely if ever had anything Scottish about them at all).

7. Items published before and reprinted after 1701 also have been eliminated, unless they were modified or a preface or postscript affixed to them to make them more topical. 
8. Works written before 1701 but published only after 1701 have been excluded unless they had been altered to reflect contemporary problems of the reign of Anne.

9. General histories, yearly journals, and parliamentary accounts which briefly treated Anglo-Scottish affairs or which commented in passing on Scotland have not been included. Our rule of thumb has been that the work must be predominantly about Anglo-Scottish affairs in the reign of Anne in order to be included.

10. The only plays included are those which clearly dealt with the union or with Anglo-Scottish affairs in the reign of Queen Anne. We have not attempted to record those plays which might be interpreted as reflecting in passing upon Scotland or the union.

11. Official publications of such organizations as the Company of Scotland have been included when they pertained to relations between the two countries. Purely routine announcements have been excluded as have petitions by individuals associated with such organizations, unless such documents were directly pertinent.

12. Jacobite materials have been included only if they are directly related to Anglo-Scottish affairs. That movement existed both in England and in Scotland; indeed there were Jacobites at all levels of society in both countries. Jacobitism was neither a Scottish movement nor a part of the Anglo-Scottish debate as such. Admittedly some Jacobite material was directed at the union, and that material has been included; but no tract has been included simply because it was concerned with the Pretender.

13. Religious tracts which dealt with earlier or contemporary relationships between Presbyterianism and Anglicanism, or Presbyterian and Episcopal principles, have been excluded unless they pertained to Anglo-Scottish relations. Differences between Anglicans and Presbyterians within England, or between Presbyterians and Episcopalians in Scotland, were numerous and deeply rooted in century-old rivalries. The inclusion of such materials would have trebled the number of entries without significantly advancing an understanding of Anglo-Scottish relations.

14. Pamphlets which discussed Scottish affairs only incidentally or which included sections dealing with particular Anglo-Scottish problems have been included only if those sections played a large role in debates or if they constituted an integral or important theme of the pamphlet as a whole. More often, such references were casual, of no particular importance within the pamphlets, or not vital to their arguments; in these cases, they have been omitted.

15. Throughout this checklist we have included only those works and editions which we have been able to examine personally.

In all cases, we have attempted to follow the rules of common sense, making admittedly individual and perhaps arbitrary decisions. The student of the 
period may be assured, however, that every effort has been made to include anything which legitimately might be expected in such a checklist.

At this point, a few words on the form and style of the individual entries may be of further assistance to those using this checklist.

Title. While every attempt has been made to give full titles, we have not tried to reproduce capitalization from the title pages. Punctuation, however, has been copied as closely as possible. Mottoes, authors' names, and other omissions are marked by ellipses. Materials from mutilated sections of copies or explanations of blanks (e.g., my lord $\mathrm{H}_{-}-\mathrm{m}$ ) are given in square brackets. Where there might be confusion or where the original spelling resembles a typographical error, (!) has been inserted. No doubt there are, however, typographical errors which have passed unnoticed.

Imprint. As in the case of the title, we have attempted to give full imprints; again, no effort has been made to reproduce capitalization. If there is no imprint for an item, but if it may be deduced from content, type face, or other sources, it is given in square brackets. If that attribution is not certain, it is followed by a question mark.

Date. The question of the accurate dating of works is one which plagues all scholars of the eighteenth century. Although some of the items included in this checklist have a date either on the title page, in the colophon, or somewhere in the work itself, others have nothing of the sort. We have attempted to date as many of these tracts as possible, from both internal and external sources. If it has been possible to date a tract within a year, that information is given in parentheses following the year. For works where the date is conjectural, if we are fairly certain of the year, the entry will appear as [1710?]; if there is more uncertainty, we have followed D. F. Foxon's example in his English Verse 1701-1750 and have used the terminal dating system. Therefore, if a work refers to the union as being in effect and also to Queen Anne, but we are unable to narrow the date of publication any further, it is dated [1707/1714]. If we have accepted dating from an external source-another pamphlet, a newspaper, a secondary work, a manuscript note in a contemporary hand, or Defoe's letters, for example-we have included that date without reservation. However, we have not cited newspaper advertisements as such; our forthcoming publication on books and tracts advertised in the newspapers and periodicals of the reign of Queen Anne will give complete listings for all works advertised during the entire reign-including these Anglo-Scottish tracts. Dating, therefore, should be regarded as suggestive, and always should be handled with extreme care.

Bibliographical Information. We have followed standard bibliographical procedures as formulated by Gaskell, with the following exceptions: we have used Bowers' suggested symbols " $1{ }^{\circ}, 1 / 2{ }^{\circ}, 1 / 4^{\circ}$ " for unfolded single, half, and quarter sheets, rather than the more unwieldy "s.sh., s.sh.fol.," etc.; we also have followed a modified version of Foxon's scheme of pagination, and therefore 
have not included advertisements and errata pages as consistently as he has done; finally, we have not distinguished those tracts with drop titles.

Author Attribution. If an author's name appears on the title page, preliminary materials, or the tract itself, we have recorded that information. If we are attributing to an author an anonymous or pseudonymous tract, his name is given in parentheses. If a tract formerly has been attributed to an author but we do not accept that attribution, we have entered it as follows: (anonymous; formerly attributed to Daniel Defoe) or (Daniel Defoe; although sometimes attributed to William Forbes). For the most part we have adopted the more logical attribution; often this has coincided with the more frequent one; at other times it has not.

Locations. In compiling materials for this work we have cited items located in nine libraries: the British Library, the National Library of Scotland, the Bodleian Library, and the Goldsmiths' Library in Great Britain; the Yale University Library, the Folger Shakespeare Library, the Indiana University Library, the Harvard University Library, and the University of Kansas Library in the United States. As will be observed, our major sources have included not only the older and longer-established collections in Britain and along the east coast of the United States, but also the newer but equally important collections, such as the Kenneth Spencer Research Library at the University of Kansas, the Lilly Library at Indiana University, and the eighteenth-century holdings of the Folger Shakespeare Library in Washington. It should be emphasized that we have not attempted to list all locations for any single item in this bibliography. This is not an exhaustive record of holdings throughout the western world; rather, we have cited items in libraries which are most accessible to the scholar, which have means of photo-reproduction available, and which generally are open to all working scholars. If an item was not available in any of these nine libraries, we used the more rare items in other repositories. For the American libraries, the National Union Catalogue symbols have been utilized; for the British libraries, the standard $\mathrm{L}, \mathrm{E}$, and $\mathrm{O}$ have been used for the first three mentioned. We have altered the LU symbol to LU-G to designate the Goldsmiths' Library, which is the only part of the University of London's holdings that we have used in this work. The only other non-standard symbols we have used are LLI for the Lincoln's Inn Library in London, and ESR for the Scottish Record Office in Edinburgh. For the most part all $\mathrm{CtY}$ holdings are to be found in the Beinecke Rare Book and Manuscript Library, all InU items in the Lilly Rare Book Library, and all KU items in the Kenneth Spencer Research Library.

Perhaps our most pleasant task in this preface is extending our thanks to the many people who have helped us see this work to completion. First of all, we would like to thank the American Philosophical Society, the Claude Worthington Benedum Foundation, and Dean Guy H. Stewart of the P. I. Reed School of Journalism at West Virginia University for their financial support 
of this project. We owe a special thanks to Ms. Hilary E. Flenley who cheerfully searched through the records of the Edinburgh libraries for leads on obscure Scottish divines, as well as any other esoteric questions we sent her. We also would like to express our great appreciation to Dr. J. A. Downie of the University of London and to Dr. Henry L. Snyder of Louisiana State University, for their patient reading of this manuscript in one of its earlier forms; to Professor Donald Greene of the University of Southern California, for his unflagging moral support; and to Professor G. S. Holmes of the University of Lancaster, and Dr. P. W. J. Riley of the University of Manchester, for their critical comments and helpful suggestions regarding various parts of the manuscript. We also would like to express our gratitude to London House for Overseas Graduates on Mecklenburgh Square, and to Joseph Christopher Gluck, for the cover design.

Our longest list of thanks goes to the staffs of the various libraries where we have worked over the past few years. In particular, though, we want to thank Mr. C. G. Cordeaux at the Bodleian Library, Miss Margaret Deas at the National Library of Scotland, Miss M. B. C. Canney at the Goldsmiths' Library, Miss Geneva Warner at the Lilly Library, Miss Marjorie Wynne at the Beinecke Library, Ms. Jessica Owaroff at the Houghton Library, Ms. Sandra Powers at the Folger Library, Mr. Carey Bliss at the Huntington Library, and Miss Ann Williams at the Spencer Library. Finally-and most important-we want to thank Mr. D. L. Paisey and his ever-helpful, ever-genial staff in the North Library of the British Library, without whose assistance and patience this book would literally have been impossible.

Morgantown, 1979

W.R.M.

V.B.M. 


\section{LIBRARY SYMBOLS}

\section{Great Britain}

E

EN

ESR

GU

L

LG

LLI

LU-G

MC

MR-C

Nw-P

$\mathrm{O}$

USA

$\mathrm{CSmH}$

$\mathrm{CtY}$

DFo

ICN

IU

InU

$\mathrm{KU}$

$\mathrm{MB}$

$\mathrm{MH}$

OCU

RPBJCB

$\mathrm{TxU}$

National Library of Scotland, Edinburgh

New College Library, Edinburgh

Scottish Record Office, Edinburgh

Glasgow University Library

British Library, London

Guildhall Library, London

Lincoln's Inn Library, London

Goldsmiths' Library, London University Library

Chetham's Library, Manchester

Crawford Deposit, John Rylands Library, Manchester

Central Library, Norwich

Bodleian Library, Oxford

Henry E. Huntington Library, San Marino

Yale University, New Haven

Folger Shakespeare Library, Washington

Newberry Library, Chicago

University of Illinois, Urbana

Indiana University, Bloomington

University of Kansas, Lawrence

Boston Public Library

Harvard University, Cambridge

University of Cincinnati

John Carter Brown Library, Providence

University of Texas, Austin

\section{ABBREVIATIONS}

Aitken

George A. Aitken, The Life and Works of John Arbuthnot, M.D., Fellow of the Royal College of Physicians, 1892.

Arber

Edward Arber, ed., Term Catalogues, 1668-1709, 1903 ("A catalogue of books ....").

Beattie

Lester M. Beattie, John Arbuthnot, Mathematician and Satirist, 1935. 
Bib.Linds. Bibliotheca Lindesiana: Cataloguc of English Broadsides 1505-1897, 1898 (1968).

Blanchard Rae Blanchard, Tracts and Pamphlets by Richard Steele, 1944, 1967.

Burch I Charles Eaton Burch, "Defoe's 'Some Reply to Mr. Hodges and some other authors'," Notes and Queries, 1948, 21 February, pp. 72-74.

Burch II Charles Eaton Burch, "The authorship of 'A Scots Poem'," Philological Quarterly, XXII, 1943, pp. 51-57.

Coombs Douglas Coombs, The conduct of the Dutch; British opinion and the Dutch alliance during the War of the Spanish Succession, 1958.

Davis \& Ehrenpreis Herbert Davis and Irvin Ehrenpreis, eds., Jonathan Swift. Political Tracts, 1713-1719, 1964.

Defoe, History $\quad$ Daniel Defoe, The history of the union of Great Britain, 1709. $D N B$ Dictionary of National Biography.

EHR English Historical Review.

Ellis

Frank H. Ellis, "Defoe Disinformation," Notes and Queries, n.s. XXI, 1974, pp. 46-47.

Fasti

H. Scott, Fasti ecclesiae Scoticanae. The succession of ministers in the parish churches of Scotland from the reformation, 1560, to the present time, 1866-1871, 6 vols.; new ed., 1915-1928, 7 vols.; vol. 8, 1950.

Foxon $\quad$ D. F. Foxon, English Verse 1701-1750, 1975, 2 vols.

$H W L$

The History of the Works of the Learned: or, an impartial account of books..., 1699-1712.

Hanson L. W. Hanson, Contemporary printed sources for British and Irish economic history, 1701-1750, 1963.

Healey G. H. Healey, ed., The Letters of Daniel Defoe, 1955. This abbreviation has been used for the text of Defoe's letters as well as for Healey's footnotes.

Kennett

Lee

Macfie

Mathieson William Law Mathieson, Scotland and the union; a history of Scotland from 1695 to 1747, 1905. 
Maxwell

Thomas Maxwell, "The Presbyterian-Episcopalian controversy in Scotland from the revolution settlement till the accession of George I . . .," 1954, Edinburgh University (Ph.D.).

Moore John Robert Moore, A checklist of the writings of Daniel Defoe, second edition, 1971.

Moore, Defoe in the Pillory John Robert Moore, Defoe in the Pillory and other studies, 1939.

POAS Frank H. Ellis, ed., Poems on Affairs of State, vol. VII: 17041714, 1975.

PQ Philological Quarterly.

Ridpath "Correspondence between George Ridpath and the Rev. Robert Wodrow," Miscellany of the Abbotsford Club, vol. I, pp. 355-381.

Sedgwick Romney Sedgwick, The House of Commons, 1715-1754, 1970, 2 vols.

SHR Scottish Historical Review.

Snyder/Clare Henry L. Snyder, "The reports of a press spy," The Library, 5th series, vol. XXII, 1967, pp. 326-345.

Speck

F. F. Madan, A critical bibliography of Dr. Henry Sacheverell, edited by W. A. Speck, 1978. 


\section{A DESCRIPTIVE CHECKLIST OF}

\section{ANGLO-SCOTTISH TRACTS, 1701-1714}

1 An abstract of the act for laying duties on malt, mum, cyder and perry, 1713: [That is, so much thereof as relates to the duties and penalties appointed by the said Act.]. [Edinburgh]. 1713. $12^{\circ} ; 12$ pp. L

Although morc of an official document than most in this checklist, this was a part of the larger controversy over the imposition of the malt tax in Scotland in 1713. The Scots were furious at what they saw as a breach of the Treaty of Union, and therefore no serious effort was made to collect this particular tax.

2 An abstract of the acts of Parliaments of the kingdoms of England and Scotland, for establishing the East-India Companies of each respective kingdom; and observations thereupon, in relation to the case of the ships Annandale and Speedwell. [1710?]. $1 / 2^{\circ}$; both sides. MC

This account of the fates of the Speedwell and Annandale was published ca. 1710 to publicize and advance the case of the owners and investors of these ships, ruined by the clash between the English and Scots East India Companies. By the date of this "abstract," the original extremely complicated case had been dropped. Now at stake was the disposition of the cargo of the Annandale, which had been seized in London by the English East India Company's officials.

3 An abstract of what was spoke in Parliament by E. C. $1705.4^{\circ} ; 1-2$ 3-8 pp. (George Mackenzie, Earl of Cromarty.) L, E

The author of this tract was himself for union, and indeed for an incorporating union at that. But the obvious problem was opposition in the Parliament of Scotland not only to any union, but to England in general and to recent English "slights" to Scotland in particular. The pamphlet sought to soothe ruffled feathers in the Parliament; to derogate the actions of the English without angering them; and to encourage men to accept not only a union, but to nominate commissioners able to work with the greatest possible freedom. It was a difficult task, worthy of its attributed author.

4 An accompt current betwixt Scotland \& England ballanced: togeter (!) with an essay of a scheme of the product of Scotland, and a few remarks on each. As also a view of the several products of the ports or nations we trade to, by comparing and holding forth how our products and manufactures may ballance theirs, with returns. ... Edinburgh, printed by the heirs and successors of Andrew Anderson, printer to the Queen's Most Excellent Majesty, City, and Collcdge. 1705 (after 25 July). $4^{\circ}$; (i-iv) 1-11 1-27 28 pp. (postscript, errata, 28). John Spreull. L, E, LU-G (lacking i-iv, 1-27), DFo, InU, MH

The legal restrictions which England would impose upon the Scots and their exports to England if terms were not reached between the two, provoked a furious reaction in Scotland, where anti-English feeling already was high. This tract by a merchant in Scotland 
sought to survey the actual or potential resources of Scotland, and to show how Scotand might retaliate against English goods while at the same time increasing the consumption of native products and encouraging additional exports. It was an interesting examination of the state of Scottish manufacture and trade in 1705.

5 An accompt of the dreadful battle of whales, or sea monsters, in the Firth of Edinburgh the 25 of April instant 1707. [1707]. $12^{\circ}$; one side.

The appearance of some 35 whales, stranded on the sands of Kirkaldy just days before the Act of Union came into effect, could not pass without observation by all concerned as to its meaning. This rather clever account presented several such interpretations, concluding with the sensible one that they had been stranded after a high tide. The event was an actual one.

6 An account of a conversation concerning a right regulation of governments, for the common good of mankind. In a letter to the Marquess of Montrose, the Earls of Rothes, Roxburgh, and Haddingtoun, from London the 1st of December 1703. London: Printed for A. Baldwin. 1704 (HWL, May). $8^{\circ} ; 1-23-64$ pp. (ANDREW Fletcher). E

$\mathrm{O}, \mathrm{CtY}, \mathrm{DF}$, $\mathrm{MH}$

[variant:] ... Marquiss of Montrose, ... Roxburg, and Hadington, from London the 1st of December, 1703. Edinburgh. 1704. $8^{\circ} ; 1-23-92$ pp. $\mathrm{KU}$

This famous work, cited by Fletcher's biographers as his most attractive political essay, took the form of a conversation among men representing varied political views: Seymour was the representative John Bull figure; Musgrave the tolerant Englishman; Cromarty the tolerant pro-union Scots tory; and Fletcher the Scots patriot. Many topics of current interest were cxplored, including union and the nature and character of the two kingdoms. It was, and remains, an excellent survey of contemporary ideas and politics.

7 An account of lay-patronages in Scotland, and of the fatal differences they have occasion'd betwixt the church and lay-patrons, with observations on the arguments for restoring them. London. 1712 (Kennett, 5 April). $8^{\circ} ; 1-2$ 3-20 pp. (Sir David Dalrymple.) E, O, CtY, DFo, InU, MH

\section{3-16 pp. E}

This tract was a part of the controversy over lay patronage which so angered Scotland in 1712-1713. This author argued that lay patronage had little historical bisis in Scotland and that it had been abolished by the reformation. He argued that it would do littlc but antagonise Scotland if it were imposed upon her by England. He hoped for religious, political, and legal rensons that it would be allowed to lapse.

8 An account of the burning of the Articles of the Union at Dumfries, These are to notifie to all concerned, what are our reasons for, and designs in the burning of the printed articles of the proposed union with England, with 
the names of the Scots commissioners, subscribers thereof; together with the minuts of the whole treaty, betwixt them and the English commissioners thereanent. [Edinburgh?]. 1706 (Healey, no later than 28 November; Defoe History, ordered burned 30 November). $12^{\circ}$; one side. L, E, DFo

As stated in the title, this proclamation or account was printed to explain why the Articles of Union were burned at Dumfries. The protesters-mostly Cameronians-were most displeased with the religious provisions of the articles. Here, as elsewhere, opposition to union carried a strong religious flavor.

9 An account of the late Scotch invasion; as it was open'd by my Lord Haversham in the House of Lords on Fryday the 25th of February, 1708/9. With some observations that were made in the $\mathrm{H}-$ se of $\mathrm{C}$-ns, and true copies of authentick papers. In a letter from a gentleman in South-Britain to his friend in North-Britain. [London]. 1709 (Arber, Easter/Trinity, 1709). $4^{\circ}$; 1-4 5-48 pp. L, E, O, LU-G, CtY, DFo, InU, MH

$$
\text { 1709. } 4^{\circ} ; 1-23-20 \text { pp. E }
$$

[variant:] ...H--se of C-ns; and ... gentleman in South-Brittain to his friend in North-Brittain. . . . Sold by the booksellers of London and Westminster. 1709. $8^{\circ}$; $12-16$ pp. L, E, O, KU

The likelihood of Jacobite invasion of Great Britain reached a crest in February-March 1708. The opposition in Parliament, led by Harley, used the occasion to argue that Britain was ill-prepared and that the ministry had been negligent in its duty. This tract made those charges against the government, and introduced documents to prove the case. Scotland is more the setting than the objective of this pamphlet.

10 An account of the proceedings of the Parliament of Scotland, which met at Edinburgh, May 6. 1703.... [London] Sold by B. Bragg in Ave Mary Lane. 1704 (Arber, Hilary, 1703/4; HWL, February; published ca. 10 February). $8^{\circ}$; (i-xvi) $1-505352-545756-58610961-6265 \quad 64-118191 \quad 120-122$ 105 124-128 132 130-131. 129 133-336 339-355 $346257358-368369-370$ pp. (GEORGE Ridpath.) L, E, O, InU, MH, KU

This history of the Parliament of Scotland which met during the summer of 1703, was not only an account of the events within that Parliament, but an interpretation of the actions (and reasons for them) by one deeply involved in the political and religious issues under discussion. Although pro-Presbyterian and pro-Scottish in its bias, it is nevertheless most useful for an understanding of the events of a turbulent Parliament.

11 An account of the Scotch plot, in a letter from a gentleman in the city, to his friend in the country. London. $1704.4^{\circ} ; 1-4$ pp. L, E, O

$$
\begin{aligned}
& \text { London. 1704. } 4^{\circ} ; 1-4 \text { pp. E, O, InU } \\
& \text { nd. } 4^{\circ} ; 21-24 \text { pp. CtY }
\end{aligned}
$$

Jacobitism extended far beyond the confines of the Highlands, the Episcopalians, or Scot- 
land, and the Scots resented any attempt to consider Scotland and Jacobitism as interchangeable labels. Capt. Simon Frazer, a fugitive from justice in Scotland, had revealed a plot-the so-called Scots Plot-to the government, and had accused many prominent Scotsmen of involvement in it. The author was anxious to cmphasize the character of Captain Frazer and the infamous crimes credited to him, and, thereforc, the folly of: believing him.

12 The Act of Security, is the only rational method of procuring Scotland a happy constitution, free from illegal invasion of it's liberties and laws, and the base usurpation of it's ancient sovereignty. ... [Edinburgh?]. 1704. $4^{\circ} ; 1-3$ 4-7 8 pp. L, LU-G

The decayed position of Scotland since 1603 was a constant refrain; and this author, after recounting the manifest woes and problems of that kingdom, argued that the Act of Security was therefore essential to secure an equality between England and Scotland sufficient to force England to treat with Scotland in good faith. Mistrust of England was rampant; Scotland's need to assert her independence was essential, and the Act of Security was needed to gain that end. Union, while not rejected, could be effected only if Scotland could demand her due. It was a pamphlet written in anger by a Scot to further Scotland's interest as he saw it.

13 The Act of the Parliament of Scotland, for the security of the kingdom. As it is voted, and past in this present Parliament, and lies ready for the royal assent. With a short account of it, and some few remarks. . . L London. 1703. $4^{\circ} ; 1-23-78$ pp. E, O

The remarks affixed to the official statement of the Act of Security in Scotland attempted to present that provision to the English in the best possible light, and to justify as legitimate, rational, and modcrate action an act certain to arouse the English to retaliation.

14 Additional reasons against the exportation of wooll. $2^{\circ} ; 1-3$ (4 blk.) pp. [1704/1706]. E

The dispute between those in Scotland who wished to export wool and those who wished to encourage the cxportation of finished cloth was reflected in this tract, which sought to give reasons why the production of cloth was more advantageous than the exportation of raw wool.

15 The advantages of Scotland by an incorporate union with England, compar'd with these of a coalition with the Dutch, or league with France. In answer to a pamphlet, call'd, The advantages of the Act of Security, \& cc. To which is added, a post-script in answer to the letter concerning the consequence of an incorporating union. $1706.4^{\circ} ; 1-23-3536 \mathrm{pp}$. (anonymous, although formerly attributed to Daniel Defoe). L, E, LU-G, CtY, DFo, InU, MH, $\mathrm{KU}$

The author of this pamphlet sought to refute, argument by argument, the anti-union ideas advanced by Abercromby in No. 16. In great part he did nothing more than show the illogical and irrational nature of most of Abercromby's objections. He denied the collapse 
of trade, and countered that the reasons why some merchants objected to union might be personal trading interests; he denied that moneys flowed out of Scotland to England or that Scotsmen were lost in English battles. The petitions so often cited, he said, were from obscure men in obscure places, and were not representative. He concluded with a long counter-plea for a union which would bring the economic advantages needed in Scotland. This, along with Nos. 103 and 135, was answered in No. 331.

16 The advantages of the Act of Security, compar'd with these of the intended union: founded on the revolution-principles publish'd by Mr. Daniel De Foe. Or, the present happy condition of Scotland, with respect to the certainty of its future honourable and advantageous establishment; demonstrated. Wherein is shew'd, that both the projected union, and a nomination of a successor to the crown, tho' with limitations, cannot fail to compleat the miseries of this kingdom; but that the Act of Security alone, if adher'd to, will infallibly retrive our lost happiness, and make us a rich and glorious people. [Edinburgh]. 1706. $4^{\circ} ; 1-23-36$ pp. (Patrick Aвercromby.) L, E, LU-G, $\mathrm{CtY}, \mathrm{DFo}, \mathrm{InU}, \mathrm{MH}, \mathrm{KU}$

The union as presented to Scotland by the articles was totally unacceptable to this author, who deplored not only the past and present poor state of Scotland, plucked by the English, but the future plight of Scotland swallowed by England as well. He denied the right of a Scottish Parliament to give Scotland away without approval of the populace, and he far preferred an independent and strong Scotland to a dependent and disappearing one. He wished for a revival in Scotland sufficient to allow her to treat on equal terms with England, or-and he did not rule out the possibility-to treat with others, even with France, if need be. It was a strong, emotional affirmation of Scottish independence and a determined attack upon England. It was answered in No. 15, which in turn provoked a response in No. 331 .

17 Advertisement from Daniel Defoe, to Mr. Clark. [Edinburgh. 1710] (Moore, before November). $4^{\circ} ; 12-4$ pp. Daniel Defoe. E, CtY

Defoe in this short paper demanded the last word in the Clark-Defoe controversy. He claimed that he was tired of the entire matter, that he had sought to verify his account of Clark's words and actions, that worthy men of Glasgow had testified to his honesty in the recounting of Clark's actions, and that he therefore stood by his History (No. 162) as it was written. The controversy was: Nos. 162, 283, 311, 28, 182, 336, 17.

An advertisement from Scotland to England: In a letter from a gentleman in North-Britain, to a member of the British Parliament, in South-Britain. [Edinburgh] Printed by John Reid Junior, in Liberten's Wynd. 1710 (dated 10 August). $4^{\circ} ; 12-4$ pp. (James Clark.) L, E

By August, 1710, rumors of changes to be made in the government were current throughout England and Scotland. This pamphlet, written by a staunch Presbyterian who opposed the union, was a defense of the current government and an appeal to England to stand fast with that government, which had won victories at home and abroad. In part it reflected the fear of the more fanatical Presbyterians, that a change might bring to power the more fanatical high Anglicans in England and thus threaten the Church of Scotland. 
19 Advice to the electors of Scotland, about chusing members for next Parliament. [Edinburgh? 1708]. $4^{\circ} ; 12-4$ pp.

This piece was written to influence the elections of May, 1708, in Scotland. The author was particularly concerned that Scottish complaints relative to the implementation of the Act of Union, and of the eighth article relating to trade and commerce, were being ignored, and that the problems of the fishing industry had been given little attention in the previous Parliament. He urged the election of men dedicated to the best interest of the Scots, and willing to demand that all terms of the treaty be respected and implemented. ment for North-Britain, concerning the fishery and drawbacks. Edinburgh. 1708. $2^{\circ} ; 1-34$ pp. E

The eighth article of the Treaty of Union was designed in part to encourage and protect the Scottish fishing industry through a series of "draw-backs" on the exportation of certain fish, and other inducements. However, the Act of Union and the ministry then in power had failed to make administrative provisions for such a payment. This pamphlet was part of a successful attempt after the passage of the Act of Union to place draw-backs on a firm legal and administrative base. The rightcous indignation of the Scots over this flagrant violation of a clause in the treaty which was of particular interest to them is evident in the stringent tone of this pamphlet.

21 Aesop in Scotland, exposed in ten select fables relating to the times... . London. 1704. $8^{\circ} ; 12-8 \mathrm{pp}$. $\mathrm{O}, \mathrm{MH}$

Translations of the Fables of Aesop were especially favored in the late seventeenth and eighteenth centuries, and it was inevitable that someone would tackle the problems of Scotland in this form. The succession, Darien, and other problems were dealt with in Aesopian fashion.

22 An alarm from the north; or, the Covenant the basis of Presbytery. London: sold by J. Morphew, near Stationers-Hall. 1713. $8^{\circ}$; (i-iv) 1-18 pp. L, O, CtY, DFo, InU

At no time were the Scots Presbyterians popular among the high Anglicans of South Britain, but the author of this tract was particularly vehement in his fear of the Presbyterians to the north. He took some of the extreme statements of the more radical Scots covenanters (who on occasion during the reign of Anne renewed their pledge) and argued that they represented the inclinations of all Scots Presbytcrians. It was a pamphlet calculated to appeal to the more irrational fears among those in the south.

23 The ale-sellers complaint, upon taking down the ale-barrels, being a discourse between a brewar, a vintner and a gauger on that subject. [Edinburgh. 1708]. $2^{\circ} ; 1-4$ pp. L

Among the differences between England and Scotland was that of measures, and in particular, differences in the gauging of ale. This pamphlet is merely a discussion of the different types of measures applicable in each country and how they relate, as seen by those involved in the ale trade in England and Scotland. 
24 The anatomy of an equivalent, by the Marquess of Halifax, adapted to the equivalent in the present articles, 1706. [Edinburgh. 1706]. $4^{\circ} ; 1-8 \mathrm{pp}$. L, E, LU-G, MH

The equivalent-or moneys paid to Scotland by England to compensate the Scots for assuming the larger English national debt-was held by some Scots to be little more than a bribe, either directly or to the investors in the Company of Scotland. This author, who most certainly was against any union, objected most decidedly not only to the equivalent. but also to the very usc of the term. Scotland was unable to bargain in freedom; being thus intimidated, she had no option but to accept what she could. Little is borrowed from Halifax except the title.

And what if the Pretender should come? Or, some considerations of the advantages and real consequences of the Pretender's possessing the crown of Great-Britain. London: printed, and sold by J. Baker, at the Black Boy in Pater-noster-row. 1713 (L ms. note; Moore, $23 \mathrm{March}$ ). $8^{\circ}$; 1-2 3-40 pp. (Daniel Defoe.) L, E, O, DFo, InU, MH

The second edition. London: printed, and sold by J. Baker, at the Black Boy in Pater-noster-row. 1713. 8 ; 1-2 3-40 pp. E, CtY, InU

While primarily a tract against the Pretender, this work included Scotland because of its attentions to his cause. The discontent in Scotland was said by the author to be sufficient to ensure that the Pretender would receive a good reception, be he a Papist or not. It was irony of the first order, and a work for which the author was justifiably famous.

26 Answer to a letter concerning trade, sent from several Scots gentlemen, that are merchants in England, to their countrymen that are merchants in Scotland. Edinburgh. 1706 (dated 7 December; E ms. note, 30 December). $4^{\circ} ; 1-8$ pp. (William Black.) L, E, LU-G MH

The complex cconomic issues-salt, fishing, woolens, linen, and malt-involved in the union debate continued to plague, everyone into the autumn and winter of 1706-1707. Black, in this rebuttal to Defoe's No. 193, continued to hammer away at the treaty on the grounds that it did not take into account the peculiar character of Scottish trade and industry: England traded with different places and handled different goods. He claimed that Defoe simply did not understand Scottish problems, and his defense of the treaty, therefore, did not in Black's opinion resolve the major problems. Defoe's No. 193 had been a response to Black's earlier No. 408 and 412.

27 An answer to a pamphlet, intituled, The Oath of Abjuration displayed: wherein all that is therein advanced to prove the sinful nature and tendency of the said oath, in its alledged inconsistency with Presbyterian principles \& covenants; and security it affords the Church of England, is fully obviated; the conduct of ministers at the taking of the said oath vindicated; and the ignorance \& calumnies of the displayer are detected.... 1713. $4^{\circ}$; 1-3 4-5 $67-58 \mathrm{pp}$. (JoHN M'Murdo.) E, KU

The more extreme wing of the Presbyterian church as well as those outside it who felt that the church compromised too much, found the Oath of Abjuration too compromising 
of religion to be taken with a clear conscience. Their doubts were expressed in No. 269, and it was to that pamphlet that this author addressed his at times caustic words. This was a "no nonsense" pamphlet by one who had suffered more than enough at the hands of the extremists and who was ready now to fight back with historical precedents, with common sense, with logic, and with annoyance at the humorless, nit-picking, self-righteous work of the Hepburnites and other extremists. It was a tract which fought for moderation and toleration and which sought to show how men with convictions might take the oath in good conscience.

28 An answer to a paper concerning Mr. DeFoe, against his History of the union. Edinburgh, printed by the heirs and successors of Andrew Anderson, printer to the Queens most excellent majesty. $1708.4^{\circ} ; 1-8 \mathrm{pp}$. (DANIEL DefoE.) E, O, LU-G, CtY

This defense of Daniel Defoe sought to prove that the author of No. 162 had not only tried in every way to make his account of the union as correct as possible, but also to verify his account. The author took Mr. Clark's objections and answered them one by one. Since they were differences of fact as much as of interpretation, they turned upon the memory of the men directly involved. Interestingly, Clark's objections apparently were based upon a reading of the book before it was actually available to the public. The debate between Defoe and Clark was: Nos. 162, 283, 311, 28, 182, 336, 17.

29 An answer to my Lord Beilhaven's second speech, demonstrating the advantages that will ensue to both nations by the union, \&c. [1706, after 15 November]. $4^{\circ} ; 1-4 \mathrm{pp}$.

$\mathrm{CtY}$

Belhaven's aversion to an incorporating union was well-known prior to the specch referred to, and this answer to the speech sought to refute his arguments in much the same style as that of Belhaven himself. The overall theme was that a union would be of concrete advantage to Scotland, and that resistance to it was illogical and not in Scotland's best interest. This was an answer to No. 239.

30 An answer to my Lord Beilhaven's speech. By an English gentleman. [London]. 1706 (ca. 18 November). $8^{\circ}$; 1-2 3-16 pp. (Daniel Defoe.) L, E, O, LU-G, CtY, InU

Belhaven's speech provoked numerous reactions (two of them being Nos. 398 and 151); this one attributed to Defoe sought to prove that Belhaven had not rationally proven his case. Belhaven had asserted that the Church of Scotland was in danger; Defoc denied this. If Scotland had her military victories, she also had her military defeats. Belhaven argued that Scottish trade would suffer; Defoc asked in what way. Again and again Belhaven was shown to be irrational in his assertions and rash in his conclusions. And yet, Defoe had to deal with a powerful speech by a past master at emotional appeal. The sequence of this controversy was: Nos. $241,30,525,355,332,374,118$.

31 An answer to some queries, \&cc. relative to the union: in a conference betwixt a coffee-master, and a countrey-farmer. [Edinburgh]. 1706. $4^{\circ} ; 12-12$ pp. L, CtY, DFo, $\mathrm{MH}$

This reply to Some Queries (No. 419) had as its objectives the refuting of those ques- 
tions and the advancing of the union in Scotland. The author asserted that the Parliament indeed was not bound by the National Covenant; that English law no more applied to Scotland after the union than Scottish law applied to England; and that Scotland's laws, religion, and people were as safe as or safer than before the union. It was a positive affirmation of the union, couched in a popular fashion to reach the public at large.

32 An answer to the brief account of the elections in the north of Britain. With some account of the new division there. London: printed for A. Baldwin, near the Oxford-Arms in Warwick-Lane. 1708 (HWL, November). $4^{\circ}$; (i-iv) 1-20 pp. $\mathrm{L}, \mathrm{E}, \mathrm{O}, \mathrm{CtY}, \mathrm{MH}$

If the Brief Account (No. 45) purported to be a patriotic expose of the corruption of the Squadrone and its illegal and scandalous actions before and after the union, this reply would have none of it. Rather, the author of the Account was held to be a hireling who published that work in London and Edinburgh for purely political reasons, predominantly to discredit the Squadrone with the whigs and tories in England. This author saw the Squadrone as acting out of the best interest of Scotland (though deploring the continuation of now artificial national distinctions); it was the Squadrone which had sought to protect all in North Britain against continuation of the despotic power of the Privy Council of Scotland. In conclusion, the author held up for examination the recent elections in the shire of Fife as an example of truly corrupt elections.

An answer to the letter from a commoner of North-Britain, by his friend in Edinburgh, with respect to Mr. Greenshield's case. Edinburgh, printed by James Watson, and sold at his shop, next door to the Red-Lyon, oposite to the Lucken-Booths. $1711.4^{\circ} ; 1-8$ pp. E

This "answer" to No. 56 gave additional support to those who were behind the bill for a toleration to the Episcopalians in Scotland. It presented the case for the Episcopalians as sincere Christians and loyal subjects who never had supported nor ever would support disorder, and who suffered gravely without recourse to violent retribution. The case of Mr. Greenshields, an Episcopal minister arrested in Edinburgh for holding services there, was the example utilized. While the work should be taken at face value, there is a light clement of the tongue-in-cheek here.

34 An answer to the Lord Haversham's speech, which he made in the House of Peers, on Saturday, February. 15, 1707. Concerning the union. London. $1707.4^{\circ} ; 12-4$ pp. L

[variant:] lacking "Concerning the union." [Edinburgh?]. 1706/7. $12^{\circ}$; both sides.

$\mathrm{E}$

Haversham's reputation for sensational speeches, as well as his well-known position, no doubt influenced this author to give moderate and brief treatment to the points raised by that nobleman in the House of Lords. The author did little more than deny that the Church of Scotland was in danger, and reaffirm the complicity of the Scottish peers and commoners in the settlement of their representation in the new Parliament. So many of these issues had been answered so many times before, and positions already were so fixed, that a more elaborate response might have been thought unnecessary and unwise. The speech (No. 242) also was answered in Nos. 256 and 328. 
An answer to the second letter to the Right Reverend, the Lord Bishop of Carlile, occasioned by some passages in his late book of The Scotch Library. Addressed to the same Bishop. Wherein, the Scots ancient possession in Britain, is asserted; and answers are given to the objections against it, in the second letter, and in Mr. Atwood's late book; and our authors are vindicated. Edinburgh, printed and sold by Mr. Andrew Symson. 1704 (dated 6 June). $4^{\circ}$; 1-2 3-104 (insert) 105-112 pp. (Robert Sibbald.) E, DFo

By 1704 the debate in the world of the historian and antiguarian was no less intense than the debate in the parliaments of England and Scotland over the relationship of those two kingdoms. In this work Sibbald sought to define and to refute allegations made by Rymer and others as to the dependency of the church and state of Scotland on England, and the nature of the historical relationship of England, Scotland, and France. In particular the place of the Episcopal church of Scotland was given special attention. The arguments were arid and the prose deadly, but the issues were of the greatest importance to the debate in progress. The sequence of the debate was: Nos. $362,235,482,236,156,450,35,188,160$, $81,451,483,238,519,422$.

36 An apology for the letter from Scotland against the Sacramental Test. London, printed for B. Bragge at the Raven in Pater-Noster-Row. 1708 (dated 16 December). $4^{\circ}$; $1-8$ pp. ("C.H."; sometimes attributed to Charles Leslie although content makes that attribution highly unlikely). E, O, CtY

The Letier (No. 199) caused quite a stir among those Anglicans in England who felt the Sacrametnal Test was a necessary safeguard for their church and state. The author sought to vindicate his position and to restate his ideas in such a way as to avoid antagonizing those high churchmen. This vindication restated the plea for religious toleration in matters political, but with little success in the highly charged atmosphere.

An appeal of the clergy of the Church of England to my lords the bishops; humbly besceching them to move Her most Sacred Majesty to redress their grievances. With some reflections upon the Presbyterian eloquence of John Tutchin and Daniel Foe, in their weekly Observators and Reviews. To which is annexed, as a postscript, the case of the Curate of Stepney, fairly and truly stated, and cleared from the vile aspersions of John Tutchin in the Obscrvator, Apr. 13. 1706. Vol. 5. N. 8. . . Part I . . By a Presbyter of the Church of England. London: printed by E. P. for R. Wilkin at the King's Head in St Paul's Church-Yard. 1706 (dated 1 May). $4^{\circ}$; 1-6 7-32 pp. (IsAAC ShaRp.) L, InU

This was an attack upon Defoc, Tutchin, and the dissenting press in general. It defended the Anglican clergy, as well as the Episcopal clergy of Scotland, against attacks upon their virtue and ideology. It is of particular interest for its defense of the collection of moneys by the Anglican clergy for their Episcopal colleagues in the north.

38 An appeal of the clergy of the Church of England to my lords the bishops; humbly beseeching them to move Her most Sacred Majesty to redress their grievances. Part II. With some reflections on the scandalous club, authors 
of the Observator revived. To which is added, a defence of the first part of the appeal; as also, a vindication of the collcction for the Episcopal clergy of Scotland. ... London: printed for R. Wilkin, at the King's Head in St. Paul's Church-Yard. 1708 (dated 15 December 1707). $4^{\circ}$; (i-xviii) 1-20 21-22 blk. pp. IsaAc Sharp. $\mathrm{E}$

Isaac Sharp, the author of this diatribe, defended the reputation of those in England who had collected for the Episcopal clergy of Scotland. Sharp was not one to spare the sensitivities of those who had attacked that collection, and this work was more of a tirade against Defoe, Tutchin, and others, than a reasonable defense of his own actions.

39 Atalantis Major. Printed in Olreeky, the chief city of the north part of Atalantis Major [Edinburgh]. 1711 (between 11 January and 13 February). $8^{\circ}$; (i-ii) 1-46 pp. (Daniel Defoe, but see Healey, p. 307.) L, E, O, Cty, InU, $\mathrm{MH}$

From internal evidence, this pamphlet was written and published by Defoe between 11 January 1711-when the Duke of Argyll was appointed commander-in-chief of the English forces in Spain-and 13 Fcbruary 1711-by which time Defoe had returned to England. Without doubt the objective of the pamphlct was to expose and ridicule Argyll, whose ambitions made him an unreliable ally. Thus Harley, who empioyed Defoe, would not have objected to an exposé of Argyll's activities in Scotland during the November election of peers.

40 The author of the Lawful prejudices against an incorporating union with England, defended. In answer to a pamphlet entituled, The dissenters in England vindicated, from some reflexions, in a late pamphlet entituled; Lawful prejudices \&c. Edinburgh. 1707 (between 17 January and 13 February 1706/7). $4^{\circ}$; (i-ii) 1-14 pp. (James Webster.) L, O, LU-G, CtY, DFo, MH

Webster was convinced that the Presbytcrian Church of Scotland stood alone, surrounded not only by Episcopalians in Scotland who wcre out to disestablish it, but also by Presbyterians in England who had become so accustomed to toleration and to cooperation with prelacy that they also were enemies to the true church. In particular, Webster feared that the dissenters in England, in alliance with the Episcopalians and the Anglicans, would force a toleration upon the Scottish Presbyterians. It was an ill-tempered paper, filled with doubts and suspicions. The first pamphlet in this debate was Webster's No. 187, which Defoc had answered in No. 109. It was to this pamphlet, as well as to Defoe's No. 499, that Webster addressed this work. Defoe once again answered him in No. 286.

41 The Bishop of Oxford's speech in the House of Peers in answer to several speeches made by the Lord Haversham, and others. Against the union. Dublin, printed by C. Carter at the sign of the Post-Office Printing-House in Fish-Shamble Street. 1707. $4^{\circ}$; $1-23-8$ pp. William Talbot. InU

[variant:] . . . in the House of Lords, March, 1706/7. London, printed for A. Baldwin in Warwick-Lane. 1710 (ca. 4 July). $2^{\circ}$; 1-4 pp. L, E, O, MH

Talbot was no man to be trifled with, and in this speech he plainly was angered at charges 
levelled against the bishops that they were lukewarm for Anglicanism or that they were against further security for the Church of England. Talbot cloquently and yet sternly reproached those high tories who had castigated him, and affirmed his support of the union, of 1688, and of the various settlements including that between the Churches of England and Scotland. He did not share the view of some tory members that Scotland and Presbyterianism were moving to the south bent on conquest.

42

The blessed union: or, a sermon preached on Psalm 133.1. On the first day of May, 1707. Being the thanksgiving-day, appointed by Her Majesty's special command. For the wonderful, and happy conclusion, of the Treaty, for the Union of Her Majesty's two kingdoms, of England and Scotland, \& London, printed for A. and J. Churchill, and sold by Hen. Truelove, Jun. bookseller in Ipswich. $1707.4^{\circ}$; 1-4 5-32 pp. Richard Enock.

This windy, high-flown scrmon rarely if at all departed from an examination of the scripture, and the historical Biblical background of the text. It was a scholarly sermon which did not stray from what was safe and obvious.

43

The blessedness of union. In a sermon preach'd upon the first day of May, 1707. At the Parish-Church of Thistleworth in Middlesex, being a day of thanksgiving for the happy union between England and Scotland. London: printed for William Hawes, at the Bible and Rose in Ludgate-street. 1707 (ca. 3 May). $8^{\circ}$; $12-16$ pp. Charles Williams. L, O, CtY, InU, KU

This minister was not particularly interested in the union or in Scotland, and indeed devoted little time to them. He did praise Anne and her bounty to the established church, and sought from her further benefits for the lesser clergy, who were his primary concern.

44 The blessings of the sixth year. A sermon preach'd before the Queen at St. James's Chappel, on Saturday the eighth of March, 1706/7. . . Publish'd by Her Majesty's special command. London: printed for A. and J. Churchill at the Black Swan in Pater-noster-row. 1707. $4^{\circ}$; $(i-i v) 1-28$ pp. William Nicolson. L, O, InU, KU

The second edition. London: printed and sold by $\mathrm{H}$. Hills in the Black-fryars, near the Water-side. For the benefit of the poor. $1707.8^{\circ} ; 12-16$ pp. L, E, O

[variant:] ... A sermon preach'd before the Queen at St. James's Chappel, on her inauguration day, two days after passing the Union Act. . . Publish'd by Her Majesty's special command. Edinburgh, re-printed by the heirs and successors of Andrew Anderson, printers to the Queens most Excellent Majesty. 1707. $4^{\circ}$; 1-3 4-12 pp. L, E

Nicolson preached before the Queen on the anniversary of her accession, just two days after the passing of the Act of Union. He came to the union only in conclusion, when he stressed relief from uncertainty and from border warfare, and urged a nation of all men in one kingdom benevolently governed by Anne, to whom he gave credit for bringing about the union. 
A brief account of the elections in the north of Britain; with some account of the new divisions there. Edinburgh, printed by the heirs and successors of Andrew Anderson, printer to the Queens most Excellent Majesty. 1708 (perhaps early July). $4^{\circ}$; $1-8$ pp. (GEorge Moncreiff.)

$$
\text { [London. 1708]. } 4^{\circ} ; 1-8 \text { pp. E, CtY }
$$

This in essence was a description of the elections in Scotland in May, 1708. The author obviously was against the Squadrone, whom he accused of being without principles and interested solely in getting or retaining offices and places in the Parliament. It was a bitter and harsh criticism of Scotsmen, their principles, and their actions, and one which the author (himself a Scot) regretted. To the extent that the author obviously was a man of political interests as well, this would be counted a political tract; but it is an interesting examination of the elections also. This was answered in No. 32. See also No, 517.

A brief view of the late Scots ministry. SEE: No. 517.

46 Brit. Ann. I. A Sermon preach'd on the thanksgiving-day, for the happy union of Great Britain. Under Her Sacred Majesty Queen Anne, May the 1st, 1707. London: printed by R. Tookey for the author. $1707.4^{\circ}$; (i-viii) 1-22 pp. Robert Davidson. L

This Anglican clergyman was most anxious to avoid controversy, and his sermon was moderate and innocuous. He urged loyalty to the Queen, and stressed Anne's support of the union. He saw the Scots as estimable as a people, and felt that there was little national difference between them and the English.

47 Britain in hazard of bondage. Representing, how dangerous it is for Protestants to have a Papist to rule over them. The dismal aspect of Providence at this critical juncture, should be alarming to all true Protestants, to take under serious consideration the eminent danger, their religion is in; especially in Britain and Ireland. [1712?]. $4^{\circ} ; 12-8 \mathrm{pp}$. L

This pamphlet on one level was nothing more than the usual diatribe against Papists and Jacobites; but it also was an attempt to persuade the Presbyterians (who balked at the Oath of Abjuration) that the Pretender was a Catholic, and that past experience did little to reassure those who feared the rule of such a prince over a Protestant kingdom. On that level, it was part of the attempt to soothe the Presbyterians distressed by the legislation of early 1712 .

48 Britannia. Anna's glory: or the happy union. A poem. Humbly dedicated to the Right Worshipful William Cooke, Esq; Mayor. Norwich: printed in Magdalen-street by the author. 1707 (ca. 1 May). $2^{\circ} ; 12-4$ pp. HenrY Cross-Grove.

This poem in praise of union might more aptly be described as a panegyric to Anne herself. Respect for Anne was more evident than affection for the union, but Cross-Grove glorified both in turn. It is indifferent poetry at best. 
In three parts. Edinburgh, printed by the heirs and successors of Andrew Anderson, printer to the Queen's most Excellent Majesty. 1706 (Moore; Foxon, early December $) .2^{\circ} ;(i-x)$ 1-60 pp. Daniel Defoe. L, E, O, CtY, InU, $\mathrm{MH}$

[variant:] Caledonia. A poem in honour of Scotland, and the Scots nation. In three parts. London: printed by J. Matthews, and sold by John Morphew, near Stationers-Hall. 1707 (ca. 28 January). $8^{\circ}$; (i-viii) $1-5556$ pp. L, E, O, $\mathrm{CtY}, \mathrm{MH}$

This laudatory poem in praise of Scotland past, present, and future, was written by Defoe in part to soothe the Scots, who in late 1706 were by no means unanimous for union, and were decidedly uneasy about the future of their kingdom. Defoc not only praised their past exploits, but flattered them with his attention to their economic possibilities, with or without union. Undoubtedly Defoe did not forget that England also was less than completely in support of the union, and if praisc given to Scotland cncouraged the English to think more highly of the Scots, he would not have becn displeased.

50 Calidonia Rediviva: or, the Scotch riddle. Being a new description of a port in North Britain. London; printed, and sold by J. Baker, at the Black Boy in Pater-Noster-Row. 1711. $8^{\circ}$; 1-2 3-16 pp.

$\mathrm{E}$

This rather bawdy verse satire of some of the more usual types of Scotsmen is typical of a common English attitude, and is similar to the descriptions of Scotland which attempted to construct a more realistic visit than this imaginary one.

51 Captain Green's last conference with Captain Madder, his first mate, in the Tolbooth of Edinburgh. . . . Edinburgh, printed by James Watson. 1705. $4^{\circ} ; 1-23-8 \mathrm{pp}$. $\mathrm{E}$

The Scots were not reluctant to write about Captain Green; this poem took him to task for piracy, and censured Madder for betraying his native country. Both men had been tried in Scotland for piracy against a Scottish ship, found guilty, and-despite vehemeat English protest-executed. In this work the author gave the overall impression that both men deserved their fates.

52 Captain Thomas Green's last farewell to the ocean and all the world, who was execute with two more of his crew at Leith within the Flood-Mark, 11 April 1705, for piracie and murder. Edinburgh, printed by G. J. [George Jaffray]. $1705.1 / 2^{\circ}$; one side. E

This bit of doggerel attempted to present to the world the last farewell of Captain Green, an Englishman executed in Scotland for piracy. Green, as captain of the Worcester, had been found guilty - in a Scottish court-of piracy against a Scottish ship and had been executed in due course. The intent of the author was to restate the claim that Green was innocent of the crimes.

53 Carmen Irenicum. The union of the imperial crowns of Great Britain. An heroick poem. London, printed for the author. $1707.2^{\circ} ; 1.78-4748 \mathrm{pp}$. 
[Title and text printed in Latin on verso of each leaf, opposite to English text]. (Elxanah Setrle). L, E, O, CtY, MH

MH

. Date changed to MDCVIII by inking another I into the period. . London, printed by J. Brudenell in Little-Britain, for the author. 1707. $2^{\circ} ; 1-78-4748 \mathrm{pp}$. L, InU, MH

MH

This long and laudatory poem in praise of Anne and the union was typical of Settle, whose indifferent verse marked many a celebration.

54 The case of Capt. Tho. Green, Commander of the ship Worcester, and his crew, tried and condemned for pyracy \& murther, in the High Court of Admiralty of Scotland. London: printed, and are to be sold by John Nutt near Stationers-Hall. 1705 (HWL, April). $4^{\circ}$; 1-3 4-5 $87-30$ pp. L, E, O

$$
\text { 1-3 4-7 87-30 pp. E, DFo, InU }
$$

In 1705 the tension between English and Scots mounted, as the Scots tried Captain Green--an Englishman-for piracy against a Scottish ship and executed him and his first mate. This pamphlet was more of a compilation of documents in the case, and in particular the depositions supposedly given by thosc involved, than an analysis. It was not an official document, nor did it comment in any detail upon the documents reprinted. However the charge was made at the time that the documents were not delivered to the judge in Edinburgh, but rather were printed at London as though they were part of the official trial. The overall effect would have been to inflame English opinion against Scots justice. See also No. 274.

55 The case of Mr. Greenshields, as it was printed in London, with remarks upon the same; and copies of the original papers relating to that affair: as also a list of the late Episcopal ministers, who enjoy churches or legal benefices in Scotland. Edinburgh, reprinted by the heirs and successors of Andrew Anderson printer to the Queens most Excellent Majesty. 1710 (before November). $4^{\circ} ;(i-i v) 1-60$ pp. L, E, KU

This rather strange pamphlet combined two separate bodies of material, for and against the Rev. James Greenshields, the Episcopal minister arrested in Edinburgh. The first half of the work consisted of documents and depositions by Greenshields and others relative to the case. The latter section was an attack upon Greenshields and the Episcopalians, and a refutation of his defence of charges brought against him. Of greatest interest is the list of Episcopal ministers in Scotland in 1710.

56 The case of Mr. Greenshields, fully stated and discuss'd, in a letter from a commoner of North Britain to an English peer. London. 1711 (Arber, Easter). $4^{\circ}$; 1-2 3-23 24 pp. (George LockHART, although sometimes attributed to James Lyon). L, E, O, CtY, MH, KU 
London, re-printed. nd. $16^{\circ} ; 32 \mathrm{pp}$.

$\mathrm{MH}$ note, at this date, copy mislaid.

The arrest of Greenshields in Edinburgh for holding public services for those of the Episcopal faith aroused a considerable furor in Scotland and in England. The appeal of the case from the Scuttish courts to the British House of Lords brought the problem of the Episcopal ministers of Scotland before the Anglican-dominated Parliament, and even more directly to the attention of Anglicans in England. This tract presented the background of the case, from an Episcopal or Anglican point of vicw, to the Lords-and more important, to the appropriate parties in England. It was a presentation which would not have met with the approval of the Preshyterians in Scotand, either in tone or in content. This tract was answered in Nos. 33 and 227.

57 The case of Mr. James Greenshields. As it was given in to the Right Honourable the House of Lords. [Edinburgh? 1710?] (Bib. Linds., May?). $1 / 2^{\circ} ; 1-2 \mathrm{pp}$. $\mathrm{E}$

This brief statement of the case of Mr. Greenshields prescnted the bare outlines of the life and history of this Episcopal minister in Edinburgh and the actions brought against him there for using the English service. It is of value primarily for its biographical information and as a summary of the case as it was stated when appcalcd to the Lords.

58 The case of Scots-Men residing in England and in the English plantations. Containing an account of the reasons in law, why they look upon themselves as entituled to all the priviledges of the natives of England. Of the diffculties they labour under, by a new construction of some late acts of Parliament: with instances upon that head. And of their reasons, why they think they are not excluded from the priviledges of English-Men by those acts: and that it is not the interest of England, they should be so. Design'd to have been offer'd to the consideration of both Houses of Parliament in England the last session, but prevented by the Treaty appointed for the Union of both kingdoms. Edinburgh. Re-printed 1703. (No earlier edition has been located). $4^{\circ}$; 1-2 3-14 15-16 blk.pp. (GEORGe Ridpat'H.) E, LU-G, CtY, InU

By 1703 Anglo-Scottish relations were so strained that Scotsmen living in England or in English colonies felt threatened in matters of law, where they often werc treated as aliens. This author repeated those charges against the English, and argued that such discrimination, applied primarily to Scots in trade or those seeking public office, was not only in violation of the laws of England, but also against the best interest of England as well. The number of Scots residing in the colonics was held to be considerable; if they were forced to flec, they would deprive the colonies of manpower, of trade and industry, and of population. The overall tone was one of admonition, not threats, toward England.

59 The case of several merchants and others, concerned in the fishery of North-Britain. [London]. 1711. $12^{\circ} ; 1-2$ pp. L, E, LU-G, MH

The difficulty in securing an adequate supply of quality salt for the curing of fish was compounded in 1711 by the war, and by the seizure of a large quantity of Portugese and 
Spanish salt in Scotland, which, by order of Parliament, was taken up, auctioned, and ordered sold for export soon after the union. The need for this salt encouraged this petition which sought the release of the unsold salt for use in Scotland in the curing of fish, which otherwise would be lost.

60 The case of the Church of Scotland with relation to the bill for a toleration to the Episcopal dissenters to set up meeting-houses, and use the English service in Scotland. [London. 1712] (Kennett, between 21 and 30 January). $2^{\circ}$; 1-4 pp. (William Carstares.) L, E, O

The determination of the high Anglican, tory majority within the government and Parliament after 1710, to advance the interests of the Episcopalians in Scotland and to provide for a toleration for them, violated what most Presbyterians in Scotland felt to be the spirit and the letter of the Act of Union. This legalistic paper sought to show members of the Parliament exactly how that bill did violate the terms of the Act of Union, and in what ways it undermined the authority of the Church of Scotland and its members in the interest of a disestablished minority, and often disloyal religious element. The legal argument was most exact and correct. Other tracts in this controversy included: Nos. 363, 418, 413 , and 91 .

61 The case of the collections in England for the distressed Episcopal clergy of Scotla[nd-_-_(paper torn) - - ] first rise truly and briefly represented. [London. 1711]. $12^{\circ} ; 1-2$ pp. E

The plight of the Episcopal clergy in Scotland undoubtedly was a hard one after 1688, and time did not diminish the needs of many unable to adjust. This paper attempted to recount the history of that clergy since 1688, and to show what financial difficulties they labored under in Scotland; the author also sought to justify the activities of those supervising the collecting and disbursing of funds raised to assist these men, and in particular to refute charges that the moneys were granted only to clergymen who adhered to correct political opinions. In conclusion, Defoe and the Review were cited as evidence of support for these funds even from a source as distasteful to the Episcopalians as was that writer.

62 The case of the Episcopal clergy of Scotland truly represented. London. 1707 (dated 20 March 1706). $2^{\circ} ; 1-4$ pp. E, O, DFo

[another edition]. London. 1707 (dated 20 March 1706). $2^{\circ} ; 1-4 \mathrm{pp}$. E - London. 1707 (dated 20 March 1706). $2^{\circ} ; 1234$ pp. DFo . London. 1707 (not dated). $2^{\circ} ; 1-4$ pp. DFo

This highly emotional account of the plight of the Episcopal clergy in Scotland during and after 1688 was certain to arouse considerable sympathy in England where their religious counterparts were the Anglicans. In Scotland as well, the Episcopalians were in sufficient numbers to harass the Presbyterians, who in turn felt compelled to respond with vigor. With union much in the air, this issue had great emotional impact in both kingdoms. The case of the exporters of fish from Scotland. [1709?]. $12^{\circ}$; one side. $\quad \mathrm{E}, \mathrm{LU}-\mathrm{G}, \mathrm{MH}$

In the early eighteenth century in Scotland, fish and the fishing industry were of primary 
importance. Union with England had not resolved, but rather had complicated the industry's problems, which were dealt with in slight detail in this work. No. 99 was written as an answer to this.

64 The case of the exporters of herrings and other fish, and of beef and pork from Scotland, since the 1st of May, 1707. [Edinburgh? 1709/1710]. $2^{\circ}$; 1-4 pp. L, LU.G

At the time of the union the fishing industries of. England and Scotland differed in most respects. From the type of fish caught to the way in which it was cured and the place where it was sold, the two industrics operated on different bases. These differences, evident in such things as the salt used to cure fish and the subsidies given to assist the industry, supposedly were dealt with in the Treaty of Union; but the precise details and implemen. tation of the schemes provided werc left to be settled thereafter. This tract was concerned with the feeling by the Scots that they had been denied their just rights under the Treaty of Union insofar as fishing rebates and other matters were concerned.

65 The case of the land-officers who went in the service of the Indian and African Company, on their first expedition to Caledonia. Humbly offered to the consideration of the Right Honourable Committee of Parliament, to whom it is referred to adjust the said Company's quota of the equivalent, \&c. [Edinburgh]. 1707. $2^{\circ} ; 12-34 \mathrm{pp}$. E

The equivalent was supposedly to be used in part to repay investors in the Company of Scotland. Those officers who had gone to Darien on the first expedition sought part of that equivalent on the grounds that they had been promised that whatever part of the original subscription was not sold would be invested in the company in their behalf. They therefore claimed compensation.

66 The casc of the late Indian and African Company of Scotland, with other part-owners of the ships Speedwell and Annandale trading to India. [London? 1711]. $12^{\circ}$; one side. E, LU.G

[variant:] ... with other part owners... $12^{\circ}$; one side.

O

This petition with reference to the Speedwell and the Annandale concluded the controversy over the Scots East India Company.

67 Case of the owners and freighters of the ship Worcester and cargoe, seized and condemned in Scotland. London. 1706 (dated 10 August). $12^{\circ}$; one side. LLI

This petition sought from the Queen redress of grievances for losses suffered by the owners and freighters of the Worcester. This ship, captained by Thomas Green, had been seized and sold in Scotland, and Green and his first mate had been tried and exccuted for piracy. This case aroused considerable controversy in England, where Green and his men were held to have been unjustly accused and unfairly tried and executed.

68 The case of the owners and freighters of the ship Worcester, in relation to the seising and condemning of the said ship and cargoe; in the High Court 
of Admiralty in Scotland; for reprisal of the Scots ship Annandale, seised by the English East-India Company in England. And also the case of the late Capt. Thomas Green, commander of the said ship Worcester, and his crew, condemned and part of them executed in Scotland, for pretended piracy and murder. London. 1705 (after 7 May). 4 ; 1-2 3-127 128 pp. DFo

The case of Captain Green and the Worcester was one of the most controversial affairs of 1705 , and one which rubbed raw Anglo-Scottish relations. This presentation of materials drawn from the trial in Scotland and from other sources relative to the seizure of the ship and the trial of Green for piracy was written from the point of view of the owners of the Worcester and the defenders of Green, but included much valuable material. This would have to be counted among the more important works in any study of the affair.

69 The case of the owners and freighters of the ship Worcester, seiz'd in Scotland. [1708]. $1 / 2^{\circ}$; one side. L

Compensation due the owners of the Worcester, seized by the Scots, was slow in coming. The Worcester had been sold in Scotland and its captain and first mate tried and executed for piracy against Scottish ships. This petition sought to secure for the owners moneys allocated to them but not paid, and, at the time of this petition, endangered by changes in the laws relating to prize moneys.

70 The case of the ship Annandale, belonging to the Company of Scotland, trading to Affrica and the Indies. [Edinburgh. 1704]. $12^{\circ}$; one side. $\quad \mathrm{E}, \mathrm{O}$

The dispatch of the Annandale to take off the goods of the Scots East India Company from their ship wrecked in the Straits of Malacca did not succeed. The English East India Company objected to her departure from London on the grounds that Englishmen had a stake in her and that it therefore violated their monopoly. This paper sought to reason with that English company and to clarify the situation just before the departure of the Annandale. Only a few days later she was to be seized on behalf of the English East India Company.

71 The case of the traders and poor people imployed and maintained in the linnen manufacture in North Britain, relating to the present and further duty intended to be laid upon Scots linnen, \&c. Humbly offered to the Honourable House of Commons. [1714] (before August). $12^{\circ}$; one side. LU-G

Taxes placed upon the linen industry, which was particularly strong in Scotland, were so destructive that the collapse of the industry was predicted. This case sought to put the plight of the linen manufacturers of Scotland before the House of Commons.

72 The case of Tho. Bowrey, Tho. Hammond, John Starke, and divers others the owners and freighters of the ship Worcester; Capt. Tho. Green late commander, seiz'd and condemn'd in Scotland. [1705/1707]. 1/2 ${ }^{\circ}$; one side. LLI

The seizure of the Company of Scotland's Annandale in English waters provoked the Scots to retaliate with the seizure of the Worcester in Scottish waters. It was from this latter 
action in Scotland that the case of Captain Green and his crew originated, for rumors of piracy had begun to circulate in Edinburgh shortly afterwards. This petition sought redress for losses by the owners and freighters of the Worcester.

73 The causes of the decay of Presbytery in Scotland. In answer to a letter from a clergy-man of that perswasion.... London, printed for, and sold by John Morphew near Stationers-Hall. 1713 (between May and September). $8^{\circ} ;(i-i i) 1-46$ pp. L, E, O

… Edinburgh. 1713. $8^{\circ}$; (i-ii) 1-44 pp. L (lacking pp. 41-44), DFo

This pamphlet was published before the elections of 1713; it tends to confuse more than to clarify matters in Scotland. Written from an Episcopalian point of view but from an English as opposed to a Scottish angle, it was a complicated review of the distant and recent political past of Scotland, with considerable attention to religious matters. The author sought the defeat of any surviving members of the Squadrone, and the election of men of a high tory sentiment. The malt tax, the religion of the Hanoverians, the Greenshields case, the union, and other controversial issues all were raised in such a way as to provoke the electors.

[A caveat against the whiggs. In a short historical view of their tranactions(!). Wherein are discover'd their many attempts and contrivances against the establish'd government both in church and state, since the restoration of King Charles II.... ]

74 A third part of the caveat against the whiggs, in a short historical account of their transactions since the revolution.... London: printed and sold by J. Morphew near Stationer's-Hall. 1712. $8^{\circ}$; (i-iv) 1-108 pp. (Chart,es HORNBY.) $\mathrm{O}, \mathrm{MH}$

Second edition. London: printed \& sold by $J$. Morphew near Stationer's-Hall. 1712. $8^{\circ}$; (i-iv) 1-108 pp. L (lacking i-ii), CtY, KU (lacking i-ii)

[variant, second cdition:] A third part... E E

. The third edition. London: printed and sold by J. Morphew near Stationer's-Hall. 1714 (ca. 16 March). $8^{\circ}$; (i-iv) 1-108 pp.

$\mathrm{O}$

This four-part narrative traced the political development of Britain from the reign of Charles II through that of Anne. For the most part, the focus was on England with brief: excursions into Irish or Scottish history only as they forced consideration of themselves on England. Therefore the first two parts, which comment on Scotland from time to time, lack any sustained interest in her. The third part, however, is included here for its treatment of Glencoe, which gives a view sympathetic to the Macdonalds. Throughout, the author held to a tory stance which became most pronounced when dealing with William III or with the Presbyterians of Scotland.

75 The fourth and last part of a caveat against the whiggs, \&c. In a short historical account of their behaviour in the reign of Her Majesty Queen 
Anne. ... London: printed, and sold by J. Morphew, near Stationers-Hall. 1712 (possibly for 1713 ). $8^{\circ}$; (i-iv) 1-130 131-132 pp. (Charles Hornby.) $\mathrm{MH}$ (lacking $i$-ii), $\mathrm{KU}$

. The second edition. London: printed, and sold by J. Morphew, near Stationers-Hall. 1712 (possibly for 1713). $8^{\circ}$; (i-ii) 1-130 131-132 pp.

L, E, O, CtY

This part of the Caveat was not particularly concerned with Scotland, but it did deal with Scotland as part of the overall reign of Queen Anne. The Presbyterians there as well as those who had supported William III were not held in high csteem; but the problem for the tory writer of this pamphlet was how to recognize Anne's support for the union while at the same time dealing severely with the Presbyterians of Scotland, who were so disliked by the tories. It was an interesting account of the reign of Anne, as seen from a tory viewpoint.

76 The Church of England - [still persecuted] or the case of Mr. Murray, depos'd by the presbytry of Perth, on the 10th of January, for reading the English service. [Edinburgh?]. 1712 (between 10 January and 22 February, when the bill for a toleration in Scotland passed the Lords). $12^{\circ}$; both sides. (The Rev. [Richard?] Dungworth.) E

[variant:] The Church of England still persecuted, or the case of Mr. Murray, depos'd by the presbytry of Perth, on the tenth of January, for reading the English service. nd. $2^{\circ} ; 1-34$ pp. E

The tory ministry had well in mind the best interest of both the Anglicans in England and the Episcopalians in Scotland; and in 1712 passage of a bill in favor of the latter group seemed increasingly certain. This pamphlet sought to provide more information against the Scots Presbyterians, and to recount not only the past difficulties of the Episcopalians but also to ensure that their present plight was known in England.

77 The circumstances of Scotland consider'd with respect to the present scarcity of money: together with some proposals for supplying the defect thereof, and rectifying the ballance of trade. Edinburgh, printed by James Watson. $1705.4^{\circ} ; 1-23-2726 \mathrm{pp}$. (Anonymous, but sometimes attributed to John Clerk.) L, E, LU-G, DFo, MH

The Scots were convinced that the prosperity of their country relative to other states had declined during the seventeenth century, and this author was no exception. He attempted to determine what really had happened and to indicate some measures which might have remedied the situation. The coinage, the state of trade, hoarding, excessive imports, as well as other factors, all were considered. Interestingly, the problem was not laid at England's door.

78 The clause proposed in the English Parliament to prevent the French goods being imported thro' Scotland; with a short remark on the same. Edinburgh. 1707 (April?). $12^{\circ}$; both sides. $\mathrm{E}$

Between January and May, 1707, foreign and Scottish merchants imported goods into 
Scotland at a lower tariff rate to await 1 May, when they could be carried into England, which had a higher rate. This angered the English merchants, who sought to prevent this maneuver. This writer pointed out to the Scots that the English House of Lords had rejected all legislation to penalize them, and admonished them to be thankful.

79 A collection of original papers about the Scots plot. Containing, besides what has been already publish'd, the following papers, never before printed: I. The Duke of Athol's memorial to her Majesty, read in the Scots Council at St. James's, Jan. 17. 1703/4. giving an account of the discovery of Capt. Simon Frazer and his accomplices. II. A letter in ciphers to Colin Campbel of Glenderoul, with a key. III. The examinations of Mr. George Bruce and Mr. George Graham, about the Lord Belhaven. With remarks upon the whole, and Cunningham of Montgrenan's declaration, on his death-bed, against several persons that would have suborn'd him to swear against the family of Hamilton. To which is added, Considerations upon the interest of both kingdoms, with relation to the settling of the succession in Scotland. London. 1704. (HWL, Junc). $4^{\circ}$; (i-viii) 1-64 1-5768-8788 pp. L, E, $\mathrm{O}, \mathrm{CtY}, \mathrm{DFo}, \mathrm{MH}$

The so-called "Scots Plot" was not predominantly Scottish in origin or in support. The men involved came from England and Scotland, and the sentiments motivating men to support the abortive uprising were varied and certainly not an exclusively anti-English affair. The degree to which Englishmen believed it to be more Scottish than English, however, was an aspect of Anglo-Scottish aftairs; therefore this collection of materials is included to present the case for and against those involved in that Jacobite plot.

A collection of original papers and material transactions. SEE: No. 162.

80 A collection of papers against the Scots toleration and patronages, that have been printed or presented to Her Majesty, and the two Houses of Parliament. To which is added, the Abjuration Oath, with an itroductory (!) letter, containing some remarks upon it. London: printed for Andrew Bell, at the Cross-Keys and Bible in Cornhill. 1712 (dated 4 April; HWL, JanuaryMarch; published ca. 5 May). $8^{\circ}$; 1-4 5-161-75 76 pp. L, E, DFo, InU

The Scots Presbyterians accepted the Acts of Tolcration and Patronage passed by the tory Parliament with extreme difficulty. The press was filled with cries for and against those acts and with attempts to persuade the Presbyterians that their church was not in danger. These papers purported to show that the Presbyterians were neither for the Pretender nor against the Hanoverians.

81 Collections concerning the Scottish history, preceeding the death of King David the First, in the year 1153. Wherein the soveraignity of the crown and independency of the church are cleared; and an account given of the antiquity and purity of the Scottish-British church, and the noveltie of Popery in this kingdom. With an appendix, containing the copies of charters of foundation of some churches; with genealogical accounts of the donors and 
witnesses. . . Edinburgh, printed by the heirs and successors of Andrew Anderson, printer to the Queen's most Excellent Majesty. 1705 (before 8 October). $8^{\circ}$ (turned chain lines, sig. A); (i-viii) I-LXXXVI LXXXVII-XC 1-432 433-436. James Dalrymple.

$\mathrm{L}, \mathrm{E}, \mathrm{DFo}, \mathrm{KU}$

[variant:] Edinburgh, printed by the heirs and successors of Andrew Anderson, printer to the Queen's most Excellent Majesty; and are to be sold by John Vallange and Mrs. Ogstoun book-sellers. L

As the title indicates, Dalrymple sought to refute charges made by Atwood, whose work was published after part of this collection was in the press. Dalrymple asserted the independency of the Church of Scotland and it was this-and Atwood's assertions that both church and state were dependent-which interested him. It was an attempt to prove that Scotland was historically independent of English influence and indeed possessed a purer church and state than did England. The sequence of the controversy was: Nos. 362, 235, $482,236,156,450,35,188,160,81,451,483,238,519,422$.

82 The comical history of the marriage betwixt Fergusia and Heptarchus. ... [Edinburgh]. 1706. $4^{\circ}$; 1-2 3-30 pp. (William Wright; sometimes attributed to John Bannatyne and to James. Webster.) L, E, LU-G, CtY [variant:] The comical history of the marriage-union betwixt Fergusia and Heptarchus. ... Printed in Scotland upon that occasion; and reprinted in England [London]. 1706. $4^{\circ}$; 1-2 3-32 pp. L, E, CtY, DFo (lacking 1-2), InU, $\mathrm{MH}$

This feeble attempt to present the history of England and Scotland in allegorical form does littlc more than convey the author's opposition to the union and his fears for the established church in Scotland. Lady Fergusia represents Scotland, who is handled most brutally and selfishly by the unpleasant Heptarchus, or England. It is heavy humor at best.

83 A complete key to the three parts of Law is a bottomless-pit, and the story of the St. Alban's ghost. . . 1712 (ca. 19 April). $8^{\circ}$; 1-2 3-8 pp. (WILliam Wagstaffe? ) L, E, O, DFo

. The second edition corrected. 1712 (ca. 29 April). $8^{\circ}$; 1-2 3-8

pp. O, CtY

The key was to the complete three parts of the lohn Bull series, and it simply identified the characters in those parts. See No. 181. Subsequent advertised editions of the key have not been located.

84 A confession and lamentation, recommended to Mr. Madder to subscribe before his death that thereby he may appease his countrey mens wrath thats hot against him for his unaccountable hardness. To the tune of, Captain Johnstons lament. [Edinburgh. 1705]. 1/2 ${ }^{\circ}$; one side.

$\mathrm{E}$

The seizure of the Worcester, an English ship forced into a Scottish port by bad weather, and the trial for piracy of Captain Green and his first mate, Madder, aroused the fury of the English, who claimed that Green and his men had been unjustly tried and executed 
in an emotional atmosphere in Edinburgh which precluded justice. The Scots, however, were enraged not only against Green but even more so against Mr. Madder, who was a native Scot. This was one of several short "confessions" which were sold as the last speeches of the executed men.

85 Considerations in relation to trade considered, and a short vicw of our present trade and taxes, compared with what these taxes may amount to after the union, \&c. Reviewed.... [Edinburgh?]. 1706 (Burch I, 14-23 November). $4^{\circ} ; 1-23-26$ pp. (Daniel Defoe?) E, LU-G, MH

The author of this tract wrote to refute two essays written by William Black (Nos. 408 and 412) on matters economic, and the impact of the union upon trade and industry in Scotland. This author attempted to show that the figures which Black used were inaccurate and badly applied, and that his conclusions relative to the effect of the English duty upon salt and the increased tax upon malt were unreliable or pessimistic. The overall view projected was one of increased prosperity with only slight and temporary adjustments necessary after the union. This pamphlet was answered by Black in No, 533. Defoe had answered the two earlier tracts in Nos. 138 and 193.

86 Considerations upon the union of the two kingdoms: with an account of the methods taken by ancient and modern governments, to effect an union, without endangering the fundamental constitutions of the united countries. ... [London]. 1706 (before mid-September). $8^{\circ}$; (i-ii) iii-vii viii $1-9394$ pp. (George Ridpath.) E, O, CtY, DFo, MH

This author opposed the union on the grounds that the articles proposed an abolition of the separate Parliaments of England and Scotland, and thus altered the fundamental constitution of Scotland. The sitting Parliament, he argued, could not ratify articles which in fact would abolish that same Parliament without recourse to an appeal to the electorate. Most important, however, was his opposition to one Parliament for all of Britain: such an arrangement would leave Scotland with no protection for her laws, liberties, religion, or trade. It was an extended tract which covered many of the objections to the union, but which concentrated upon the loss of Parliament as an essential reason for its rejection. This, like No. 340, was answered in No. 225.

87 A converse betwixt two Presbyterians of the established church an elder and a preacher. Wherein the Presbyterian dissenters from the establish'd church, are vindicate from the charge of Jacobitism; their principles anent civil government, are fairly stated, and succinctly proven consonant to Scripture light, and the Confession of Faith; and several important objections thereanent, answered. For confirmation of the weak, and information of the misinformed in that matter... 1714. $4^{\circ}$; 1-2 3-52 Pp. (Hugh Clark.) E

The more extreme Presbyterians were a difficult group to integrate into society and certainly did little to make accommodation easy. As Anne declined physically, the question of succession loomed larger. The more radical Presbyterians, who certainly did not care for a Catholic James III, also did not care for a possible Lutheran successor. Indeed much in the union and the succession went against their religious principles. Clark's con- 
cern was this split within the Presbyterians and the attitude toward it from outside the church.

88

A convincing reply to the Lord Beilhaven's speech, in relation to the pretended independency of the Scottish nation, from that of England; wherein it is prov'd by antient records, law, and history, that the Scots kings did acknowledge their subjection to the imperial crown of England, long before, and since, the conquest. London, printed and sold by B. Bragg, at the Raven in Pater-Noster-Row. 1707 (before 30 November 1706). $8^{\circ}$; (i-ii) 1-3 6-16 pp. E, O

The Scots proudly claimed sovereignty and a glorious past for Scotland, but not everyone agreed with them and their historians. This author purported to prove through an examination of the records of the Scottish church and state that Scotland was a tributary state and one with no claim to independence and sovcreignty. The evidence was not convincing as such, but it was an insult which the Scots would understand and resent. This was an answer to No. 241, as were No. 398 and 30, which sparked off the debate: Nos. 525, 355, $332,374,118$.

A copy of a letter anent a project, for erecting a library, in every presbytry, or at least county, in the Highlands: from a reverend minister of the Scots nation now in England, to a minister of Edinburgh. With reasons for it, and a schem for erecting and preserving these libraries. Edinburgh, printed by George Mosman. 1702. 4 ; 1-2 3-11 12 pp. (Jamis Kirkwood.) L, E, $\mathrm{DFo}, \mathrm{MH}$

Kirkwood was a minister who was genuinely interested in distributing Bibles and promoting knowledge in the Highlands of Scotland. This Anglo-Scottish project, which did not prosper, illustrates the enormous gap between the Highlands and Lowlands, and the "outside" attitude toward the Highlands and religious and political conditions there.

90 A copy of a letter from a country farmer to his laird, a Member of Parliament. [1706]. $4^{\circ}$; 1-4 pp. L, E

This protestation against the union is interesting primarily because of the (mocki) Scots in which it was written. The arguments were the usual ones, with the abandoning of the church and the liberty and sovereignty of Scotland among them; the language however, whether authentic or an attempt to give a popular air to the protest, would repay attention by anyone interested in the vernacular of Lowland Scotland.

91 The counter-queries, queried again. [1712]. 2 ${ }^{\circ} ; 1-4$ pp. (Anonymous, although formerly attributed to James Gray.)

The Presbyterians in Scotland were not without defenders, and this tract attempted to restate the Preshyterian position relative to the enforced toleration in Scotland. In essence, the problem revolved around the determination of the Anglican high tory party in the British Parliament to protect and to advance the Episcopal party in Scotland. That party undoubtedly had good examples of hardship and abuse of justice to back its pleas for a tolcration; but as this author asserted, the example being set by the Anglicans in behalf 
of a dissenting element and in violation of the Act of Union was a dangerous precedent. Other works on this subject included: Nos. 60, 363, 418, 413.

92 Counter quiries to the quiries burnt at the Cross of Edinburgh December 17 1706. which appear to be writ by some of Mr. Hepburns folowers, or some body personating them. [Edinburgh? 1706/1707]. $1 / 2^{\circ}$; one side.

\section{$\mathrm{L}, \mathrm{MH}$}

The more extreme Presbyterians did not support the union; indeed they considered it little less than an alliance with godless men. They protested the religious provisions of that Treaty of Union and proclaimed their protests in and out of Edinburgh. This reply to those assertions argued that such Presbytcrians were allied with the tories in an unlikely and dangerous collaboration, which in fact would endanger the religion even more than would a union.

93 The crisis or, a discourse representing, from the most authentick records, the just causes of the late happy revolution: and the several settlements of the crowns of England and Scotland on Her Majesty; and on the demise of Her Majesty without issue, upon the most illustrious Princess Sophia, Electress and Dutchess Dowager of Hanover, and the heirs of her body being Protestants; by previous acts of both Parliaments of the late kingdoms of England and Scotland; and confirmed by the Parliament of Great Britain. With some seasonable remarks on the danger of a Popish successor. London: printed by Sam. Buckley; and sold by Ferd. Burleigh, in Amen-Corner. 1713 (Davis \& Ehrenpreis; Aitken, 19 January 1714, but some dated 1713, o.s.; Kennett, 1 December 1713). $4^{\circ}$; (i-x) $12-3738$, advt. pp. Richard Steele.* L, DFo, InU

$$
\text { 1714. L, E, O, CtY }
$$

[variant:] The crisis: or, ... Popish successor. ... London: printed by Sam. Buckley; and sold by Ferd. Burleigh, in Amen-Corner. 1714. $4^{\circ}$; (I-II) i-vii viii $12-3738$ advt. pp. $\quad \mathrm{KU}$

[variant:] 1714 (ca. 15 February). (i-x) $12-37$ 38, advt. pp. [additional leaf:] "Appendix to what has been so fully and well said by the author, here is subjoined the opinion of the Covention of Estates in Scotland, in the following act subscribed in the meeting. March 16, 1689." $\mathrm{E}$

[variant:] The crisis: or, ... England and Scotland on Her Majesty: ... The second edition. [London] Printed by S. Buckly, and sold by F. Burleigh in Amen-Corner. 1714. (I-II) i ii iii-vii viii blk. $12-3839-40$ blk. pp. MH, $\mathrm{KU}$

[Pirated edition:] ... discourse representing the just causes . . body being Protestants. With remarks on the danger of a Popish successor. Abridg'd from that writ by Richard Steele, esq; London: Printed by J.Read near Fleetstreet. 1714 (Blanchard, 25 January). $4^{\circ} ; 12-24$ pp. TxU 
59-60 pp. O, KU

[variant of Edinburgh, re-printed:] (i-ii) iii-x 11 12-57 $859-60$ pp. TxU Dublin: re-printed by $A$. Rhames, and are to be sold by the booksellers. $1714.8^{\circ}$; (i-ii) iii-xvi 1-70 71-72 blk. pp. O, KU

This famous whig tract was written by Steele to remind anyone who might have forgotten them of the principal tenets of that ousted party and its particular devotion to the revolution of 1688, the Hanoverian settlement, the Act of Union, and the rights and liberties of the subject as embodied in those events and documents. Scotland obviously was not central to the argument; but since Scotland played an important role in the development of the theme, this work is included. It provoked an even more famous retort by Swift (No. 306) with one of the most controversial paragraphs in the entire Anglo-Scottish controversy of the reign of Queen Anne. Stcele's expulsion from the House of Commons was in part a response to this pamphlet.

94 The cry of the north: fair trade, fair seizure, fair tryal. ... Edinburgh, printed by James Watson, and sold at his shop, next door to the Red-Lyon, opposite to the Lucken-booths. [1707/1708]. $8^{\circ} ; 1-23-2324$ pp. E, CtY

Union inevitably brought disruption, and nowhere was this more obvious than in the economic sphere. After 1 May, the Scots were thrown into the arena with the English, who were more prosperous and more experienced. This writer, a Scot, lamented the attitude of some few from England, who saw the Scot as easy picking and who viewed the law and the new state as a route to their own particular advantage. The writer demanded equality before the law and in all other spheres of government and trade.

95 The crying down of the money considered. [Edinburgh? 1706/1707]. $1 / 2^{\circ}$; both sides. L, E, LU-G, MH

Since Scottish coins were different from those of England, the union-which still was uncertain when this paper was written-would mean a recoining and a standardization of measures with regard to coinage. This paper warned the Scots as to the change and predicted how it might affect them. The author thought that the results would be beneficial to the Scot with coins in hand, for the advantage would be on the side of Scottish coins.

96 The danger of Popery, from Scots and English colleges and seminaries abroad. [1714?]. $8^{\circ} ; 12-8 \mathrm{pp}$. DFo

This pamphlet was not aimed at Scotland as such, nor did it report on events in Scotland exclusively; but there is an interesting section in which the Highlanders, the Episcopalians, and the Catholics all were identified with Jacobitism. The linking of these elements already had been suggested and developed prior to this date, but it would take the ' 15 to make that connection a certain and fixed one in the minds of many in both England and Scotland.

- For a complete bibliography and discussion of this pamphlet, see Tracts and Pamphlets by Richard Steele, odited by Rac Blanchard, 1944, 1967. 
A defence of the magistrates of Edinburgh. SEE: No. 179.

A description of Scotland and its inhabitants. SEE: No. 349.

97 A dialogue between a brewer and a gager, concerning the malt tax. [1713/1714?]. $1 / 2^{\circ} ; 12 \mathrm{pp}$. E

The malt tax which the British Parliament imposed upon Scotland in the spring of 1713 increased the Scottish malt tax to the level of the old English levy; this was done before the conclusion of the war-as required by the Treaty of Union-and was to be used in part to repay debts from that war in violation of the agreement. The outcry from Scotland was loud and without much effect upon the act itself- but the tax in fact was not collected for many years, due to local resistance and to a reluctance to provoke the public in Scotland. This paper was part of that outraged resistance to the tax.

98 A dialogue between an Englishman and a Scotsman, about repealing the Sacramental-Test. [1709] (E ms. note, September). $4^{\circ} ; 12-8$ pp. E

While the Sacramental Test was held necessary to the securing of the Church of England, it was not viewed in the same light by the Scots, who regarded it as a hurdle to them (which it was) in their attempt to secure offices in England. The Scots wished it repealed as part of the more complete union so long discussed but, to them, so seldom secured.

\section{A dialogue between S. and E. [London? 1709/1710]. $12^{\circ}$; one side. E, LU-G MH}

The problems of salt, fishing, draw-backs, and Anglo-Scottish rivalry in the sale of fish all continued after the union. The Scots claimed that they did not receive what was due them under the union; the English claimed that they were penalized by the treaty. This answer sought to contrast the cases of England and Scotland and to assert that the Parliament would do what was right. This was written in answer to No. 63.

A dialogue betwixt a burgess of Edinburgh, and a gentleman lately arrived in Scotland, concerning the union and behaviour of the Presbyterian ministers in that great affair. [Edinburgh. 1713]. $8^{\circ}$; $1-1516$ pp. (GroRge LOCKHART.) L, E

The author did not disguise his conviction that Scotland was in rags because of the union. This pamphlet is an excellent example of Jacobite ideas on the consequences of the unionor rather, on the many grievances relative to the union which were common to various groups in Scotland. The purpose of the tract was to unite all of those separate complaints into one cause-the restoration of the Pretender. It is interesting as an indication of the complaints as of 1713 .

101 A dialogue betwixt a minister of the Church of Scotland, and two of the elders of his congregation, about the Abjuration-Oath. 1712. $8^{\circ} ; 1-2$ 3-112 pp. (James SMith.) L, E, CtY

This extremely long-winded discussion of the Oath of Abjuration and the many objections made to it by Presbyterian ministers and others in Scotland continued a series of pamphlets in defense of those who had accepted the oath. This particular work, cast in the form of 
a conversation between a minister and two worried elders, sought to answer each objection, and did so with considerable authority and vigor, if with but little depth. See also No. 375 . Cf.: Nos. 272, 224, 267.

102 A discourse between a Mureland man, and a stablers wife, concerning the burying in woolen. [Edinburgh. 1707]. $12^{\circ}$; one side. L

The occasion for this pamphlet was an economic reality evident soon after May, 1707. Wool could not be exported from Britain, but English cloth could be brought into Scotland and sold more cheaply than Scotch cloth. The Scots naturally were distressed. The pamphleteer admonished them to work hard and to prosper in the English fashion, but it is questionable if this advice soothed many of them.

103 A discourse concerning The union. [Edinburgh? 1706?]. $4^{\circ} ; 1-8$ pp. (anonymous, although sometimes erroneously attributed to Defoe).

L, E, O, LU-G, CtY, DFo, KU

[variant:] ... the union. $\quad \mathrm{E}$

This author ultimately proposed and supported a full and incorporating union as being in the best interest of Scotland, but his arguments were primarily of a negative nature. He did not believe that Scotland could exist independently of England, nor in alliance with other great states, without provoking England to an invasion, which he thought the English would win. Since a federal union would not resolve that English problem, he settled upon an incorporating union as being in England's best interest, and therefore more likely to be buttressed and protected by her. This was an answer to No. 192, and was in turn responded to by No. 135 .

104 A discourse of a cavalier gentleman, on the divine and humane laws; with respect to the succession. 1706. $4^{\circ} ; 1-3$ 4-12 pp. Don A. B. (Sometimes attributed to Sir Alexander Bruce, 4th Earl of Kincardine; sometimes to Captain Alexander Bruce.) L, E, LU-G, DFo, InU, MH (lacking pp. 9-12)

$$
4^{\circ} ; 1-34-8 \text { pp. } \quad \text { CtY }
$$

This Jacobite pamphlet advanced many of the usual arguments current among that faction in Scotland and in England. For man to meddle with God, the succession, or the divine laws which governed the state was to court disaster. James Stuart had been deprived of his throne; the inconvenience of his religion was insufficient cause, for James had not been given the opportunity to take the oath nor to show his willingness to abide by the laws of the land.

105 A discourse of present importance, humbly offered to the consideration of the Right Honourable Members of Parliament, under the following heads. I. Of government in general, and that of Scotland in particular. II. Of the constitution of Parliament, in all its parts. III. Of the Oath of Parliament. IV. Of publick and private interest; wherein several proposals are tender'd for encouraging the one, and disappointing the other. And, V. Whether the declaring of the succession at this present juncture, be the interest of Scotland, or not? [Edinburgh?]. 1704. $4^{\circ} ; 1-23-28$ pp. L, E, DFo, InU 
After an extensive review of the nature and purpose of the Scottish state, its Parliament, nobility, gentry, and tradesmen, and its present and past parties and divisions religious and political, the author concluded with an analysis of the state of Anglo-Scottish relations. The author viewed England with extreme scepticism and doubted its willingness to negotiate in good faith. Rather he saw the English as unscrupulous and untrustworthy pcople who had to be dealt with from a position of strength; Scotland's succession and her military preparedness were but parts of the general need to be ready to defend Scotland from England.

106 A discourse upon an union of the two kingdoms of England and Scotland. London: printed for A. Baldwin, near the Oxford-Arms in Warwick-Lane. 1707 (Moore, after the Scottish Parliament had passed the Act of Union, but before it was ratified in London; published ca. 28 January). $8^{\circ}$; $1.45-4748$ pp. (Daniel Defoe?)

$$
\text { E, O, LU-G, CtY, DFo, InU, MH }
$$

The arguments in this pamphlet were directed primarily at the average Englishman who feared a union with Scotland, but who was willing to listen to reason. The author stressed the advantages of a penceful northern kingdom no longer looking to France for assistance. The Protestant succession then would be secured, and France and Roman Catholicism, as well as the Pretender, would be reduced in potential power. Trade and Anglicanism would be advanced, not threatened; and Episcopacy in Scotland inight be assisted as well. It was a simply written panphlet directed toward a more or less popular audience.

107 A discourse upon the union of Scotland and England. Containing I. A brief account of the kind proposals made to the Scots by the English, in the reigns of Henry VIII. and Edward VI. 1I. A short history of treaties on that head since the union of the crowns, shewing that the English court have insisted on harder terms since that time [III-VI] . . Humbly submitted to the Parliament of Scotland, by a lover of his country. 1702 (dated 5 October; $H W L$, November). $8^{\circ}$; 1-3 4-6 1-134 pp. (George Ridpath.) L, E, O, InU

1702. $8^{\circ}$; (i-ii) iii-viii 1-143 122 147-179 $182-183$ 186-187 190-191 194 pp. E, CtY, DFo (correctly paged, 147-186), $\mathrm{MH}$

[idem] A discourse upon the union of Scotland and England, shewing among other things, the grivances of Scotland in relation to trade; and the advantage it shall receive by a freedom thereof, cannot compense the losses it will otherways suffer by the union; and how since the union of the crowns there has been a prevailing party in the court of England, who have been imposing upon Scotland both in relation to church and state, obliging the latter to comply with that which was worse in the constitution of the former, and barring them that which is better in their own, \&c. 1706. $8^{\circ}$; (i-iv) 12-134 pp. (This 1706 edition had a new preface added).

$\mathrm{E}$

The author of this tract was against the union, which he felt was not in Scotland's best interest. He argued that Scotland had not been offered good terms since the union of the kingdonis, and since then the English had lost few opportunities to impose upon the Scots. The present terms were not acceptable to the Scots either in the political or the re- 
ligious spheres. The recent history of Scotland demonstrated that anything left to the generosity or good faith of the English would be sought in vain once a union was concluded.

108 A discourse upon the uniting Scotland with England: containing the general advantage of such an union to both kingdoms. The several ways of uniting nations. The difference of religion, laws, and nobility, \&c. adjusted by the law of nature, and the practice of all nations in such cases. With divers original papers deliver'd by the commissioners of both nations to one another about an union in $1667 . .$. London, printed for James Knapton, at the Crown in St. Paul's Church-Yard. 1702 (HWL, November). $8^{\circ}$; (i-iv) 1-5 6 blk. 7-92 pp. (Blackerby Fairfax.) L, LU-G, DFo, InU, MH

The author of this work, which was published in the fall of 1702 when the commissioners for a union first were meeting, sought to anticipate all objections from the Scots and to present union as a positive advantage in every sphere. Fairfax wrote it as though he were a Scot, and the objections which he discussed werc viewed as though from a Scots viewpoint. It should be regarded as a long, discursive tract written to advance the union, probably paid for by the English.

109 The dissenters in England vindicated from some reflections in a late pamphlet, entituled, Lawful prejudices, \&c. [Edinburgh. 1707]. (Healey, before 27 January). $4^{\circ} ; 1-8 \mathrm{pp}$. (Daniel Defoe.) L (mislaid), E, LU-G, $\mathrm{CtY}, \mathrm{DF}$ o

There were Presbyterians in Scotland who were more than somewhat skeptical of the dedication of the Presbyterian dissenters in England to the fulfillment of the principles of the Solemn League and Covenant. Webster in particular doubted their commitment; this work sought to refute charges which Webster had made against the dissenters (No. 187). In particular Defoe pointed out that compromises had been made by the Presbyterians in Scotland in the past when disestablished, and advanced the idea that however much they might fall short, they still were closer to Scots Presbyterians than anyone else in England. Webster responded in No. 40, to which Defoe replied in No. 287.

The dissenters vindicated; or, a short view. SEE: No. 409.

110 A draught for a national church accommodation; whereby the subjects of England and Scotland, however different in their judgments concerning Episcopacy and Presbytery, may yet be united, in regard to the Queen's headship over both, in one church and kingdom of Great Britain. London; printed for A. Baldwin in Warwick Lane. 1705 (HWL, January). $4^{\circ}$; 1-2 3-11 $1213-3132$ pp. (John Humfrey.) L, O (lacking pp. 13-31)

[another edition]. London; printed for A. Baldwin in Warwick Lane. 1705. $4^{\circ}$; 1-2 3-31 32 pp. E, LU-G, CtY, DFo

[variant:] A draught for a national church accommodation; whereby the subjects of North and South-Britain, however different in their judgments concerning Episcopacy and Presbytery, may yet be united, in regard to the Queen's 
headship over both, in one church as well as kingdom of Great Britain. London, printed for A. Baldwin in Warwick-Lane. 1709. $8^{\circ}$; $1-2$ 3-11 12 13-31 $32 \mathrm{pp}$. L

[variant:] ... North and South-Britain, however different in their judgments concerning Episcopacy and Presbytery, may be united. Edinburgh, printed by James Watson; and sold at his shop, next door to the Red-Lyon; opposite to the Lucken-booths. 1709 (ca. $22 \mathrm{March}$ ). $4^{\circ}$; (i-ii) iii-viii 1-8 pp. E (lacking pp. 1-8), CtY

Neither Anglicans nor Presbyterians were satisfied with the religious terms of the union of 1707 , and each group hoped for an eventual unification into one (its own) church. Humfrey proposed a more tolerant (and thercforc unacceptable) solution. His national church, which used England as an example, encouraged a union in government, not worship, and concentrated upon the acceptance of the monarch as the ultimate governing authority over all churches. Civil and military offices would have been opened to almost all in return for an acceptance of that royal supervision. The plan required a far greater degree of religious toleration than wis evident in 1709 , and the plan failed.

111 Draught of an Act for Toleration with a few short remarks thereupon. [Edinburgh? 1703?]. $2^{\circ} ; 1-4 \mathrm{pp}$.

The Act for a Toleration of Episcopalians in Scotland found few supporters anong the members of the established church there, and this Scotsman was no exception. The toleration was objected to on historical, religious, legal, and polemical grounds. Every popular argument for it was objected to and held to be against the best interest of Scotland and the church of that kingdom as established by law.

112 The eight and ninth articles of the Treaty of Commerce, with relation to the trade of Scotland with France, considered, in a letter from a Member of Parliament, to a Member of the Royal Burrows, with a postscript in answer to a letter, directed to the author of the Mercator. Edinburgh, printed by John Moncur, and sold by William Brown at his shop foreagainst the entry to the Parliament-Closs. 1713 (before June-July). $2^{\circ} ; 12-4$ pp. E

[variant:] The eighth and ninth articles of the Treaty of Commerce, with relation to the trade of Scotland, with France, considered; with a postscript, shewing the falsities of a letter, publish'd in the Mercator. Printed at Edinburgh; and reprinted at London, for J. Baker, at the Black Boy in Pater-noster-Row. 1713 (ca. 13 August). $8^{\circ}$; (i-ii) 1-3 4-22 pp. L, LU-G, DFo, InU, MH, $\mathrm{KU}$ (L, LU-G, MH lacking half title page)

The proposed treaty of commerce with France aroused considerable controversy in the late spring of 1713, and this pamphlet was a part of that debate in the Parliament and in the press. Scotland was not a major consideration in the proposed bill, but this writer carefully noted in how few ways it would benefit Scotland. He concluded that Scotland had but few exports which would be saleable in France under the treaty, and suggested that efforts to view the bill as especially beneficial to Scotland were without foundation. 
who was executed with others of his crew, under the pretence of being a pirate, \&c. in Scotland, April the 11th 1705. London. printed and sold by the booksellers of London and Westminster. $1705.12^{\circ}$; one side. L, O

The execution in Scotland of Captain Green for piracy had the predictable results in England, where Scottish justice was viewed in an increasingly bad light. The English ship, the Worcester, had been forced into a Scottish port by bad weather and, while it was there, rumors circulated that its crew had engaged in acts of piracy against Scottish ships. The trial and execution of Green and his first mate were highly charged affairs, both in Scotland and in England. This elegy was written to exploit all of the emotional appeal which existed in England for Green. No heartstring was left untugged.

114 An elegye upon the never enough to be lamented decease of that antient illustrious and venerable Lady Princess Scocia. [Edinburgh. 1707]. $1 / 2^{\circ}$; one side.

$\mathrm{E}$

This poem in memory of Scotland introduced all of the old and new laments for past and present, as well as the lost potential for future glory. The future indeed would never look so bright as did the past to this poet.

115 England's, and North-Britain's, happiness, prov'd to be greater in $\mathrm{Her}$ Present Majesties reign, than in former ages, by Acts of Parliament, history, and authentick authors. London. $1709.4^{\circ} ; 1-23-32$ (1-16) 33-56 pp. L, LU-G, InU

This rather strange pamphlet drew together works written at different times by different people on a variety of subjects which are not obviously related. After a lengthy discussion of the historical interaction of England and Scotland, the author introluced a long section on the militia, reprinted materials on a toleration and its effect, and concluded with a discussion of the historical and immediate consequences of the union. He seemingly had no single purpose in this most eclectic tract.

116 An English ointment for the Scotch mange: or, a short memorandum of the Scots cruelty to Captain Thomas Green, \&c. London printed, and sold by B. Bragg, in Avemary-Lane. [1705] (written after Green was executed). $12^{\circ}$; both sides. L, O, InU

This author, along with many Englishmen, expressed intense displeasure at the execution of Captain Green, and was convinced not only that Green was innecent of piracy, but also that "justice"-as well as the mob-in Scotland had engineered or demanded his execution. He viewed the execution as a calculated insult to the Quecn, to England, and to Englishmen, and one which boded no good for those to the south. It was a particularly nasty paper, and one which did not scruple to throw all of the more disagrecable epithets at the Scots.

Enquiry. SEE: Inquiry.

117 'The equivalent explain'd. [Edinburgh? 1706]. $4^{\circ} ; 1-8$ pp. E, LU-G

For a large part of the pamphlet, the author simply and even objectively explained the 
equivalent to be paid to Scotland by England, and why it was paid. The purpose of the tract, however, became clearer when the Company of Scotland's moneys were examined: the author then proposed that the assets of the Company and the moncys due it from the cquivalent should be invested in a fishing industry which would make both Scotland and England wealthy.

118 An equivalent for De Foe. [Edinburgh. 1706]. $12^{\circ}$; one side. (JoHN Hamilton, Lord Belhaven, although occasionally attributed to Dugald Campbell.) L, E, O (copy mutilated)

This mocking personal attack upon Defoe was written by one who knew him and who also knew of his activities in Edinburgh. Defoe's four Essays (Nos. 119, 120, 121, and 138), as well as his poetical endeavors, were detected and condemned. The author's distaste for the union was as great as his scorn for Defoe, the hired writer for union. The sequence of the debate was: No. 241, which was answered by Nos. 398 and 88 as well as Nos. $30,525,355,332,374,118$.

119 An essay at removing national prejudices against a union with Scotland. To be continued during the treaty here. Part I. London [Printed for B. Bragg, at the Black-Raven in Pater-Noster-Row]. 1706 (HWL, April; Lee; Moore, 4 May). $4^{\circ}$; (i-ii) 1-30 pp. (Daniel. Defoe.) L, E, O, LU-G, $\mathrm{CtY}, \mathrm{DF}$, InU, $\mathrm{MH}$

Defoe here was seeking to remove both English and Scottish national prejudices against the union and therefore addressed himself to some of the more popular objections of a general nature. After discussing the history of the interaction of the two kingdoms, he gave credit where he could to both, and discounted other events as the product of bad advice. The Scots were cleared of the charge of killing or selling Charles I; their prosperity after the union would be to the advantage of all Britons; peace would be a common gain; safety and security would benefit Scot as well as Englishman. Religion, that most difficult of all prejudices, was held to be assisted by the union. Neither the Anglican nor the Presbyterian church was endangered. It was written as an optimistic and somewhat naive approach to prejudices as they would be displayed in the union debates to come. This first of the Essay series was followed by Nos. 120, 121, 138, 135, 499.

120 An essay at removing national prejudices against a union with Scotland. To be continued during the treaty here. Part II. London. 1706 (Lee; Moore, 28 May). $4^{\circ}$; 1-2 3-32 pp. (Daniel Defoe.) E, O, LU-G, CtY, DFo, InU, $\mathrm{MH}$

[variant:] Edinburgh reprint of No. 119 and No. 120 above. $2^{\circ} ; 12-50 \mathrm{pp}$. (Essay II begins on p. 28; Defoe denounced this as a piracy.) $4^{\circ} ; 12.5152$ blk. pp. (Essay II begins on p. 27). KU

In this second essay Defoe envisioned a new Britain which would become harmonious, tolerant, wealthy, and secure. England would have peace, safety, and assistance from Scotland, while Scotland would gain in trade, industry, and employment. Inequalities would be remedied and Scotland relieved from political tyranny and economic depression. This second essay, however, was more concerned with taxes than with other aspects of the 
union, and the subject was explored in depth. Scotland would be allowed to pay a smaller share, as befitted her lesser wealth. It was an optimistic tract filled with great hopes and little realism, written, Defoe later claimed, to calm English, not Scottish fears. The Essay series of which this is the second, also included Nos. 119, 121, 138, 135, and 499.

121 An essay at removing national prejudices, against a union with England. Part III. By the author of the two first. [Edinburgh]. 1706 (Moore, Healey, before 29 October). $4^{\circ}$; 1-2 3-35 36 blk. pp. (Daniel Defoe.) L, E, O, LU-G, CtY, DFo, InU, MH, KU

In his third essay Defoc claimed that he had been misunderstood in Scotland, where his works were thought valuable against the union. He protested that such was not the case; Scotland would gain in trade, religion, civil government, and liberty and sovereignty. She would have access to all of England's markets and supplies. Presbyterians would be protected forever from an assault from Episcopacy. Her representation in the new Parliament would protect her interests, and Scots would be securc in the liberties which Englishmen also crijoyed. It was a frank and open appeal to the Scots to support the union. This was an answer to No. 445 . It also was part of the Essay series: Nos. 119, 120, 121, 138, $135,499$.

122 An essay concerning inland and foreign, publick and private trade; together with some overtures, shewing how a company or national trade, may be constituted in Scotland, with the advantages which will result therefrom. ... [1704]. $4^{\circ} ; 1-8$ pp. (T. W. Philiopatris; i.e., William Patrerson.) E, LU-G, MH

Paterson's scheme for the improvement of Scotland's trade and commerce was closely tied to the creation of a Board of Trade and a company which would concentrate Scotland's energies and direct her merchants toward a single goal. The author was interested not only in promoting such a company, but also in educating Scotsmen to a more sophisticated method of trading than they were used to. This answered No. 502, as did No. 276.

123 An essay on the new project for a land-mint, proposing a proper and practicable scheme and expedient and how to put the same under due and regular management, in this conjuncture; not only for the speedy supplying the present scarcity of money; but also for the advancing of trade and other national improvements. By the author of The character of the true publick spirit. Edinburgh, printed by the heirs and successors of Andrew Anderson, printer to the Queen's most excellent Majesty. 1705. $8^{\circ}$; (i-xii) 1-31 32-36 pp. (ANDREw Brown.) E, LU-G, MH

The interest of Scotland in a reform of the financial structure, and in particular in the introduction of new banking and currency practices, was the motivation for this tract. This question of Scotland's economic plight would be one of the more important issues in the union debate. This was reprinted in No. 457. Cf. Nos, 376, 345.

124 An essay, shewing, that there is no probability of there being so much French interest, as it's certain there's English influence in our present Parlia- 
ment of Scotland. [Edinburgh?]. 1704. $4^{\circ}$; $1-2$ 3-8 pp. (William AlexANDER.) $\quad \mathrm{E}$

In 1704, the Scots did not hold the English in high esteem, and the author of this tract was no exception. He noted that while there was much talk in the press about a Frcnch interest in Scotland, there was more reality of an English interest in the Scottish Parliament. While neither of the two external states was particularly attractive, the author did concede that England might be a less dangerous master than France, but to him the choice was not a good one. Overall, this was an outraged protest by one who wished for the preservation of Scottish independence, but who was doubtful that it could be maintained.

125 Essay upon industry and trade, shewing the necessity of the one, the conveniency and usefulness of the other, and the advantages of both. . . Edinburgh, printed by James Watson in Craig's-Closs. $1706.4^{\circ}$; 1-2 3-40 pp. WiLLIAM BLACK; often attributed to "David Black," about whom nothing is known. This attribution apparently comes from Wodrow's hand-written note on $\mathrm{E}$ copy.) I, E, O, LU-G, CtY, MH

In the controversy over the nature and course of the Scottish economy, this author belonged to that group which sought to improve the exploitation of native products-wool and fish in particular-and to cncourage the export of finished products rather than raw materials. Neither England nor the union as such werc seen as solutions to Scotland's problems; rather, Scotland must expand the export of finished goods and curb the importation of needless luxury items.

126. An essay upon the design, the reference, the penalty and offence of the Abjuration Oath, in a letter to a Presbyterian minister. From whence it will appear, that such of the ministers of this church, as have refused the Abjuration, have not walked upon such insufficient grounds, as are represented in some late pamphlets. 1713. $4^{\circ} ; 1-34-3536$ pp. (EBenezer ERskine.) E, O

The more determined and uncompromising of the clergy of the Church of Scotland could not in conscience take the Oath of Abjuration, but they were abandoned and left exposed by their less scrupulous brethren who swore it with personal reservations. This tract sought to defend those who had refused it, and to show that those men were correct in their preseverance and concern for the church as established by law.

127 An essay upon the equivalent. In a letter to a friend. . . [Edinburgh?]. 1706 (after 23 July). $4^{\circ}$; 1-2 3-8 pp. E, LU-G, CtY, DFo, MH, $\mathrm{KU}$

The equivalent offered to Scotland was controversial, especially in the context of English and Scottish debts and incomes from all sources. These wcre not easily calculated; and few agreed as to the exact amounts involved in any figuring of taxes before and after the union in Scotland, and the relationship of those taxes to the equivalent. This tract disputed the figures used in these calculations, and contended that the equivalent offered to Scotland was inadequate to compensate for the increased duties imposed upon Scotland, and for the Ioss of the Scottish East India Company. 
128 An essay upon the XV. article of the Treaty of Union, wherein the difficulties that arise upon the equivalents, are fully cleared and explained. [Edinburgh]. 1706 (after July). 4º ; 1-2 3-28 pp. (Sir John Clerk.) E, LU-G, InU, MH

In Scotland the fifteenth article of the Treaty of Union between England and Scotland aroused great controversy, not only because it was economic in nature but also because it dealt with such emotional issues-the debts of the Company of Scotland, the equivalent, the customs and excise changes, and other matters of great importance to Scotland. This tract was an able attempt to present the various scctions of the article in as clear and favorable a light as possible, and to clarify some of the confusion which had grown around them. The author, Clerk of Penicuik, was not only for the union, but had been one of the men responsible for drafting the article.

129 An essay upon the union of the kingdoms of England and Scotland. [London] printed for John Nutt, near Stationers Hall. 1705 (Snyder/Clare, between 28 November and 12 December). $2^{\circ}$; $1-8 \mathrm{pp}$.

$\mathrm{CtY}$

[idem] A scheme for uniting the two kingdoms of England and Scotland, different from any that has been hitherto laid down. [Edinburgh? December $1705 / 1706$ ? ]. $4^{\circ}$; 1-12 pp. E, LU-G, CtY, MH

Having rejected either a federal or an incorporating union as generally defined, this author argued that the best union would be one in which each kingdom retained its own laws, religion, administration, and Parliament, but with a complicated system whereby the two scparate Parliaments-with additional members drawn from the other kingdom -would deal with matters of mutual importance in tradc, war and peace, and taxes. It was a system which sought to gain for Scotland access to English trade while gaining for England security, peace, excess population, and access to Scottish markets and products. Given the complexity of the proposed system, it could not be expected to receive much support, and it did not.

130 Essay upon the union. Shewing, that the subjects of both nations have been, by the union of the two crowns, justly intitled to all manner of privileges, which the ensuing treaty can give them. Therefore the work of the ensuing treaty is not so much to treat of new privileges, as to provide for the security of the old ones. And the best security against incroachments on both sides, is, to have separate Parliaments, with an express proviso, that no laws about trade, or the other common concerns of the united nations, shall be of force, unless agreed to by both Parliaments. London. 1706 (Ridpath, before 19 April; HWL, April). $4^{\circ}$; 1-2 3-31 32 pp. (James Hodges.) DFo, InU, MH, KU

. Edinburgh, re-printed by the heirs and successors of Andrew Anderson, printer to the Queen's most Excellent Majesty, and are to be sold at Mistriss Ogstoun's shop in the Parliament Closs. 1706 (ca. 6 May). $4^{\circ} ; 1-2$ 3-31 32 pp. L, E, O, LU-G

One issue which repeatedly surfaced in the union debate was that of the loss of the Parliament of Scotland and the incorporation of Scotland into a united Britain with one Parlia- 
ment. This author felt that an incorporating union would not be to Scotland's advantage, and this essay proposed a federated union in which Scotland's laws, liberties, religion, and trade might be protected. The author did not settle his points in as rational a fashion as one might have hoped, and the tract overall was weak. This pamphlet, along with Nos. 341,408 , and 419, was answered in Defoe's No. 138.

131 Eusebia Triumphans. The Hannover succession to the imperial crown of England, an heroick poem. ... London, printed for John Nutt, near Stationers-Hall. 1702 (MDCCII, III inked in). $2^{\circ}$; $1-56-789-5152$ blk. pp. [Title and text printed in Latin on verso of each leaf, opposite to English text.] Elkanah Settle. DFo

[variant:] ... Hanover. . . L London, printed for the author. $1705.2^{\circ} ; 1-13$ 14-575958 60 blk. pp. DFo

[idem:] Eusebia Triumphans. The Protestant succession as now establish'd, and inviolably secur'd, by the happy union of the imperial crowns of Great Britain. An heroick poem. ... London. Printed for the Author. 1709. $2^{\circ}$; 1-13 14-575959-7374 pp. LG, KU

By profession and inclination, Settle wrote commemorative verse for every occasion, and it was not unknown for him to adapt one set of verse to more than one occasion. In these lines of fairly standard laudatory poetry, there is praise for Anne, the union, and the Hanoverian succession.

132 A fair state of the question, betwixt the Presbyterian ministers in Scotland who have taken the Oath of Abjuration, and those who have refused it. In a letter from a Presbyterian minister in Scotland, to another at London. Edinburgh: printed by James Watson, and sold at his shop, next door to the Red-Lyon, opposite to thc Lucken-Booths. 1713. $12^{\circ} ; 1-23-12 \mathrm{pp.} \quad$ InU

The Oath of Abjuration gave many Presbyterians considerable difficulty, and some therefore attempted to limit or restrict their taking the oath and to impose caveats upon it. This author, who refused to take the oath, sought to show that those who had compromised were hypocrites, and were neither in law nor in the sight of God relicved of: the full responsibility of the oath as it was originally stated.

133 Faithful advice from England by an honest Scots-man. . . . Edinburgh. $1706.4^{\circ} ; 1-78-22$ pp. E, LU-G

Hodges wrote No. 341 against an incorporating union. The "editor" of this smaller work carefully removed from some 19 pages of that manuscript anything which might discourage union and then published it as this tract supporting a union. It was a clever use of a controversial pamphlet, and one certain to cause considerable confusion. In No. 456, to counter the ploy, the same section was reprinted as originally written.

134 The fifteen comforts of a Scotch-Man. London. 1707 (Moore, February). $8^{\circ}$; $12-8$ pp. "Written by Daniel D'Foe in Scotland" (Although attrib- 
uted to Defoe on the title page, all authorities have found the likelihood of his writing it doubtful). $\quad \mathrm{L}, \mathrm{O}$

A poem to the blessing of union as seen, supposedly, by a Scot, this doggerel seems to offer praise and to mark thosc advantages in foreign and domestic affairs which would come to Scotland as a result. Although the Defoc attribution is most doubtful, this piece apparently was written as a companion to his No. 494.

135

A fifth essay, at removing national prejudices: with a reply to some authors, who have printed their objections against an union with England. [Edinburgh?]. 1707 (Moore; E ms. note, 6 January; Healey, certainly before 17 January). $4^{\circ}$; (i-viii) $1-3536$ pp. (Daniel Defoe.) L, E, O, LU-G, $\mathrm{CtY}, \mathrm{DFo}, \mathrm{InU}, \mathrm{MH}$

The fifth essay essentially was an economic tract written by Defoe to clarify what he felt to be misunderstandings or misconceptions on the part of pamphleteers opposing the union. He investigated almost every facet of Scottish trade-real or imngined-and weighed all the new or old schemes for trade in and out of Scotland; he then sought to show that his own theories on Scotland's conmercial improvement werc more logical and reasonable than those advanced against the union. While the entire Black-Defoe debate was much broader, the direct line of controversy for this work started with Black's two works, Nos. 408 and 412. Defoc answered in No. 85. Black then responded in No. 191, to which No. 135 is an answer. Black answered this in No. 299; it also was one of the three tracts he treated in No. 331, the other two being Nos. 103 and 15. This also was part of Defoe's Essay series: Nos. 119, 120, 121, 138, 135, 499.

136 The following protestations sent down from London, giving the true account, as they were taken here, viz. The Duke of Hamiltouns protestation against the overture for establishing a certain way of settling the representatives of Scotland, to the Parliament of Great Britain, in the termes of the Treaty of Union. [at mid-page: Mr. William Cochran of Kilmaronock his protestation, to the same purpose] Edinburgh, printed by John Reid, at his house in BellsWynd. 1707. $1 / 2^{\circ}$; one side. L, E, O

The Parliament of Scotland was to select commoners and peers to the first Parliament of Great Britain in 1707, a decision which in part reflected an unwillingness to risk a general election after the uproar over the Union. Hamilton and William Cochran protested the procedure as a violation of the Treaty, but they were not successful.

137 The following two addresses were presented and read in Parliament, upon Saturday the 23 of November 1706. To His Grace Her Majesty's High Commissioner, and Estates of Parliament. The addressof (!) the Provest, Baillies, Town-Council, and other inhabitants of the burgh of Stirling. (on A2: To His Grace Her Majesty's High Commissioner, and the Right Honourable the Estates of Parliament, the address of the heritors, Magistrates, Town-Council, and other inhabitants within the town and paroch of Culross in Perth-Shire, and of the heritors and other inhabitants of the paroches of Saline, Carnock, and Torie in Fife-Shire. 1706 (23 November). $4^{\circ} ; 12-4$ pp. E 
The two protests which were printed together in this paper sought to prevent the union of England and Scotland, predominantly on rcligious, economic, and political grounds. The Church of Scotland was felt to be endangered; the best economic interest of Scotland was threatened; taxes and duties would increase; and the Parliament, laws, and liberties of Scotland would be lost. In content they did not differ substantially from many of the other pamphlets against the union.

A fourth essay at removing national prejudices; with some reply to Mr. H-dges and some other authors, who have printed their objections against an union with England. [Edinburgh?]. 1706 (Burch I, 4-14 November; E ms. note, 19 November). $4^{\circ} ; 1-23-4344$ pp. (Daniel Defoe.) L, E, O, LU-G, CtY, DFo, InU, MH, KU

In this work Defoe sought to refute arguments against the Union from several differcnt sources and on several different issues. Trade and industry as always figured prominently in his work, and herc he argued that Scotland would not suffer from a union but rather would benefit in all aspects. Politically he argued against a federal union and attempted to prove that an incorporating union would not work to Scotland's detriment. The loss of sovereignty, threats to Scottish law, the decaying future of Edinburgh, all were introduced and shown to be groundless fears. This answered Nos. 341, 408, 419, and 130. It, along with No. 85, was answered in No. 191, which was followed by Nos. 135 and 299. This also is part of Defoe's Essay series: Nos. 119, 120, 121, 138, 135, 499.

A friendly advice to the clergy of Scotland, in a letter from a wellwisher of the Church of Christ in Scotland by law establish'd to a minister of the Gospel at Edinburgh. Edinburgh: printed by James Watson, on the northside of the Cross in Craig's Closs; and sold at his shop, next door to the RedLyon opposite to the Lucken-booths. 1710 (between April and October). $2^{\circ}$; 1-4 pp.

$\mathrm{L}, \mathrm{O}$

Between April, when the second session of Anne's third Parliament ended, and September, 1710, when that Parliament was dissolved and new elections called, the government of Britain, in England and in Scotland, was in a state of change which resulted in the tory ministry of Harley and St. John. This pamphlet was concerned with the defense of the right of the Queen to dissolve the Parliament and to appoint such ministers as she might choose, and with the defense of the changes in the ministry.

A friendly return to a letter concerning Sir George Mackenzie's and Sir John Nisbet's Observation and responce on the matter of the union. . . . 1706 (letters 1 and 2 dated 22 August, 26 August). $4^{\circ}$; 1-2 3-29 30 blk. 1-7 8 blk.1-12 pp. (George Mackenzie, Earl of Cromarty.) E (lacking pp. 1-12), O, LU-G (lacking pp. 1-12), DFo, KU (lacking pp. 1-2, 1-8, and 1-12)

This tract was written to answer assertions made upon the authority of Sir John Nisbet and Sir George Mackenzie in denying to Parliament the right to conclude a treaty. This author sought to argue first the abstract principles involved in the alteration of a constitution, and then to apply those principles to Scotland. Cromarty concluded that not only had Kings and Parliaments altered the constitution, but that they had done so on numerous occasions. This was written in response to No. 192, and was answered by No. 410 . 
A full and exact account of the proccedings of the Court of Directors and Council-General of the Company of Scotland trading to Africa and the Indies, with relation to the Treaty of Union, now under the Parliament's consideration. In a letter to a person of quality. Containing the author's apology for publishing the same. ... [Edinburgh]. 1706 (dated 10 December). $4^{\circ}$; 1-2 3-40 pp. Roderick Mackenzie. L, E, LU-G, DFo, MH

In the making of the Treaty of Union, the affairs of the Company of Scotland could not be ignored. From a financial as well as an emotional viewpoint, they were intricately interwoven with Scottish reaction to union. In turn, Roderick Mackenzie was one of the few constant figures associated with the Company and with the case of Captain Green. His justification of his actions in the immediate more than in the distant past, and his proposals for the nearly defunct Company of Scotland, were primary topics in this long account of his involvement in Scotland and England in 1706, on his own behalf and on that of the Company of Scotland.

142 A full answer for Mr. George Barclay minister of the Gospel. To a scurrilous pamphlet published against him, in vindication of the Bishop of Edinburgh and the other administrators of the money collected; for the releif of the distressed Episcopal clergy in Scotland. Whereby his complaint, exhibited against them to the Lords of Session, is shewed reasonable; and the malice, folly, and falshood of the vindicator are made appear. ... Edinburgh printed by John Moncur at his printing house at the foot of the Bull-Closs. 1712. $4^{\circ}$; 1-2 3-28 pp. (Grorge Barclay.) L, E, O, KU

Barclay asserted that moneys collected for the relief of the Episcopal clergy of Scotland were being misused; this prompted Alexander Rose to answer him in No. 143. In vindication of himself, Barclay wrote this tract.

143 A full vindication of the right reverend the Lord Bishop of Edinburgh, and the other administrators of the charities there, from the calumnies, and the false and scandalous assertions and insinuations of Mr. George Barclay, in his defamatory libel, publish'd in the Flying Post, $\mathrm{N}^{\circ} .3181$. With an inhumane as well as unchristian design to hinder the charity of good Christians, towards the relief of the suffering Episcopal clergy in Scotland. London: printed and sold by G. Strahan, at the Golden Ball, over against the Royal Exchange in Cornhill. 1712 (ca. 10 May). $4^{\circ}$; 1-2 3-16 pp. (Alexander Rose.) E

[variant:] . . inhuman. ... Re-printed at Edinburgh, by James Watson, and sold at his shop next door to the Red-Lyon opposite to the Lucken-booths. 1712 (ca. 28 April). $4^{\circ}$; 1-2 3-16 pp. L, E

The plight of the Episcopalians ejected from positions in Scotland by the Presbyterians was not only grave but worsening by $1710-1711$. For their relief, the Episcopal bishops sought to raise noneys in England among the Anglicans. This action in turn angered the Presbytcrians and provoked a response from dissenters in England, who felt threatened by an activated Anglicanism. This paper sought to defend the way in which moneys were 
distributed in Scotland and to counter charges made by the Rev. George Barclay in the Flying Post that distribution was politically influenced. Barclay defended his position in No. 142.

144 General heads and questions touching the manufactories and fisheries of Scotland, submitted to the consideration of all such as have interest therein. [Edinburgh? 1710?]. $2^{\circ} ; 12-4$ pp. E, CtY

The fishing industry in Scotland attracted considerable interest throughout this reign. This tract was an attempt to analyze the deficiencies, the strengths, and the encouragements needcd to put the industry on a firm footing.

145 A general history of trade, and especially consider'd as it respects the British commerce: in which are particularly described, I. The history and reasons of the rise of commerce in England. 2. The decay of commerce in Scotland, and methods of recovering it. 3. The original of the Dutch fishery, and how they got it from the Scots. With other accounts of those matters both profitable and diverting. This for the month of August. London: printed for J. Baker at the Black-Boy in Pater-Noster-Row. 1713 (ca. 24 September). $8^{\circ}$; 1-2 3-44 54474648 pp. (Daniel Defoe.) CtY

Scotland played an especially important role in the third of this series of four works, in which the author traced the history of Scottish trade, its peak around 1500, and its decline since 1603. The union of the kingdoms in that year was thought to have been one factor in that decline, most visible in the fishing industry. The thrust here, however, was on the potential of Scotland now that the union had remedied the situation.

146 The generous and noble speech of William Wallace of Elderslie at the battle of Falkirk. [1707?]. 1/2 ${ }^{\circ}$; one side. L, E

The union offered ample opportunity and encouragement to those who wished to employ history and fable against the union. This half-sheet consisted of a paraphrase of Wallace's speech at Falkirk, commentary on the specch by Buchanan, and two short fables translated from Aesop, including the story of the eity mouse and the country mouse.

147 Good news from Scotland: or the Abjuration and the Kirk of Scotland reconcil'd. [Edinburgh?]. 1712 (E ms. note, 15 May). $8^{\circ}$; 1-2 3-14 15-16 blk.pp. (Archibald Prtcairn). E

[variant:] ... reconcil'd.... [London?]. 1712. $8^{\circ} ; 1-23-1415-16$ blk. pp. O

\section{InU}

Re-printed in the year 1712. $8^{\circ}$; $1-2$ 3-14 15-16 blk. pp.

CtY,

The Presbyterian clergy were in great distress over the Oath of Abjuration imposed upon them in 1712, and they protested, proclaimed, and howled most abjectly about violations of the Treaty of Union and of dangers to the church. This author, while obviously of no help to them, did introduce some much needed humor and wit, pointing out the many conficting oaths which the Presbyterians had taken, and broken, since the reformation. 
The entire pamphlet-which ranged freely over the state of religion and nature-was great tongue-in-cheek fun from a master of the art.

148 The great advantages to both kingdoms of Scotland and England by an union. By a friend to Britain. [Edinburgh?]. 1702. $8^{\circ} ; 1-23-32 \mathrm{pp}$. (HugH (hamberlen.) E

This tract favoring union between England and Scotland seems to have been published in Scotland and aimed at convincing the Scots that a union would not be a disaster for their kingdom. Because it appeared during the early stages of the discussion, it was little more than a general review of ancient and modern arguments for union, but it was to the point and straightforward.

149 Great-Britain's happiness: a pocm on the passing of the union, to which Her Majesty was most graciously pleas'd to give her royal assent on Thursday the 6th of March, 1706/7. [London? 1707] (Luttrell, 7 March). $1 / 2^{\circ}$; one side.

$\mathrm{MH}$

At the conclusion of the long process involved in passing the union treaty, the author of this poem hailed that happy day with a panegyric which began, "Sing, Sing, Ye Swains, in joyful Strains express. ..." The author is unknown.

150 Great Britain's joyful triumph, for the happy union on the first of May, 1707. London, printed and sold by John Morphew, near Stationer-Hall. 1707 (Luttrell, 5 May). $1 / 2^{\circ}$; one side. ICN

Those who rejoiced in the union tended to point to such external blessings as a united front against France and Roman Catholicism, and to such internal blessings as the uniting of all Protestants and the eventual conversion of all to one (Anglican) faith. Such was this poem, written to glorify Anne and the union.

151 Great Britain's union, and the security of the Hanover succession, consider'd. In a letter from Windsor of the 30th of December, 1704. to a Member of Parliament in London. By a person of quality.... London: printed, and sold by B. Bragg, at the Blue Ball in Ave-Mary Lane. 1705 (dated 30 December 1704; published ca. 5 January 1705). $4^{\circ} ; 3-45-22$ pp. (all copies lacking half title page). (Anonymous, although Coombs attributes to John Thompson Lord Haversham.) L, E, LU-G, DFo, InU

\begin{tabular}{ll}
$-1-23-20 \mathrm{pp}$. & E, LU-G, MH \\
\hline 1-2 3-12 pp. & $\mathrm{CtY}$
\end{tabular}

Scotland and the union were the primary themes of this tract, but attacks on the Dutch and a call for the successor to Anne to reside in England were equally controversial. The author urged the union in order to increase the number of men available for the navy and the merchant marine. He advocated the compensation of the Darien investors, and held out the successful conclusion to the problem of the successor as an inducement. This in turn led to a call to invite the successor to the throne to reside in England, a prospect 
not at all to the liking of Anne. Overall this was an extremely political pamphlet which used Scotland as a part of a complex English political scheme.

152 Greenshields out of prison and toleration settled in Scotland, or the case of Mr. Greenshiclds, farthcr examin'd. With some enquiry into the mistakes about that affair, which have so much impos'd upon the present age. London: printed for N. Cliff, at the Golden Candlestick in Cheapside near Mercers Chapel. 1710 (Moore, 24 April). $2^{\circ}$; 1-2 3-20 pp. (Daniel Deroe.) $\mathrm{MH}$

This tract was written essentially to balance or to counter charges made in England relative to the casc of Mr. Grecnshields, accused in Edinburgh and imprisoned for "illegal" religious activities thcre. The author asserted that the more common charges made against the Scots and against the Church of Scotland and the Scottish legal system were incorrect. In particular he opposed the idea that Greenshields had been imprisoned for reading the Common Prayer to an Episcopal clcrgy; that he had becn barbarously imprisoned; and that the Church of Scotland was the culprit. The author in all of these points attempted to vindicate the church, government, and people of Scotland relative to this case. This pamphlet was written in answer to No. 498, as was No. 325 .

153 The grounds of the present danger of the Church of Scotland. [Edinburgh. 1707] (signed January). $12^{\circ} ; 12$ pp. L, E, MH

In early 1707, the more militant and concerned members of the Church of Scotland were not satisfied that the Church was sufficiently protected. In particular, they objected to the presence of bishops in the British Parliament; to the denial of offices in England to Scots who had not taken the Sacramental Test; to the insecure position of the Scottish Privy Council; to the possibility of an act of toleration of Episcopacy in Scotland; and to the insecure statc of the laws respecting the church and the rights and liberties of individual Scots.

154 Hereditary succession in the Protestant line, unalterable. In answer to the Scots Bill of Security. London: printed for William Rogers, at the Sun against St. Dunstan's Church in Fleetstrect. 1704. $4^{\circ}$; (i-iv) 1-27 28, advt. pp. $\mathrm{O}, \mathrm{CtY}$

The Scots in 1704 were so angered by the English and so conscious of wrongs which they thought had been done to them that they passed the Act of Sccurity in part to spite the English. This author sought to show the Scots that the act was taulty in logic; that the wrongs-including cverything from the collapse of morals to the collapse of Darien-could not be solely the responsibility of the English; and that the issues involved were many and complex.

155 The High-Lander's answer to the L-d H-m's sp-ch. London, printed for John Green, near the Exchange. 1704. $4^{\circ} ; 1-4 \mathrm{pp}$. InU

$$
\text { . np. nd. } 4^{\circ} ; 12-4 \text { pp. L, CtY, DFo }
$$

[variant:] . . L. Haversham's speech. Re-printed in the year $1704.4^{\circ} ; 1-2$ 3-7 8 pp. E, $\mathrm{MH}, \mathrm{KU}$ 
The speech of 23 November which began this controversy was predominantly a criticism of English actions and policies, and only the last few paragraphs were directed toward Scotland. The rebuttals, of which this is one, likewise devoted little time to Scotland. Rather, Haversham was chastized for fomenting trouble and insulting the Scots. The activities of the Scots in and out of Parliament obviously made al defense of them difficult from an English point of view. Cf. Nos. 243, 322, 326.

156 Historia Anglo-Scotica: or an impartial history of all that happen'd between the kings and kingdoms of England and Scotland, from the beginning of the reign of William the Conqueror, to the reign of Queen Elizabeth. Comprehending their several homages, incursions, devastations, depredations, battles, sieges, leagues, truces, breaches, intermarriages, and divers other matters, worth knowing. Faithfully extracted from the best historians of both nations with a prefatory dedication. London: printed for John Hartley, next door to the King's Head Tavern in Holborn. 1703 (HWL, abstracted, February; 8 July, letters from Edinburgh reported that on 30 June the Scottish Parliament had ordered it burnt). $8^{\circ}$; (i-xvi) 1-240 225-240 225-423 424, advt. pp. JAMES Drake. L, E, O, DFo, InU, MH, KU

This "mock chronicle" was one of the most famous forgeries of the early eighteenth century. The author, Drake, was a high tory Englishman who wished to put the Scots in their place and who sought to do so by concocting an early seventeenth-century chronicle which purported to be an account of the history of Anglo-Scottish relations since the time of William the Conqueror. Needless to say, the chronicle presented matters from an English point of view, and did little to encourage Scottish assertions of independence for church and state. It aroused a tremendous response both in England and in Scotland, but in fact was more of a farce than a scrious effort by a would-be scholar. The sequence of the debate was: Nos. 362, 235, 482, 236, 156, 450, 35, 188, 160, 81, 451, 483, 238, 519, 422.

157 An historical account of the antient rights and power of the Parliament of Scotland. Humbly offer'd to the consideration of the Estates, when they come to settle limitations for the next successor. To which is prefix'd, a short introduction upon government in general. . . . [Edinburgh]. 1703 (ca. 6 May). $8^{\circ}$; (i-ii) iii-xxxii 1-160 pp. (GeORge Ridpath, although formerly attributed to Andrew Fletcher.) $\mathrm{L}, \mathrm{E}, \mathrm{O}, \mathrm{InU}, \mathrm{MH}, \mathrm{KU}$

This highly controversial pamphlet was written at a time when the Scottish Parliament was asserting its independence of the ministers in Scotland and in England. The issues before the Parliament were hotly disputed, and this work encouraged that body to assert itself and to act in the best interest of Scotland. The tract was extremely unpopular in official circles in Edinburgh and in London.

158 An historical account of the bittcr sufferings, and melancholly circumstances of the Episcopal Church in Scotland, under the barbarous usage and bloody persecution of the Presbyterian Church Government, with an essay on the nature and necessity of a toleration in the north of Britain. Edinburgh. 1707 (ca. December 1707/January 1708). 8; $1-23-40$ pp. Daniel Defoe).

L, E, O, CtY, MH 
[idem] Presbyterian persecution examined, with an essay on the nature and necessity of toleration in Scotland. Edinburgh. $1707.8^{\circ} ; 1-23-40$ pp. L, $\mathrm{E}, \mathrm{CtY}, \mathrm{DF}$ o

The Presbyterian Church in Scotland suffered from an English press which was hostile to it and which reported real or supposed activities in the name of the church with cvery exaggeration possible. This at least was the thrust of this tract which sought to counter some of the prejudices in England against the church and to show that the high church party in England had much to gain by so maligning the Presbyterians. It was a reasonable and well-argued tract, but one which would have had little impact.

159 An historical account of the union, betwixt the Egyptians and Israelites. [ca. 1710]. $8^{\circ} ; 12-8$ pp.

L

This recounting of the Biblical story of the Egyptians and the Israelites could not help but suggest the case of the Scots and the English, no matter how far-fetched the analogy. The Scots, who felt increasingly aggrieved, might have wished to see themselves as the Israelites, flceing from oppression, but the comparison was a weak one.

160 An historical essay, shewing that the crown and kingdom of Scotland, is imperial and independent. Wherein the gross mistakes of a late book, intituled, The superiority and direct dominion of the imperial crown and kingdom of England, over the crown and kingdom of Scotland, and of some other books to that purpose are exposed. With an appendix, containing the copies of some writs and seals, which illustrate this subject. Edinburgh. printed by the heirs and successors of Andrew Anderson Her Majesties printers. To be sold by the booksellers of Edinburgh. 1705 (ca. 22 June). $8^{\circ}$ (turned chain lines); (i-viii) 1-6899 70-280 281-376 pp. James Anderson. L, E, O, DFo, InU (copy with vertical chain lines)

Anderson took as his theme the belief that the crown and kingdom of Scotland had been, and were at the present, imperial and independent, and that claims to the contrary by England were founded upon forgeries and other fabricated or misunderstood materials. Atwood was his particular target, and he sought through an examination of records to prove that the assertions which Atwood made were without foundation. Anderson certainly was much more of a scholar than most who were involved in this controversy. The sequence of the debate was: Nos. $362,235,482,236,156,450,35,188,160,81,451,483$, $238,519,422$.

161 The history of the Mohocks from Quecn Elizabeth to this present time. [London] Printed, and sold by the booksellers of London and Westminster. [1712] (ca. 25 March). $4^{\circ}$; 1-4 pp. E

This high church diatribe is included here not for its attacks upon assorted whigs, dissenters, puritans, Williamites, and the like, but for its recounting of the Glencoe affair. The author asserted that Macdonald had been a loyal supporter of James $I$, and that the massacre had been arranged for the purpose of punishing him for that offense and for no other reason. 
162 The history of the union of Great Britain. Edinburgh, printed by the heirs and successors of Andrew Anderson, printer to the Queen's most Excellent Majesty. 1709. $2^{\circ}$; (i-xii) i-xxxii 1-60 1-116 1-76 1-273 274, errata 1-38 1-60 57-60 65-131 132 pp. (Since each copy located has a different collation and different pagination, this is given mercly as a sample). Daniel Defoe.

L, E, O, LU-G, CtY, DFo, InU, MH

[idem] A collection of original papers and material transactions, concerning the late great affair of the union between England and Scotland. Also an exact journal of the proceedings of the treaty as well at London as in Edinburgh. Wherein the privileges of the Presbyterian Kirk, and the case of toleration of Episcopal dissenters there, are very clearly stated. In five parts. Faithfully collected from the records and registers; by a person concern'd in the said treaty, and present in both kingdoms at the time of its transacting. London: printed for J. Knapton at the Crown in St. Paul's Church-Yard; N. Cliff, at the Bible and Three Crowns near Mercers Chapell; and J. Baker, at the Black-Boy in Pater-Noster-Row. 1712 (ca. 9 February). $2^{\circ}$; i-xxxii 1-60 1-116 1-76 1-273 1-38 1-131 132 pp. (as with the edition above, the pagination here is given as a sample. The dedications were omitted from this edition). E, CtY

Few works have enjoyed so controversial a reputation as Daniel Defoe's monumental History of the union; it was an amazing compilation of interpretative and primary materials-as scen by Defoe-relative not only to the union of $1706-1707$ but also to the history of previous attempts at union during the course of the seventeenth century. The Clark-Defoe debate (listed below) is but one example of the controversial nature of the work; but it was a masterpiece of contemporary writing and still must be consulted by all who wish to understand the nature of politics in the two kingdons. The controversy which devcloped around this work is as follows: Nos. 162, 283, 311, 28, 182, 336, 17.

163 The honour, happiness, and safety of union. Or, a sermon upon the uniting England and Scotland, preach'd at the parish church of St. James Clerkenwel, May 1. 1707. London: printed by W. Downing in St. John'sLane, and sold by Benj. Bragge, at the Raven in Pater-Noster-Row. 1707. $8^{\circ}$; 12-16 pp. Deurl Pead. L, E, O, DFo, InU

This prolific writer of sermons was not eager to attract undue attention but rather to stress the loyalty that was due to Anne, who in her infinite wisdom had supported the union. Religion was the key, he thought, to the difficulty; the Church of England was strong enough to withstand any problems which might come its way because of the union.

164 The honourable chiftains (!) of the Highland-clans vindicated, from the false aspersions, and scurrilous reflections, thrown upon them, by Ridpath the scandalous and justly condemn'd libeller. London, printed; re-printed at Edinburgh by James Watson, and sold at his shop, next door to the Red-Lyon, opposite to the Lucken-Booths. 1713 (dated 12 April). $4^{\circ}$; 1-2 3-8 pp. L, $\mathrm{O}$ 
Ridpath was one of the mote controversial writers of his day, and his The Flying Post often aroused his opponents to refute his attacks. In this case, Ridpath had questioned the loyalty, Protestantism, and independence of the Highland chiefs, who had signed an address to Anne. This author replicd in defense of them, asserting that Ridpath was incorrect and malicious, but the reputation of the Highlanders as Jacobites and Catholics made this rebuttal difficult to effect.

165 The horrid murther committed by Captain Green and his crue, on Captain Drummond and his whole men, under design of friendship by cutting off their heads, and tying them back to back, and throwing them into the sea, and sold their ship unto the Indians. [Edinburgh? 1705]. $1 / 2^{\circ}$; one side. L

This piece of doggerel made no attempt to disguise its hatred of Ciptain Green of the Worcester, who was accused, tried, and executed in Scotland for the murder of Captain Drummond and his crew and for piracy. It was a blatant attempt to arouse an emotional response in Scotland against Green, who was thought to represent England and English hostility toward Scotland.

166 The humble address of the Episcopal clergy. of the Diocese of Aberdeen, presented by Dr. James and Dr. George Gordons, attended by Mr. Dongworth, Mr. Gray and Mr. Greenshields, managers of the charitable contributions for dispersing Common Prayer Books, among the poor pcople in Scotland, and introduced by the Right Honourable the Earl of Marr, one of Her Majesty's Principal Secretaries of State. [Bib. Linds., Aberdeen? 1713] (in or soon after March). $1 / 2^{\circ}$; one side. (Anonymous, although sometimes attributed to Defoe.) $\mathrm{E}$

The Episcopal clergy of Scotland published this address of thanks to the Queen for the conclusion of the war, but also took the opportunity to thank Anne for her support of their efforts to obtain a toleration in Scotland, in particular the use of the English service. In conclusion they lamented their past, present, and future condition as a disestablished church in Scotland, and sought her continued assistance to them.

167 The humble address of the Scots merchants at London, to the Right Honourable the Lords Spiritual and Temporal assembled in Parliament, against passing the bill, for laying duties upon goods which may be brought by Her Majesty's subjects, from Scotland to England after the commencement of: the union. [1707] (April?). $1 / 2^{\circ}$; one side.

$\mathrm{E}$

The attempt by English merchants to prevent goods imported into Scotland before 1 May from being sold at an advantage after 1 May 1707 was one of the more dificult problems facing the English Parliament early that year. This address pointed out that such a bill was unreasonable, punitive, and in violation of the Act of Union.

168 An humble representation from the tanners, skinners, and dressers of leather in North-Britain, concerning the intended duties upon tann'd hydes, and dress'd leather, that may be tann'd and dress'd in North Britain. [London? 1711]. $1 / 2^{\circ} ; 1-2$ pp. L, MH 
One of the problems evident soon after the union was the difficulty in reaching an equal and just tax structure. In this case, the Scots protested that their hides were neither so fine nor so large as the leather in England, and, therefore, that the tax would weigh too heavily upon them if applied as in England. The problems of an underdeveloped area attempting to compete with a well-developed one were increasingly evident in petitions of this sort.

169 Information for Captain Thomas Green Commander of the Worcester, Captain John Madder his chief mate, and others, against Mr. Alexander Higgins Advocat, Procurator-Fiscal of the High Court of Admiralty. [1705]. $2^{\circ} ; 1-910$ blk. pp. E

This tract was primarily concerned with the preliminary stages of the trial of Captain Green and his crew in Edinburgh for assorted crimes, including piracy. Green and his men were accused of acts of piracy against Scottish ships and Green and his first mate werc tried in Scotland and execured. The matcrials reprinted here refer to the first presentation of charges against Green and his men, and the first evidence to be produced against or for him.

170 Information for Mr. Alexander Higgins Procurator-Fiscal of the High Court of Admiralty, against Captain Thomas Green Commander of the Worcester and his crew and complices. [1705]. $2^{\circ}$; 1-11 12 blk. pp. E

This pamphlet attempted to summarize the early stages of the trial of Captain Green and his men, and to present the evidence brought against them by the Procurator-Fiscal. Captain Green of the Worcester, along with members of his crew, had been accused of acts of piracy, tried in Scotland, and executed for those crimes. The majority of the material consisted of charges made by the prosecution and evidence supporting them, as well as a portion of Green's defense.

171 The innocency of Capt. Green, and his crew, vindicated, from the murther of Capt. Drummond. Published by order of the owners of the ship Worcester. London: printed by S. Bridge, and sold by J. Nutt, near Stationer'sHall. $1705.1 / 2{ }^{\circ}$; one side.

Captain Green and his crew were accused of piracy in general, and one of his crew asserted that Green also had had a hand in the taking of a Scots East India Company ship called the Speedy Return, commanded by a Captain Drummond. Testimony to the contrary was presented in this single sheet, which cleared Green of any involvement in the fate of that ship, although it obviously came too late to save him. Nor indecd could it clear him of the general charge of piracy.

172 An enquiry into the Caledonian project, with a defence of England's procedure (in point of equity) in relation thereunto. In a friendly letter from London, to a member of the Scots African and Indian Company in Edinburgh, to guard against passion. ... London, printed for John Nutt, near StationersHall; and sold by the booksellers of London and Westminster. 1701 (HWL, February). $4^{\circ}$; (i-ii) 1-2 3-52 6192 pp. (Walter Harris.) CtY, MH

In this lengthy attack, Harris reviewed the recent history of the Company of Scotland 
from an English point of view, and brutally, sarcastically, and nastily refuted each and every argument used by the Scots and the Company to explain failure in any terms other than their own incompetence.

173 An enquiry into the disposal of the equivalent. [Edinburgh. 1706] (Moore, after 20 December). $4^{\circ}$; $1-8$ pp. (Daniel Defoe.) E, LU-G, $\mathrm{CtY}, \mathrm{DFo}, \mathrm{InU}, \mathrm{MH}$

The controversy over the application of the equivalent in Scotland produced this rebuttal to a tract (No. 229) which argued that the cquivalent should first be used to repay losses suffered by those in Scotland who would be forced to recoin Scottish money to the English standard. Defoe argued that the first author did not understand either the moneys involved or the process by which recoinage was to take place. Neither foreign nor English moneys in circulation in Scotland would be recoined, only genuine Scottish coins.

174 An inquiry into the reasonableness and consequences of an union with Scotland. Containing a brief deduction of what hath been done, designed, or proposed, in the matter of the union, during the last age. A scheme of union, as accommodated to the present circumstances, of the two nations. Also states, of the respective revenues, debts, weights, measures, taxes and impositions, and of other facts of moment. With observations thereupon. As communicated to Laurence Philips, Esq; near York. London: printed and sold by Ben. Bragg, at the Black-Raven in Pater-Noster-Row. 1706 (dated 9 April; HWL, April, abstracted May). $8^{\circ}$; (i-xvi) 1-156 157-160 pp. (William Paterson.) L, E, O, LU-G, DFo, InU, MH, KU

This extended treatise on the union was written before the meeting of the commissioners to treat of a union, and it therefore took the form of a lengthy conversation, extending over many months, among several friends, on the union and its possible terms. The conversations rambled over almost every possible topic relative to the two countries-from the representation in the new Parliament to the tax on malt. The objective was to prepare the public in Scotland and in England for a union and to clarify points which already were causing confusion. It was a ponderous but at times perceptive work. It was answered in No. 341, which in turn was answered by Nos. 225 and 138 .

175 The insecurity of a printed overture for an act for the church's security. [1706] (E ms. note, 12 November). $4^{\circ}$; 1-8 pp. (RoBert Wyllre.) E

In the fall of 1706 , as the Parliament of Scotland worked through the Articles of Union, the difficult problem of the security of the Church of Scotland had to be dealt with in a way satisfactory to the church-and to Presbyterians who grew increasingly convinced that the church was in danger from union, and that it had been sacrificed to it. The Commission of the General Assembly formulated a petition which stated their initial objectives; but complications in the Parliament, in the Commission, and within the church and state prevented agreement. This paper argued that the printed bill for an Act of Security was inadequate to protect the church, but the act passed and became a part of the treaty as the civil charter of the Church of Scotland. 
Lauder, to their Commissioner in Parliament, in relation to the union proposed betwixt the kingdoms of Scotland and England. [1706] (after 23 October). $1 / 2^{\circ}$; one side. MH

This is yet another of the petitions and instructions prompted by the debate over union that was upcoming in the Parliament of Scotland. Like all the others, it opposed the union.

177 Israel and Judah made one kingdom: a sermon preach'd May the first, 1707. Being the day appointed for publick thanksgiving upon the union of England and Scotland, commencing on that day. ... London, printed for T. Parkhurst, at the Bible and Three Crowns Cheapside: J. Robinson, at the Golden-Lyon in St. Paul's Church-Yard; and J. Lawrence, at the Angel in the Poultrey. 1707. $8^{\circ}$; 1-2 3-16 pp. Joshua Oldfield. L, E, O, InU

This rather "thin" sermon attempted to avoid anything of a controversial nature, and to stress the positive aspects of the union. Such unity would mean security externally and internally, and would promote harmony and peace. It was a mild and innocuous sermon, determined to avoid any criticism of the Anglicans.

178 It is resolved, that the Parliament shall consider an act offered; whereby it shall be declared, that Scotland shall not be concerned in any war 'twixt England and any neighbouring potentate, without consent of the Scots Parliament, tho the King of England be King of Scotland. It is already voted, that none who shall be King of England shall be King of Scotland, unless the King and Kingdom of England secure the nation of Scotland in a free trade \& navigation in all their kingdoms and dominions; whereby with as much security as a Scots law can establish, if we have not the foresaid free trade and navigation, the King of England cannot be our King: and therefore, prop. The Act for Peace and War is altogether uscless. [Edinburgh? 1703?] (JulyAugust?). $1 / 2^{\circ}$; both sides. $\mathrm{E}$

Early in Anne's reign, Scotland realized that her freedon of action was extremely limited, and that any methods of pressuring England werc both few and often self-defeating. Scotland was neither strong enough to stand alone, nor weak enough to justify absorption. There did not even appear to be any promising way in which England might be persuaded to act favorably toward Scotland. This short work simply emphasized the difficulties inherent in any course of action which Scotland might undertake.

179 James Greenshields, Clerk, Appellant. The Magistrates of Edinburgh, Respondts. The Respondents Case. [1710] (May?, before the Lords' decision). $2^{\circ} ; 1-34$ pp. L

[idem] A defence of the Magistratcs of Edinburgh, and Lords of the Session, against the appeal and complaint of Mr. James Greensheilds, Clerk. James Greensheilds, Clerk, Appellant. The Magistrates of Edinburgh, Respondents. The Respondents case. [Edinburgh? 1710] (May?). $12^{\circ} ; 12$ pp. RPBJCB 
Greenshields had been arrested for conducting services in Edinburgh according to the Episcopal rites; his appeal of his conviction to the House of Iords naturally angered the magistrates of the city of Edinburgh, who denied his right of appeal to the highest of civil courts. They asked the House of Lords to dismiss his appeal, and to uphold their order forbidding him to exercise his ministry. At stake was the entire interaction of the Presbyterian church courts with the lower civil courts within Scotland. An adverse decision on this case would bring into question the degree to which the magistrates' courts could interfere at the request of the church. The appellant's casc was presented in No. 180.

180 James Greenshields, Clerk, Appel'. The Lord Provost, and Magistrates of Edinburgh, Resp. The Appellant's Case. [1710]. $12^{\circ}$; one side.

As indicated by the title, this single sheet sought to state briefly the particulars of the case of the Rev. Mr. Greenshields and his attempt to conduct services in Edinburgh according to the Episcopal religion and the English Prayer Book. In essence he denied the jurisdiction of the ecclesiastical courts over him and he disputed the legality of the sentence imposed upon him by the magistrates of Edinburgh. The respondents' case was presented in No. 179.

181 John Bull still in his senses: being the third part of Law is a bottomless-pit. Printed from a manuscript found in the cabinet of the famous Sir Humphry Polesworth: and publish'd, (as well as the two former parts) by the author of the New Atalantis. London: printed for John Morphew, near Stationer's-Hall. 1712 (ca. 16-17 April). $8^{\circ} ; 1-45-47$ 48, advt. pp. (JoHN Arbuthnor:)* $\quad \mathrm{L}, \mathrm{E}, \mathrm{O}, \mathrm{DFo}, \mathrm{InU}, \mathrm{MH}$

[title page reset]. InU

- London: printed for John Morphew, near Stationer's-Hall. 1712. $8^{\circ} ; 1-32$ pp. $\quad$ MH

The second edition. London: printed for John Morphew, near Stationer's-Hall. 1712 (ca. 24 April). $8^{\circ} ; 1-45-47$ 48, advt. pp. CtY, MH . The third edition. London: printed for John Morphew, near Stationer's-Hall. 1712. $8^{\circ} ; 1.45-4748$, advt. pp. O, CtY, MH . The fourth edition. London: printed for John Morphew, near Stationer's-Hall. 1712. $8^{\circ} ; 1-45-4748$, advt. pp. $\mathrm{MH}$ . Edinburgh: re-printed by James Watson, and sold at his shop next door to the Red-Lyon, opposite to the Lucken-booths. 1712 (before 25 April). $8^{\circ}$; 1-2 3-48 pp. (contents pp. 47-48, rather than 3-4; no advts.). L, E, MH

This delightful account of Peg (the Church of Scotland) and her stronger brother, John (the Church of England), was one of the few well-executed picces of propaganda produced by the first rank of writers in Jondon. Arbuthnot, Swift, Addison, and Steele, to name a few, rarely devoted much attention to Scotland. This piece by Arbuthnot, thercfore, is unusual in its merit, and in its compassion for and understanding of Scotland.

* For a more complete bibliographical discussion of this work, see John Arbuthnot, The History of lohn Bull, edited by Alan W. Bower and Robert A. Erickson, 1976. 
His interest in Scotland was secondary to other concerns, but it was a welcome work nonctheless. This is the third of the four parts of Arbuthnot's History of lohn Bull. The key to this part, and to the two preceding it, was provicled in No. 83.

182 A just reprimand to Danicl de Foe. In a letter to a gentleman in South Britain. Edinburgh. Printed by John Reid, Junior, and are to be sold at Alexander Henderson his shop in the Luckenbooths, and James Wardlaw his shop on the south-side of the street, below the Cross of Edinburgh, and also, at James Stewart his shop in the Salt Mercat in Glasgow. [1709/10] (before 1 April 1710). $4^{\circ}$; $12-8$ pp. (James Clark.) L, E, CtY, MH

The Rcv. Mr. Clark of the Tron Church, Glasgow, was accused in Defoe's History of the union (No. 162) of some indiscreet words in a sermon which were thought by many to have incited his congregation to violent action against the union. In this counter-attack, Clark told of his complicated negotiations with Defoe to suppress that account or to modify it, and of Defoe's unsatisfactory (in Clark's view) reply and evasions. Clark denied that he had said what Defoe accused him of saying, and he accused Defoe of duplicity, invention, and dishonesty. The controversy was: Nos. 162, 283, 311, 28, 182, 336, 17.

183 A key to the memoirs of the affairs of Scotland. London: printed for J. Moor, in Cornhil; and sold by the booksellers of London and Westminster. 1714. $8^{\circ}$; 1-2 3-19 20 blk. 21-23 24 pp. (GHorge Lockhart.) L, E, O (has two issues of this edition), $\mathrm{CtY}, \mathrm{MH}, \mathrm{KU}$

- The second edition corrected. London: printed for J. Moor, in Cornhil; and sold by the booksellers of London and Westminster. 1714. $8^{\circ}$; 1-2 3-23 24 pp. $\mathrm{L}$

. London: printed for J. Moor, in Cornhill; and sold by the booksellers of London and Westminster. 1714. $8^{\circ} ; 1-23-1920$ blk. Pp. L, O (has three issues of this edition)

The Key is just that; each reference in the Memoirs (No. 248) is identified by name as it appears in the text of the work.

184 The lamentations of Jeremiah, paraphras'd. Edinburgh, printed by John Moncur, and are to be sold by John Vallange book-seller. 1708 (before 24 November). $4^{\circ}$; 1-2 3-24 pp. (William Brown.) L, E

This rather thinly disguised lamentation for the lost sovereignty of Scotland utilized appropriatc Biblical verse to castigate Scotland for her sins which had led to this sorry state of affairs. Overall, it was rather well done.

185 The last speech and dying words of Captain Thomas Green, commander of the ship Worcester, and of Captain John Madder, chief mate of the said ship. Published by their own desires, from the copy which was read on the scaffold. [London] Sold by Benjamin Bragg in Avy-Mary-Lane. [1705] (April). $12^{\circ}$; both sides. $\quad$ L, InU, $\mathrm{MH}$ 
[variant:] The last spceches and dying words of Captain Thomas Green, commander of the ship Worcester, and of Capt. John Madder, chief mate of the said ship, who were executed near Leith, April 11th 1705. As contained in papers deliver'd by themselves upon the scaffold before their execution, and subscrib'd with their own hands at Edinburgh the 11th of April 1705. Came to the owners hands the 18th instant. Edinburgh, printed by John Read, 1705. Re-printed at London by S. Bridge (by order of the owners). Sold by John Nutt near Stationcrs-Hall. .. 1705. $12^{\circ}$; one side. L, E

[variant:] The last speeches and dying words of Capt. Thomas Green, commander of the ship Worcester, and of Captain John Madder, chicf mate of the said ship. The last speech of Capt. Thomas Green, who was executed near Leith, April 11. 1705. Published at their own desire from the copy which was read on the scaffold. [on verso:] The last speech of Captain John Madder, chief mate of the Worcester. [and] London, April 20. The following letter having relation to the above story; al we think needful to say of it, is, that we are told it comes from a plain seaman; and that we printed it from the original. (signed Geo. Kitching). [1705] (ca. 19 April). $12^{\circ}$; both sides. L

The controversy surrounding the trial and execution of Captain Green and his first mate for piracy against a Scottish ship was so intensc that no precise identification of the exact speeches which they wished left behind can be madc. England and Scotland both were so emotionally involved in this case that fake speeches were published days before the actual execution. This publication strongly upheld Green, who claimed that he was innocent of all crimes and, indecd, a God-fearing Englishman. This was answered in No. 414.

186 The last speech of Captain Green, publish'd by his own desire, from the copy which was read on the scaffold. [1705]. $1 / 2{ }^{\circ}$; both sides. E

The trial and execution of Captain Green for an act of piracy provoked many pamphletecrs in England and in Scotland to action; this was supposed to be the last specch of Green and was his final declaration of his innocence of the crime for which be was being cxecuted. To judge from this specch alone, one must conclude that Green indeed was a most wronged man.

187 Lawful prejudices against an incorporating union with England; or, some modest considerations on the sinfulness of the union, and the danger flowing from it to the Church of Scotland. . . E Edinburgh. 1707 (Healey, before 17 January; Lee, during the week of 16 January). $4^{\circ}$; $1-23-1516 \mathrm{pp}$. (James Webster.) L, E, LU-G, DFo, MH

Webster was against the union for many reasons, all religious. Hc felt that it violated the Solemn League and Covenant; that it would exclude Presbyterian ministers of state from the government; that it would allow a harmful religious toleration in Scotland; and that it would allow the continuation of the hated Sacramental Test after the union. This tract sparked off several replies, including Nos, 499 and 409), both by Defoe. He also answered No. 109, to which Webster replied with No. 40, with a further statement from Defoe in No. 286. Another pamphlet, No. 534, purported to answer this tract as well as No. 40, but 
in fact it took passages from Defoe's No. 409 out of contcxt and turned them against him. William Adams also replied to Webster in No. 222, to which Webster responded in No. 373; Adams answered with No. 377.

188 Leges Marchiarum, or border-laws: containing several original articles and treaties, made and agreed upon by the commissioners of the respective Kings of England and Scotland, for the better preservation of peace and commerce upon the marches of both kingdoms: from the reign of Henry III. to the union of the two crowns, in $\mathrm{K}$. James I. With a preface, and an appendix of charters and records, relating to the said treaties. London: printed for Tim. Goodwin, at the Queen's-Head against St. Dunstan's-Church in Fleetstreet. 1705 (ca. 8 March; HWL, abstracted, March). $8^{\circ}$; (i-viii) i-lvi 1-388 389-392 pp. (William Nicolson.) E, O, LU-G, DFo, MH, KU (lacking pp. ix-x)

In the preface to this work, the author engaged in an extended vindication of his ideas on the early history of the religious and political relations of England and Scotland, and attempted to deal with Atwond's often garbled ideas on that history. Indecd, by 1705 the tangled history of Anglo-Scottish relations and the precise rclationship of those two kingdoms in matters political and religious was too complicated to be easily disentangled. The sequence of this debate was: Nos. $362,235,482,236,156,450,35,188,160,81,451$, $483,238,519,422$.

189 A letter concerning the affair of Mr. Greenshields. [London? 1711] (dated 27 February 1710/11; published before 10 March). $8^{\circ} ; 1-32$ pp.

L, E

$$
\text { 1711. } 4^{\circ} ; 1-23-20 \text { pp. L }
$$

The arrest and conviction of Mr. Greenshields in Edinburgh for conducting the Episcopal service there was the occasion for this work, which was an attempt to defend Greenshields and the Episcopal clergy of Scotland, and to present the facts in his case to the English public. Although he presented a semblance of objectivity in the early pages, the author clearly favored Greenshiclds. The Scots Presbyterians appeared as intolerant religious fanatics, unwilling to allow the English service to be used in Edinburgh, and capable of imprisoning a minister of the Gospel for attempting to do so. Greenshields clearly emerged as a martyr to his religion.

190 A letter concerning the consequence of an incorporating uniou (!), in relation to trade. .. [Edinburgh. L ms. note, James Watson]. 1706 (E ms. note, 12 December). $4^{\circ}$; 1-2 3-27 28 blk. pp. L, E, O, LU-G, CtY, DFo, InU, $\mathrm{MH}$

Matters of trade were of primary concern in the pamphlet war in 1706 , yet few agreed on the relative weight of trade's specific aspects. This writer nominated the fish industry as of paramount importance, and argued that it would be best developed through an alliance with the Dutch. Proponents of union with England held out African, Asian, and American trade to tempt the excluded Scot; but the writer felt they represented only an illusion of profit and advantage, nothing at all as compared with the promise of a Dutch alliance 
to promote the fishing industry. Union, therefore, he felt should be avoided, for it would only prove detrimental to Scotland.

191 A letter concerning the remarks upon the considerations of trade, by the author of the 4th essay, at removing national prejudices. [1706]. $4^{\circ} ; 1-4$ pp. (William Black.) L, E, LU-G

Economic matters figured prominently in the union debate, and in this tract the issues involved were so confused that only the force of the argurnent remained. The points in difference were relative to the impact of the union upon the trade and industry of Scotland, in particular relative to the salt, malt, woolen, and fishing industries. Black restated his figures and conclusions and refuted those of Defoe and the assertions which he had made. While the entire Black-Defoe exchange is much more complicated, the direct line of controversy for this pamphlet is as follows: No. 408, answered by Nos. 85 and 138; both answered by Nos. 191, 135, and 299.

A letter concerning the union, with relation to trade. SEE: No. 193.

192 A letter concerning the union, with Sir George Mackenzie's observations and Sir John Nisbet's opinion upon the same subject. 1706 (E ms. note, July). $8^{\circ} ; 1-23-2324$ blk. pp. (Robert Wyllie.) E, LU-G, DFo, InU, $\mathrm{MH}$

This anti-union tract supposedly was written before the articles were released. The author strongly denied that Scotland would or could gain a fair deal from any Parliament controlled by the English, and doubted whether the articles--however defined-could effectively protect the church. He concluded by denying the Parliament's right to alter the fundamental constitution without reference to the populace. It was this last contention which aroused a response. The tract was answered by No. 103, which was in turn answered by No. 135; and No. 140, which was answered by No. 410 .

193 A letter concerning trade, from several Scots gentlemen that are merchants in England, to their country-men that are merchants in Scotland. [Edinburgh]. 1706 (Moore, 24 December). 4º ; $12-1516$ blk. pp. (Daniel Defoe.) L, E, LU-G, CtY, DFo, MH

[idem] A letter concerning the union, with relation to trade, from several Scots gentlemen, merchants in England, to their country-men, merchants in Scotland. London, printed for B. Bragg, at the Black-Raven in Pater-nosterrow. 1707 (Moore, 10 January). $8^{\circ}$; 1-2 3-16 pp. L, E, LU.G, CtY, DFo

Economic differences between England and Scotland made any treaty between the two difficult; to complicate matters, there were those in Scotland who were ready to confuse the issue further to discourage union. This tract sought to counter claims made in Scotland relative to the potential impact of union upon salt and salt taxes, beef and pork export, bounty money on oats and peas, the export of wool and linen, the excise upon malt, the import into Scotland of Irish woolens, and Scottish control over its own dutics. Since no one agreed on the figures involved or on the future of Scottish industry and trade, these confused (and confusing) tracts could do little to clarify the doubts of a sincere observer 
of the union debate. This, along with Nos. 138 and 85, answercd Black's No. 408; it also responded to his No. 412 . Black made a rejoinder in No. 26.

194 A letter from a brewer in the city, to a justice of peace in the country, concerning the malt tax. [Edinburgh? 1713] (dated 29 June). $2^{\circ} ; 1-34$ blk. pp. E, LU-G

By the Act of: Union, Scottish malt was exempt from the high English tax on it until the conclusion of the war. The government's decision to remove that exemption, culminating in a vote to that effect on 22 May 1713, aroused the fury of the Scots, who claimed that it violated the treaty, that it would ruin the Scottish farmers and brewers, and that it would deprive the Scot of his cheap drink. This pamphlet attempted to justify the action of the brewers who had refused to pay the tax in Scotland, and to appeal to the spirit of the union and the justice of the Queen.

195 A letter from a gentleman in Edinburgh to his friend in London, giving an account of the present proceedings against the Episcopal clergy in Scotland, for using the English lyturgy there. Edinburgh. 1711 (dated 19 November). $8^{\circ}$; 1-2 3-19 20 pp. (Ggorge Lockhart). L, E, O, InU

The freedom of the Episcopalians to use the English liturgy in Scotland was one of the more hented problems of the reign of Anne. Since the Greenshields decision in the House of Lords, the Episcopalians had assumed that they were free to act as they wished in this matter. The author of this tract, however, introduced the claim that Sir James Stuart, appointed Advocate General in the early fall of 1711 , had used every possible means to prevent this freedom of action. Stuart's zeal was held to be political in nature and to be illegal and oppressive. The timing of the pamphlet coincided with the growing conviction in England and in the Parliament that a toleration for Episcopalians in Scotland was necessary.

196 A letter from a gentleman in Edinburgh, to his friend in the country, concerning the way and manner in which the Abjuration Oath was sworn by the ministers, in the Shire of Edinburgh. Edinburgh printed by Mr. Robert Freebairn, and sold at his shop in the Parliament-Closs. 1712 (Bib. Linds., 28 October). $1 / 2^{\circ} ; 12 \mathrm{pp}$.

The Oath of Abjuration caused the Presbyterian ministers much trouble, and many felt able to swear the oath only with considerable personal misgivings. This letter did little to reassure those ministers who had attempted to take the oath with reservations, for it pointed out in rather plain language the deceit and evasion as well as the illegality and self-deception involved in such an attempt to "reserve" their consciences.

A letter from a gentelman in North Britain to the Right Honourable, the Earl of Seafield, concerning the improvement of the salmon fishing of North Britain. Edinburgh printed by John Reid in Liberton's Wynd. 1709. $1 / 2^{\circ}$; both sides. (J.H. $N, N, B$. ).

The Scots envied the Dutch the prosperity they had built upon the fishing industry, and wanted to promote a similar economy in Scotland. This tract promoted the salmon in- 
dustry, which was held to be underdeveloped, and sought assistance in curbing fishing practices held to be injurious to the salmon. Cf. No. 211 .

A letter from a gentleman in Scotland to his friend at London. London. 1712 (dated 29 January; published ca. 12 February). $8^{\circ}$; 1-2 3-16 pp. (Anonymous; although attributed by Moore to Defoe.) E, O, CtY, KU (arranged A1-3, 6-7, 4-5, 8)

Passage of a bill to relieve the Episcopalians in Scotland was discussed throughout England and Scotland in early 1712, and this pamphlet, written in late January, reflected the widespread interest in that controversy. The author argued that such a bill would have given the Episcopalians in Scotland much more standing than the dissenters in England enjoyed, and would have promoted discord and fears in Scotland among the Presbyterians who would see the union abandoned and Presbytery threatened.

199 A letter from a gentleman in Scotland to his friend in England, against the Sacramental Test; as inconsistent with the union, dangerous to the ecclesiastical constitution of North-Brittain; and to such parts of their civil constitution as are reserv'd to them; inconsistent with the civil interest of GreatBrittain in general; contrary to the design of our Saviour's institution of the Lord's-Supper, and to the doctrine of the Church of England. London: printed and sold by Benj. Bragg, at the Raven in Pater-Noster-Row. 1708 (dated 20 October; $H W L$, November). $4^{\circ}$; 1-2 3-32 pp. (“C.H."; sometimes attributed to Charles Leslie although content makes that attribution highly unlikely.) L, E, O

[variant:] . . North-Britain . . Great Britain . . The second edition corrected. London: printed and sold by Benj. Bragg, at the Raven in PaterNoster-Row. 1708. $4^{\circ}$; 1-2 3-32 pp. E, O, DFo, InU, MH

- [as second edition]. The third edition corrected. London, printed and sold by Benj. Bragg, at the Raven in Pater-Noster-Row, and sold by the booksellers of London and Westminster. 1709. $4^{\circ}$; 1-2 3-32 pp. L, O, CtY

Both before and after the union, the Scottish Presbyterians argued that the Sacramental Test, so fondly supported by the Anglicans, excluded strict Scottish Presbyterians from civil and military offices in England while the English Anglicans were not excluded from any offices in Scotland. This author sought to convince the Anglicans that it was in the best interest of all concerned with the well-being of a united Britain to suspend this act. It was a plea for moderation against high-church doctrines, and for this reason it $5 \mathrm{ccms}$ most unlikely that Charles Leslie would have had a hand in it. This tract was defended in No. 36.

200 A letter from a gentleman in the city, to his friend in the country. ... [1704]. $4^{\circ} ; 1-4$ pp. E, LU-G

By 1704, the Scots were deeply concerned with the problem of the exportation of wool cloth versus the exportation of raw wool for manufacture abroad. The Parliament, to encourage the manufacture of cloth, discouriged and prohibited the export of raw wool 
for a trial period, but Scottish manufacture was not advanced enough to utilize the wool or to pay the prices offered abroad; nor was woolen cloth from Scotland much prized. Arguments for and against the prohibition of the export of wool raged in the Parliament, and this tract was one of those which supported the export of wool over the export of cloth on the grounds that it was better to scll wool abroad than to have it rot at home.

201 A letter from a Member of Parliament to his friend in the country. Giving a short account of the proceedings of the Tackers, upon the Occasional and Self-Denying Bills, the Act of Security in Scotland, and other occurrences in the last session of Parliament. London: printed and are to be sold by the booksellers of London and Westminster. [1705] (HWL, March, April). $4^{\circ}$; 1-8 pp. (Humphry Mackworth.) L, O, InU, MH

- The fourth edition. London: printed for John Nutt near Stationers-Hall. $1705.1 / 2^{\circ}$; both sides. $\mathrm{KU}$

. The fifth edition. London: printed for John Nutt near StationersHall. $1705.12^{\circ}$; both sides. E, MH

While Scotland was not his primary concern, Mackworth, himself a "tacker," was forced to concern himself with problems which were Scottish in origin and with which the "tackers" were involved. The religious settlement in Scotland, the plight of the Episcopalians, the acts of the Scottish Parliament, and in particular the Act of Security, all were of great interest to the English Parliament. Mackworth used those issues and the votes of the "tackers" on them, to prove to his rcaders that this was a group of loyal subjects and patriots.

202 A letter from a member of the commission of the late General Assembly, to a minister in the country; concerning present dangers. [Edinburgh. 1707] (dated January). $4^{\circ}$; 1-8 pp. (Robert WyLlie.) L, E, LU-G, CtY

This "letter" reflected Wyllie's fears in January of 1707 for the safety and future of the Church of Scotland as it was defined by the terms of the Treaty of Union with England, which was ratified in that month. Wyllie accurately summarized the issues of greatest concern, and rightly prophesied the challenges, including a toleration for episcopacy, which would be made within the reign of Anne. Cf. No. 420.

203 A letter from a merchant to a countrey gentleman; touching matters of trade. [Edinburgh. 1704?]. $2^{\circ} ; 12-12 \mathrm{pp}$. E

This pamphlet is more of an economic survey of Scotland than a document in the AngloScottish debate, but it does illustrate the prevailing attitude toward the state of Scotland's economy, and relates that condition to England. Interestingly, most economists agreed that Scotland had declined in every respect since 1603, but the author conceded that much of the blame rested with Scots who had failed to utilize natural resources. The difficulties of encouraging commerce and manufacture in Scotland were made quite evident.

204 A letter from a Presbyterian minister in England, to his friend in Scotland; with respect to the invasion. [Edinburgh? 1708], (dated 13 March). $1 / 2^{\circ} ; 1-2 \mathrm{pp}$. L 
—. $1 / 2^{\circ} ; 12 \mathrm{pp} . \quad \mathrm{L}$

Rumors of a Jacobite invasion in Scotland in 1708 activated the government in London and pamphletecrs in general to rally the dissatisfied Scots who were thought to be insufficiently horrified by the prospects of a Jacobite in residence. This pamphlet appealed to the Scots Presbyterians to beware of a Catholic Pretender who would destroy their rcligion, and to unite all factions against that threat. Buchanan was called into the controversy to expound on the dangers of the French and their treatment of the Scots in the reign of Robert III.

205 A letter from a Presbyterian minister in the countrey, to a Member of Parliament; and also of the Commission of the Church concerning toleration and patronages. [Edinburgh?] 1703. $4^{\circ}$; 1-2 3-13 $4115-1920$ pp. (JoHN BANNATYNE.) L, E, O, LU-G, DFo

Bannatyne argued that a toleration to the ejected Episcopalians would only encourage them to challenge the established church, and that the restoration of patronage would give the patron too great a power to impose unwanted men upon the congregation. The arguments used were neither original nor clearly stated; the work would have appealed primarily to those who already were convinced.

206 A letter from a private gentleman to an English peer. [1707] (between March and May). $4^{\circ} ; 1-4 \mathrm{pp}$.

E

The English merchants claimed that foreign and Scottish merchants were importing goods into Scotland at a low duty for sale in England (which had a higher duty) after I May when all barricrs between England and Scotland would fall. This writcr contended that the charges were without foundation, that the great flect was minute at best, and that the goods supposedly stockpiled did not exist except in the minds of the English, who had overreacted. It was a call for common sense in the midst of an overly emotional outburst.

A letter from a Scotch gentleman to an English gentleman at London. Relating to Duke Hamilton's case. London: printed for John Morphew, near Stationer's-Hall. 1712 (ca. January-March). $8^{\circ} ; 1-23-8$ pp. DFo

The Scots were much incensed by the Hamilton case, in which the Duke of Hamilton was denied a seat in the British House of Lords even though he had been given a title in the new British pecrage. It was objected that he could not sit there by virtue of the Treaty of Union which established a set number of Scottish peers to be seated in any given Parliament. The Scots objected to this interpretation, arguing that they and they alone were therefore denied any hope of elevation into the British peerage. This tract sought to present the case for Hamilton and to object to the action of the British House of Lords.

208 A letter from a Scots factor at London, to a merchant in Edinburgh, concerning the proceeding of the House of Commons; to prevent the importation of wines and other goods from Scotland. [Edinburgh?, signed "London." 1707] (dated 17 April). $12^{\circ}$; one side. L

This tract was an "exposé" of Scots merchants who had imported goods from abroad into Scotland at low duty to await the disappearance of the barrier between Scotland and 
England on 1 May. The gains to be made by such men were considerable, and the English merchants were furious. The issue disappeared on 1 May when uniform duties were applied in both countries, but for a few weeks it was a most heated subject.

209 A letter from a Scots gentleman residing in London, to his friend in Edenborough. 1711. $8^{\circ}$; 1-2 3-38 pp. (George Lockhart.) E, InU [variant:] ... Edinburgh. 1713. $4^{\circ}$; 1-2 3-19 20 blk. pp. CtY

This fascinating analysis of Anglo-Scottish politics in the Parliament from 1708 through 1711 sought to impart to the Scots an awareness of the problems which the Scottish M.P.'s faced and the manner in which they were treated as a group. The author, after discussing all of the various acts and issues passed against the Scottish law and/or best interests, concluded with the observation that insofar as Scotland was concerned neither whig nor tory was preferable-they both acted with a total lack of concern for Scotland.

210 A letter from an English gentleman, containing, a description of Scotland, and particularly an account of the sufferings of the Episcopal clergy. np. nd. $12^{\circ}$; both sides. $\mathrm{E}$

This short paper began with a patronizing nod toward improvements in the food, cleanliness, and habits of the Scots, and then continued with an account of the suffering of the Episcopal clergy ejected in 1688-89, and left destitute in their old age. While giving the Scots credit for helping these men to the best of that country's limited ability, the author urged Englishmen to come to their aid.

211 A letter from E.C. to E.N. concerning the advantages of a fishery. Edinburgh, printed by James Watson, and sold at his shop, next door to the Red-Lyon, opposite to the Lucken-booths. $1709.2^{\circ} ; 12-4$ pp. (Signed E. C. Britannicus; sometimes doubtfully attributed to George Mackenzie.)

This tract was devoted exclusively to the fishing industry as it related to Scotland. The author, a Scot well-versed in that industry, argued that fishing had made the Dutch wealthy, and could do the same for the Scot if he pursued it with imagination and industry. Scotland was so well situated and equipped that all variety of fishing could be entered into. The author, having supported the union as a bencfit to Scotland, supported fishing as no less advantageous though the advantages of both may not have been immediately obvious. Cf. No. 197.

212 A letter from E. C. to E. W. concerning the union. [Edinburgh. 1706]. $4^{\circ}$; 1-16 pp. (George Mackenzie Earl of Cromarty.) L, E, O [title page reset]. InU

This letter was an attempt to persuade any Scots who were willing to listen that they would not lose more than they gained from the union. The objections dealt with were primarily political, constitutional, or psychological; economic matters did not form a significant portion of the debate. Mackenzie sought to neutralize many of the popular arguments against union: that Scotland's name would be lost, that her Parliament would be abolished, and that her laws would be altered. The arguments were direct and to the 
point: the union was not to Scotland's disadvantage. This was reprinted in No. 501, as was No. 378.

213 A letter from Mr. Hodges at London. To a Member of the Parliament of Scotland. Edinburgh, printed by the heirs and successors of Andrew Anderson, printer to the Queen's most Excellent Majesty. 1703 (dated 10 July). $4^{\circ} ; 1-3$ 4-8 pp. James Hodges. E, LU-G, CtY, DFo, MH

In this proposal, Mr. Hodges advanced the idea of an academy of war and universal learning which would be beneficial to Scotland's economy and military preparedness. $\mathrm{Mr}$. Hodges was to be headmaster.

214 A letter from Mr. Reason, to the high and mighty Prince the Mob. [Edinburgh. 1706] (Moore, 7 November). $4^{\circ} ; 1-8$ pp. (Daniel Defoe, althought often attributed to James Donaldson.) E, LU-G, CtY, MH

This tract sought to reduce the resentment felt by many in Scotland against the terms of the treaty agreed upon by the commissioners sent to negotiate with England. The author obviously telt that the treaty was not only the best which could be obtained, but that it offered many economic opportunities to the Scots, who had only to apply themselves to the potential offered by the treaty to want for nothing.

215 A letter from Mr. Scrupulous, to Trialogus concerning the union. Edinburgh the 21th October 1706. Edinburgh. 1706 (dated 21 October). $4^{\circ}$; $12-4$ pp. E, DFo

While proclaiming his general support for a firm and good union, the author was most concerned with presenting several objections to that union for which he sought answers. The questions included the loss by the nobility of their rights, economic dislocation brought on by the shift of government and revenues to London, and the dangers of having a national church protected by a Parliament dominated by Anglicans. The intent was to provoke response and to point out difficulties which the author saw in the union as it was advanced in the articles. This was written in answer to No. 489.

216 A letter from one of the Faculty of Advocates at Edinburgh, to his friend at London. London, printed for J. Morphew near Stationers-Hall. 1711 (ca. 15 August). $1 / 2{ }^{\circ}$; both sides.

$\mathrm{E}$

This tract is included more because of its condemnation of the Scottish legal system than for its references to Greenshields. However, on account of the degrec to which the twothe injustices of the legal system and the dismissal of the judgment against Greenshields by the British House of Lords-are related, this paper was retained. The author listed three occasions on which the same judge who tried Greenshields in Scotland had abused his authority in the interest of the Presbyterians. The implication was obvious.

217 A letter from Scotland, to a friend in London: containing a particular narrative of the whole proceedings against the Worcester and her crew, from her first arrival in Leith-Road, to the 20th of April 1705. In which the secret intrigues, and bloody designs of their prosecutors are detected and 
expos'd. Also an account of the sudden death of the principal evidence the day sentence was past; the prisoners behaviour after condemnation, and their manner of execution; with observations and reflections upon the whole. Publish'd by way of requital, for the many scandalous relations and reflections publish'd in the Flying-Post. London. 1705 (Moore, Defoe in the Pillory, 1 May). $4^{\circ} ; 1-23-32$ pp. (Anonymous, although sometimes attributed to Daniel Defoe.) L, E, CtY

The Green affair aroused great indignation in England, where the trial and execution of the Englishmen for piracy seemed to many to be a gross miscarriage of justice and a good illustration of Scotland's nature and law. This pamphlet, signed as if from Edinburgh, but published in London, did little to reduce tension; instead its author consciously sought to inflame public opinion against the Scots. The Scots did not emerge from this treatment with much reputation for either impartial justice or calm and rational action. As a source of information on the trial, the pamphlet is quite thorough and, while biased, presents the material clearly.

218 A letter from Scotland, to a Member of the House of Commons, against the eldest sons of Scots peers sitting in the house. London. 1709. $4^{\circ}$; 1-2 3-8 pp. $\mathrm{E}$

Eligibility of eldest sons of Scottish peers for election to the British House of Commons was a matter of considerable interest in the years immediately after the union, although the articles of that treaty had not addressed themselves to this point in law. This letter sought to fortify arguments that such sons were not by law eligible to the old nor to the new British Parliament.

219 A letter from the bishops of Scotland, to the bishops of England. [Edinburgh? 1712/1713]. $1 / 2^{\circ}$; both sides. E, DFo

The plight of the Episcopal clergy in Scotland always was an emotional issue, and this appeal to the bishops of England for assistance was certain to arouse considerable alarm and compassion. The "Letter" itself was moderate; the "Credentials to the Reverend Doctor Scott" which followed it was equally inflammatory and certain to stir the anger of the Presbyterians.

220 A letter from the borders of Scotland, concerning somewhat of agreement between a Scotch General Assembly and an English Provincial Convocation. By an Episcopal divine. London: printed for A. Baldwin in WarwickLane. 1702 (dated 21 September; published ca. 25 September; HWL, December). $4^{\circ}$; 1-8 pp. (White KennetT.) L, O, DFo

Debates between Episcopalians and Presbyterians in Scotland were an integral part of the religious life of that country, but only rarely did such controversy spill over into the English religious structure. This whig work sought to relate the problems within the polarized Anglican convocation to the Presbyterian church structure in Scotland, and to draw parallels between the two. Resistance to authority was the problem being examined. This was answered in No. 285. 
221 A letter from the Commission of the General Assembly, to the Presbytery of Hamilton, with the Presbytery's answer. [Edinburgh]. 1706 (answer dated 17 December). $1 / 2^{\circ}$; both sides. L, E, DFo

The protestations, petitions, and public demonstrations-whether encouraged or spontancous-had increased to such a tempo by December 1706, that the Moderator of the Commission of the General $\Lambda$ ssembly, William Carstares, felt compelled to admonish the presbyteries (Hamilton being onc of them which had protested) to restrain public disorders. The Moderator for Hamilton-Alexander Findlater--countered by disclaiming his responsibility for encouraging rabble-rousers, and protested the good faith and intentions of the presbytery to do its duty as was its right.

222 A letter from the country containing some remarks concerning the National Covenant and Solemn League. In answer to a late pamphlet, entituled, Lawful prejudices against an incorporating union with England. . . . Edinburgh. 1707 (dated 14 February). 4\% ; 1-2 3-12 pp. (William Adams.) E, InU

The author took exception to Webster's interpretation of the National League and Covenant, and to the obligations which he said it imposed upon all of that religion. First he denied Webster's contention that the covenant denied assistance to civil authority and asserted that there were numerous cxamples to the contrary. Moreover, the covenant had been stated in many different ways and with many different interpretations; and the one favored by Webster was not the only one. Moreover the fact that the union recognized the establishment of Episcopacy did not mean that it was forever established or that it was the only permissible structure. This answered Webster's No. 187. Webster replied in No. 373 and Adams responded to that work in No. 377.

223 A letter to a friend at Edinburgh from Roterdam; giving an account of the Scots affairs in Darien. ... [Rotterdam?] 1702. $8^{\circ} ; 1-34-171172 \mathrm{pp}$. JAMES BYres. E, MH

In this pamphlet James Byres attempted to rescue his character from charges made against him for his actions on the sccond Darien expedition. Byrcs, a prominent promoter of the company, was accused of numerous errors of judgment, and this tract presented an account of the entire course of events from August of 1699.

224 A letter to a friend, concerning the Oath of Abjuration. [1712?]. $4^{\circ}$; 1-12 pp. (George Ridpath.) CtY

The Oath of Abjuration strained the moderates in England and Scotland, and was an unpleasant matter for the conscicntious Presbyterian in Scotland to swallow. This author attempted to place the oath in perspective through an explanation of the English political and legal terms used in it. He also considered the political significance of oaths since 1688, with reference to the Pretender and to the succession. This author obviously was seeking to place the British Parliament in the best possible light. 
objections against it, with some remarks upon what has been written by Mr. H. and Mr. R. [Mr. Hodges and Mr. Ridpath]. Edinburgh. 1706 (dated 6 November). $4^{\circ} ; 1-23-44 \mathrm{pp}$. (JoHN CLERK, formerly erroneously attributed to Daniel Defoe.) L, E, CtY, DFo, MH

This straightforward "letter" in support of the union was by a Scot who sought to counter some of the objections to the union made in the autumn in Scotland. He addressed himself to some fourteen problems which he sought to answer in favor of union. The majority of them were those most common in the debate-dangers to the church, loss of sovereignty, inadequate security for the laws of Scotland, economic dislocation, and new taxes and duties. The author was completely for the union and sought through this tract to convince others. This was written in answer to Nos. 86 and 341, the latter of which answered No. 174.

226 A letter to a gentleman at London, concerning Mr. Adam Glass, late minister of the establish'd Church in Scotland, at the Parish of Aberlady. Who hath now conformed to the Church of England; and receiv'd orders from the Bishop of London. London: printed for A. Baldwin at the Oxford-Arms in Warwick-Lane. $1712.8^{\circ}$; 1-2 3-23 24 pp. L, O

In the emotional climate of 1712, the defection of a minister of the Church of Scotland to the Church of England and the parading of that individual in London could not fail to arousc comment from both camps. The Anglicans heralded it as confirmation of the superiority of Anglicanism, while the Presbyterians accused the Rev. Mr. Glass not only of heresy, but also of cheating and of practicing deceit upon the trusting merchants of Edinburgh. It was not a pleasant situation, nor is it a pleasant tract.

227 A letter to a gentleman in London from his friend in Edinburgh, occasion'd by the calumnies and groundless aspersions thrown upon the Revolution, and the Church of Scotland, lately printed in several letters, relating to the case of Mr. Greenshields; particularly that entitled The case of Mr. Greenshields, fully stated and discussed, in a letter from a commoner of NorthBritain to an English peer. London: printed for A. Baldwin, at the OxfordArms, in Warwick-Lane. [1711] (dated 6 March; published ca. 15 March). $8^{\circ}$; 1-2 3-15 $16 \mathrm{pp}$. $\mathrm{L}, \mathrm{O}$

The reaction to Greenshields' appeal to the Lords and to the debate in England over his case was predictable; the Scots Presbyterians were indignant and convinced that their church was in danger, yet a justification of their imprisonment of an Episcopal minister for using the English service was difficult. The British Parliament was predominately Anglican, and the activities of the ecclesiastical and civil authorities in Edinburgh was arbitrary. This tract reflects the confusion, anger, and frustration of the Scots Presbyterians caught in an almost indefensible position. This was an answer to No. 56, as was No. 33.

A letter to a L-d of the S-ss-n [Lord of the Session]. London. 1710 (dated 2 August; E ms. note, November). $4^{\circ} ; 1-23-12$ pp. George Lockhart.) $\quad \mathrm{E}, \operatorname{In} \mathrm{U}, \mathrm{MH}$

The Queen's decision to change her ministers from whig to tory worried some Scots who 
professed to see in that change a threat to the union. This author attempted to show that the change did not mean that Anne had deserted the union, nor did it mean that the Church of Scotland was in danger. It was an election pamphlet designed to encourage votes for the tories, and to reduce opposition which might interpret the change as antiScottish or Jacobite.

229 A letter to a Member of Parliament, anent the application of the 309885 Lib: 10 Shil: Sterl: Equivalent; with consideration of reducing the coin to the value and standard of England. [1706] (dated 20 December). $4^{\circ}$; 1-8 pp. (Anonymous, although formerly erroneously attributed to Daniel Defoe.) E, LU.G MH

The author of this tract was primarily interested in the fifteenth and sixteenth articles of the union, and the impact which the standardization of currency to the English level would have upon Scotland. He feared that the devaluation of the Scottish coin would lead to a loss in domestic and foreign trade, and in massive confusion for the Scottish merchant and farmer. He therefore sought to have the equivalent moncy paid first to cover losses in the recoining of the currency and only then to cover the public debt and the debts of those who had invested in the Scots East India Company. This was answered in No. 173.

230 A letter to a Member of Parliament, concerning manufacture and trade. $1704.4^{\circ} ; 1-23-8 \mathrm{pp}$. E, LU-G, DFo, MH

In order to promote the export of cloth manufactured in Scotland, Scottish law prohibited the exportation of wool from Scotland. Inferior Scottish cloth, however, could not be sold abroad. Thus both the manufacture of cloth and the production of wool suffered, while England, who also prohibited the export of wool, sold her superior cloth as and where she wished. The author sought a more flexible policy. He encouraged the importation of wool into Scotland and its re-exportation from there in evasion of English law. To prevent this, England might then consider a union; if not, Scotland still would have been the gainer.

231 A letter to a Member of Parliament, concerning the true interest of Scotland, with respect to the succession. [1703/1704]. $4^{\circ} ; 1-78$ pp. E, LU-G, DFo

The complicated debates in the Scottish Parliament over the succession to the throne there prompted this author to argue that the English were willing to discuss union only in order to encourage the Scots to settle the succession question as they had done. Once that issue was settled, the English would drop the union negotiation. He argued that the Scots should hold open their options on the succession, and should Jetermine whether England were serious or not on union and whether Scotland should go it alone or not. Certainly the author was not against union, but rather was dubious about England's willingness to treat in good faith with Scotland as an equal.

232 A letter to a Member of Parliament upon the 19th article of the Treaty of Union between the two kingdoms of Scotland and England. [Edinburgh?]. 1706 (dated 4 December). 4º $1-23-8$ pp. (George Mackenzie Earl of Cromarty.) E, O, CtY, DFo, MH, KU

[variant:] 1709 (with 9 lined through and 6 inscribed over it). InU 
The fate of the Scottish law and legal system after the union was a matter of considerable concern to Scots in 1706 . This pamphlet sought a compromise whereby the law might be protected from erosion by an English-dominated British Parliament, and not left to die of neglect and stagnation. Still another problem was the method by which judges would be appointed, and clearly the question of ultimate appeal. This author was in favor of a reformed and clearly defined-if also self-contained---legal system for Scotland.

233 A letter to one of the commissioners for the present union of England and Scotland. 1706 (dated Apr. ult.). $1 / 2^{\circ}$; both sides. E

This was a calm and reasonable discussion of the compromises which might reasonably lead to a union of England and Scotland. The author did not explore particulars, and thus avoided points of great controversy; but the outline which he proposed was similar to that which was finally adopted, and his reasoning most perceptive.

233A A letter to Sir J. P. Bart. [Sir John Pakington] A Member for the ensuing Parliament, relating to the union of England and Scotland. [London? 1702] (ca. 15 August). $4^{\circ}$; 1-8 pp. E, CtY, MH

[idem] The restoration of Episcopacy in Scotland, the only sure foundation for a lasting union with England in a letter to Sir J. P. Bar:. London. 1705. $4^{\circ} ; 12-8$ pp. L, E, O, LU-G, CtY

A letter to Sir J. P. Baronet, A Member of Parliament, relating to the union of England and Scotland. The second edition, with short additions. [1706?]. $4^{\circ}$; $1-8 \mathrm{pp}$. $\mathrm{E}$

As the title implies, the author addressed himself to Sir John Pakington, a tory Member of Parliament, in defense of the established Church of England, and against any union with Scotland which did not include the restoration of Episcopacy there and the protection of the established church in England. It was a simple and determined response to the idea of union, one which had great support among the high church Anglicans in England.

234. A letter to the author of the Review, concerning the collections for the Scots Episcopal clergy. London. 1708 (dated 15 May). 1/2 $; 12 \mathrm{pp}$. $\mathrm{O}, \mathrm{CtY}$

The plight of the ejected Episcopal clergy of Scotland-already acute at the accession of Anne-became ever worse as the men, although reduced in number, increased in age and want. The appeals to Englishmen to assist aroused considerable suspicion among those in England who feared their money would be used to assist the Jacobites in Scotland (who all too often were Episcopalian in religion). Defoe had raised doubts in the Review of 1 May, and this work sought to refute his charges. This was a topic of interest for several years.

A letter to the Right Honourable the Lord Privy Seal. SEE: No. 379.

235 Letters to the Right Reverend the Ld. Bishop of Carlisle. Occasioned by some passages in his late book of the Scotch Library. Wherein Robert the Third is beyond all dispute freed from the imputation of bastardy. A particu- 
lar account is given of King David's ransom, and of the hostages for the payment of the same. With several original papers relating to the Scotch affairs: And a grant for the liberties of Scotland. Letter I. London, printed for James Knapton, at the Crown in St. Paul's Church-Yard. 1702 (ca. 10 August). $8^{\circ}$; $(i-i v+$ folded facsimile insert) $1-5253-60$ pp. (Thomas Rymer.) L, E, O, DFo

Rymer responded in this letter to Nicolson's Scottish Historical Library, in particular to slights to Robert III, King of Scotland. Rymer argued for the legitimacy of that monarch; and although it might seem an academic question, neither the honor of the Scots nor the controversy over the succession to the thrones of England and of Scotland would allow it to pass unchallenged. The sequence of the debate was: Nos. $362,235,482,236,156,450$, $35,188,160,81,451,483,238,519,422$.

236 The liberty and independency of the Kingdom and Church of Scotland, asserted from antient records. Edinburgh, printed by Mr Andrew Symson. 1702 (Wodrow, the week before 16 November). $4^{\circ}$; (i-v vi blk.) 3-39 40 pp. Robert Sibbald. L, E, DFo

. To which is added, a speech at the proclamation of K. James VI. concerning the succession to the crown of England. Exactly printed from the original manuscript. Edinburgh, printed by Mr. Andrew Symson, for Mr. Henry Knox, Mr. David Freebairn, and John Vallange. $1703.8^{\circ}$; (i-iv) 1-2 3-39 40 pp. E

\section{1-2 (i-iv inserted) 3-39 $40 \mathrm{pp} . \quad \mathrm{KU}$}

- Second edition, enlarged; and divided into three parts. Wherein all the objections by Mr. Atwood, and others against the same, are fully answered; and the independency of both, prov'd from the choicest English historians, ancient and modern. Edinburgh printed by Mr. Andrew Symson. And are to be sold by Mr. Henry Knox in the Lucken-Booths: And Mr. Robert Freebairne in the Parliament Close. 1704. $4^{\circ}$; (i-iii iv blk.) 1-2 3-39 40 blk. 1-23 1 2-17 pp. E

Sibbald wrote this in part to refutc allegations made by Nicolson, and to prove that documents which Nicolson had reprinted in No. 362 were forged or faked. In particular, Sibbald sought to settle the question of the independence from England of the church and kingdom of Scotland, which he believed were threatened. In the heated atmosphere of England and Scotland in 1702, this could not be regarded as unimportant. The sequence of the debate was: Nos. $362,235,482,236,156,450,35,188,160,81,451,483,238$, 519,422 .

237 The liberty of Episcopal dissenters in Scotland, as it stands by the laws there, truly represented by a gentleman. London: printed, and are to be sold by A. Baldwin, near the Oxford-Arms in Warwick-Lane. 1703. $4^{\circ} ; 1.3$ 4-8 pp. (Anonymous, although formerly attributed to Daniel Defoe.) $\mathrm{L}, \operatorname{In} U$ 
This pamphlet was written from the point of view of an English dissenter eager to demonstrate the differences between the Episcopalians in Scotland and the dissenters in England. While the Episcopalians in the north had suffered in the past, the prevailing laws simply kept them out of the "publick churches" and did so because they were such determined Jacobites. The dissenters in England, however, were, and had been for some time, determined to exclude the Pretender, and therefore were not to be considered the same as those disestablished in Scotland.

238 The life of the reverend and learned Mr. John Sage. Wherein also some account is given of his writings, both printed and in manuscript; and some things are added, towards the clearing the ancient government of the Church of Scotland from the mistakes of a late author. . . . London, printed for Henry Clements, at the Half-Moon in St. Paul's Church-yard. 1714. $8^{\circ}$; (i-ii) 1-77 78 errata pp. (John Gillan.) L, E, O, KU

Gillan wrote to venerate Sage, but in the process he encountered Dalrymple as well. Sage was one of the more prominent Episcopal ministers of Scotland, who therefore resented the allegation that the Church of Scotland-the Presbyterian Church-had been free from bishops and from Roman infuences until late in its existence. The inference was that it was the Church of England which had introduced corrupting and corrupted elements into Scotland. The sequence of the debate was: Nos. 362, 235, 482, 236, 156, $450,35,188,160,81,451,483,238,519,422$.

239 The Lord Belhaven's speech in Parliament, the 15th day of November 1706 , on the second article of the treaty. [Edinburgh. 1706]. $4^{\circ} ; 1-8 \mathrm{pp}$. John Hamilton. $\quad$ L, E, LU-G, CtY, InU, MH

[variant:] The Lord Beilhaven's second speech in Parliament, the fifteenth day of November, 1706, on the second article of the treaty. [Edinburgh. 1706] (ca. 26 November). $1 / 2^{\circ}$; both sides. L, E, CtY, MH

In this speceh before the Scottish Parliament, Belhaven sought to delay or to prevent an incorporating union, and in particular to delay or prevent the acceptance of the second article of the treaty, on the succession. Rather, he urged that Scotland deal directly with Hanover in this Parliament, and make with Hanover whatever arrangements would be necessary to protect the rights, liberties, sovereignty, and independence of Scotland. To him, the acceptance of England's terms on the succession would be the least protection possible for Scotland. This was answered in No. 29.

240 The Lord Belhavens speech in Parliament, the 17th. of July 1705. [Edinburgh. 1705]. $4^{\circ} ; 1-78$ pp. John Hamilton. L, E, LU-G, CtY, DFo, $\mathrm{MH}$

[variant:] . . . in the Parliament of Scotland: on the 17th day of July last past, 1705. upon unanimity, limitations and a treaty, \&c. Dublin: re-printed by Francis Dickson in Smock-Alley. 1705. $4^{\circ} ; 12-4$ pp.

In this published speech, Belhaven urged unity among all Scots as an alternative to a discord which England might exploit. In times of disunity, England had imposed herself upon Scotland; but if Scotland were united, she would have no need for imposing limita- 
tions upon the Queen, nor for excessive demands to be made upon England.- Rather, the best interest of Scotland then could be protected from a position of strength.

241 The Lord Beilhaven's speech in Parliament the second day of November 1706. On the subject-matter of an union betwixt the two Kingdoms of Scotland and England. [1706] (before 14 December). $4^{\circ} ; 1-12 \mathrm{pp.} \mathrm{JoHN}$ Hamilton. L, E, LU-G, CtY, MH

$$
4^{\circ} ; 1-16 \text { pp. (p. 13, speech of } 15 \text { November, No. 239). E, }
$$

MH (pp. 13-16 only)

\section{MH}

$4^{\circ} ; 1-20$ pp. (p. 16, speech of 15 November, No. 239).

E,

[variant:] ... speech in Parliament Saturday the second of November, on the subject-matter of an union. . . 1706. $4^{\circ} ; 1-23-24$ pp. L, E, InU

[variant:] ... speech in the Scotch Parliament, Saturday the second of November, on the subject-matter of an union.... 1706. $8^{\circ} ; 1-23-16$ pp. L, E, O (has two issues of this edition), LU-G, CtY, InU, MH, KU

Of all the speeches made against the union in the Scottish Parliament, none achieved the fame of this one by Lord Belhaven. In it he envisioned a Scotland reduced on every level to a most melancholy state- a church abandoned, a kingdom reduced to servitude, a nobility stripped of its power. It was a most emotional speech, intended in part at least for the express purpose of whipping up public sentiment against the union. It was answered in Nos. 88 and 398, as well as in No. 30, from which stemmed the following debate: Nos. 241, 30, 525, 355, 332, 374, 118.

242 The Lord Haversham's speech in the House of Peers, on Saturday, February 15. 1706/7. London: printed and sold by B. Bragg, at the Raven in Pater-Noster-Row. 1707. $4^{\circ}$; $1-4$ pp. John Thompson. L, E, O, CtY, DFo, InU

[variant:] ... February 15. 1709/7 (!). E

$$
\text { . np. nd. } 12^{\circ} \text {; both sides. E, LU-G }
$$

Haversham's opposition to the union was based upon many objections to the articles as they were presented to the English Parliament. The two religions were, he thought, incompatible, and a union of them into one impossible. The English constitution also was too magnificent (but also too English) to be diluted with Scottish influences, which would upset it. The rights of the Scottish peers had been abridged as well, and the Presbyterian Church certainly was not secured. The union, moreover, was incomplete, for the Scots had reserved aspects of their ancient constitution. It was, to Haversham, a most imperfect union and one which he therefore opposed. This tract wals answered by Nos. 256, 328, and 34 .

The Lord Haversham's speech in the House of Peers, on Thursday, November 23. 1704. London: printed for B. Bragg in Ave-Mary-Lane. 1704 (HWL, November). $4^{\circ}$; $1-4$ pp. John Thompson. L, CtY, DFo 
[variant:] .. Thursday November 22 (1) 1704. Edinburgh, re-printed by the heirs and successors of Andrew Anderson, printer to the Queens most Excellent Majesty. $1704.12^{\circ}$; both sides.

$\mathrm{E}$

True to his reputation, Haversham's speech was controversial. In a few brief paragraphs he slighted Marlborough, accused Admiral Rooke of cowardice, insinuated that Anne and the ninistry had broken trade, debased coinage, and left England defenseless, and finally insulted Scotland and the ministry there. With reference to Scotland, he questioned the integrity of the Scots ministry, accused them of insincerity and deceit in the Act of Security, and cast slurs upon both the Scots nobility and gentry. It was a peevish and troublesome speech. Cf. Nos. 155, 322, and 326, all of which answered it.

244 A loud call for help and sympathy; or, a sermon on Acts XVI, 9, 10. Wherein divers arguments are offered to perswade and excite to contribute, for advancing the noble and pious project of propagating the knowledge of Christ in the Highlands and Islands of Scotland. Preached on Thursday, September 8. 1709 ... With some small addition. Edinburgh, printed by the heirs and successors of Andrew Anderson, printer to the Queens most Excellent Majesty. 1710. $4^{\circ} ; 1-23-10$ pp. James Clark. E

In the reign of Anne, the Highlands of Scotland were regarded as little different from the wilderness of America: both received the attention of those in Scotland and England who sought to spread Christian knowledge (as they saw it) among the heathen. This sermon preached in Edinburgh appealed to those who wished to extirpate Catholicism and superstition from the Highlands, and to introduce the people to the wonders of civilization.

245 A manifesto, asserting and clearing the legal right of the Princess Sophia, and her issue, the serene house of Hanover, to the succession of Scotland. Re-printed in the year $1704.4^{\circ} ; 1-23-8 \mathrm{pp}$. $\mathrm{E}$

In 1704, the Hanoverian succession in Scotland was neither as secure as in England nor as popular with the Scots as with the English. This pamphlet sought to make the Hanoverians known to Scotland and to present them in as favorable a light as possible. The entire history of the succession since 1688 was reviewed in order to build a case for the Hanoverians.

246 Marlborough still conquers: or, union hath got the day. A poem, upon the late victory obtained by the Prince and Duke of Marlborough; and union of the two kingdoms. ... London: printed by D. Rogers, and sold by John Morphew near Stationers-Hall. 1708. $2^{\circ}$; 1-2 3-12 pp. JoHn GaYNAM. $\mathrm{O}$

. London: printed by $\mathrm{H}$. Hills, in Black-fryars, near the Waterside. $1708.8^{\circ} ; 1-45-16$ pp. $\quad$ L, E, O, Cty, DFo, InY, MH

This three-part poem ranks among the better efforts inspired by the union. After a celebration of the triumph of Protestantism over Catholicism, it lauded the association of union and moderation which led to peace and love, and finally the victories of Marl- 
borough based upon unity at home. Anne was praised as the wise monarch able to bind together all of these into a glorious reign.

247 The massacre of Glenco. Being a true narrative of the barbarous murther of the Glenco-Men, in the Highlands of Scotland, by way of military execution, on the 13th of Feb. 1692. Containing the Commission under the Great Seal of Scotland, for making an enquiry into that horrid murther: the proceedings of the Parliament of Scotland upon it: the report of the Commissioners upon the enquiry, laid before the King and Parliament. And the address of the Parliament to King William for justice upon the murderers. Faithfully extracted from the records of Parliament. And publish'd for undeceiving those who have been impos'd upon by false accounts. London, printed, and sold by B. Bragg, at the Blue-Ball in Ave-Mary-Lane. 1703 (dated 1 November; published ca. 30 November). $4^{\circ}$; $1-23-32$ pp. (George Ridрath.) L, E, DFo, InU, MH

- The second edition. London, printed, and sold by $\mathrm{B}$. Bragg, at the Blue-Ball in Ave-Mary-Lane. 1704 (ca. 4 April). $4^{\circ}$; 1-2 3-31 32 blk. pp. E

The Massacre of Glcnco was one of the first publications to present all of the official documents relating to that event and to the investigation which followed it in Scotland. News of Glencoe had spread through England, France, and Scotland early in the reign of William, and few in London would have been unaware of it. Since Scots were both the killed and the killers in that massacre, it was not easy to make it an Anglo-Scottish affair, but undoubtedly many so believed. Of course, the fact that it had happened at all aroused considerable dissatisfaction with the government as it was established in 1692. Compared to other issues, however, Glencoe was not a major issue in the reign of Anne.

248 Memoirs concerning the affairs of Scotland, from Queen Anne's accession to the throne, to the commencement of the union of the two kingdoms of Scotland and England, in May, 1707. With an account of the origine and progress of the design'd invasion from France, in March, 1708. And some reflections on the ancient state of Scotland. To which is prefix'd an introduction, shewing the reason for publishing these memoirs at this juncture. London printed: and sold by the booksellers of London and Westminster. 1714 (Kennett, 20 July). $8^{\circ}$; i-ii iii-xxx 1-304 321-348 $49350-403404$ blk. $405-420$ pp. (George Lockhart.) L, E, O, DFo, InU (lacking pp. 405-420), MH, KU (lacking pp. 405-420)

. London printed: and sold by J. Baker, in Pater-Noster-Row: and the booksellers of London and Westminster. 1714. $8^{\circ}$; i-ii iii-xxx 1-304 321-403 404 blk. $405-420$ pp. InU (lacking pp. 405-420), MH, KU

. London printed: and sold by J. Baker, at the Black-Boy in PaterNoster-Row. 1714. $8^{\circ}$; i-ii iii-xxx 1-304 321-403 404 blk. 405-420 pp. KU The second edition. To which is added an appendix. London 
printed: and sold by J. Baker at the Black-Boy in Pater-Noster-Row. $1714.8^{\circ}$; i-ii iii-xxx 1-304 321-403404 blk. 405-420 pp. L, E, O, InU, KU

. The third edition. To which is added an appendix. London printed: and sold by J. Baker, at the Black-Boy in Pater-Noster-Row. 1714. $8^{\circ}$; i-ii 1-304 321-403 404 blk. $405-420$ pp. L, E, O, KU

This extremely long and complicated account of the government and politics of Scotland from the accession of Queen Anne, concentrated on the union, and on the invasion of Scotland in 1708 , as seen by one who usually was described as the rankest of Jacobites. Taken as such, it was an interesting analysis of Jacobite politics and an equally fascinating account of the personalities involved. However, it must be taken with grave reservations, for Lockhart saw history from one point of vicw only. There werc two "indexes" to the work, No. 183, and Thomas Burnet's A Protestant Index to Mr. Lock-m's Memoirs, concerning the affairs of Scotland, which was published after the death of Anne.

249 Memoirs of the affairs of Scotland, containing a full and impartial account of the Revolution in that kingdom begun in 1567. Faithfully publish'd from an authentick MS. By Her Majesty's Historiographer for the Kingdom of Scotland.... London, printed and sold by the booksellers of London and Westminster. 1706 (before 15 July; HWL, June, July). $8^{\circ}$; (I-XVIII) i-xxxix xl blk. 1-209 211210 212-314 $115316-333335334336-378379$ errata 380 pp. (David Crawford.) L, E, O, DFo, InU, KU

No history of two kingdoms so closely intertwined as England and Scotland is without controversy. In 1706, a history of Scotland from 1566 to 1581 obviously would reflect upon Mary as well as upon Elizabeth, and would arouse defenders on both sides. Crawford sought to defend Mary against historians, including Buchanan, and his treatment of the material left little doubt of his lack of objectivity.

250 Memoirs of the Lord Viscount Dundee, the Highland-clans, and the massacre of Glenco: with an account of Dundee's officers, after they went to France. By an officer of the army. ... London. 1711. $4^{\circ}$; i-iii iv-ix $x 1-74 \mathrm{pp}$. (With the exception of the account of the officers after they went to France, almost certainly by Chardes Leslie.) L, E, O

London: printed for Jonas Brown, at the Black Swan without Temple-bar. 1714 (ca. 6 May). $8^{\circ}$; i-ii iii-xiii xiv blk. xv xvi blk. 1-132 pp. $\mathrm{L}, \mathrm{O}, \mathrm{DFo}, \mathrm{MH}$ (all lacking pp. $x v-x v i$ ); KU

The Jacobite cause in Scotland demanded that historical events there be placed in a perspective which would enhance the chances of the Pretender, and would advance the Episcopal cause. Scottish pride in Dundce's victory at Killiecrankie could be matched with the horror felt by cvery Scot at the violation of Macdonald hospitality. The Presbyterians and Cameronians thus joined the Campbell clan and William III among those who could be classed as cnemies of the rightful king. This compilation of accounts is particularly valuable for its matcrial on Glencoe. 
two kingdoms, humbly offered to the consideration of the Commissioners appointed for that end. London, printed and are to be sold by J. Nutt near Stationers-Hall. 1702 (after 10 November; $H W L$, January 1703). $4^{\circ} ; 1-4$ 5-9 10 blk. 11-12 13-16 pp. (starting on p. 11: "Memorial shewing the advantages the kingdom of Scotland may have by the undertaking and improvement of fishings for export, whether by societies, or singular persons . . 1700"). (J.B.; $\mathrm{MH}$ ms. attribution to "Colonelle John Buchan of Cairnbulge".) L, E, O, LU-G, CtY, DFo, MH

The author urged either union or separation as the best way in which Scotland could advance her economic self-interest. Fishing was the primary concern of the author, who saw it as the basis for Dutch wealth and who urged its development in Scotland. According to the author, union had been prevented in the past in part by fears in the Netherlands of competition from a united fishing industry in England and Scotland.

252 A memorial concerning the disorders of the Highlands, especially the northern parts thereof, and the Isles of Scotland. With an account of some means, by which the same may be redressed and prevented, and how religion and vertue may be promoted in these parts. Edinburgh. $1703.4^{\circ} ; 1-23-88$ 10 pp. (James Kirkwood.) E, LU-G, DFo

This appeal for financial assistance for the Highlands was a part of a long campaign by Kirkwood to build schools and libraries, and to bring about religious and intellectual reformation in the area. Funds to build libraries, to pay schoolmasters, and to pay for the costs of boarding Highland boys all were sought, but without much success. In its religious aspects, this attempt to spread the Protestant faith to the Highlands was similar to many contemporary movements to reform manners and to spread Christian knowledge.

253 Memorial concerning the state of the manufactures before and since the year 1700, at which time the laws concerning trade and manufactures were revived and increased: as also, some remarks upon the arts used for eluding these laws, humbly offered to His Grace, and the Honourable Estates of Parliament. [Edinburgh? 1703?]. $2^{\circ} ; 1-33$ pp.

This economic paper illustrated the problems faced by Scotland before the union; her wool manufacture was small and new and not yet particularly competitive. Her laws encournged it through controls over exports of wool. This paper confronted those who expected results too soon, and those who favored repeal. It urged patience, and exposed several means being used to evade the law which should be halted.

254 A memorial to the nobility of Scotland, who are to assemble in order to choose the sitting peers for the Parliament of Great Britain. Edinburgh, printed by the heirs and successors of Andrew Anderson, printer to the Queens most Excellent Majesty. 1708 (before the elections in May). 4 ; 1-2 3-16 pp. (Daniel Defoe.) E, CtY, DFo, MH

The elections of 1708 were the occasion of this political pamphlet addressed to the Lords of Scotland, urging them to support the established government in the elections. The 
author stressed the advantages of the union and lamented the divisions and party strife which threatened the well-being of Scotland. The author urged the Lords to rise above such strife in the election of peers to the Parliament, and suggested that they should sit in the Lords through a system of voluntary rotations. In its arguments this is a companion piece to Scotland in danger, No. 350.

255 The merites of piracie or, a new song on Captain Green and his bloody crue: to the tune of, My virgins treasure. [Edinburgh. 1705]. $12^{\circ}$; one side. L

The case of Captain Thomas Green, accused of piracy and executed under Scottish law, further embittered Anglo-Scottish relations in 1705. This song portrayed Green and his crew as pirates, who deserved nothing better than what they had received. It was doggerel set to music; the sentiment definitely was not on the side of Captain Green, who enjoyed considerable popularity in England if not in Edinburgh.

256 A modest vindication of the present ministry: from the reflections publish'd against them in a late printed paper, entitled, The Lord Haversham's speech, \&c. with a review and ballance of the present war. Evincing, that we are not in such a desperate condition as that paper insinuates. Humbly submitted to the consideration of all, but especially to the Right Houourable (1) and the Honourable, the North-British Lords and Commoners. By a wellwisher to the peace of Britain. London. 1707 (Lee; Moore, probably early summer). $4^{\circ}$; (i-ii) 1-14 pp. (Daniel. Defoe.) O, CtY

Union Coffee-House on Cork-Hill. 1707. $4^{\circ} ; 12-12 \mathrm{pp}$. CtY

This reply to Lord Haversham's speeches of 15 February and 19 November 1707, attempted to answer points raised in both speeches. It therefore had a decidedly mixed tone and at best answered two confused speeches in a confusing reply. The February speech (No. 242) was on the union itself, while the November speech was more an attack upon the ministry as a whole; Scotland had entered that speech only indirectly. This reply combined points relative to Scotland from the two speeches and answered them as a defense of the treaty and the action of the government. The February speech also was answered by Nos. 328 and 34 .

257 Money and trade considered, with a proposal for supplying the nation with money. Edinburgh, printed by the heirs and successors of Andrew Anderson, printer to the Queen's most Excellent Majesty. 1705. $4^{\circ} ; 1-34-120$ pp. (John Law.) L, E, LU-G, CtY, MH

This tract was as much concerned with abstract economic theory as with an analysis of Scotland's commercial and industrial needs; but Law did use Scotland as an example. He was concerned generally with her financial problems, and this tract reflected that interest.

258 More short-ways with the Dissenters. London. 1704 (ca. 28 April). $4^{\circ}$; (i-iv) 1-24 pp. (Daniel Defoe.) L, O, CtY, InU, MH

Scotland was not a major concern of Defoe in this pamphlet, and it is for scattered pas- 
sages and not for the primary theme that it is included. For comparison, Defoe contrasted the Episcopalians in Scotland with the dissenters in England. But he noted that the Episcopalians had suffered little during the reigns of William and of Anne, that they had had few legal restraints placed upon them, that they were really a recent and imported religion from England, and that they had been particularly oppressive when forced upon the Scots Presbyterians in previous reigns. In short, the English dissenter was decidedly different from the Scots Episcopalian.

A morning's discoursc of a bottomless tubb, introducing the historical fable of the oak and her three provinces; or, transactions in government among trees: being historical and satyrical remarks on passages in some late reigns; mix'd with comical dialogues in the jargon or brogue of several nations, viz. French, Irish, Scotch, Welsh, \&c. Written by a lover of the loyal, honest, and moderate party. London: printed for John Morphew near Stationer's Hall. 1712. $8^{\circ}$; (i-viii) $1-160$ pp. L, CtY, MH

The "fable" of the oak and her three provinces only occasionally involved Anglo-Scottish affairs as such; but to the extent that the fable recounted the history of the reigns of William and of Anne, it did include Scotland and it did make some interesting observations upon the union.

260 [Begin:] My Lord Chancellor, It was my humble opinion on the beginning of this session. . . . [E described as "Specch in the Parliament of Scotland upon the union and upon limitations 1702/3"]. [1702/1703?] $4^{\circ}$; 1.8910 blk. pp. (Grorge Mackentie Earl of Cromarty.) E

This speech by Cromarty attempted to come to terms with the questions of a union, Scottish anger at England, and the succession. His speech was divided into three areas of interest: trade, limitations, and treaty. On the matters of trade and limitations, he felt that both could be best decided after the third, the treaty, had been determined. If Scotland and England decided, as he hoped they would, on an incorporating union, then such matters as trade and limitations might best be left to that time and circumstance.

261 A narrative of the late treatment of the Episcopal ministers within the city of Edinburgh since March last 1708. Until their imprisonment in July thereafter, with their circumstances and defences together with some reflections upon the same. With a postscript. ... London, printed and sold by John Morphew near Stationers Hall. 1708. (HWL, November; before 27 November). $4^{\circ}$; (i-viii) $1-3334 \mathrm{pp}$.

$\mathrm{E}, \mathrm{O}, \mathrm{CtY}, \mathrm{InU}$

The Episcopal ministers in Scotland increasingly were the subject of dispute in Scotland and in England, for the Anglican church viewed their condition with mounting alarm. Their initial expulsion from their charges, and the subsequent poverty, and perhaps oppression, under which they resided, made them objects of pity to Anglicans if not to the Scots Presbyterians. This narrative presented a picture of them to the English and demonstrated how inhumanely and cruelly they were being treated. This was answered in No. 356. 
the acknowledgement of sins, and engagement to duties: as they were renewed at Douglass July 24th 1712. With accommodation to the present times. Together with an introductory preface, containing a narrative of the manner of the action, and the scope of the sermons preached before it, and obviating some of the most material objections that are made against it. . . [Edinburgh?]. 1712. $4^{\circ} ; 1-23-4012-596061-6461-626364$ pp. L, DFo

Although more of an internal religious document than one directly involved in AngloScottish affairs, this tract sought a reconciliation between the requirements imposed upon believers who took the Solemn League and Covenant, with the realities of religious and political life in a united England and Scotland. The author was not so much against union as he was for a renewal of the enthusiasm and spirit of the original covenant.

263 National union a national blessing. A sermon preach'd at St. Margaret's Church in Lyn-Regis, on the first of May, 1707. Being the day of publick thanksgiving for the happy union of England and Scotland. London: printed for John Wyat, at the Rose in St. Paul's Church-Yard. 1707 (published before 27 May). $4^{\circ}$; (i-iv) 1-21 22 pp. Thomas Pyle. E, O

Pyle took great pride in the fact that this was a union of law and not of the sword. He preferred religious unity, but he accepted this union as better than nothing, and as progress toward such a unity of religions. Overall, this was a moderate sermon.

264 The new association of those called, moderate church-men, with the modern-whigs and fanaticks, to under-mine and blow-up the present church and government. Occasion'd by a late pamphlet, entituled, The danger of priest-craft, \&c. With a supplement, on occasion of the new Scotch Presbyterian Covenant. By a True-Church-Man. . . . Printed and sold by the booksellers of London and Westminster. 1702 (supplement dated 5 November; HWL, November). $4^{\circ}$; 1-30 31-32 1-10 pp. (Charles Leslie; sometimes incorrectly attributed to Henry Sacheverell.) CtY, InU, MH (lacking pp. 1-10 [supplement])

. The second edition corrected. Printed and sold by the booksellers of London and Westminster. 1702 (before 22 December). $4^{\circ}$; (i-ii) 1-22 1-10 pp

[variant of second edition:] Dl incorrectly as Fl.

$\mathrm{O}$

The third edition corrected. Printed and sold by the booksellers of London and Westminster. 1702. $4^{\circ}$; (i-ii) $1-211-910 \mathrm{pp}$. L, E, O, $\mathrm{CtY}, \mathrm{MH}$

[variant of third edition:] Printed and sold by the booksellers of London and Westminster. $1702.4^{\circ}$; (i-ii) $1-211-88$ pp.

$\mathrm{KU}$

[variant of third edition:] . . moderate-church-man. . . Printed and sold by the booksellers of London and Westminster. $1702.4^{\circ}$; (i-ii) 1-21 1-8 8 pp. L 
. The fourth edition corrected. Printed and sold by the booksellers of London and Westminster. 1705. $4^{\circ}$; (i-iv) 1-30 31-32 pp. E, O, CtY, DFo, InU, MH

[yariant:] ... new Scotch Presbyterian Covenant. Together, with an appendix, containing two clauses of a Parliament ordnance for the establishment of the directory, with the opinions of some of the most eminent Dissenters themselves concerning toleration: and the comfortable fruits of being exempted from penal laws and statutes. By a true church-man. Dublin: printed by Daniel Thompson in Cole's Alley, Castle-street. 1714. $8^{\circ}$; (i-ii) 1-70 pp. $\mathrm{O}$

While the New Association itself was concerned primarily with the dissenters, and only briefly and indirectly with the Scots and the Presbyterians, the Supplement (the drop title was: "A supplement on occasion of The New Scotch Presbyterian Covenant," and it is occasionally recorded as a scparately published tract) was a violent and irrational diatribe against the Scots Presbyterians who were accused of being enemies of the Anglican Church and of monarchy.

265 The new association. Part II. With farther improvements. As another and later Scots Presbyterian-Covenant, besides that mention'd in the former part. And the proceedings of that party since. An answer to some objections in the pretended D. Foe's explication, in the reflections upon the shortest way. With remarks upon both. Also an account of several other pamphlets, which carry on, and plainly discover the design to undermine and blow-up the present church and government. Particularly, the discovery of a certain secret history, not yet publish'd. With a short account of the original of government. Compar'd with the schemes of the republicans and whigs. Printed and sold by the booksellers of London and Westminstcr. 1703 (HWL, April, May). $4^{\circ}$; (i-ii) 1-361-22 pp. (Charles Leslie.) L, O, DFo, MH

[variant:] 12-29 $2631-361-22 \mathrm{pp}$. L, DFo

[variant:] (i-ii) $12-253027-292631-361-2223$ errata 24 blk. pp. $\quad$ E, DFo (lacking pp. 23-24)

. The second edition with additions. Printed and sold by the booksellers of London and Westminster. $4^{\circ}$; (i-iv) 1-30 $1332-62$ pp. 1705 . E, $\mathrm{CtY}, \mathrm{MH}$

The controversy over dissenters attracted a large and talented group of writers, including Leslie and Defoe, but the main emphasis was upon England and the dissenters there. Herc, however, Leslie also attacked the Presbyterians in Scotland; to him they were republicans, fanatics, rebels, and murderers of the King. To him any revival of Presbyterian fervor was a sign of rebellion and sedition. 
to vouch for the Caledonian Company, after that gentleman hath been persecuted by them these thirteen months past for vouching against them. ... London, printed for any body, and sold by the booksellers of London and Westminster. 1701. $4^{\circ}$; 1-2 3-5 4 7-14 pp. (Walter Harris.) LU-G, MH

This tract sought to counter charges in Ridpath's The Flying Post, made by one of the captains on the first voyage to Darien, that it was English proclamations against intercourse with the Scots that had ruined the expedition. See also No. 172, which appeared before this tract.

267 The Oath of Abjuration considered, both as to the lawfulness and expediency of it's being taken by the ministers of the Church of Scotland, in a letter to a friend. Edinburgh. 1712 (between 20 March and 2 October). $4^{\circ}$; (i-ii) 1-26 pp. E, O

This pamphlet was written with considerable moderation as well as with good sense. It sought to encourage all but the most scrupulous of Presbyterians ministers to take the oath in good conscience. While there indeed were aspects of it which might seem detrimental to the Church of Scotland, and while there also was wording in it which might cause the most exacting in such matters to scruple, still the oath was suggested by constituted authority. It should be taken with good intentions and should imply the same from those who had formulated it. In sum, there was less in it to harm than to help, and it therefore should be accepted. This was answercd in No. 522.

268 The Oath of Abjuration, considered, in a letter to a friend. [Edinburgh]. 1712 (dated 20 March; E ms. note, printed September). $4^{\circ} ; 12-40$ pp. (RoBert Wodrow.) E, O

This author had many doubts about the Oath of Abjuration and his fears were such that he found compliance with this oath most difficult. The problem in part was semantic, for the author was a Scot who claimed that the oath was created in England for Englishmen and that its wording reflected the religious and legal circumstances of that country and not of Scotland. Moreover, he felt that it was not in the best interest of the Presbyterian Church; nor did it clarify the responsibility of ministers who looked to God and to the state if the succession were altered to something other than the present expected Hanoverian solution. While not a Jacobite, the author certainly did stick close to that line on matters both religious and political.

269 The Oath of Abjuration displayed, in its sinfull nature and tendency, in its inconsistency with Presbyterian principles and covenants; the security it affords to the Church of England. Together with some remarks upon the evasions and explications offered thereupon, by the ministers who took it, shewing them to be contradictory to the sense of the Oath, and meaning of the imposers. Being the copy of a letter sent to one of the jurant-ministers of the Presbytery of Dumblane. . . . Re-printed 1713 (dated 17 November 1712). 4; $12-35$ 36 blk. pp. (Hugh ClaRK.) E

This writer was one of the more orthodox and extreme Scots Presbyterians who felt that the taking of the oath would bind them to illegal and immoral acts, and to interpretations 
of a religious as well as a political nature unacceptable to then. The wording of the oath undoubtedly complicated matters, for it contained not only idcological hair-splitting, but also English terms foreign to Scots. This author, however, was as interested in castigating his colleagues in the church who had taken the oath as he was in expressing his doubts. He either wanted an excuse not to abjure, or to support his contention that its wording and content were religiously unacceptable. Cf. No. 421.

270 The Oath of Abjuration enquir'd into: in a letter to a friend. [1712] (dated 29 April; E ms. note, printed September). $4^{\circ}$; $1-1516$ pp. (Allan LOGAN.) E

The Oath of Abjuration tormented the Presbyterian Church in Scotland in a way few other political or religious problems did in the reign of Anne. The Act of Union, followed first by the oath and then by the Patronage Act, frightened many who believed the church to be in danger. This author was one of those for whom the actions of the past years had simply been too much. He lashed at the form and content of the oath, and at the actions of those in the church who over the past years had sacrificed the interest of the church to expediency and opportunism. Cf. No. 421 .

271 The Oath of Abjuration no ground of separation. By a lover of truth and peace. Recommended by several non-jurant ministers. Kirkbride, printed by Robert Rae. $1713.8^{\circ}$; 1-2 3-45 46-48 blk. pp. (Alexander Robeson.) E

The author of this tract was a minister who sought reconciliation, and who feared that there might be a break within the Church of Scotland over the taking of the Oath of Abjuration. He attempted to show that the oath was not sufficient cause for such fragmentation, and that all Presbyterians had too much in common to risk the destruction of the faith over the oath. This was answered in No. 522 .

272 The Oath of $\Lambda$ bjuration, set in its true light; in a letter to a friend. Edinburgh, printed by the heirs and successors of Andrew Anderson, printer to the Queen's most Excellent Majesty. 1712. $8^{\circ} ; 12$ blk. 34 blk. 5-6 7-29 30 pp. (Str James Stewart.) L, E

The imposition of the Oath of Abjuration upon the Presbyterians as well as upon the Episcopalians of Scotland in late February 1712, provoked a furious response from the Presbyterians, who were required to swear that the monarch should be of the Church of England. This pamphlet sought, in a legalistic way, to interpret the terms of the onth and to soothe the Presbyterians. The author paid particular attention to differences in terminology and to varied interpretations of words and phrases; but the impact no doubt was limited. This was answered in No. 522, and in Queries to the Presbyterian ministers of Scotland, by David Freebairn.

Observations made in England, on the trial of Captain Green. SEE: No. 274. 273 Observations on the fifth article of the Treaty of Union, humbly offered to the consideration of the Parliament, relating to foreign ships. [Edinburgh. 1706] (The fifth article was read in the Scottish Parliament on 21 November). $4^{\circ}$; 1-4 pp. (Daniel Defoe.) L, E, CtY, DFo, InU 
According to the fifth article of the Treaty of Union, all ships in Scottish trade, owned by foreigners at the time of the signing of the treaty, remained foreign bottoms. Since many ships trading in south-east Scotland were Dutch or partly Dutch-owned, the dislocation was considerable. The author sought a compromise which would have allowed ships which were more than half-Scottish in ownership to be free ships, or British as it were. This tract treated an interesting aspect of Scottish commerce.

274 Observations on the tryal of Capt. Green, and the speech at his death. London. 1705. $1 / 2^{\circ}$; both sides. (John Menzies.) L, E, O, MH

[idem] Observations made in England, on the trial of Captain Green, and the speech at his death. London printed, and Edinburgh re-printed, by J. W. 1705. $4^{\circ} ; 1-8$ pp. L, E, O

The trial and execution in Scotland of Captain Thomas Green, the Englishman accused and found guilty of piracy, aroused the anger and indignation of the English who saw the case as a miscarriage of justice. This pamphlet was written by a Scot in London, who sought to dampen the controversy by publishing more of the facts of the case (from the Scots' viewpoint) than had been available previously in England. Because of the emotionalism of the case, his success was doubtful. Sec also No. 54.

275 Observations upon the fourth article of union. [1706]. $4^{\circ} ; 1-8 \mathrm{pp}$.

$\mathrm{E}, \mathrm{CtY}$

In early 1707, many Scottish and foreign merchants realized that it would be possible for a few short months to import goods into Scotland at a low duty and to hold them there until after 1 May, when they could legally carry them into England, which had a higher duty. This legal but somewhat shady process angered the English; the author of this tract attempted to appeal to good common sense and to show that the Scots had simply been smarter than the English-for once-and the English resented it.

276 The occasion of Scotland's decay in trade, with a proper expedient for recovery thereof, and the increase of our wealth. [Edinburgh?]. $1705.4^{\circ}$; 1-2 3-8 pp. (William Paterson; $\mathrm{MH}$, actually plagiarized from Locke.)

L, E, LU-G, CtY, InU, MH

This attempt to analyze Scotland's economic condition was a part of the continuing debate in Anglo-Scottish history which would culminate in one of the primary themes of the union debate. Paterson sought to present an analysis of. Scotland's condition and to show how it might be amended for the better. He did not think much of the schemes proposed by Law for currency reforms and for the introduction of script. Other pamphlets in this series are: Nos. 502 and 122.

277 The occasional letter. Number I. Concerning several particulars in the New Association: The Occasional Bill; a ms. history, \&c. With an examination of some proceedings in the late reign by some passages in the Lord Clarendon's history. With a postscript, relating to Sir Humphrey Mackworth's book, intituled, Peace at home: or his defence of the Occasional Bill. London. 1704 (Arber, Hilary 1703/4). 4 ; 3-4 5-32 pp. (lacking half-title page?). $\mathrm{O}, \mathrm{DFo}, \mathrm{InU}, \mathrm{MH}, \mathrm{KU}$ 
Leslie's attacks upon Scotland and the Scots Presbyterians were such a small part of his overall assault upon the dissenters that they received little direct response. This author refuted Leslie's allegations against them-notably in his Cassandra-and attempted to vindicate William III and the Presbyterians. It was a small part of his overall reply to Leslic.

278 On the union of the two kingdoms, of England and Scotland as represented in one Parliament. London: sold by Benj. Bragge at the Raven in Pater-noster-Row. 1707 (Luttrell, 8 November). $12^{\circ} ; 1-2$ pp.

$\mathrm{MH}$

This was a glorification of the union, of Anne, of the ministry, and of the Parliament; all were to share equally in the victories abroad, which would follow union at home.

279 One nation, and one king. A discourse on Ezek. XXXVII. 22. Occasion'd by the happy union of England and Scotland, which commenc'd on May the 1st. 1707. London: printed by T. Ilive, for Jonathan Robinson, John Lawrence, and John Wyat. 1707 (ca. 5 May). $8^{\circ}$; 1-2 3-24 pp. JoHn Edwarus. L, E, O, DFo, InU

This minister was more interested in the deplorable state of morals in England than he was in the union is such. It was a world-weary sermon filled with admonitions to Englishmen who had strayed from the path of righteousness. Scotland to him was an example of right action in matters of morals; the Presbyterians should be seen as examples of strictness in morals.

280 Overture for an additional clause to the ninteenth article, anent the session in Scotland. [1706?]. $12^{\circ} ; 12 \mathrm{pp}$. $\mathrm{E}$

This proposal for an additional clause in the Articles of Union would have required that judges be selected by the Dean of Faculty and Advocates and Clerks of Scssion from within their numbers. Thus the ability of the English to meddle with Scottish law would have been reduced and one objection to union removed.

281 Overture for limitations on the successors of Her Majesty deceasing without heirs of her body, who shall be likewise Kings of England. [1703] (on or shortly after 22 June). $1 / 2^{\circ}$; one side. (AndREw Fletcher.) E

Fletcher's proposals, presented in this half sheet in most abbreviated form, would have revolutionized government in all aspects. His ideas were far too radical to be given much consideration in 1703, but they were fascinating then and remain so now. The independence and authority of the Parliament would have been unquestioned if they had been adopted. Certainly, monarchy would have had little to do in such a scheme of government.

282 Overture for promoting the trade of this nation: humbly offered to the serious consideration of the ensuing session of Parliament, by a well-wisher to his country. [1703/1705]. $2^{\circ} ; 1-4 \mathrm{pp}$. E, LU-G

This tract really was a statement of Scotland's economic position relative to trade, and only indirectly figured in the Anglo-Scottish debate. However, it was an indication of the 
interest shown in Scotland's trade at that time, and of the role England and others played in it.

283 A paper concerning Daniel Defoe. Edinburgh, printed by James Watson in Craig's Closs. 1708. $4^{\circ}$; $1-8$ pp. (James Clark.) L, CtY

. Edinburgh, printed by James Watson in Craig's Closs. And reprinted with some additions. $1708.4^{\circ} ; 1-8$ pp.

$\mathrm{E}, \mathrm{CtY}, \mathrm{MH}$

Defoe's monumental history (No. 162), although an amazing record of his impressions and participation in the making of the union, could neither please all involved in that controversy nor be an exact record of fact. This particular complaint was a part of the dispute over the actions of the Rev. James Clark, minister of the Tron Church in Glasgow, who viewed the union with decided displeasure and who was held by Defoe to be responsible in part for a riot against the union. Clark declined that honor and questioned the validity of the whole charge. Defoe was accused of living by his pen, which of course he did. The controversy developed as follows: Nos. 162, 283, 311, 28, 182, 336, 17.

284 Parainesis Pacifica; or, a perswasive to the union of Britain. . . . Edinburgh, printed by Mr. Andrew Symson. 1702 ( $\mathrm{L}$ ms. note, 23 October; E ms. note, 26 November). $4^{\circ}$; $i$-ii iii-vi 1-22 pp. Grorge Mackenzie, Earl of Cromartr.) E, LU-G, MH

- (Two ms. letters, addressed "To the Queen," inserted; one of 1 leaf after p. $i i$, one of 4 leaves, after p. vi). L

[variant:] . . By a person of quality. London; re-printed, and sold by John Nutt, near Stationers-Hall. 1702 (HWL, November). $4^{\circ}$; 1-2 3-23 24 blk. pp. $\mathrm{E}, \mathrm{O}, \mathrm{KU}$

The author of this work was firm in his support of a union between England and Scotland, and was eager to convince his fellow Scotsmen that it was advisable in every way. He addressed both England and Scotland, and attempted to demonstrate that the difficulties and losses involved in any union were far less than the disadvantages of remaining separate. The arguments were historical as well as contemporary, and ranged freely over many topics. The author urged an incorporating union which would obliterate all wounds and remove all grievances.

285 The parallel continu'd, between a Presbyterian assembly, and the new model of an English provincial synod. Occasioned by a letter from the borders of Scotland, lately made publick. 1702 (dated 9 December; HWL, December). $4^{\circ} ; 1-8$ pp. (Edmund Gibson.) L, DFo

[title page reset].

The matter of the internal structure within the Church of England, and the strict relationships among the various categories of its members, was an issue in this debate. The Presbyterian Church of Scotland was used as an example of the destruction of Episcopacy and authority within a church, and as an illustration of what the results of a division might be in England. This was an answer to No. 220. 
Passion and prejudice, the support of one another, and both destructive to the happiness of this nation, in church and state; being a reply to the vindicator of Mr. W-r's [Webster's] Lawful prejudices. . . Edinburgh. 1707 (Healey, before 18 March). 4 ; 1-2 3-16 pp. (Daniel Defoe; preface signed D. F.) E

The bitter and unpleasant debate between Webster and Defoc over the loyalty of the Presbyterians in England to the principles of that rcligion continued with this work by Defoe. In it he sought to put the argument into perspective and to express his own shock that Webstcr would engage in such personal combat and would express himself so vehemently against his fellow Presbyterians in England. It was a paper which Defoe apparently sought to suppress out of a desire to halt the dispute and to save face for Webster. The union debate certainly did not lack in personal attacks, but this would seem one of the more unnecessary and illogical of them all. The debate started with Webster's No. 187, to which Defoe replied in Nos. 499 and 109 . Webster countered the latter with No. 40 , and then Defoe produced this tract.

287

The patriot resolved, in a letter to an addresser, from his friend; of the same sentiments with himself; concerning the union. . . . 1707. $4^{\circ} ; 1-2$ 3-32 pp. (Francis Grant.)

L, E, LU-G, InU, MH

The pamphlet debate over the merits of union and its terms attracted many of the best minds of Scotland, but this particular tract ranks among the most competent and most persuasively argued of all those supporting the union. Attributed to Francis Grant, it was a thorough discussion of the most important constitutional, legal, religious, and economic questions then under discussion. It was neither simple nor plainly worded, but it would have appcaled to the more intelligent of those still seeking to understand the union and to decide on the proper course of action.

288 The patriots of Great Britain: a congratulatory poem to those truly noble and illustrious peers who happily united the two kingdoms of England and Scotland, under the auspicious government of Her most Sacred Majesty Queen Anne, \&c. ... London: printed by R. J. [Foxon, Richard Janeway] and sold by J. Morphew, near Stationers-Hall. 1707 (Luttrell, 14 May; published by 17 May). $2^{\circ}$; (i-iv) 1-12 pp. (Attributed by Foxon and others to Joseph Browne; sometimes also attributed to William Oldisworth, both on the basis of its being reprinted in State and Miscellany Poems, 1715.) InU, $\mathrm{MH}, \mathrm{KU}$

The union and 1 May provoked an outburst of congratulatory poetry which tended toward the grandiose, and which usually was more ambitious than successful. This effort, resplendent with classical allusions and historical references, was no more successful than most.

The peril of being zealously affected, but not well: or, reflections on Dr. Sacheverel's sermon, preach'd before the Right Honourable the Lord Mayor, aldermen, and citizens of London, at the Cathedral Church of St. Paul, on the fifth of November, 1709. . . . London, printed for J. Baker at the Black 
Boy in Pater-Noster-Row. 1709 (HWL, November; Kennett, after 22 November; Speck, 28 November). $8^{\circ} ; 12-24$ pp. (George Ridpath.) L, CtY, $\mathrm{DFo}, \mathrm{InU}, \mathrm{MH}, \mathrm{KU}$

$$
8^{\circ} ; 12-2314 \mathrm{pp} \text {. } \mathrm{MH}
$$

This tract is almost totally an "English" affair concerned with political and religious differences in England, and in particular with differences between the high and low Anglicans there. There is a small section in this tract which dealt with the Episcopalians and Presbyterians in Scotland, and the sympathetic attitude among the high tory churchmen in England toward the Episcopalians there. This tract refuted Sacheverell's charges against the Presbyterians, and blunted the plea for assistance to the Episcopalians.

290 A perswasive to the union now on foot, by arguments from nature, reason, and mutual advantage. In two parts. With a method propos'd for the more easy effecting it, and answering the principal objections against it. London: printed and sold by the booksellers of London and Westminster. 1706. $8^{\circ}$ (turned chain lines); (i-ii) $1-545656-1761-80 \mathrm{pp}$. $\mathrm{E}$

The author of this tract supporting the union was neither succinct nor prone to flashy prose. It was a long, tedious, and detailed account of the past relations between England and Scotland, and in particular of the history of previous attempts at union. The tone was one of compromise and reason, but the total impression was one of arid discussion and dull digression.

291 The petition of the Scots East-India and African Company, for reprisal of the ship Worcester, (Tho. Green commander) from East-India, now seized in Scotland, by said company, for reprisal of the ship Annandale, seized in England by the English East-India Company. Unto the Right Honourable, the Judge of the High Court of Admiralty, the petition of Mr. Rodrick Mackenzee, factor for the African Company. London: printed by R. Tooky, in Threadneedle-street; and are to be sold by S. Malthus in London-House. [1705] (January-February). $1 / 2{ }^{\circ} ; 12 \mathrm{pp}$.

The case of Captain Green and his crew was to be one of the most celebrated trials and executions of 1705. This work was among the first to be published in London on the subject; it first gave the petition of Roderick Mackenzie and the Company of Scotland against Green, and then refuted the charges of pirating a Scottish ship which had been brought against Green. Generally, the paper could be said to support Green.

A phenix or the Solemn League and Covenant, of the three kingdoms of Scotland, England and Ireland; for reformation and defence of religion, sworn to in the three kingdoms. With some acts of the church and state, authorizing the same... 1707. $4^{\circ} ; 12-8 \mathrm{pp} . \quad$ L, E, DFo

The Solemn League and Covenant is reprinted here with other documents from the civil war, relating to religion and to Presbyterianism in particular. It was not calculated to reassure Anglicans, who in 1707 were anxious about union with the Presbyterians and who would have viewed the Solemn League and Covenant with extreme suspicion. 
293 A pil for pork-eaters: or, a Scots lancet for an English swelling. . . . Edinburgh [printed by James Watson?]. 1705 (after 11 April). 4 ; 1-2 3-12 pp. (Wriliam Forbes, although sometimes attributed to Alexander Pennecuik.) L, E, CtY, InU, MH

. Edinburgh, printed by James Watson, in Craig's-Closs. 1705. $4^{\circ}$ (A3 as $\mathrm{A} 2$ ); 1-2 3-12 pp. $\mathrm{KU}$

$$
\text { [Edinburgh]. 1705. } 4^{\circ} ; 12-8 \mathrm{pp} . \quad \mathrm{E}, \mathrm{MH}
$$

The Scots did not lack for composers of doggerel against the union, but this piece of invective was unusually severe and unusually well done. Little of an emotional or controversial nature in the recent history of the two kingdoms was ignored or allowed to pass. Darien as well as Captain Green were brought forth and utilized to denote the nature of English intentions. It was a poem calculated to arouse every angry Scot to greater anger. Atwood was a particular target (No. 451).

294 A pindarick ode on the union. . . London: printed for T. C. and sold by J. Morphew, near Stationers-Hall. 1707 (Luttrell, 17 May). $2^{\circ}$; (i-iv) 1-8 pp. Lewis Theobald. L [Foxon, fine paper?], O, CtY, MH

Theobald's contribution to the celebrations on the union expressed the usual sentiments: France would be vanquished through unity, Anne would be glorified, unity would be secured. Neither in sentiment nor in its expression was this effort unique or original.

295 A poem humbly inscrib'd to the Lords Commissioners for the union of the two kingdoms. London: printed; and are to be sold by J. Morphew, near Stationers-Hall. 1707 (Luttrell, 1 May). $2^{\circ}$; ( $\left.i-i i\right)$ 1-8 9-10 blk. pp. (Foxon, MR-C has presentation copy signed Mary Pix, $\mathrm{CSmH}$ copy with dedication signed by John Fowler belongs to another poem.) MR-C, CSmH, KU (lacking pp. 9-10)

This poem in honor of the union was resplendent with cooing doves, maids with garlands, and tributes to the likes of Anne, Marlborough, Godolphin, and others. Such occasions did not always or even usually call forth the best in the poet.

296 A poem on the happy union between England and Scotland. Perfected May the first, 1707. Mirabilis Annus! . . Dublin. 1707. $4^{\circ} ; 1-3$ 4-23 24 pp. C.N. E, O

This poern on the union combined a reproach to those in England and Scotland who opposed union, with the glorification of Anne, Marlborough, and others who had carried England-now Britain-to victory. While it had morc wit and spirit than most such poems, it could not be counted among the great poems of the reign.

A poem to the author of the Scots answer to the Brittish Vision. SEE: No. 332. anent the union, of Great Britain. [Edinburgh. 1707] (E ms. note, February). $1 / 2^{\circ}$; one side. $\mathrm{E}$ 
The Duke of Hamilton was both a popular and an extremely controversial peer in Scotland, and this poem praised him not only as a Scots patriot, but as one of her greatest ornaments.

298 A poem upon the union.... [Edinburgh. 1706] (E ms. note, 19 December). $1 / 2^{\circ}$; one side. $\mathrm{E}$

This short piece of doggerel condemned the union as joining with Scotland's most inveterate enemy.

299. The preface to the Fifth essay, at removing national prejudices, \& considered, in a letter to the author of the Consideration upon trade. [Edinburgh? 1707]. $4^{\circ}$; 1-4 pp. (William Black.) L, E

William Black, feeling that Defoe had mistepresented and maligned him in No. 135, wrote this "preface" to vindicate the comments on malt and salt which he had advanced in his Letter, No. 191. Those views had been ridiculed by Defoe and here were again defended by Black. The issues were the relative prices paid in England and Scotland for beer and ale, and for salt; indeed, the tax on malt and the duty on salt would be issues which would continue to arouse the most vehement protests in Scotland long after the union was concluded. While the entire Black-Defoe controversy is much broader, the direct line of the debate on this tract is as follows: Nos. 408, 85, 191, 135, 299.

Presbyterian persecution examined. SEE: No. 158.

300 The present state of Mr. Greensheilds case, now before the Right Honourable the House of Lords. In a letter from a commoner of NorthBritain, to his friend in Edenburgh. London, printed for John Baker, at the Black-Boy in Pater-noster-row. 1711 (dated 3 February; Kennett, published after 17 February). $8^{\circ}$; 1-2 3-15 16 pp. (George LockharT.) L, E, O, $\mathrm{CtY}, \mathrm{InU}$

[variant:] ...Greenshields ... Edinburgh. np. 1711. $8^{\circ} ; 1-23-1516$ pp. $\mathrm{E}, \mathrm{MH}$

The Greenshields case aroused a furor in England as well as in Scotland, and this tract supposedly sketched the vicws of various factions in England toward the case which was then being considered in the Lords. Despite such attempts, the overall impression was one of support for Greenshields and for a toleration of Episcopacy in Scotland. The author portrayed the Presbyterians as excessively intolerant, and-as a minority religion-lacking popular support and rcligious or legal standing.

301 The present state of the parties in Great Britain: particularly an enquiry into the state of the dissenters in England, and the Presbyterians in Scotland; their religious and politick interest consider'd as it respects their circumstances before and since the late acts against occasional conformity in England; and for tolleration of Common-Prayer in Scotland. . . . London printed, and sold by J. Baker in Pater-Noster-Row. 1712 (ca. 17 May). $8^{\circ}$; (i-viii) 1-352 pp. (Daniel Defoe). L (9 ms. index pp. at end), CtY MH 
Few men were as familiar with Scotland as Defoe, and it therefore was not surprising to find him writing in 1712 against the morc extreme tory, high Anglican views. Defoc recognized the dangers inherent in any attempt to force a religious settlement on Scotland, and sought a more tolerant approach, but it was a forlorn hope. The toleration and patronage bills were near to the hearts of the tories in that Parliament. While this pamphlet was not about the Scots Prcsbyterians it did give considerable time and space to that aspect of the religious settlement.

302 The principles and designs of the high-church party: discover'd in a letter from B. R. Esq; to L. R. Esq; occasion'd by the late address from the county of Bucks. London. 1710 (presented to the Queen, 1 August; published ca. 3 October) $.8^{\circ} ; 1-23-24$ pp. B. $R$. L, E, O, CtY, DFo

Neither in 1708 nor in 1710 did the Scots figure in the elections in England as such. The materials published to influence electors in those elections simply did not consider the Scots or the union enough of an issue to defy the Queen's support for the union. This is one of the few tracts to mention the union as part of an election pamphlet, and it is included to illustrate the use to which the Anglo-Scottish debate was put in England after 1707.

303 The proceedings of the Parliament of Scotland: begun at Edinburgh, 6th May, 1703. With an account of all the material debates which occur'd during that session. To which are subjoyn'd, the several acts past in that session. The Act of Security, as it was voted in the House. The articles of the Claim of Right referr'd to in some of these acts. 1703 [for 1704] (early February). $4^{\circ}$; (i-viii) 1-70 71-86 pp. (George Ridpatr.) O, DFo

-. $4^{\circ} ;(i-i v) 1-7071-90$ pp. E

\section{4. $4^{\circ}$; (i-iv) $1-7071-88$ pp. $\mathrm{KU}$}

Official publications have been excluded from this checklist, and by most counts this set of documents would be included among such works. But it was issued without authority and only purported to be an unofficial account of that Parliament. It can be accepted as a fair account of that meeting as seen by a Scots partisan.

304 Proposals \& reasons for constituting a Council of Trade. Edinburgh. 1701. $8^{\circ}$; (i-xvi) 1-194 197-198 195-196 199200 pp. (William Paterson; formerly erroneously attributed to John Law.) L, E, LU-G, CtY, DFo, InU, $\mathrm{MH}$

This was in part a complicated response to the economic dislocation and distress evident in Scotland in the late seventeenth century. The public outery over the failure of the Darien scheme and the frustration which had been building up in Scotland as the Netherlands and England grew rich through trade, produced great interest in the improvement of trade and industry, and an interest in proposals and projects which either analyzed the reasons for Scotland's poverty or ways to alleviate it. This work surveyed Scotland's economic structure and problems, and proposed ways, including a Council of Trade, to assist in promoting her best interest. 
A protestation and testimony against the incorporating union with England. ... [Sanquhar. 1707] (dated 2 October). $4^{\circ} ; 12-16$ pp. O, InU, $\mathrm{MH}, \mathrm{KU}$

Those Presbyterians who rejected all compromise of a religious nature likewise could not accept a union with a kingdom so sinful and so episcopal as England. This belated protest of the union was a harsh and wrathful one which promised the full retribution of God upon those who defiled and defied Him.

306 The publick spirit of the whigs: set forth in their generous encouragement of the author of The Crisis: with some observations on the seasonableness, candor, erudition and style of that treatise. London : printed for John Morphew, near Stationers-Hall. 1714 (23 February).* $4^{\circ}$; (i-ii) $1-4546$ pp. (Jonathan Swift.) L, E, O, CtY, DFo, InU, MH

- The second edition. London: printed for John Morphew, near Stationers-Hall. 1714. $4^{\circ}$; (i-ii) 1-21 23-45 46 pp. $\mathrm{InU}, \mathrm{KU}$

The third edition. Dublin: printed for J. Henly, bookseller in Castle-street. 1714. $8^{\circ}$; 1-2 3-38 39-40 blk. pp.

$\mathrm{CtY}, \mathrm{MH}$

Steele in his No. 93 wrote one of the most successful and provocative whig pamphlets of the reign, and Swift responded for the tories with this equally famous one. Neither pamphlet had Scotland as a first or even second interest, but Swift responded to several long statements made by Steele on the union, and on Scotland as a part of the new Britain. In his response, Swift unnecessarily reflected so harshly upon the Scots in the Lords that even the tory government officially could not protect him from the outcry. The Scots were offended to the utmost degree and the work was subjected to censure and to censorship. The first three issues appeared in both cancelled and uncancelled states; none of the subsequent issues included the offending passages, but the damage already had been done and could not be repaired.

307 The Queen an empress, and her three kingdoms one empire: or, brief remarks upon the present; and a prospect of the future state of England, Scotland, and Ireland, in a happy union. In a letter to a noble peer. London; printed for A. Baldwin in Warwick-Lane. 1706 (HWL, November). $4^{\circ}$; 1-2 3-32 pp. L, E, O, DFo, InU, KU

[variant:] . . . in a happy union, for the consideration of the Parliament. In a letter to a noble peer. London, printed for A. Baldwin in Warwick-Lane. And M. Gun in Essex-street Dublin. [1706]. $4^{\circ}$; 1-2 3-32 pp. L, O

Writing after the commission to treat of a union had concluded its work, the author took an optimistic view of the advantages to be gained through the union of England and

* These are the only three issues which are extant in an uncancelled state, including the passages regarding the Scottish peers. For a complete biblingraphy and discussion of this pamphlet, see H. Teerink, A Billiography of the Writings of Jonathan Swi/t, edited by Arthur H. Scouten, 1963; and lonathan Swi/t, Political Tracts, 1713-1719, edited by Herbert Davis and Irvin Ehrenpreis, 1964; and John Harris, "Swift's The Publick Spirit of the Whigs: A Partly Censored State of the Scottish Paragraphs," The Papers of the Bibliographical Soriety of America 72 (1978): 92-94 which discusses an intermediate state of the censored issue, containing some modified wording in the Scottish sections. 
Scotland. The pamphlet presented a pleasant prospect for the future while reminding the reader of the perils of the past when three kingdoms had fought among themselves. Ireland's incorporation into the union was envisioned, and all manner of social, religious, economic, and political benefits were discussed.

308 Queries to the Presbyterian noblemen and gentlemen, barons, burgesses, ministers and commoners in Scotland, who are for the scheme of an incorporating union with England, according to the articles agreed upon by the commissioners of both nations. [Edinburgh. 1706] (Defoe, History, ordered burnt by the Parliament of Scotland, 12 December). $4^{\circ} ; 12-4$ pp. L, E, MH

[variant:] Queries to the Presbyterian noblemen, barrons, burgesses, ministers and commoners in Scotland, who are for the schem of an incorporating union with England, according to the articles agreed upon by the commissioners of both nations. [1706]. $4^{\circ} ; 12-4$ pp. DFo

For those Presbyterians who had not given up on the conversion of all of England and Scotland to that religion, the Treaty of Union-with its acceptance of and protection for the Church of England--was seen as too much to bear, and indeed sinful on all counts. This paper stressed that extremely uncompromising position.

309 Queries to the Scots innovators in divine service and particularly, to the liturgical party in the shire of Angus, and places adjacent thereto. Being a compendious collection of the choicest arguments, against the present innovations ... By a lover of the Church of Scotland. 1712. $4^{\circ} ; 1-2$ 3-32 pp. (JoHN Willison.) L, E

This pamphlet dealt almost entirely with an internal Scottish religious matter; but since it spilled over into a discussion of the rclationship of Episcopacy in Scotland to Anglicanism in England, and the relationship of both to Presbyterianism, it has been included. The author, a Scots Presbyterian, accused the Episcopalians of innovative practices in matters of religion, and advanced the proposition that Presbytery was the original structure.

310 The rabbler convicted: or a friendly advice to all turbulent and factious persons, from one of their own number. [Edinburgh. 1706] (E ms. note, 18 December). $4^{\circ} ; 12-4$ pp. (Daniel Defoe.) E, CtY

The attempt to calm those in Scotland who were still opposed to union in the fall and winter of 1706 was no easy task; this effort was only one of many. The author used the "confessional" approach and wrote as though he once had been a foolish young man opposed to union (but had done so out of ignorance and without actual knowledge of the termas). The implication was that those who read them would not oppose them. It was a skillful pamphlet, with a simple but direct approach worthy of its author.

311 Rabbles and authors of rabbles condemned, or some passages of a real letter sent to a gentleman at Edinburgh. [1708]. $12^{\circ}$; both sides. (J.C., i.e., James Clark.) GU 
The first part of this tract supposedly contained passages from a letter written by Clark against tumults, mobs, and rabbles. The second section-a "postscript"-accused Defoe of misjudging Clark and of making unjustified historical statements in his History. The sequence of the controversy was: Nos. 162, 283, 311, 28, 182, 336, 17.

312 Reasons against passing the bill to prevent carrying forreign goods from Scotland to England, after the union, contained in a second letter from a Scots factor at London, to a merchant in Edinburgh. [Edinburgh? 1707] (dated 22 April). $1 / 2^{\circ}$; one side. L

On 1 May, England and Scotland became one trade unit; but between January and May, goods still might be imported into Scotland from abroad at a cheaper rate than into England, and then, after 1 May, shippped south and sold for a considerable profit. The attempt to prevent this prompted much activity in England and much opposition in Scotland. This tract sought to explain why the English, in and out of the Parliament, would be unable to prevent this traffic.

313 Reasons for a toleration to the Episcopal clergie, and objections against it answer'd. ... Edinburgh. 1703. $8^{\circ} ; 1-23-2728$ pp. (Robert Calder.) L, E

Early in her reign, Anne had indicated that she would not encourage the prosecution of Episcopalians in Scotland. Calder sought to sample the mood of the Presbyterians toward a toleration through this tract, which immediately aroused a hostile reaction among them. While not without its barbs, this pamphlet is not among the most combative of Calder's works. It is indicative of the times that his arguments, which do not seem unreasonable now, should have caused great consternation in 1703 .

314 Reasons for an union between the kingdoms of England and Scotland. The first in a speech in Parliament. The other delivered to his Majesty King James the First, in private, by the late famous Francis Lord Bacon, Viscount of St. Albans. With another speech by the same noble peer, concerning the article of general naturalization of the Scotish nation. To which is added, The present state of the case between England and Scotland. With an introduction to the whole.... London, printed: and sold by Benj. Bragge, in AvemaryLane. 1706 (HWL, February). $4^{\circ}$; (I-VIII) i-vii viii blk. $1-2930$ blk. $31-39$ $40 \mathrm{pp} . \quad \mathrm{InU}$

This work is included not because of the Bacon reprints, but for the contemporary commentary at their conclusion. The author, an Englishman, wrote in late 1705, when union was being widely discussed, but when the terms of the agreement still were ill-defined. He stressed the danger of France's possible assistance to Scotland if a union were not concluded. He cited the advantages-Scotland's excess population, internal and external security; and the disadvantages-religious, legal, and national differences. He was for the union, all things considered, but he did not correctly estimate the extent of differences or difficulties involved. 
England; in a letter to a Scots Member of Parliament, from one of his electors. $\ldots$ [1713] (dated June). $8^{\circ} ; 1-23-3839-40$ blk. pp. P.S. E, O

This tract-in favor of dissolving the union-was a long recitation of Scottish grievances which had accumulated before the union and after. The list was a long one, and included constitutional, economic, political, and other related charges: bribery was alleged to have been used to secure the treaty; trade had been lost in Scotland; unjust taxes had been applied there in violation of the treaty; the Church of Scotland was endangered; and the succession to the throne had been made uncertain. These and many more gricvances were all part of this argument for the dissolution of the union.

316 Reasons humbly offered to the Honourable House of Commons. Why the eldest sons of the noblemen of Scotland have a right to be elected Members of that House. [London? 1708?]. $2^{\circ}$; 1-3 4 pp. L, E

One of the first problems before the newly elected House of Commons in 1708 was the question of the right of the cldest son of a Scottish nobleman to be elected to the House of Commons from a Scottish borough or shire. This tract argued that such sons were qualified both by the terms of the Treaty of Union, which did not cxclude them, and by the ancient election laws of Scotland, upheld by the union, which allowed their election. The argument did not prevail and they were excluded.

317 Reasons humbly offer'd to the Right Honourable the Lords Spiritual and Temporal assembled in Parliament, against passing the bill for laying duties upon goods which may be brought by Her Majesty's subjects from Scotland to England after the commencement of the union. [1707] (April?). $12^{\circ}$; one side.

$\mathrm{E}$

In April the English merchants demanded that Parliament act against the Scottish and foreign merchants who had imported goods into Scotland at a lower duty for resale in England-which had a higher duty--after 1 May 1707. This tract was a response to the English merchants and to the proposed bill. It pointed out that the bill as it was presented was a gross violation of the Treaty of Union, and that it was a punitive measure at best, with dubious consequences for all concerned.

318 Reasons in defence of the standing laws about the right of presentation in patronages: to be offered against an act (in case it be) presented for alteration thereof: by a Member of Parliament; in a letter to his friend in the country. Edinburgh. 1703. $4^{\circ} ; 1-23-1516$ blk. pp. (Francis Grant.) $\mathrm{E}, \mathrm{O}, \mathrm{DFo}, \mathrm{KU}$

The restoration of patronage was a matter much debated in the reign of Anne, and one which appealed greatly to the more conservative members of the Church of England who wished to see it restored in Scotland. This author sought to block such action by reciting many reasons why it should not be considered.

319 Reasons why the East-India Company ought to pay the equivolent agreed to be paid the Scots Company by the Articles of Union: and also some 
cautions offer'd with respect to the renewal of their grant. [1708] (ca. March). $2^{\circ} ; 12-34$ pp. $\quad \mathrm{MH}$

This tract, which had a decidedly Scottish approach, attacked the East India Company, which the author believed to be a closed organization operating solely in its own selfinterest. That company was termed monopolistic and arrogant; and the scizure of a ship (the Annandale), without due cause and in violation of the company's charter, was cited as an example of its misconduct. The author called for a revicw and revision of the charter of the company and sought to make it more accountable to justice.

Recommendation of a charitable contribution: for the promoting religion and the knowledge of God in the Highlands: with an account of the resolutions of the Synod of Glasgow for that end, and of the desolate state of those parts. [1702/1703?]. $1 / 2^{\circ}$; one side.

$\mathrm{E}$

The Synod of Glasgow and Air appealed to the clergymen and laymen within the synod to assist in efforts to propagate Christian knowledge in the Highlands, to erect schools and libraries there for the common good of the people, and to combat Popery and superstition. It might be regarded not only as an attack upon Catholicism, but also as a part of the general movement in this period to extend Christian knowledge to anyone without it, whether in the Highlands, Ireland, or the Americas. See also Nos. 89 and 252. province, considered. With an historical account of the grievances the Scots complain they have suffer'd in their religion, liberty, and trade, since the union of the crowns; which they assign as the cause of their delay to come into the same succession with England, until they have a previous security against such grievances for time to come... L London, printed: and sold by Benj. Bragge in Ave-Mary-Lane. 1705 (before 6 June). $4^{\circ}$; 1-2 3-48 pp. (George Ridpatr.) $\mathrm{CtY}, \mathrm{DF}$ o

[variant:] . . to England, as a province . . London, printed: and sold by Benj. Bragg in Ave-Mary-Lane. [1705]. 4 ; (i-ii) $1-7170$ pp. L, E, O, InU, $\mathrm{MH}$

[variant:] ...grievances for time to time. London, printed: and sold by Benj. Bragg in Ave-Mary-Lane: and re-printed at Edinburgh. 1705 (before 26 June, when it was discussed in the Privy Council). $4^{\circ} ; 1-23-36$ pp. E, O, LU.G, $\mathrm{KU}$

Having rejected the possibility that difficulties between England and Scotland would lead to warfare, Ridpath asserted that to the contrary, both sides had backed down sufficiently to engage in the first stages of a negotiation for a treaty. Before negotiations could be completed however, Scotland's grievances had to be understood and the author proceeded to discuss them from three approaches-religion, liberty, and trade. He concluded with an admonition to those who would advance conquest as an alternative to treating with Scotland, and reminded them of Scotland's potential either in alliance with or against England. It was a provocative work, not likely to win friends among the more militant English. This was answered in Nos. 327 and 348. 
322 Reflections on a late speech by the Lord Haversham, in so far as it relates to the affairs of Scotland. Containing, a brief account of the late change in the Scots ministry. Of the miscarrying of the Hanover succession in the Parliament of Scotland. And of the acts of that Parliament for arming their people, and exporting wool, \& $\mathrm{c}$. In a letter to a friend. London: printed, and sold by B. Bragg, at the Blue-Ball in Ave-Mary-Lane. 1704 (HWL, November). $4^{\circ}$; 1-2 3-32 pp. (Perhaps by George Ridpath; formerly erroneously attributed to Daniel Defoe.) L, O, CtY, DFo, InU, MH, KU

[variant:] ... In a letter to a friend. To which is prefixt the speech itself. Edinburgh, re-printed by J. W. and sold by Mr. Robert Freebairn, at his shop in the Parliament-Closs. 1704. $4^{\circ}$; 1-2 3-6 7 blk. 8-26 pp. LU-G

Although other rebuttals had been concerned with Scotland only incidentally, this pamphlet was devoted in its entirety to a defense of Scotland and the ministry from charges made by Haversham in his speech of 23 November (No. 243). The author was, or purported to be, a Scot. In content and intention the tract seeks to vindicate and to explain what happened in Edinburgh with the $\Lambda$ ct of Security, why, and what it meant in terms of the succession. The obvious intent was to calm the English, and to defuse the issue raised by Haversham, who was not the first to make the charges, but who enjoyed a certain bombastic success in spreading them. Cf. Nos. 243, 155, 326.

Reflections upon the present posture of affairs: with relation to the Treaty of Peace, now on foot. In a letter to a friend. London: printed for J. Churchill, at the Black-Swan in Pater-Noster-Row. 1712 (dated 11 February 1711). $8^{\circ} ; 1-23-44$ pp. M.N.

L, E, CtY

Although it was not a pamphlet aimed at Scotland as such, this work included an interesting and detailed account of the Greenshiclds case from the point of view of an English high churchman. The author took care to note that the decision by the Lords to concern themselves with it as a civil case involving the actions of the nagistrates of Edinburgh and the Lords of the Session, prevented a precedent for the involvement of that court in matters ecclesiastical, whether relating to the Church of Scotland or (more to the point) to the Church of England. The Lords' decision was quite welcome to the author on that as well as on religious grounds, however.

324 Remarks for the salt-masters, fishers of salmond, herrings and whitefish, and others who make use of Scots salt, humbly offered upon the eighth article of the Treaty of Union. [1707]. $12^{\circ}$; both sides. L, E

The eighth article of the Treaty of Union provided more difficulty than most of that documents' provisions. In this case the problem was the origins of and use of salt by fishermen in Scotland. The provision being contested was one requiring the use of foreign salt. This was held to impose a hardship on fishermen accustomed to using domestic salt, and on those who cured particular types of fish which required domestic salt. The entire issue of salt in fishing was one which would continue for years after the treaty had been ratified. 
Mr. Greenshields, \&c. The notorious falshoods contained in it, laid open; and the proceedings against him in Scotland, vindicated. With the answers of the Magistrates of Edinburgh, to his Bill of Suspension, \&c. And a list of the Episcopal ministers, who enjoy churches and benefices in Scotland, without being oblig'd to conformity. London, printed for B. Bragge, at the Raven in Pater noster Row. 1710 (ca. $25 \mathrm{March}$ ). 4 ; 1-2 3-36 pp. L, O, CtY, KU

This Presbyterian position paper was published to counter Episcopalian publications in behalf of Mr. Greenshields, the Episcopal minister arrested and imprisoned in Edinburgh in 1709. At stake were such issues as the validity of the ordination of Greenshields; the rights and duties of the ecclesiastical and secular authorities in relationship to each other; toleration for Episcopalians; harassment if not legal persecution for those Episcopalians who used the Book of Common Prayer; and the right of appeal to the new British Parliament. This paper defended the Presbyterian magistrates in their actions against Greenshields, and exposed the Episcopalians as untrustworthy. This, like No. 152, was an answer to No. 498.

326 Remarks on the Lord Haversham's speech: which he made in the House of Peers, on Thursday, Novemb. 23. 1704. [1704]. $4^{\circ}$; 1-4 pp. L, O

Haversham's charges, which he made in his speech of 23 November (No. 243), were certain to arouse a rebuttal; this work was a successful attempt to refute his charges with as much wit as weight. The author defended Marlborough, Rooke, and the Queen, and then quickly skirted the Scottish question. The Scots enjoyed few partisans in England, and the whigs had no desire to be saddled with them as a matter of policy. The author simply accused Haversham of having a hot head, and suggested that cool words would advance a union more quickly than hot ones. Cf. Nos. 155, 243, 322.

327 Remarks upon a late dangerous pamphlet, intitled, The reducing of Scotland by arms, and annexing it to England as a province, consider'd, with an historical account of the grievances the Scots complain they have suffer'd in their religion, liberty and trade since the union of the crowns, \&c. For which pamphlet the author and publisher are bound over to appear at the Queen's Bench Bar next term. London. 1705. $4^{\circ}$; 1-8 pp. L, LU-G

The arguments advanced by Ridpath in No. 321 were too provocative to pass unnoticed, and this author violently disagreed with Ridpath's interpretation of Scotland's history and present condition. The counter-attack was one which stressed England's innocence and good will as opposed to Scotland's self-interest and bad judgment. Scotland was termed a client state, its justice in the case of Captain Green was said to be defective, its religious structure was thought incompatible with monarchy, and its problems with Darien of its own making. This pamphlet was not calculated to encourage moderate feelings in England or Scotland. This was an answer to No. 321, as was No. 348.

Remarks upon a pamphlet intitul'd, The considerations in relation to trade. SEE: No. 533.

Remarks upon the Lord Havarsham's speech in the House of Peers, 
Feb. 15. 1707. [Edinburgh. 1707]. $4^{\circ} ; 1-8$ pp. (Daniel Defoe.) E, LU-G, DFo

This answer to Lord Haversham was written as though by a Scotsman who therefore could refute criticisms which Haversham asserted Scotland felt against the union. The author declared against a federal union so much advanced by Haversham and denied that two churches were incompatible in one kingdom. Haversham, however, was so confused on many points that Defoe did not have to work too hard to show up inconsistencies in his speech. In conclusion he suggested that perhaps Haversham was nothing more than a disappointed courtier out of office. The speech (No. 242) also was answered in Nos. 256 and 34.

329 Remarks upon the representation made by the Kirk of Scotland, concerning patronages. [1712?] (before 22 May 1712). $2^{\circ}$; 1-4 pp. (James Gray.) $\mathrm{E}$

The toleration and patronage bills both appeared to the Presbyterians of Scotland as gross violations of the Articles of Union and as concerted attacks upon the Church of Scotland. They petitioned and wrote against those bills, but in turn they were answered by such works as this paper, which attempted to refute arguments against the bills and to present justification for their passage. This was written in answer to an unpublished document by Thomas Blackwell, entitled "Representation against the bill for restoring patronage in 1712."

330 Remarks upon the tryal of Capt. Thomas Green and his crew: lately printed in Scotland and re-printed here in London; wherein the proceedings of their High Court of Admiralty are consider'd, their arguments to convict the pretended criminals refuted; and the said captain and his crew are fully clear'd and purg'd from all aspersions of piracy, robbery and murder, for which he and others have been, under a form of justice murder'd, and the rest remain in prison under the sentence of death, tho' not yet put in execution. London. 1705 (HWL, June). $2^{\circ}$; 1-2 3-16 pp. L, DFo, InU

The case of Captain Green of the Worcester, executed in Scotland for piracy, did not cool down when the documents were published to show Englishmen that the trial had been a fair one; rather, as indicated in this work, the furor continued. This tract sought to prove that Green was innocent, and it contained his final words proclaiming his innocence.

331 A reply to the authors of the Advantages of Scotland by an incorporate union; and of the Fifth essay, at removing national prejudices. Or, a vindication of the author of the Advantages of the Act of Security, in opposition to the incorporating union. [Edinburgh]. 1707 (dated January). $4^{\circ}$; 1-2 3-32 pp. (WILliam BLACK, although formerly attributed to Dugald Campbell.) L, E, LU-G, CtY, MH

This rebuttal to Defoe's Fifth Essay (No. 135) and to the author of The Advantages of Scotland (No. 15) sought to counter arguments by the two authors to defend the union and to gain support for the articles. This author defended his own statements against the union, and attempted to prove that union would destroy Scotland's political, religious, 
economic, and social structure. The argument had deteriorated to a charge-countercharge in which the real problems were obscured. This tract actually answered three works: No. 103 (which was written in answer to No. 192); No. 15 (which had answered No. 16); and No. 135, which was part of the larger Black-Defoe debate, the sequence of which is as follows: Nos. 408 and 412, answered by Nos. 138 and 85, both of which were answered by No. 191. Defoe responded to this with No. 135, and Black answered this with Nos. 299 and 331.

332 A reply to the Scots answer, to the British Vision. [Edinburgh. 1706] (after 28 November). $1 / 2^{\circ}$; one side. (Daniel Defoe.) L, E, MH [variant:] ... answer to the.... $\mathrm{E}$

[idem] A poem to the author of the Scots answer to the Brittish Vision. ... [Edinburgh. 1706]. $12^{\circ}$; one side. (This was claimed by Peter Murray Hill as a previously unidentified first edition. It was more than likely printed from another ms. copy of the poem. For full details, see Foxon, No. D-150.) $\mathrm{MH}$

Defoe loved nothing more than to mock such men as Belhaven; indeed, on this occasion that nobleman did offer great opportunities for mockery. This "poem" sought to ridicule through false praise, and did so admirably. The sequence of the debate was: No. 241, which was answered by Nos. 398 and 88, as well as by No. 30, which was followed by Nos. 525, 355, 332, 374, 118.

333 Report of the committee concerning the Indian and African Company. Edinburgh 21. February, 1707. [Edinburgh. 1707]. 1/2 ${ }^{\circ}$; both sides. $\mathrm{E}, \mathrm{O}$

This official document is included to provide information as to the amount of the equivalent estimated to be owed to the Company of Scotland, and the manner in which those moneys were to be distributed. The report of the committee also addressed itself to some of the problems raised in No. 465 .

334 Reports and extracts out of the register books of the African and Indian Company of Scotland, relating to Mr. Paterson's claim on the said Company. To the Right Honourable the Earl of Seafield Lord Chief Baron, and the other Barons of Her Majesty's Court of Exchequer in North-Britain. The report of Mr. Roderick Mackenzie, late secretary to the Indian and African Company. [London? 1708]. $2^{\circ} ; 1-10$ pp.

E

After 1700, Mr. Paterson sought compensation for losses which he had suffered in the failure of the Company of Scotland; throughout the reign of Anne he petitioned for redress of his losses. Such of his petitions which are purely personal have been excluded, while those reports which bear upon the Company of Scotland generally had been retained.

335 A representation of the Scotch peers, 1711/12. On Duke Hamilton's case. [London? 1712]. $2^{\circ} ; 1-4$ PP. L, DFo 
The refusal of the British House of Lords to seat the Scottish Duke of Hamilton in his new capacity as the Duke of Brandon in the British peerage raised the question of the exclusion of the Scottish peerage, and them alone, from the full enjoyment of a British peerage. The followers and supporters of Hamilton among the Scottish peerage, as well as those concerned with this violation of the spirit of the union, protested to the Queen and sought redress. The rebuff offered to Hamilton could not fail to exacerbate Scottish attitudes toward England.

336 A reproof to Mr. Clark, and a brief vindication of Mr. De Foe. Edinburgh, printed and sold by John Moncur at the foot of the Bull-Closs foragainst the Trone. 1710 (Moore, before November). $4^{\circ} ; 1-8$ pp. (Daniel Defoe.)

\section{L, E, CtY}

The Clark-Defoe controversy revolved around words spoken before the Act of Union in a most emotional situation and around Defoe's recounting of those events and words in his No. 162. In this paper Defoe defended his honor against attacks by Clark; he stated that the offending passages had been modified, but that the printer and binder had not understood and therefore had bound the old pages. Also, he said that he had never promised to do more than correct matters of interpretation, and not matters of fact; and that Clark was guilty of the most abusive language against him. The entire matter had become most complicated and most unpleasant. The debate was: Nos. 162, 283, 311, 28, $182,336,17$.

337 The retoration of Episcopacy in Scotland, the only sure foundation for a lasting union with England in a letter to Sir J. P. Bar. SEE: No. 233A.

338 The Review review'd. In a letter to the Prophet Daniel in Scotland. [1707] (April). $4^{\circ}$; (i-ii blk.) $12-4$ pp. $\mathrm{CtY}$

This extremely personal attack upon Daniel Defoe, and especially upon Defoe in Scotland, sought to expose him as a social climber and as a man without social or economic support for the position which he claimed. Since Defoe was then in Scotland and had been there for some time, the assault included details of his activities in Edinburgh which could be known only to someone familiar with his life and routine there. Opposition to the union was combined with antagonism to Defoe's role in promoting it.

The right of succession, to the crown and sovereignity of Scotland, argued. I. A description of Scotland. II. The original and progress of the kingdom there. III. Present state of the same. IV. Several competitors to the succession. Of the serene House of Hanover. V. The interest of the kingdom, with respect to the competitors, consider'd. VI. The interest of England, as concerning that succession. With a proposition, how to determine it, without arms or expence. London. $1705.4^{\circ}$; (i-ii) $1-2122$ blk. 27-60 pp. (L note, pp. 23-26 probably cancelled at time of printing).

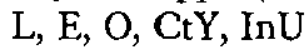

The problem of the succession to the throne of Scotland was a major issue in 1705, and this author attempted to deal with it--first by explaining to an English audience something of the laws, geography, and customs of Scotland, and then by considering the signifcance of the Scottish succession to England. The author, while not hostile toward 
Scotland, obviously felt that a closer union with a common succession was preferable to an independent Scotland and England.

340 The rights and interests of the two British monarchies, inquir'd into, and clear'd; with a special respect to an united or separate state. Treatise I. Shewing the different nature of an incorporating and federal union; the reasons why all designs of union have hitherto prov'd unsuccessful; and the inconconsistency (l) of an union by incorporation with the rights, liberties, national interests, and publick good of both kingdoms. ... London. 1703. $4^{\circ} ;(i$-viii) 1-68 pp. (James Hodges.) L, E, LU-G, CtY, DFo, InU, MH, KU

[variant:] . . inconsistency. . . . Edinburgh, re-printed by John Reid for James Donaldson, and are to be sold at the Caledonia Coffee-House. 1703. $8^{\circ}$; (i-x) 1-42 45-72 81-88 pp. L, E (both copies lacking sig. K)

This extremely successful anti-union pamphlet provoked Defoe to respond in numerous issues of the Review. Hodges denied the advantages of an incorporating union, and argued: that the united Parliament would be dominated by England; that the established Church of Scotland and that of England were incompatible; that England would not abide by the treaty; and that eventually all would be losers, England no less than Scotland. In conclusion he argued that England was far too sinful for a union to be successful.

341. . The rights and interests of the two British monarchies, with a special respect to an united or separate state. Treatise III. Containing farther inquiries into the best means of procuring a happy union betwixt the two kingdoms; with a special regard to the argument, that the making both nations one people, must also make them of one interest. ... London. 1706 (before 2 November). $4^{\circ}$; (i-ii) 1-86 75-90 103-139 140, errata 141-142 blk. pp. (James Hodges.) E, O, LU-G, CtY, DFo

This extended argument against union worked through 31 interests of Scotland which would be lost or abridged if an incorporating union were completed. Hodges' primary theme was that the union as proposed would not allow for individual considerations, but would obscure and eliminate separate items. Hence, Scotland's church, Parliament, law, liberties, taxes, trade, fishing, and other particular concerns would be lost within the larger unit and would have no real reason to consider them. If Scotland were more united and more independent, then she might later treat with England on equal terms. Apparently, Treatise II was never published. This answered No. 174, and was in turn answered by Nos. 225 and 138. See also Nos. 456 and 133.

342 The rights and liberties of the Commons of Great Britain, asserted and explained. In a letter from Scotland to a Member of the House of Commons. [London] printed for J. Morphew near Stationers Hall. [1708] (January-February). $4^{\circ} ; 1-8 \mathrm{pp}$. $\mathrm{E}$

This political pamphlet was a response to the attempt in early 1708 to abolish the Scottish Privy Council and the system of local government in Scotland, and to bring it more closely in line with the English system of justices of the peace. This writer sought to expose the Scottish system of hereditary jurisdictions and supcriorities, and to show how far short it 
fell of the English system. The emphasis was upon an explanation of the system and how it operated, and for that reason it is a valuable introduction to Scottish local government in $1707-1708$.

343 The rise and progress of the charitable collections of England, towards the relieff of the distressed Episcopall clergy of Scotland. [1713] (dated 18 September). $1 / 2^{\circ} ; 12 \mathrm{pp}$.

E

This highly emotional account of the plight of the Episcopal clergy sought to arouse among the Anglicans pity and financial support for their religious colleagues to the north. The history of the Episcopalians in Scotland and the continuing financial troubles which plagued them in exile from their ministries comprised most of the tract.

A scheme for uniting the two kingdoms of England and Scotland. See: No. 129.

A scheme of Scotland's product and manufacturies. SEE: No. 4.

344 A scheme of union between England and Scotland, with advantages to both kingdoms. London: printed by E. P. for R. Wilkin, at the King's Head in St. Paul's Church-Yard. 1705. 12 ; 1-2 3-23 24 pp. Peter Paxton. L, O, LU-G, DFo, InU

1705 (before 18 May). $8^{\circ}$; 1-2 3-23 24 pp. E, LU-G, MH

Of the many types of union proposed in 1705 and 1706, this one by Paxton was among the more unusual. He opposed a union of trade or of defense, but not one of politics, religion, or law, all of which were to remain separatc. In matters of trade, however, the two nations would have a common interest and a common market, with the colonial sphere opened to Scotland. As an alternative to an incorporating union, it was an interesting idea, but it did not receive serious consideration because trade was not the sole or even the most important reason for a union.

345 A scheme proposing a true touch-stone for the due trial of a proper union betwixt Scotland \& England; especially, as to its fitness for Scotland ... By the author of the Character of the true publick spirit. . . Edinburgh. Printed by Mr. A. Symson. 1706. $8^{\circ}$; (i-xviii) 1-34 pp. (ANDrew Brown.) $\mathrm{E}, \mathrm{MH}$

This scheme, supposedly written before the publication of the articles of the Treaty of Union, sought to provide a framework within which the terms of the union might be judged and accepted or rejected on Scotland's part. The questions raised were abstract, but nonetheless directed at aspects of Scottish political, religious, and economic existence, which would have to be protected or advanced before a union could be accepted. This was reprinted in No. 457. See also: Nos. 123 and 376.

346 Scotch-cloath, or occasional-conformity. London. 1711 (Luttrell, 11 July). $1 / 2^{\circ}$; one side. (Anonymous, although at times attributed to Jonathan Swift.) L, MH 
Despite the title, this poem has little to do with Scotland as such, and nothing to do with the Presbyterians in Scotland. Rather it was a diatribe, although a witty one, against those dissenters in England who conformed to the Church of England on certain occasions in order to qualify for civil or military positions.

347 The Scotch echo to the English legion: or, the union in danger, from the principles of some old and modern whigs in both nations, about the power of Parliaments. Being every word collected from their own writings, and here publish'd for the consideration of those who are capable of forming a test to secure the union from the dangerous consequences of such principles. Edinburgh. 1707 (ca. 11 February). $4^{\circ}$; (i-iv) 1-20 20-21 pp. L, E, InU, MH [idem] The Scots echo to the English legion: or, the Scots protesters within doors, and addressers without. Copying after the modern English whigs in their Legion, Jura Populi Anglicani, \&c. With the opinion of the old Whigs in both kingdoms, concerning Parliaments and others who surrender the peoples liberties without their consent, and against their instructions. ... [1707]. $4^{\circ}$; (i-iii iv blk.) $12-20 \mathrm{pp.} \quad \mathrm{MH}$

The question of the authority of the monarch and Parliament to alter the fundamental constitution was one which interested many of those who opposed the union in 1706/1707. This author excerpted materials from five whig tracts on constitutional affairs in the second half of the seventeenth century, and argued from them that the populace had the right to seize authority when betrayed by the King and Parliament.

348 The Scotch patriot unmask'd, in animadversions upon a seditious pamphlet, intituled, The reducing Scotland by arms, and annexing it to England as a province, considered.... London: printed, and are to be sold by J. Nutt, near Stationers-Hall. 1705 (Arber, Michaelmas; HWL, December). $4^{\circ}$; 1-2 3-60 pp. William Atwood. L, E, O, DFo

Atwood, in this rather savage blast at Ridpath, sought to counter the pro-Scottish ideas which the latter had advanced in his newspapers and pamphlets. Atwood and Ridpath differed, line by line, pamphlet by pamphlet, on interpretations of almost every problem or event in Scotland's past or present. Ridpath supported the claim that Scotland was a sovereign kingdom, able to settle her own fate on her own terms. Atwood saw this as historically false, possibly pro-French, and certainly anti-English. While Atwood was not anti-Scottish, he did deny the cardinal point that Scotland was potentially mistress of her own future. The direct sequence of the debate was: Nos. 321, 327, 348. This work also refers to almost all of Ridpath's previously published works, e.g., Nos. 10, 58, 108, 157, 247.

349 Scotland characteriz'd: in a letter written to a young gentleman, to dissuade him from an intended journey thither. [London? 1701] (O ms. note, $28 \mathrm{March}$ ). $2^{\circ}$; 1-4 pp. E.B. ("The author of the Trip to North-Wales"; possibly Edward Bysshe, possibly Edward Ward).

$\mathrm{O}, \mathrm{CtY}$

[idem] A description of Scotland, and its inhabitants. London: printed and sold by most booksellers in London and Westminster. $1705.4^{\circ} ; 1-8 \mathrm{pp} . \quad \mathrm{L}$ 
Early in the reign of Anne, Scotland was not popular in England, and this tract traded upon that dislike for most things Scottish. The author, who was counseling a student seeking to go north to school, spared few if any of the traditional cliches about the Scots. The Scot was described as a boor, lacking all graces; if educated, he had lived abroad. The description of Scots women was most scurrilous, and their cooking was held to be beyond consumption. Of greater interest is the account of education at the universitics, but they also were held to be inferior to the English. It was not a work to please the Scot. Scotland has been in, is now in, or may be in since the union; with some humble proposals for the remedy. Edinburgh, printed by the heirs and successors of Andrew Anderson, printer to the Queen's most Excellent Majesty. [1708] (late April/early May). $4^{\circ}$; $1-8$ pp. (Daniel Defoe.) E, LU-G, $\mathrm{MH}$

Written after Defoe had arrived in Edinburgh in mid-April and before the elections in May, 1708, this was a piece of election propaganda which sought to rally the Scots in support of the union and the government, and to remind them of the folly of political fragmentation and disunity against the French. The author urged unity not only for political purposes but also as an end in itself, and as the only way in which the advantages opened by the union might be realized. Unity, with loyalty to the Queen and ministry, was the way to peace and prosperity. Cf. No. 254.

351 Scotland's great advantages by an union with England: showen in a letter from the country, to a Member of Parliament. $1706.4^{\circ} ; 1-23-12 \mathrm{pp}$. (William Seton.) L, E, LU-G, InU, MH

The Scot who wrote this tract was certainly for the union: indeed, it was one of the most persuasive of the pamphlets which appeared in Scotland in favor of the treaty. The author attempted to calm religious fears and to stress the peace and accord which would follow union, and the defent of foreign enemies abroad who made use of discord. Trade and commerce would thrive, and although the nobility might feel slighted, their individual interests were less important than those of society at large. He also felt that while Scotland was weaker than England, she was not without some things to contribute. Union with plenty and peace was preferable to disunity with slavery and poverty.

352 Scotland's interest: or, the great benefit and necessity of a communication of trade with England. Being a brief account of the chief motives that ought to engage us to insist on it, at this juncture: and of the danger of neglecting so to do. Humbly offered to the consideration of the High Court of. Parliament.... 1704. $4^{\circ}$; 1-2 3-8 pp. (Formerly attributed to Andrew Fletcher, although probably not by him). E, LU-G, CtY, DFo, MH

In 1704 and 1705, Scotland not only felt increasing pressure from England to settle such matters as the succession, but also an increasing optimism that Scotland might be able to force England to make concessions in a union. This author, believing that trade access to England's markets was essential, wanted Scotland to move slowly and with careful attention to her best interests. He feared that Scotland would lose her advantage by promising too much to an England which would give her nothing in return. 
353 Scotland's speech to her sons. [Edinburgh? 1706?]. $12^{\circ}$; one side. (James Clark.) L, E, DFo, MH

This highly emotional appeal in the name of Scotland against the union was sure to activate the more patriotic Scotsman who agreed that his country was being sold for an equivalent, and that Scotland's ancient rights and liberties were being bartered by men who did not deserve to be called Scotsmen.

354 [Scot]lands tears, or Scotland bemoaning the loss of her antient priviledges upon consideration that the House [of] Commons have past the bill discharging all [foreign liquors] \&c. to be exported into England aft[er] the first of May. [Edinburgh? 1706/1707]. 1/2 ${ }^{\circ}$; one side. L (copy torn)

This elegy upon the death of Scotland employed every possible emotional issuc to draw from the reader a tear, or a flood of them, for the loss of Scotland's independence and sovereignty. Where were the brave Scots of old who would rather have died than surrender Scotland's rights and liberties? It was melodrama of the first order.

355 A Scots answer to a British Vision. [Edinburgh. 1706] (POAS, 2728 November). $1 / 2^{\circ}$; one side. (John Hamilton.) E, MH

This reply to Daniel Defoe's The Vision (No. 525) ridiculed the poet and his poem; it was doggerel at its best (or worst), with some attempt at humor and political puns. The sequence of the debate was: No. 241, which was answered by Nos. 88 and 398, as well as by No. 30, which was answered by No. 525. It was followed by Nos. 355, 332, 374, 118.

The Scots echo to the English legion. SEE: No. 347.

356 The Scot's narrative examin'd; or, the case of the Episcopal ministers in Scotland stated, and the late treatment of them in the city of Edinburgh enquir'd into: with a brief examination, into the reasonableness of the grievous complaint of persecution in Scotland, and a defence of the magistrates of Edinburgh, in their proceedings there: being some remarks on a late pamphlet, entitled, A narrative of the late treatment of the Episcopal ministers within the City of Edinburgh, \&c. London. 1709 (Lee; Moore, 19 February; HWL, February). $4^{\circ}$; (i-iii) iv-viii $i x-x 1-4142$ pp. (Daniel Defoe.) L, E, O, $\mathrm{CtY}, \mathrm{DFo}$, InU

If the Episcopalians had had their say in No. 261, the Presbytcrians represented by this author now responded from an opposing point of view. The Episcopalians in Scotland were equated with Jacobites who prayed neither for Anne nor for the realm, who worked against the union, who sought to subvert the succession, and who wanted to disestablish the Church of Scotland. They deserved neither sympathy nor encouragenent. The Presbyterians, the author claimed, had neither prosecuted nor intimidated the Episcopalians, and they enjoyed every liberty of conscience they could expect to have.

The Scots nation and union vindicated; from the reflections cast on them, in an infamous libel. Entitl'd, The publick spirit of the whigs, \&c. In which the most scandalous paragraphs contain'd therein are fairly quoted, and 
fully answer'd. London: printed for A. Bell at the Cross-Keys and Bible in Cornhill; and sold by J. Baker at the Blak-Boy in Pater-Noster-Row. 1714 (published between 23 February and $29 \mathrm{March}$ ). $4^{\circ}$; 1-2 3-28 pp. (Daniel DEFOE; although sometimes attributed to George Ridpath.) $\mathrm{L}, \mathrm{E}, \mathrm{O}, \mathrm{CtY}$

The controversy between Steele (No. 93) and Swift (No. 306) essentially was a whig-tory fight over the succession and over the state of Britain both past and future. Scotland was only incidental to that matter, and the majority of the pamphlets written for or against Steele and Swift also were only marginally interested in Scotland. North Britain, however, found a traditional defender in Defoe, who took exception to those portions of the Swift work which were concerned with Scotland, and who defended that area from Swift's tory attack. The honor of the Scots noblemen was at the center of the controversy; it was this section which Swift deleted from later editions.

Scots news from London, or the treaties between the two kigdoms (!) concerning the union. [Edinburgh?]. 1707 (dated 23 January). $12^{\circ}$; both sides. L, E

News of the ratification of the Treaty of Union by the Parliament of Scotland reached London on or before 23 January 1707, when this news release was issued. It included an account of the last days of the debate, and in particular of the last debate over religion and the safeguarding of the Church of Scotland.

A Scots poem: or a New-years gift, from a native of the Universe, to his fellow-animals in Albania.... Edinburgh. 1707 (Burch II, 1-14 January). $8^{\circ}$; (i-vi) 1-30 pp. (Daniel Defoe.) E

After many months of supporting the union, Defoe in this poem sought to summarize all of his hopes for the union and to once again present to Scotland a prospect of peace and prosperity ahead. It was an optimistic, involved, and interesting work, which reflected many of Defoe's ideas about Scotland's future trade and government. Keeping in mind the state of the union controversy in January 1707, one realizes that it also was a part of the continuing barrage of material attempting to convince the Scots and the English that union would be in their best interest. This tract was answered in No. 407 .

360 Scots Presbyterian justice exemplifyed, in the case of Mr. Will. Dugud, who lately was forc'd to fly to England from their persecution in Scotland, for having accepted of a presentation from Her Majesty to the Parish Church of Bruntisland, being a full vindication of him from the malicious accusations of their Kirk Judicatories. In a letter from himself to a friend of his in Scotland. ... L London, printed by W. R. and sold by John Morphew near Stationers Hall. 1714 (dated 2 April). $8^{\circ} ; 1-23-54$ 55-64 pp. William DuGUD. L, E, DFo

While the case of Mr. Dugud might at first glance seem purely one involving internal Scottish religious problems, it was in fact the opening round of the Scottish retaliation against the imposition of patronage by the Parliament of Britain. The Scottish Presbyterian church opposed patronage, which the Anglican church viewed as necessary to the proper regulation of their church. The imposition of that procedure upon the Presbyterian 
church in Scotland despite the protections of the treaty aroused intense anger in that kingdom. In this context, the pamphlet is appropriately included. It was answered in No. 518.

361

The Scots representation to Her Majesty, against setting up the Common Prayer-Book in Scotland. [1711/1712]. $4^{\circ}$; $1-78$ blk. pp. (GroRge RidPATH; an oft-cited ms. note on E copy: "by George Ridpath and his associates Mr. William Carstares . . . and Daniel Defoe." The precise relationship of these three men is uncertain.) $\mathrm{E}$

$$
\text { [ [1712] (before } 21 \text { February). } 2^{\circ} ; 1-4 \text { pp. E, O }
$$

Passage of the Act of Toleration in 1712 was regarded in Scotland as a violation of the safeguards given to the Church of Scotland by the Treaty of Union, and was seen to weaken the Church of Scotland and to elevate the Episcopalians in that kingdom to near equality. This reprinting of the petition presented by Carstares from the General Assembly to the Queen, with some comments before and after it, was an attempt to present the arguments of that assembly to a wider audience at a time when the issue was under debate in the Parliament.

362 The Scottish historical library: containing a short view and character of most of the writers, records, registers, law-books, \&c. which may be serviceable to the undertakers of a general history of Scotland, down to the union of the two kingdoms in $\mathrm{K}$. James the VI. London, printed for T. Childe, at the White Hart in St. Paul's Church-Yard. 1702 (Arber, Hilary 1701/2; $H W L$, abstracted February). $8^{\circ}$; (i-ii) $1-4$ i-xxxix $x l$ 1-237 239238 240-256 241-342 $443344-376$ pp. William Nicolson. L, E, O, DFo, InU, MH, KU (pp. $43-44$ bound before p. i)

Encouraged by his success with The English Historical Library, Nicolson turned his attention to Scotland and to the identification and presentation of the best writers on the past of that kingdom. He included writers on Scotland's religious, political, legal, and numismatic history to 1603 . It was an elaborate, extended, and controversial work which could not hope to escape criticism from those who disagreed with Nicolson's interpretation of the theme, and with the approach of some of these writers whom he presented. The sequence of the debate stemming from this work is: Nos. 362, 235, 482, 236, 156, 450, 35, $188,160,81,451,483,238,519,422$.

363 The Scottish toleration argued: or, an account of all the laws about the Church of Scotland ratify'd by the Union-Act. In a letter from a Scots gentleman to a Member of Parliament. London: printed for S. Popping, at the Raven in Pater-Noster-Row. 1712 (dated 24 January 1711/12; Kennett, published between $21 \& 30$ January). $8^{\circ} ; 1-23-2324 \mathrm{pp}$. (Willam Carstares.) E, LU-G, CtY, DFo, InU

The bill to give Episcopalians in Scotland greater freedom of toleration in the place and form in which they might conduct services, prompted responses from Scottish Presbyterians, who bluntly complained that such a bill violated the terms of the Treaty of Union. This tract sought to condense the laws relating to the established church, and to point out 
the ways in which the bill would disrupt and threaten the security of that church and of the state as well. It was an effective if somewhat legalistic approach to the problem of the Episcopal church in Scotland. Other works in this debate include: Nos. 60, 418, 413, and 91 .

364 The Scottish toleration truly stated in a letter to a peer. London. 1712 (before 18 February). $8^{\circ}$; (i-ii) 1-18 pp. (George Mackenzle, EArL of Cromarty.) E, DFo

This tract was part of the religious controversy in Britain in 1712 relative to the position of the Episcopalians in Scotland and to the rights of patrons to fill places in the established church in Scotland. Both issues aroused great heat. This pamphlet sought to affirm the right of the British Parliament to make and to alter laws of previous Parliaments which regulated matters of religion, and to refute assertions made by Presbyterians that laws established by the union could not be altered. Finally, the author denied that any of the laws passed in any way threatened the established church.

365 Scripture-Monarchy, no tyranny. and Scripture-Loyalty, no slavery. Or, a brief examination of the non-resistance, as asserted by $\mathrm{A}$. C. in a sermon on January XXX. at Edinburgh. ... 1712. $8^{\circ}$; (i-ii) $1-50$ pp. (Dedication by "Philalethes.") $\mathrm{E}$

The Episcopalians in Scotland were particularly fond of reflecting badly upon the Presbyterians, who were called republicans and religious fanatics; upon William IIl, who allowed the Episcopalians to he disestablished; and upon the revolution of 1688 . These attitudes were often present in the sermons of Andrew Cant, and were the bases of this tract in vindication of the Presbyterians and against Cant. It was predominantly a theological work, but it did reflect larger issues, and so is included.

366 Scrub, scrub: a poem in praise of the itch: with a word or two in favour of brimstone. London printed, and sold at the Publishing-Office in Bearbinder Lane. 1707. $1 / 2^{\circ} ; 1-2$ pp. (HenRY Cross-Grove.) O, DFo

$\begin{array}{ll}\text { one side. } & \text { London, printed by R. Wilson, near Ludgate-hill. } 1707.12^{\circ} \text {; }\end{array}$

[variant:] Scrub, scrub, a poem ... the itch; with.... Norwich: printed by Hen. Cross-grove. [1707]. $1 / 2^{\circ}$; both sides. NwP

This rather furious little poem was most uncomplimentary in its references to Scotland; indecd, the people of Scotland were accorded all of the usual bad characteristics-the itch, mange, a taste for bad food, and the like. The poem itself was of no particular merit.

A seasonable advice, to all who encline to go in pirrating; drawn from what has happ'ned to Captain Green, as it were from his own mouth, one of that rank. To the tune of, To the weaver if ye go, \&c. [Edinburgh? 1705]. $1 / 2^{\circ}$; one side. $\mathrm{E}$

This doggerel attempted to take advantage of the outery in London against the scizing of the Worcester, and the trial and hanging of an Englishman, Captain Green, accused of an 
act of piracy. In London he was thought a victim of enraged Scots and of injustice, while in Scotland it was thought that the English wcre attempting to protect one of their own nation who was in fact guilty of piracy. The song leans to the Scots' side of things.

A seasonable alarm for Scotland: in a letter from a gentleman in the city, to his friend in the countrey: concerning the present danger of the kingdom, and of the Protestant religion. [1703] (dated 11 October). $2^{\circ} ; 1-4$ pp. $\mathrm{E}, \mathrm{KU}$

Fear of France, of Roman Catholicism, and of political oppression all were combined into a fear of Jacobitism which was to remain throughout much of the first half of the century. This pamphlet was predominantly such an anti-Jacobite paper, but it considered some of the difficulties between England and Scotand in 1703 and before as part of the overall Jacobite problem; and it did declare that it was the Jacobites who had caused that friction and who had benefited from it.

369 A seasonable caution to the General Assembly. In a letter from a Member of Parliament of North-Britain, to a minister in Scotland: occasioned by the House of Lords reversing the sentence of Mr. Greenshiels. [Edinburgh. 1711] (E ms. note, 8-9 March). $8^{\circ}$; 1-2 3-31 32 pp. (Daniel Defoee.) E, $\mathrm{CtY}$ (errata slip mounted on p. 31)

The decision of the British House of Lords to reverse the judgment in the Scottish courts against the Episcopalian Rev. James Greenshields heartened the Episcopalians as much as it discouraged and enraged the Presbyterians in the north. With all of the ingredients for an outburst of rage and hatred by the Presbyterians-provoked by the ill-timed gloating of the Episcopalians-the situation called for calm words and for the encouragement of moderation, common sense, and toleration. This author attempted to damp down the fires and to soothe the tempers of men not accustomed to being restrained.

A seasonable suggestion arising from the grateful reflexion upon Her Majesties resolution, the Lords agreement, and the Commons determination on it, to let the Dissenters quietly enjoy that indulgence which the law hath allowed them. To improve our union. Set forth, that the concern so momentous should come into the consideration of the Legislature, when business gives leisure, and time serves it, in this present, or another future session of Parliament. London: printed for W. Wyat, at the Bible in High-Holborn, overagainst Little Turn-Stile; and sold by J. Morphew, near Stationers. Hall. 1711. $8^{\circ}$; 1-2 3-22 pp. (JoHn Humfrey.) L, O

John Humfrey again advanced his plan for a National Church in which Presbyterians, Episcopalians, and Independents could be united under the monarch. These three separate churches all were to be allowed by law within the kingdom, and therefore would together constitute one church while conducting separate services.

The seasonable warning of the Commission of the General Assembly, concerning the danger of Popery, defended, against the frivilous and false remarks published in the Post-Boy. London, printed for Andrew Bell, at the 
Bible and Cross-Keys in Cornhill; and sold by J. Baker, in Pater-noster-row. [1713] (ca. 28 August). $2^{\circ}$; 1-6 pp. E, O

[variant:] A seasonable warning by the Commission of the General Assembly of the Church of Scotland, concerning the danger of Popery, at Edinburgh, August 19, 1713. Reprinted at London, for D. Brown in Nevil's Alley, in Fetter-Lane. 1713. $2^{\circ}$; 1 (verso blank), 2 (v. blk.) 3 (recto blk.) pp.

This work was in answer to the issues of The Post Boy of 10, 12, and 15 September 1713, in which detailed exception had been taken to a warning by the General Assembly about the growth of Popery in Scotland. The Post Boy attempted to equate the Presbyterians with those disloyal to the Queen, determined to destroy Anglicanism and Episcopacy, and disruptive to government. The Post Boy, in defending the incumbent Tory government, prompted this reply, which inevitably was a difficult onc; for it had to defend the church as loyal while at the same time attacking the ministry and its spokesman who had accused the Assembly of devious actions.

372 A seasonable warning or the Pope and King of France unmasked. [Edinburgh]. 1706 (Moore; E ms. note, 25 November). 4; 1-3 4-16 pp. (Dantel Defoe.) L, E, O, LU-G, CtY

Defoe began his argument for union with a realistic appraisal of the prospects of Scotland outside the union. After presenting a bleak picture of the economic future of Scotland alone in the world, he contrasted it with the economic, as well as the political and the religious advantages, to be gained by the union. In conclusion he argued that the opponents of union included the papists and the French. It was a strong pamphlet, heavily weighted toward economic considerations.

373 A second defence of the Lawful prejudices, containing a vindication of the obligation of the National Covenant and Solemn League, in answer to a letter from the country, \&c. Written by the minister of Humby. [1707]. $4^{\circ}$; 1-12 pp. (James WebsTer.)

E

Webster held rather strong views on the question of the national league, and in this tract sought to refute arguments advanced by Adams (in No. 222) which were in contradiction to his own beliefs. The issue in question was the degree to which swearers to that oath could enter into a union with England, sinful as it was and unacceptable as the treaty made it. Webster answered Adams, line by line, in a tedious restatement of the obligations imposed upon all who had taken the oath, and the various interpretations of that oath over the past century. Adams originally had answered Webster's No. 187. Webster then wrote this tract, to which Adams replied in No. 377.

374 A second defence of the Scotish Vision. [Edinburgh]. 1706 (Foxon, December?) $1 / 2^{\circ}$; one side. (John Hamilton?) L, E, InU, MH

With this poem matters were brought directly home to Defoe, whose identity was revealed within the poem. The author of this picce did not hesitate to label Defoc ungrateful and false, and to expose his often-repeated declarations of intent to remain in Scotland. The participants in this little controversy were beginning to lose control of their tempers and to engage in personal assaults. The original speech, No. 241, was answered by Nos. 88 
and 398, as well as by Defoe's No. 30, which was followed by Nos. $525,355,332,374$, and 118.

A second dialogue betwixt a minister of the Church of Scotland, and two of the elders of his congregation, concerning the Abjuration-Oath: wherein the former dialogue is defended from some objections that have been made against it, and the objections against the oath taken from the design, reference, penalties, and offence of it; as they are stated in a late essay, are fully answered. ... Edinburgh, printed by John Moncur, and sold by William Brown bookseller, at John Vallange's shop opposite to the entry to the Parliament-Closs. 1713 (after April). $8^{\circ}$; (i-iv) $12-84$ pp. (James Smith.) E

This dialogue sought to ease the minds of those who had taken the oath by examining objections to that oath in Scotland and by discussing the works written for or against the oath since the publication of the first dialogue (No. 101). The author took his task seriously, and in this extremely wordy and involved essay sought to remove all doubts and fears and to reinforce the resolve of the elders to take the oath without reservation or objections. Cf. Nos. 126 and 521.

376 A second essay concerning the land mint, shewing, that the present necessity, and want of gold and silver money, absolutely requires this, or the like remedy, and that speedily. As also holding forth the equivalency of the land-mint money, to gold or silver money, and the sufficiency thereof, for all the uses and ends of money. With an introduction, clearing how the establishment of this land-mint, will prove the most proper way to carry on all national improvements and trade, in this conjecture. By the author of the Character of the true publick spirit. Edinburgh printed by Mr. Andrew Symson. 1705. $8^{\circ}$; (i-xxiv) 1-39 40 blk.pp. (ANDRew Brown.) L, CtY, MH

This tract by Brown was primarily concerned with Scotland's inadequate banking and currency structure, and the resulting problems which this meant for trade and industry. The attempt to find ways out of this financial bind would culminate in the debates over the union, when many would be eager to exchange an inadequate cconomic base for political independence. This was reprinted in No. 457. Cf. Nos. 123 and 345.

377 A second letter from the country, in vindication of the former concerning the National Covenant and Solemn League: in answer to a pamphlet entituled, Lawful prejudices against an incorporating union with England. 1707 (dated 10 April). 4; $1-3$ 4-23 24 pp. (William Adams.)

$\mathrm{E}$

This last restatement of the Adams-Webster debate carried their already confused and acrimonious argument to a final level of disagreement. Webster held to his view that the Solemn League and Covenant obliged men to disavow the union with England, while Adams denied that interpretation. The issue turned in part on events in 1638-1639 and on differing interpretations of the covenant and of its impact upon civil and ecclesiastical ministers. The debate had started with Webster's No. 187; Adams replied in No. 222, to which Webster answered with No. 373. Adams finished the debate with this tract. 
378 A second letter, on the British union. [Edinburgh? 1706]. $4^{\circ} ; 1-16$ pp. (George Mackenzie, Earl. of Cromarty.) E, O, InU

[variant:] (This copy has a postscript, which the above does not. The catchword on A4, verso is the same, but the content of the sentence is changed.) 1706 (dated 8 April). $4^{\circ}$; $1-18$ pp. $\quad \mathrm{E}$

Like his first (No, 212), Mackenzic's second letter sought to defuse arguments against union among Scotsmen. He urged an incorporating union, and tried to show that sucl a union would not mean the devastation and disruption or loss of honor predicted by its enemics. The arguments against the union which were advanced and then rejected were of the more general and popular sort, and the letter was directed more in that direction than to the more sophisticated audience in Scotland. It was reprinted in No. 501.

379 The secret history of the Geertruydenbergh negociation. With several original papers. To which are prefix'd Two letters. I. To the Rt. Honble Robert Harley, Esq; concerning the management of the present ministry. II. To the Rt Honble the Lord Privy Seal, relating to the present treaty of peace now on foot. Done out of French. . . . London. 1712 (ca. 1 December 1711 ). $8^{\circ}$; (i-ii) $1-94$ pp. (Anonymous, although sometimes attributed to Abel Boyer.) L, CtY, MH, KU

[variant:] ... Geertrudenbergh. ...

MH

[idem] The secret history of the Geertruydenbergh negotiation. With several original papers. To which are prefix'd two letters. I. To the Earl of Oxford. II. To the Lord Privy-Seal. The second edition. To which is added, the history of the peace from the arrival of M. Mesnager, Sept. 18. 1711, to the return of the Earl of Strafford, from Utrecht, May 15. 1712. Wherein the proceedings of both Houses of Parliament are inserted; and the reasons for and against it fully consider'd. Done out of French. London: printed for E. Curll, at the Dial and Bible against St. Dunstan's Church in Fleetstreet. 1712. $8^{\circ}$; (i-ii) 1-94 1-49 50, errata, advt. pp. CtY

By 1712 the management of foreign affairs had become a matter of considerable controversy between the displaced whigs and the victorious tories. Although this pamphlet is not about Scotland as such, it contains in the first letter an account of the interaction of Scotland and England from the passing of the Act of Security in Scotland to the eventual passage of the Act of Union and beyond. The overall intent was to vindicate the government then established from charges against them relative to both external and internal affairs.

380 The secret history of the October-Club, from its original to this time. By a member. Part II. London: printed for J. Bbker (!), at the Black-Boy in Pater-noster-Row. ... 1711. $8^{\circ}$; (i-ii) 1-93 94 blk. $95-102$ pp. (H4, books printed for Baker). (Daniel Defoe.) E, CtY, KU

$\mathrm{L}, \mathrm{O}, \mathrm{DFo}$, InU

lacking sig. H. 1711 (Moore, 23 June). $8^{\circ}$; (i-ii) $1-9394$ blk. pp. 
In this pamphlet Defoe was more interested in high church, tory policies than in Scotland as such, and it is included more for occasional passages than for any sustained themes. Defoe, however, was one of the most knowledgeable Englishmen on the subject of Scotland and he was much more likely to include comments on Scotland than most of the pamphleteers of his day. On page 65 he repeated the well-known statement that Englishmen knew more about Japan than they did of Scotland, and therefore would believe anything of it. He was quite correct in that observation.

381

A sermon preach'd at Penrith, not far from the confines of the two united kingdoms, on Thursday May 1. 1707. Being the thanksgiving-day for the happy union of England and Scotland. London, printed for Jonah Bowyer, at the Rose in Ludgate-Street, near St. Paul's. 1707 (published before the end of May). $4^{\circ}$; 1-4 5-22 pp. Hugh Tond. L, E

Despite his reputation for controversy and confrontation, Todd in this sermon emerged as a rather tolerant man who knew the border history of. England and Scotland, and who saw the union as finally bringing to a conclusion that long and bloody story. He was an Anglican, and did not retreat from that position; but it was a more moderate sermon than one would have expected from him.

382 A sermon preach'd at Richmond in Surry, on Thursday the first of May, 1707. Being the day appointed by Her Majesty for a general thanksgiving, for the happy union of the two kingdoms of England and Scotland ... Publish'd at the request of the auditors. London: printed for J. Chantry, at the sign of Lincolns-Inn Square, at Lincolns-Inn Back-Gate. 1707 ( $H W L$, April; published ca. 16 May). $8^{\circ}$; (i-ii) $1-1314$ blk. pp. Nicholas Brady. L, E, O, DFo, InU

Brady was anxious to make the best of the union, and he stressed its positive aspects: a certain succession, unity against papists, and security for the Church of England. He lamented the incompleteness of that union in matters of religion, and hoped that further unity might be achieved. Of course it would be an Anglican unity, but at least the sermon was not an attack upon the Presbyterians of Scotland.

383 A sermon preached at St. Edmund's-Bury, on the first of May, 1707. Being the day of thanksgiving for the union of England and Scotland. Publish'd at the request of the corporation. London: printed for D. Midwinter at the Rose and Crown in St. Paul's Church-Yard, and R. Watson, Junior, bookseller in Bury. 1707. $8^{\circ} ; 12-16$ pp. Francis Hutchinson. L, CtY

A fashionable Anglican minister, Hutchinson preached a moderate sermon which stressed reconciliation and the alleviation of historical problems and differences. He frankly recognized that religion was the great problem remaining, but argued that the Church of England had not lost its historical protections nor had it been diminished, but rather enhanced by the union.

384 A sermon preach'd at the New Chapel in Ormond-Street, upon Thursday, May the first, 1707, being the day of thanksgiving to Almighty God 
for the union of the two kingdoms of England and Scotland. And at the Parish of St. Mary Aldermanbury the Sunday following. Publish'd at the request of several in each audience. London: printed for Robert Clavel, at the Peacock in St. Paul's Church-Yard. 1707. $4^{\circ}$; (i-vi) 1-17 18 blk. pp. NathaNiel Marshall. L

This moderate Anglican clergyman stressed the best possible aspects to the union. He argued that it would assist in the war against France and against Popery, that Scotland certainly was a worthy partner, that the Church of England had lost nothing by the union, and that good works and good examples could bring the two religions closer together.

385 A sermon preach'd at the Parish Church of St. Dunstan's in the West London, on the first of May, 1707. Being the thanksgiving-day for the glorious and happy union of the two kingdoms of England and Scotland. London: printed for W. Rogers, at the Sun against St. Dunstan's Church in Fleetstreet. 1707 (HWL, April). $4^{\circ}$; (i-iv) 1-24 pp. John Grant. L

Grant waxed eloquent on the blessing of a union. Hc saw the Scots as an acceptable people, and thought that the union would aid trade and commerce and increase the wealch and power of a unitcd Britain. Above all, it would protect religion and assist in defeating the French, whom he regarded with extreme loathing.

386 A sermon preach'd before the Queen at the Cathedral-Church of St. Paul, on May the first, 1707. Being the day appointed by Her Majesty for a general thanksgiving for the happy union of the two kingdoms of England and Scotland ... Publish'd by Her Majesty's special command. London, printed by J. B. for Jonah Bowyer, at the Rose in Ludgate-street. 1707 (HWL, April; published ca. 7 May). $4^{\circ}$; (i-iv) 1-28 pp. William Talnor. L (lacking half title page), InU

. London: printed by J. B. for Jonah Bowyer, at the Rose in Ludgate-street. $1707.8^{\circ}$; 1-2 3-16 pp. L, E, O, CtY, DFo, InU, MH, KU

. London: printed and sold by the booksellers of London and Westminster. 1707. $8^{\circ} ; 12-16 \mathrm{pp}$. O, CtY, MH

[variant:] . . happy union between England and Scotland. . . L London: printed by J. B. for Jonah Bowyer, at the Rose in Ludgate-street. 1707. $8^{\circ}$; 1-2 3-16 pp. L, O

Talbot's one major objective was to avoid anything which might displense Anne or reflect upon her politics. As a past master of the art of writing such sermons, he praised everyone even remotely concerned with the union, avoided any issue which might have been controversial, and ignored the question of religion, which had evcryone else upset.

387 A sermon preach'd before the University of Oxford, on the first of May, 1707. Being the day appointed for a general thanksgiving for the happy union of the two kingdoms of England and Scotland. London: printed for 
Tim. Goodwin, at the Queen's-Head against St. Dunstan's Church, Fleetstreet. 1707 (ca. 10 June). $4^{\circ}$; (i-iv) 1 2-19 20, advt. pp. Chardes Bean. - L, O

Bean was most unfortunate to have both the whigs and the tories in Oxford attack his sermon when it was delivered, and this publication was an attempt to counter rumors about it from his colleagues there. He tried to prove that he had slighted neither Anne by criticizing the union, nor William by reflecting upon his policies toward the Presbyterians. His sermon, therefore, stressed loyalty to Anne, respect for William, distaste for Scotland, and support for the union-reluctant but nonetheless forthcoming.

388 A sermon preached in St. George's Church in Doncaster, May I. Being the day of thanksgiving, for the wonderful and happy conclusion of the Treaty for the Union of Her Majesty Queen Ann's two kingdoms of England and Scotland ... Published at the request of the Worshipful Mr. Mayor, the Aldermen, and other gentlemen, the hearers. London, printed for W. Taylor, at the Ship in St. Paul's Church-Yard and are to be sold by Fr. Hillyard, in York. 1707. $4^{\circ}$; 1-2 3-24 pp. P.D. (Patrick Dujon.) L

This minister was a high, high, high tory Anglican who regarded the union, the Scots, the Presbyterians, and just about everything else about this affair with extreme repugnance. He accepted the authority of the Queen, and therefore accepted the union as her command; but the best he hoped for was the conversion of the Presbyterians to Anglicanism.

A sermon preach'd May 1. 1707. Being the day of thanksgiving for the union of the two kingdoms of England and Scotland. London, printed for A. and J. Churchill at the Black Swan in Pater-noster-row. 1707 (ca. 19 July). $4^{\circ}$; (i-vi) 1-26 pp. Joseph Standen.

L, O. CtY

Moderation and a reformation of manners were the two key phrases in this sermon which urged that extremists should be avoided, that a moderate church should be sought by all in the new union, and that-most important-all would benefit by a reformation of manners and a return to Godly ways.

A sermon preach'd May the 4th. 1707. at Uxbridge, upon occasion of the late day of thanksgiving for the union of the two kingdoms of England and Scotland. London, printed for R. Borough, and J. Baker, at the Sun and Moon in Cornhill. 1707. $8^{\circ} ; 1-23-2324$ pp. John Olly

$\mathrm{O}$

Ollyffe attempted to reconcile all who were opposed to the union, and in particular to soothe the dissenters who might have been disturbed by it. The sermon stressed the positive advantages of the union and Anne's support for it, as well as the need to support authority. A union on even the most imperfect terms was better than no union at all.

391

A sermon preach'd on the first of May, 1707. Being the day appointed for a publick thanksgiving for the happy union of England and Scotland. London: printed by J. Darby, and sold by J. Baker at MercersChappel in Cheapside. 1707. $4^{\circ} ; 1-23-32$ pp. Joseph Stennetr. L, O, $\mathrm{CtY}, \mathrm{DFo}$ 
. London; printed by J. Darby, and sold by J. Baker at MercersChappel in Cheapside. 1707. $8^{\circ}$; 1-2 3-16 pp. L, E (lacking pp. 5-6), InU

Stennett, a dissenter, was extremely cautious in his sermon; his focus was narrow, limited primarily to appropriate textual criticism and to vague generalizations that would be inoffensive. While aware of the problems remaining after the union, Stennett did not feel free to pursue them.

392 A sermon preached on the publick thanksgiving for the incorporating union of England and Scotland. London. 1707. $2^{\circ} ; 1-23-2324$ pp. George Burnet. InU

Burnet, like most prenchers on 1 May, tended toward a glorification of God and monarch as the essential theme for that day. The union would halt internal warfare, unite all Protestants against Catholicism and France, secure the Hanoverian succession, strengthen Anne, and honor God who wrought peace and harmony among men.

A sermon preach'd on the thanksgiving day, for the happy union of Great Britain. SEE: No. 46.

393 A sermon preach'd to the people, at the Mercat Cross of Edinburgh; on the subject of the union.... [Edinburgh]. 1706 (Beattie, December). $4^{\circ}$; 1-3 4-20 pp. (John Arbuthnot.) L, E, O, LU-G, CtY, InU, MH

[variant:] . . Mercat-Cross. . . L London, printed for Andrew Bell at the Cross-Keys and Bible in Cornhill. 1707. $8^{\circ}$; 1-2 3-16 pp. L, E, O, LU.G, $\mathrm{InU}$

London, re-printed for Andrew Bell at the Cross-Keys and Bible in Cornhill. 1707. $8^{\circ} ; 1-23-16$ pp. KU

London; re-printed for Andrew Bell at the Cross-Keys and Bible in Cornhill. 1707 (HWL, December 1706, January 1707). $8^{\circ}$; 1-2 3-16 pp. DFo

[variant:] ... sermom.... London; re-printed for Andrew Bell at the CrossKeys and Bible in Cornhill. 1707. $8^{\circ}$; 1-2 (advt., p. 2) 3-16 pp. $\mathrm{MH}$

$$
\text { np. nd [1707]. } 8^{\circ} ; 1-8 \text { pp. L, O }
$$

The most famous of all the sermons on the union was never delivered nor was it ever written to be delivered. Arbuthnot, while one of the most famous Scots in London, was not particularly concerned with the Scottish question, and this is his most important contribution. It is a masterly argument for the union by a professional writer of prose, and all the more important arguments for the union are to he found here.

394 A sermon upon the union of the two kingdoms, preached in the Parish Church of St. Andrew Holborn, May the 1st, 1707. London: printed by J. Downing, for S. Smith and B. Walford, printers to the Royal Society, at the Prince's Arms in St. Paul's Church-Yard. 1707. $8^{\circ} ; 1-2$ 3-11 $1013-16$ pp. Thomas Manningham. L, E, O, DFo, InU 
Manningham was an Anglican clergyman, rcluctant to apply labels to anyone. He was a reasonable, moderate, rational man who sought to convert by example rather than by force, and this sermon reflected those characteristics. It was a sermon which looked at every side of the question, and which sought to reconcile rather than to divide.

395 Several grievances given by a countrey man, ancnt decay of trade within the kingdom of Scotland. [1703]. $12^{\circ}$; one side.

$\mathrm{E}$

This extremely unsophisticated paper on the decayed state of the Scottish economy echoed the usual lament that Scotland had declined in recent years, and suggested halting that decline through an attack upon sloth and neglect. The drain upon currency by the failure of the Company of Scotland, as well as exports into England, had to be reversed, and the poor employed. It was a plea for full employment, restrained imports, expanded exports, industry and enterprise at home, and currency regulations and controls.

396 Several proposals conducing to a farther union of Britain: and pointing at some advantages arising from it. London. $1711.4^{\circ}$; (i-ii) 1-22 pp. (George Mackenzie, Earl, of Cromarty.)

Cromarty wrote often and well on numerous topics. This piece combined his interest in Scotland and fishing, salt and salt taxes, the union, religious toleration, and patronage. Fishing he regarded as the great hope of Scotland; it could make her as rich as the Netherlands, because all the natural requirements for beating the Dutch were available. The problem of salt, however, continued to perplex all, and this he discussed thoroughly. Finally he added a section promoting religious toleration and urging the acceptance of patronage. His concluding remarks on their lack of popularity in Scotland would not have endeared him to Presbyterians.

397 Several reasons why the succession ought not to be declar'd by this Parliament, and all objections to the contrary answer'd. Humbly offer'd in an address to the Members of Parliament. [Edinburgh]. 1704. 4 ; 1-2 4 4-8 pp. L, E, O, LU-G, DFo, InU, MH

This work argued against the settling of the succession in Scotland, on the grounds that the members had received no such authorization, that an unsettled succession would force the English to make concessions, that it would endanger Anne, and that it would give Scotland even less prestige and leverage internationally. Every effort was made to arouse the pride of the Scot and to present the English in as unfavorable a light as possible; the author undoubtedly was a Scot or one inclined toward their interest as he saw it.

398 She put her hand upon his scull, with this prophetick blessing, Be thou dull, \&c. [Edinburgh. 1706] (early December?). $1 / 2^{\circ}$; one side. (Ellis, possibly by William Anstruther). E, $\mathrm{MH}$

This lampoon against Lord Belhaven and his speech against the union took as its theme the stupidity of that nobleman. The attack was personal, but not without some touches of humor. 'This, like Nos. 30 and 88 , was an answer to No. 241 , as well as to No. 355 . 
also some: notice is taken of their chief cities and royal boroughs. With an appendix, I. About their king's supremacy. II. The difference of the Scotch and English liturgy. III. The revenue and expense on the civil and military list, according to a late establishment. London, printed for Tho. Newborough, at the Golden Ball in St. Paul's Church-Yard. 1702 (ca. 20 May; HWL, abstracted, August). $8^{\circ}$; (i-iv) 1-156 pp. (Thomas Morer.) L, E, CtY, $\mathrm{MH}, \mathrm{KU}$

- London, printed and sold by B. Bragg at the Raven in Paternoster-Row. 1706 (HWL, April). $8^{\circ}$; (i-iv) 1-156 pp. InU

Of all the accounts of Scotland as it was in the reigns of James II and William III, this is the most valuable and most comprehensive. The author, an Anglican clergyman, attempted to present as objective a view of Scotland as he could, but it obviously reflected some of his own prejudiccs. It is invaluable, however, to all students of the period for its examination of the religious, economic, political, and cultural life in Scotland.

400 A short account of the grievances of the Episcopal clergy in Scotland. London. 1712 (E ms. note, April). $4^{\circ}$; 1-2 3-1920 blk. pp. E, O

Agitation in England for a toleration in Scotland for the Episcopal clergy was such by 1711 that pamphlets came from the presses in a stendy flow. This particular work was an explanation and plea for the Episcopalians in Scotland, and was written to justify the actions of that group in earlier reigns and to defict criticism of them by the Presbyterians. The violence of the Presbyterians in 1688 was contrasted with the leniency of the Episcopalians in the rcign of Charles II.

401 A short account of the passing the twenty five articles of union betwixt Scotland and England. [Edinburgh]. 1707 (dated 12 February). 1/2 ${ }^{\circ}$; one side.

This short account really was more of a news bulletin than anything else. It relayed the news of the ratification by the Parliament of Scotland of the articles of union, and the payment of an allowance to the commissioners for their work.

402 A short account of the union betwixt Sweden, Denmark and Norway, which commenced about the year 1396, and was broke about the year 1523. Taken from Puffendorf's History of Sweden p. 85. Printed at London 1702. Fit to be perus'd by Scotsmen at this juncture; and published for the benefit of such as have not access to the book. [Edinburgh. 1706]. $4^{\circ} ; 12-4$ pp. (Anonymous; taken from the work of Samuel von Pufendorf.) L, E, LU-G

Scandinavia was of great interest to the English and the Scots during the reign of Anne, and the nature of its governments as well as the history of the union of Sweden, Denmark, and Norway interested many who were contemplating a union of England and Scotland. The comparisons usually were not encouraging, and were favorites among opponents of the union at home. 
403 A short but true account of the nobility and representatives of that ancient realm and kingdom of Scotland, their actings and proceedings, together with their unnatural and unmanful yielding and complying with these un-Christian demand of England, I mean that union, lately made betwixt Scotland and England, contrar to the written laws of God, \& to our claim of right, clean contrar to our predecessors valiant and heroick actings, both in church and state; together with the authors dedication to the Scots chapmen that have sold their crown and scepter, and all their rights and priviledges, both sacred and civil, for a little sum of money, that will not be a babie to every one in Scotland. At the desire of the godly and loyal party. Written by an impartial pen, collected and drawn up by Robert Ker, in 1705. At the time of my Lord Balhavens worthy speech (or prophesie) to the Parliament of Scotland. [Edinburgh?]. 1712. $8^{\circ}$; 1-2 3-16 pp. Robert Ker of Gilmerton.

E, DFo

Ker was a devoted writer of bad verse, most of which had an uncompromisingly religious flavor. He was a man who vicwed all compromise with the greatest regret, and this pocm against a union combined his admonitions with a certainty of damnation for all who compromised in matters of religion.

404 A short essay upon the limitations to prove that they are so far from being of any consequence to the nation, that they may tend very much to its prejudice. Edinburgh. 1703. $4^{\circ}$; 1-2 3-16 pp. (John Clerk.) E, LU-G

The questions of limitations upon the monarch, the succession, war with France, and union with England all preoccupied the Scots in 1703, and Clerk sought to put all these issues into perspective, to dampen enthusiasm for limitations, and to point out the danger inherent in hasty or ill-advised action. The degrec to which Scotland could act either with or independent of England was critical to all discussions in the tract. It was a tightly argued work, packed with common scnse. Cf. No. 433.

405 A short history of the revolution in Scotland. In a letter from a Scotch gentleman in Amsterdam to his friend in London. London printed: and sold by the booksellers of London and Westminster. 1712 (dated 26 March, N.S.; Kennett, 26 March; $H W L$, January-March). $8^{\circ}$; 1-2 3-16 pp. (Jorn Cock burn; also sometimes attributed to Charles Leslie.) L, E, O, $\mathrm{CtY}, \mathrm{InU}, \mathrm{MH}$

This short account of the events leading up to and following the revolution of 1688 to the union of 1707 is an interesting example of a Jacobite approach to the history of Scotland during those years. William III and the Presbyterians were dealt with most severely, while James II and the Episcopalians were approached in a much more laudatory fashion. The Act of Union was termed totally unacceptable as detrimental to the interest of Scotland and to the monarchy. In its appeal this pamphlet would have been of interest primarily to convinced Jacobites and to those seeking reasons to identify the Episcopalians with the Jacobites.

406 A short letter to the Glasgow-Men. [Edinburgh. 1706] (Healey, between 9 and 12 December). $4^{\circ}$; 1-8 pp. (Daniel Defoe.) E, CtY 
The author of this tract cannot be denied a superb sense of style and occasion, for he most skillfully exposed those in Glasgow who were violently against the union as companions to the Jacobites and papists, whom they accused of being enemies of the church. In a few short pages the author attempted to demonstrate that opposition to the union was not in the best interest of the Church of Scotland. The opponents abandoned the principles and ideals for which they were known in Scotland.

407 A short satyre on that native of the Universe, the Albanian animal, author of the New-year's gift, or Scots pocm upon the Union. [Edinburgh? 1707]. $1 / 2^{\circ}$; one side. E

Defoe's Scots Poem (No. 359) did not please everyone and this response to it stressed all that was weakest in the pocm: its doggerel poetry, its fatal optimism, its grand flights of fancy. Defoe the optimist did not always provoke the best response from Scots who viewed the union in a much more subdued light.

408 A short view of our present trade and taxes, compared with what these taxes may amoung to after the union, even tho our trade should not augment one sixpence. With some reasons, why (if we enter in an union,) our trade should be under our own regulations. [Edinburgh. 1706]. $4^{\circ} ; 1.8 \mathrm{pp}$. (William Black.) L, E, O, LU-G, CtY, InU, MH

This author was primarily concerned with the impact of the increased taxes which would fall upon Scottish trade after the union. He argued that prosperity was based on industry and trade and that those prospered most who were able to trade with the least restrictions. He thought that the heavier English taxes, when levied upon Scotland, would produce a decayed state in Scotland which would not easily be remedied. He therefore sought to have trade and industry remain under Scottish control. The debatc between Black and Defoe spreat in many directions; but if one breaks down the sections dealing directly with this work, one finds that they follow three main streams. Defoe first answered in No. 138 (which also answered Nos. 340, 419, and 130). His second answer came in No. 85, which Black responded to in No. 533. Finally he wrote No. 193, which answered this and Black's other tract, No. 412, as did No. 85. To that Black answered in No. 26. Black's No. 191 answered Nos. 138 and 85; Defoe then wrote No, 135. Black countered with No. 299, and with No. 331, which also dealt with Nos. 103 and 15.

409

A short view of the present statc of the Protestant religion in Britain, as it is now profest in the Episcopal church in England, the Presbyterian church in Scotland, and the dissenters in both. Edinburgh. 1707 (Lee; Moore, March). $8^{\circ}$; 1-2 3-48 pp. (Daniel Defoe.) L, E, O, CtY

[idem] The dissenters vindicated; or, a short view of the present state of the Protestant religion in Britain, as it is now profess'd in the Episcopal church in England, the Presbyterian church in Scotland, and the dissenters in both. In answer to some reflections in Mr. Webster's two books publish'd in Scotland. London. 1707 (ca. 1 April). $8^{\circ}$; (i-ix $x$ blk.) 3-48 pp. CtY, InU

The complicity of the Presbyterians in England with Episcopacy, and the place of the discstablished religion in Scotland before or after 1688 remained a critical issue even after 
the articles of the union were settled. Webster, by attacking the loyalty of the English Presbyterians, had opened up the controversy surrounding the Episcopalians in Scotland. The entire problem of the loyalty of any disestablished religion either in England or in Scotland was of great interest in 1707 , and it was this problem of loyalty to monarch or to religious principles that was at stake in this tract. Defoe sought to bring somc measure of common sense to the controversy, but with limited success. This was one of four answers to Webster's No. 187, the others being Nos. 109, 499, and 222.

410 Sir George M'Kenzie's arguments against an incorporating union particularly considered, as they are in his observations upon James 6. Parl. 17. ... Edinburgh. $1706.4^{\circ}$; 1-2 3-16 pp. (David Symson; usually attributed to Andrew, his father.) L, E, O, LU-G, DFo, InU, MH

The arguments advanced in the press that the existing Parliament of Scotland could not accept terms which would lead to its demise and to the loss of sovereignty for Scotland without the approval of the electorate, were here considered and dismissed as impractical, unwise, and illogical. The sequence of the debate was: Nos. 192, 140, 410.

411 The smoaking flax unquenchable; where the union betwixt the two kingdoms is dissecated, anatomized, confuted and annulled. Also that good form and fabrick of civil government, intended and espoused by the true subjects of the land, is illustrated and held out. ... 1706. $4^{\circ} ; 1-34-8910-24 \mathrm{pp}$. $\mathrm{L}, \mathrm{E}, \mathrm{InU}, \mathrm{MH}$

$$
\text { 1706. } 4^{\circ} ; 1-23-2526 \text { blk.pp. E, DFo, MH }
$$

For those who opposed union in Scotland, the Treaty of Union provided ample examples of what were regarded as sinful, harmful, and insulting terms. This author had no doubt at all that the articles as written would lead Scotland into ruin and hell as well, and that cvery possible means, including prayer, should be used to divert God's wrath from His people.

412 Some considerations in relation to trade, humbly offered to His Grace Her Majesty's High Commissioner and the Estates of Parliament. [Edinburgh]. 1706. $4^{\circ}$; 1-2 3-15 16 pp. (William Black.) L, E, O, LU-G, $\mathrm{CtY}, \mathrm{DFo}, \mathrm{MH}$

Black strongly felt that Scotland was in a unique position to exploit her potential and thus to acquire wealth, but he feared that the union would prevent that achievement unless altered. He wanted Scotland to have management of that part of trade which was hers alonc. If this were not granted, he prophesied disaster for fishing, for wool, and for many other segments of the Scottish trade and industry. Taxes would be higher once English rules prevailed, and this alone would place Scotland under unsupportable burdens. For Black at least, union would not bring the great prosperity that some foresaw. To this pamphlet Defoe devoted parts of No. 193 (to which Black answered in No. 26) and No. 85, which Black responded to in Nos. 533 and 191. Defoe then wrote No. 135 and Black No. 299. 
Attempts by the Presbyterians of Scotland to defend their established church there against the bill for tolcration of Episcopalians in turn provoked the Anglicans to defend that bill. This author sought to counter arguments against the bill and to present both rational and irrational arguments for it. In essence, the author could not accept nor explain the subordination of the Episcopal Church of Scotland (so closely akin to the Church of England) to a Presbyterian establishment. While willing to debate on rational grounds from time to time, the author gave way to passion and spleen on several occasions. Other works on this subject include Nos. $363,60,418$, and 91 .

414 Some cursory remarks on a late printed paper, called, The last speeches and dying-words of Captain Thomas Green, commander of the ship Worcester; and of Captain John Madder, chief mate of the said ship, \&c. Shewing not only the gross and manifest falshoods of these imposture-speeches; but likewise, how they are inconsistent with themselves, even altho' they had been genuin, as they are not. Containing also, a real and short account of the unbecoming and lamentable behaviour of these wretched criminals, before, at and after their trial, till the very hour of their execution on Leith-Sands, the 11th day of April 1705. Together with, a clear tho' transicnt confutation of all the scandalous and calumnious stories which are maliciously propagated by the mercenary tools, vile prostitutes, and other deluded friends of the said Captain Green and his flagitious crew. . . E Edinburgh: printed by James Watson, in Craigs-Closs, on the North-side of the Cross. 1705 (ca. 7 May). $2^{\circ}$; 1-2 3-22 pp. (Roderick Mackenzie.) L, E, O

This tract was in direct response to one published in Edinburgh and London and purported to be the last speech and dying words of Captain Green (No. 185). That speech reflected so badly upon the government in Scotland that a response was inevitable. This pamphlet went through the phrases of The last speech to expose them as fakes and frauds manufactured in order to pillory the Scots as an unjust and bloodthirsty people.

415 Some few remarks upon the state of excise after the union, compar'd with what it now is. [1706]. $4^{\circ}$; $1-34$ blk. pp. (William Black.) L, E, LU-G, MH

Black, who was much more concerned with the Scottish economy than with the debate over the union as such, here again attempted to make sense of the malt/ale controversy and to refute assertions made against him by Defoe. The quarrel was over the amount of tax on malt and the increase which it would bring to the price of the ale drunk by the majority of the propulation of Scotland. Black pointed out that this and other interests of Scotland were not adequately protected by the treaty. Defoe was much morc interested in massing support for the union as such. This answered Defoe's No. 446, which had made reference to Black's earlier No. 408. Defoe answered this work in No. 447.

416 Some neutral considerations, with relation to two printed papers, which are cry'd about the streets, viz. The Committee of Parliament's report concerning the Indian and African Company, and an overture concerning the 
debts of the said Company. In a letter to a Member of Parliament. [1707]. $2^{\circ}$; 1-4 pp. (R.S.; Hanson, R. Seton). E

This tract on the equivalent examined the nature of that payment, its use, distribution, and reception in Scotland. The author maintained an air of impartiality and the entire pamphlet took on the appearance of a technical document. The cmphasis was upon the Company of Scotland and the distribution and use of funds paid to it.

417 Some overtures and cautions in relation to trade and taxes, humbly offered to the Parliament. By a well-wisher to his country. 1707 ( $\mathrm{E}$ ms. note, 14 January). $4^{\circ}$; 1-2 3-23 24 pp. (William Black.) E, LU-G, CtY, DFo, $\mathrm{MH}$

The author of this pamphlet could not be said to be against the union, but he did urge that the Parliament of Scotland make the most of the little leverage which it could exert upon England to gain as good terms as possible. The majority of the points raised were cconomic, and were concerned with: trade concessions, including such matters as encouragement of fishing; the salt duty; equal duties; freedom of trade to Ireland, and to the Indies; protection for the woolen industry; and adjustments of taxes. It was not an unreasonable tract, and many of the points were adopted on their own or were unnecessary after the union had been concluded.

418 Some queries humbly propos'd, upon the bill now depending before the Honourable House of Commons, for a toleration to the Episcopal dissenters in Scotland. [Edinburgh? 1712] (Moore, 29 January-26 February). $2^{\circ} ; 1-3$ 4 pp. (William Carstares; attributed by Moore to Daniel Defoe.) L, E, LU-G

[variant:] Some queries humbly propos'd upon the bill for a toleration to the Episcopal clergy of Scotland. [1712]. $12^{\circ}$; one side. E

The problems posed by having two distinct and opposing national churches, one in England and one in Scotland, and by having two distinct and non-established churches in those two kingdoms, were complex, and often impossible to reconcile. This tract first presented the general provisions to be granted to the Episcopalians in Scotland as the disestablished religion, and then questioned those provisions as they related to or undermined the established church as protected in the Act of Union. Finally it noted the rights given to the Episcopal dissenters in Presbyterian Scotland, but denied to Presbyterian dissenters in Anglican England. Other works in this debate include Nos. 60, 363, 413, and 91 .

419 Some queries proposed to consideration, relative to the union now intended. [Edinburgh? 1706] (Healey, before 2 November). $4^{\circ} ; 12-4$ pp. (John Bannatyne.) L, E, LU-G, DFo, InU, MH

The fourteen queries presented by the author purported to be merely questions for which answers were solicited, but the type of questions asked and the manner in which they were presented left little doubt that the author was against the union, and that he hoped to produce a similar response from others. This tract was answered by Nos. 31 and 138 . 
420 Some reasons humbly offered, why the English Oath of Abjuration should not be imposed upon the subjects of North-Britain, especially the ministers of the Gospel there. [Edinburgh? 1707/1708] (E ms. note: 14 February 1708 ). $4^{\circ} ; 12-8 \mathrm{pp}$. (Anonymous, although sometimes attributed to Robert Wodrow.) E, KU

[idem] Some reasons by a divine of the Kirk of Scotland, proving that their clergy there cannot with a safe conscience swear the English Oath of Abjuration. [London? $1707 / 1708$ ]. $4^{\circ}$; $1-8$ pp. L, E

This author did not feel that he could take the Oath of Abjuration in good conscience, not from any lack of loyalty to Anne, but rather because of the phrasing of the oath itself. In particular the author felt that the oath bound Presbyterians to support the Church of England and also bound them to denounce the exiled Stuarts, even though they might alter their religion to one acceptable to Scotland. Cf. No. 202.

421 Some remarks on a pamphlet, entituled, The Oath of Abjuration display'd in its sinful nature and tendency, \& $c$. Wherein the queries in that pamphlet are considered; and some counter-queries are offered to the author. ... Edinburgh, printed by John Moncur, at the foot of the Bull Closs. 1713 (E ms. note, $3 \mathrm{March}$ ). $4^{\circ}$; 1-2 3-52 pp.

E

The author of this pamphlet was writing to counter the more extreme reaction to the Oath of Abjuration of some within the Presbyterian Church in Scotland. In particular he wrote to refute the author of No. 269, who objected to the oath on religious grounds and who castigated those members of the civil and religious establishment who had taken it. The precise meaning of the oath and some extremely vague phrasing in the English manner gave the Presbyterians in Scotland amplc cause for alarm and ample reason for confusion. In tone, content, and wording, the onth offended many on the extreme edge of that church and also outside it; for Jacobites might refuse to swear as easily as extreme orthodox covenanters. This author was a moderate who sought to refute the more extreme Presbyterian objections and to calm hysteria. He also spent some time answering No. 270.

422 Some remarks upon Sir James Dalrymple's Historical collections. With an answer to the vindication of the ecclesiastical part of them. Where the ancient settlement of the Scots in Britain; their early conversion to Christianity; the government of their church by bishops; and some of their ecclesiastical rites and customs, are considered, and cleared from the mistakes of several learned authors.... Edinburgh, printed. Sold by George Stewart, at the Book and Angel. 1714. $8^{\circ}$; ( $i$ ii, errata) 1-162 pp. (John Gillan.) E, $\mathrm{O}, \mathrm{KU}$

This author examined the early history of the Church in Scotland and in particular the question of the existence of bishops in that early church. For the Episcopalians in Scotland it was most important that episcopacy be the ancient structure and presbytery the more recent innovation. Hence, Gillan sought to refute Dalrymple, who had asserted that episcopacy within the Church of Scotland was a more recent thing. The sequence of the controversy was: Nos. $362,235,482,236,156,450,35,188,160,81,451,483,238$, $519,422$. 
423

Some thoughts concerning the peace, and the thanksgiving appointed by authority to be observed for it. In a letter from an elder to a minister of the Church of Scotland. ... . [London] Printed for Robert Aldsworth near the Change. 1713. $8^{\circ}$; 1-2 3-31 32 pp. (George RidpatH.) E, KU

$\mathrm{L}, \mathrm{E}, \mathrm{O}, \mathrm{CtY}, \mathrm{DFo}, \mathrm{InU}, \mathrm{MH}$

$$
\text { . np. } 1713 \text { (L ms. note, "31 March (Peace); } 7 \text { July (Thanks)"). }
$$

[variant: ] . . thanks-giving, appointed . . e elder, to a minister. . . np. 1713. $4^{\circ} ; 1-34-24 \mathrm{pp}$.

The Anglo-French peace of 1713 did not please the whigs, and the writer of this tract was not reluctant to present arguments against it and the ministry. While predominantly an anti-tory tract, this pamphlet discussed Scotland as a part of that larger project. The author asserted that Jacobites were appointed to positions there, that oaths had been imposed upon the Scots to sow discord among them, that the established church was threatened by Episcopacy and Popery, that unconstitutional taxes had been imposed, and that Scottish trade had been sacrificed to France.

424 Some thoughts, on ways and means for making this nation a gainer in foreign commerce; and for supplying its present scarcity of money. . . . Edinburgh: printed by James Watson, in Craig's-Closs: sold by John Vallange, on the North-side of the street, above the Cross. $1705.8^{\circ} ; 1-23-70 \mathrm{pp}$. (William Seton.) L, E, LU-G, CtY, DFo, InU, MH

In 1705 and 1706 Scotland was much concerned with her economic development. This author began with the assertion that Scotland had not profited as much as she should have from her trade and industry over the past century. While some of this was due to English misgoverment and malice, more of it was due to inactivity and lack of protection within Scotland. Along with the creation of a judicature, he recommended the promoting of fishing, wool and cloth production, and other trading activities. It was a well-developed and interesting pamphlet, written in part to encourage the growth of a strong Scotland able to deal with England on more equal terms.

425 Some very weighty and seasonable considerations tending to dispose, excite and qualify the nation, for the more effectual treating with England in relation to an union of confederacy, as the nearest and most proper expedient to put the nation in a way of prosperitie and thriveing.... [Edinburgh?]. 1703 (after 2 November). $4^{\circ}$; 1-5 6-16 pp. (ANDREw Brown.) E, LU-G, MH

This author held that union with England-either federal or incorporating-was preferable to separation, which was the last resort. Given the poverty of Scotland, however, England could not be brought to such an incorporating union-which was the preferred type-without great exertion on the part of Scotland to demonstrate and to increase its worth. Reformation was to be sought in all spheres, but particularly in matters of economics where trade and industry-once placed on the correct road-would slowly prove the nation's worth and good intentions. It was a paper which emphasized Scotland's inadequacy, while at the same time urging it to make the most of its potential. 
of an union with England By a letter from the country to his friend in Parliament. [1705] (summer). $12^{\circ}$; both sides. E

The author of this tract was not at all certain that a further union with England would do any more for Scotland than had the union of the two kingdoms, which in the opinion of this author had been a disaster for church and state. Rather, he felt that giving up the remainder of her sovereignty would not be worth the trade concessions which Scotland might gain. He felt that Scotland was not so poor that she should go begging to England, but should attend to her own improvement.

427 The sovereign preservative of the health and life of the royal family, nobility, gentry, and people. By a gentleman of quality of North-Britain. In twelve volumes. Vol. I. The view of the ingredients of the universal antidote. With some observations on the hospitals in London. . . . London: printed for M. Wotton, at the Three Daggers in Fleetstreet, and sold by J. Morphew near Stationer's-Hall. $1708.8^{\circ} ; 1-23-16$ pp. L

Union produced many great, as well as small, problems, and this pamphlet dealt with one of the morc unusual of the lattcr--the differences in law and in practice in England and in Scotland for the surgeon, the physician, and the apothecary. This author, writing from a Scottish vantage point, tended to view the (to his way of thinking) uncontrolled situation in England with suspicion and horror.

428 A speech concerning a treaty of union with England. [Edinburgh. 1705] (July-August). $2^{\circ} ; 1-4$ pp.

E

The speech was relative to the debates in the Parliament of Scotland in the summer of 1705 over treating with England for a union of the two kingdoms. The author was much offended at the Alien and other acts against Scotland, and urged that Scotland should do nothing about union until England showed herself more willing to treat with Scotland as an cqual. England's good faith was questioned; indeed, the author thought the whole affair was nothing but a plot against Scotland. Finally his own preference for a federal as opposed to an incorporating union was but another caveat which he wished inserted in to the debate.

Speech, for which Sir Alexander Bruce was expelled. SEE: No. 435.

429 A speech in Parliament, by the Lord Belhaven; upon the Act for Security of the Kingdom, in case of the Queens death. Edinburgh, printed by the heirs and successors of Andrew Anderson, printer to the Queens most Excellent Majesty. 1703. $4^{\circ}$; 1-3 4-15 16 pp. (John HamiLton.) L, E, $\mathrm{CtY}, \mathrm{DFo}, \mathrm{InU}$

Lord Belhaven's speech was delivered in early June, 1703, and this tract undoubtedly followed soon thereafter. It was a bitter assessment of Anglo-Scottish relations since 1603, filled with recriminations and with arguments proving that Scotland had declined in every aspect since then. Belhaven argued that the union, the royal prerogative, and the state of bishops were three weapons used by England to keep Scotland dependent and poor. 
burgh?]. 1704 (dated 22 August). 4; $12-8$ pp. (E.C.; Grorge Mackenzie, Earl of Cromarty.) $\mathrm{E}$

The question of the exportation of wool versus the exportation of woolen cloth concerned many during the first part of the cighteenth century. In this tract Cromarty, who claimed to have no financial interest in either export, argued that the export of wool cloth would be a more beneficial sale to Scotland and its people than the export of raw wool, which was of morc benefit to the manufacturer abroad than to the Scots at home. It was an appeal for patience and for support for the wool industry, which still was not expanding as much as the Scots would have liked.

431 A speech in Parliament on the 10. day of January 1701, by the Lord Belhaven, on the affair of the Indian and African Company, and its colony of Caledonia. Edinburgh. 1701. 4 ; 1-2 3-12 Pp. (John Hamilton.) L, E, LU-G, DFo, InU, MH

Lord Belhaven spoke for many in Scotland in January 1701, when he detailed England's attacks upon Scotland's independence and sovereignty. The collapse of the Company of Scotland was a bitter pill, and that collapse was felt in part to be due to English hostility. Bethaven first related the advantages of trade in general, and then recounted the trials of the Company of Scotland at the hands of the English. He concluded with an appeal to the Scots in Parliament to proclaim to England their resentment of English encroachments upon Scottish independence and sovereignty, and Scotland's determination never to renounce her clains to Darien. It was a patriotic speech, and one which was well received.

432 A speech in Parliament the second day of November 1706. By William Seton of Pitmedden Junior, on the first article of the Treaty of Union. ... [Edinburgh]. 1706. $4^{\circ}$; 1-2 3-12 pp. William Seton. L, E, LU-G, MH, KU

[variant:] ... November, 1706. On the first article of the Treaty of Union... . Printed at Edinburgh; and re-printed at London, for Andrew Bell at the CrossKeys and Bible in Cornhill. 1706 (ca. 21 November). $8^{\circ} ; 12-8$ pp. O, InU

[same as London edition] Printed at Edinborough; and re-printed in Dublin, for M. Gun in Essex-Street. 1706. $8^{\circ} ; 12-8$ pp. CtY

In this speech Seton, who had been a commissioner, persuasively argued for the incorporating union proposed by the commissioners. He rejected separation as well as a federal union as either not in Scotiand's best interest or as unacceptable to England, and attempted to show that the proposed union would adequately protect Scotland's institutions.

433 A speech in Parliament touching limitations. [Edinburgh? 1703]. $4^{\circ} ; 1-8$ pp. (JoHn Hamilton; although E attributes to Andrew Fletcher.) E, $\mathrm{O}$

This tract, which probably was a part of the controversy over limitations on the monarchy in June and July, 1703, argued that the monarch of England and Scotland was so limited by the great power of the English Parliament that he or she was unable to act in either 
nation without concessions to it. If the Scottish Parliament were more powerful and if the King in Scotland were more limited, then the English Parliament would be less able to dominate either the monarch or the Scots. In short, if the King were more limited in Scotland, he would be more powerful overall. Cf. No. 404.

434 A speech in season against the union, or a smoaking furnace and a burning lamp, and for the lands rights with an advice in end to turn to the Lord, and recover his rights that hath been rendered up; and Scotlands cause of lamentation.... [Edinburgh? 1706?]. 4 ${ }^{\circ} ; 12-10$ pp. (Anonymous, although often attributed to Francis Grant.)

$\mathrm{E}$

This rather vicious attack upon the union attempted to bring to the attention of the Scots all of the disastrous and unpleasant consequences of the articles of the Treaty of Union. The intent was to arouse the Scots, and every possible insult toward the Scots was attributed to the English. In matters of religion, the Scots should regard themselves as abandoned and alone, sinful and united with those even more sinful. It would seem a most unlikely tract for Francis Grant to have written, for it reflected neither his style nor his way of thinking.

435 A speech in the Parliament of Scotland, in relation to Presbyterian government. [1702] ( $H W L$, July). $4^{\circ} ; 1-4$ pp. (Sir Alexander Bruce.) $\mathrm{L}, \mathrm{E}, \mathrm{CtY}$

[idem] Speech, for which Sir Alexander Bruce was expelled from being a Member of Parliament, in the year 1702, as the samen is insert in a book, entituled, The compleat history of Europe, or, a view of the affairs thereof, \&c. [1702]. $12^{\circ}$; both sides.

E

Alexander Bruce, an ardent Episcopalian, in this speech in the Scottish Parliament questioned the establishment of Presbyterianism as the Church of Scotland. He argued that it was not for certain the majority religion, and reflected on the way in which the ejected Episcopalian ministers had been treated. His remarks upon the character of the Presby. terians could not fail to arouse the anger of those of that religion in Parliament.

Speech in the Parliament of Scotland upon the union. SEE: No. 260.

436 A speech intended to have been spoken in Parliament by a Member who was necessarily absent. [Edinburgh. 1705]. $4^{\circ} ; 1-8$ pp. E, LU-G, $\mathrm{MH}$

This tract apparently was written to influence Members of the Parliament of Scotland during the first two weeks of July, 1705, when the union and rclated questions were being debated. The author, who supported a full union, urged that all legislation which would linat the monarch, restrict the succession, or stipulate trade concessions was unnecessary before negotiations, and also was likely to be counter-productive. Rather, the Parliament should enact a commission for a treaty, and delay almost all other matters until its next session.

437 A speech of one of the Barons of the shire of B- [Berwick] at a meeting of the Barons and Freeholders of that shire, for choosing commission- 
ers to represent them in the ensuing Parliament, summoned to conveen at Edil1burgh the 12th day of November 1702. [Edinburgh? 1702]. $4^{\circ} ; 1-23-78 \mathrm{pp}$. (John Sportiswoode.) L, E, MH

While urging a strong and firm union, Spottiswoode did not hesitate to suggest a possible Jacobitc prince in Scotland as an alternative to a Hanoverian succession in England. For him, the best solution would have been a Protestant Stuart in the direct line of succession, and this he urged on the electorate.

438 A speech without doors anent the giving a subsidy before the passing an Act of Security, \&c. ... 1704. $4^{\circ} ; 1-78-10$ blk. pp. InU

The mood of some in the Parliament of Scotland in 1703-1704 was belligerent and suspicious of all things English. This author argued that no moneys should be voted to the Qucen until she had approved such regulations and limitations as would secure the independency of the Crown and the honor of the country from bribes, pensions-and the English. It was an unusually forthright approach to the problem of the English influence in Scotland.

439 A speech without doors concerning exportation of wool. [Edinburgh?]. 1704. $4^{\circ} ; 1-23-8$ pp. E, LU-G, MH

As a kingdom with limited manufacture and with large amounts of raw materials usually available for export, Scotland had to reconcile its need to export wool with its need to encourage the native manufacture of cloth. The balance since 1700 argued for the encouragement of manufacture and for a ban on export, but the opposition was not satisfied. This tract examined this problem, and came down strongly for the manufacture of cloch in Scotland.

440 A speech without doors, concerning toleration. [Edinburgh? 1703]. $4^{\circ} ; 1-8 \mathrm{pp}$. (Roser' Wyllie; sometimes incorrectly attributed to Andrew Fletcher.) L

$$
\text { - [1703]. } 2^{\circ} ; 1-4 \text { pp. E, InU }
$$

InU

With an Anglican England sitting on the doorstep, the Presbyterian Scots could not help but pay attention to demands for a rcligious toleration for the Episcopalians there. This author rejected that plea on the grounds that the Episcopalians neither needed nor deserved such a toleration, and that efforts to give such a toleration were disruptive to the established church and state, and likely to promote the interests of the Papists and prelatists. It was an intolerant speech which allowed little room for argument.

441 Speeches, by a Member of Parliament, which began at Edinburgh the 6 th of May 1703. Edinburgh (Macfie, George Mosman?). 1703. $8^{\circ}$; 1-2 3-95 96 blk. pp. (ANDREw Fletcher.) E, O, CtY, DFo, InU, MH, KU 1703. $8^{\circ} ; 1-23-7879-80$ pp. E, DFo, MH 
Andrew Fletcher was one of the most determined advocates of an independent Scotland, and one of the men most often remembered in any discussion of the union and debates on that issue. This collection of speeches reflected the variety of problems faced in the Scottish Parliament in the spring and summer of 1703-the succession, limitations, the Protestant religion, and trade-and presented Fletcher's views on them.

442 The speeches made in the Parliament of Scotland, which met the 6th of this instant July, 1704. in relation to the settlement of the succession of that kingdom in the Hanover line. London printed, and sold by B. Bragg in Avemary-Lane. $1704.2^{\circ} ; 1-4$ pp. L

In 1704 the Parliament of Scotland was greatly concerned with the question of the succession, and these speeches were a part of that debate. The Scots feared that to settle the question in favor of the Hanoverians would encourage the English to take them for granted. These speeches, however, urged that the succession be settied in the House of Hanover as an alternative to the French-based Pretender.

443 A state of Mr. Paterson's claim upon the equivalent; with original papers and observations relating thereto. London. 1712 (dated 21 February 1711/12). $4^{\circ}$; 1-89-11 12 1-72 pp. O, LU-G, CtY, DFo, MH

The majority of the petitions presented to various bodies in behalf of Paterson have not been included in this checklist, but this tract contained so much material relative to the Company of Scotland that it merited inclusion.

444 The state of Scotland, under the past and present administration. With relation to England, \&c. 1703. $4^{\circ} ; 1-23-24 \mathrm{pp.}$ InU

[variant:] The stae (!) of Scotland.... 1703. $4^{\circ} ; 1-23-24$ pp. $\quad$ E, O, CtY, DFo

Scottish politics in the time of Anne were complicated, and at no time more so than during the first years of her reign. This extremely partisan analysis of politics, parties, and Parliament in 1702-1703 sought to persuade the Qucen to pursue policies there which would be anti-Presbyterian and anti-whig; the Presbyterians were held to be a small element which, although powerful, was forever against monarchy. The Queen's friends (or cavaliers) should be brought in and given office to do as she, not a faction or party, wished. Unfortunately, the pamphlet was as confused and as confusing as the politics of the day.

445 State of the controversy betwixt united and separate Parliaments. Whether these interests which are to be united by the present treaty, and these interests which by the same treaty are to remain separate and distinct. Are more properly and safely lodged under the guardianship of an united Parliament, or under that of separate Parliaments. 1706 (Mathieson, written, if not published, before 19 September). $4^{\circ} ; 1-23-28$ pp. (Andrew Fletcher.) L, E

$$
\text { 1706. } 4^{\circ} ; 1-23-2324 \text { blk. pp. L, E, LU-G, InU }
$$

This pamphlet was written after the commissioners had treated in London and before 
the Parliament of Scotland had met to consider the articles which the author had before him. It was a pamphlet which urged a federal as opposed to an incorporating union. The latter was held to be ruinous for the religious, political, and economic well-being of Scotland, while the former would enable Scottish interests to be protected in Edinburgh by a separate Parliament. It was a well-written pamphlet, presenting views which were not without merit, but which ultimately were not accepted. This was answered by No. 121.

446 The state of the excise after the union, compared with what it is now. [Edinburgh]. 1706 (Moore, ca. 1 December). $4^{\circ}$; 1-2 3-8 pp. (Daniel Defoe.) L, E, LU-G, CtY, MH, KU

In the autumn and winter of $1706 / 7$ the Scots were much disturbed by rumors of an increase in the tax on malt after the union which would mean a doubling of the price of ale. It was the sort of rumor which would stir a massive public protest, and this author sought to refute the rumor and to show that taxes would not increase. The problem it: part was due to differences in the way in which ale was made and bottled in Scotland an... England; but as a popular issue it was guaranteed to arouse a protest, however false rumor. This tract of Defoe's only entered his larger debate with Black in that it made passing reference to No. 408. It was answered by Black in No. 415; Defoe responded with No. 447.

447 The state of the excise \&c. Vindicated, from the remarks of the author of the Short Vicw, \&c. Wherein some other escapes of that author, are likewise taken notice of. [Edinburgh. 1706]. $4^{\circ} ; 12-8$ pp. (DanIEL DefoE.) E, LU-G, CtY

This tract concluded the long and often confusing debate over the cost of ale after the union. The debate in great part merely reflected confusion on the part of those debating over the various duties to be paid. They all disagreed as to the price per unit and figured various items in calculating that price differently. Defoe sought to conclude a complete investigation of the matter, and to lay to rest claims that the price of ale, a most popular drink, would double. This was Defoe's answer to Black's No. 415, which in turn had answered No. 446. This pamphlet also referred back to Black's earlier No. 408.

448 The state of the nation enquir'd into, shewing the necessity of laying hold of the present opportunity, to secure our laws and liberties, from English influence; and procure a free trade with that nation. [Edinburgh. 1705/1706]. $4^{\circ}$; $12-16$ pp. (Archibald Sinclair.) E, LU-G, CtY, DFo

This writcr-like so many Scots of his day-concluded that Scotland had not only declined in relation to what it once had been, but also in relation to England. This decline was due to monarchs who had abused her in the past, to Parliaments which were too corrupt and venal to stand up for Scotland, and by ministers who did not work for the best interests of Scotland. This deplorable state of affairs, however, could yet be remedied not so much by union as by internal rejuvenation and by a true devotion to the better impulses of all Scots.

449 Strange news from Scotland, or, Scotch Presbyterian piety evidently prov'd by the regard they shew to consecrated churches, the bodies of the dead, 
\&c. A late instance whereof, may bc seen, at this day, at Dunglass, belonging to Sir James Hall, Bart. near Cockburn's-Path, fourteen miles to the northward of Berwick upon Tweed, in Scotland.... [London] Sold by J. Morphew near Stationers-Hall. 1712 (ca. 22 January). $8^{\circ} ; 1-23-1516$ pp. L, E, O, DFo, InU

Written in the middle of the controversy over the Oath of Abjuration in early 1712, this tract purported to be the account of an English, and presumably Anglican, traveler in Scotland. There he witnessed the desecration of an Episcopal church by a gentleman who had turned it into a stable. Every emotional chord was touched in this horrified depiction of the plight of the Episcopalians in Scotland.

450 The superiority and direct dominion of the imperial crown of England, over the crown and kingdom of Scotland, and the divine right of succession to both crowns inseparable from the civil, asserted. In answer to Sir Thomas Craig's treatises of homage and succession. Occasionally detecting several material errors, of Sir George Mackenzie, and other eminent authors. With some account of the antiquity, extent, and constitution of the now English monarchy. Explaining considerable parts of the British, English, and Scotch histories and laws.... London, printed for J. Hartley, next door to the King's-Head Tavern in Holbourn. 1704. $8^{\circ}$; (i-xvi xvii blk. xviii, errata) 1.576 $577-578$ blk. pp. (William Atwood.) L, E, O, LU-G, CtY, DFo, InU, $\mathrm{MH}$

The refusal of the Scots to follow the lead of England and to settle the succession on the Hanoverians posed the possibility of two sovereign kingdoms on the island. Atwood apparently was dismayed at this thought. He wrote this to prove that Scotland was not independent of the imperial crown of England, and that it could not-and to do him justice, in his opinion should not attempt to-be independent. This work was burned by the common hangman in Scotland, but the damage already was donc. The sequence of the debate was: Nos. $362,235,482,236,156,450,35,188,160,81,451,483,238,519,422$.

451 The superiority and direct dominion of the imperial crown of England over the crown and kingdom of Scotland, the true foundation of a compleat union, reasserted. By William Atwood, esq; In animadversions upon a scurrilous pretended answer to him; for which the Parliament of Scotland have given 4800 Scotch punds. With incidental remarks on Sir James Dalrymple's Collections concerning the Scotish history: and on a late pamphlet, entitled, The memorial of the state of England.... London: printed and are to be sold by John Nutt, near Stationers-Hall. 1705. $4^{\circ}$; (I-IV) i-xii 1-106 107-108, advt. pp. William Atwood, L, E, O, InU, MH

Atwood felt that his first effort at proving the dependency of Scotland upon the imperial crown of England had been unjustly treated, and he therefore wrote this refutation in an attempt to vindicate his ideas and to place such men as Ridpath, Anderson, Sibbald, and Dalrymple in perspective. He sought to examine the major points made against him one by one and to disprove them, but the intrusion of contemporary matters forced him to 
deal as well in labels current in his society. The sequence of the debate was: Nos. 362, $235,482,236,156,450,35,188,160,81,451,483,238,519,422$.

A supplement on occasion of the new Scotch Presbyterian Covenant. SEE: No. 264.

452 The testamentary duty of the Parliament of Scotland, with a view to the Treaty of Union now on foot, and considerably advanced betwixt the two kingdoms. ... [Edinburgh?]. 1707 (early January). 4 ; $1-23-1718 \mathrm{pp}$. (Thomas Spence.) L, E, LU-G, CtY, MH, KU

Writing as the Parliament of Scotland debated the articles in the last months of 1706 and the first weeks of 1707 , the author attempted to draw the attention of the Parliament to constitutional and legal problems still unresolved. In particular, he was concerned with the state of Scottish law, the appointment of judges and other civil servants, appeals in Scottish law, and the Scottish Privy Council. The last pages were written just as the nineteenth article passed, and reflect a growing anxiety that in the haste of ratification, serious flaws in the articles would not be corrected.

453 A thanksgiving-sermon, occasioned by the union of England and Scotland, preach'd at Hand-Alley, May the 1st, 1707. London, printed by J. Humfreys, for John Lawrence at the Angel in the Poultry. [1707]. $8^{\circ} ; 1-2$ 3-16 pp. Daniel Williams. L, E, O, InU

This sermon by the dean of the Presbyterian ministers of London praised union as the work of God and of Anne, and as of positive benefit to all concerned. In its political, constitutional, and legal arguments, it surpassed the vast majority of such sermons, which tended to be laudatory and to avoid any issue of controversy.

454 A thanksgiving sermon preach'd on the first day of May, 1707. On occasion of the happy union between England and Scotland. London; printed by J. Darby, and sold by J. Baker at Mercer's-Chappel in Cheapside. 1707. $8^{\circ}$; 1-2 3-16 pp. Giles Denr. L, O

This moderate sermon attempted to rally support for Anne and her policy toward the union. Dent recognized that the union provoked mixed feelings, and agreed that such unions never were perfect from any angle. Himself a strong whig and supporter of William III and the revolution of 1688 , he nevertheless sought to avoid controversy.

A thanksgiving-sermon, preach'd on the first day of May, 1707. On occasion of the happy union between England and Scotland. . . London, printed for John Lawrence at the Angel in the Poultrey. 1707. $4^{\circ} ; 1-23-23$ 24 pp. Christopher Taylor. L, E, O

This Presbyterian minister was most concerned with divisions within Scotland between Episcopalians and Presbyterians, and his sermon, while praising Anne, tried to avoid anything which might further divide Scotland or antagonize the Anglicans in England. Taylor was anti-Papist, anti-French, anti-James II, and very much pro-William. 
456

That part of a late book which relates to a general fast and humiliation. Printed a part. Nota. That the book it self entituled; the Rights and interests of the two British monarchies, with a special respect to an united or separate state Treatise III. Containing farther enquiries into the best means for procuring a happy union betwixt the two kingdoms ... consisting of 18 sheets, is sold at Mrs. Ogston's shop in the Parliament-Closs. [Edinburgh? 1703]. $4^{\circ}$; $1-1516$ blk. pp. (James Hodges.) E

This is a reprinting of pp. 120-139 of Hodgcs' No. 341. It was done to counter the false impression made by the reprinting, with deletions and alterations, of this same set of pages in No. 133. The impact of this tract was that an incorporating union would confuse the respective interests of Scotland and England and would lead to disaster.

457 Three essays. I. Essay on the new project for a land mint, \&c. 2. A second essay concerning the land mint. 3. A scheme proposing a truc touchstone, for the due trial of a proper union betwixt Scotland and England, \&ac. By the author of the Character of the true publick spirit. Edinburgh. 1706. $8^{\circ}$; (i-xiv) 1-31 32-35 36 blk. (i-xxiv) 1-39 40 blk. (i-xviii) 1-34 pp. (ANDREw BRown.) $\mathrm{E}$

This author was more concerned with matters of economics than of politics, and the first two essays of the threc in this collection were concerned with the problem of coinage and banking in Scotland. The shorlage of capital and the inadequate banking system were well-known and attracted considerable interest. The third essay dealt directly with the union, but did so not with reference to the actual treaty or its articles, but in general terms and with an attempt to impose a set of standards by which a union might be judged. Those standards were to be viewed from the Scottish stance. The three essays were printed separately as Nos. 123,376 , and 345 .

458 A three-fold cord for ensuring and securing of Presbytry in Scotland. The first. Her Majesty's repeated promises and engagements in favours thereof. The second. Our laws and acts of Parliament, especially these near fifteen years bygone. The third. Our national claim of right, and the people their fixed resolution to stand by it ... In a letter from a true lover of the Protestant religion, his Qucen and countrey, unto the Members of this present Parliament. [1704]. $2^{\circ} ; 1-4 \mathrm{pp}$.

E

In most respects this paper was more of an internal Scottish tract than one dealing with Anglo-Scottish relations. It does deal with the problem of Episcopacy as an "external" religion which the Presbyterians felt was being forced upon them by England; it was therefore "alien" and had no right to claim equality with the Church of Scotland. This tract was concerned with a restatement of the position of the Church of Scotland, and claimed that it should not and could not be disestablished. The repeated promises of the Queen, the laws and acts of the Scottish Parliament, and the allegiance of the people to it were a three-fold cord securing that church. 
the south and western shires. [Edinburgh. 1706]. (dated; Defoe, History, 12 November.) $1 / 2{ }^{\circ}$; both sides. L, E, DFo, KU

Opposition to the union between England and Scotland took several different forms. This address opposed the unior primarily on religious grounds, holding that the Scots could not bc expected to unite with such a godless people as the English, who had broken the covenant and had lived under prelacy. Outrage was evident in every line of this protest. John Hepburn, who subscribed it, was leader of one of the more extreme factions within the Church of Scotland (or outside it).

460 Ta Hir Gracc Her Majestics high Commissioner, an te Honorable Estates of Parlment; Te address far te fishers on te Highland coasts, an all uthers inhapiting te Highlands, wha it ma concern, humbly representing tat it will pe exceedingly disadvantageous to $\mathrm{Her}$ nane sel, tat te Articles of te Union concerning salt, and excise pe agreed to, without an mendment in case the union is concluded. (!). [Edinburgh. 1706]. $4^{\circ} ; 1-78$ blk.pp. E, O, LU-G, CtY

No issue proved more elusive nor more durable than that of the fisheries and the companion problem of the salt duties. The Scots used inferior domestic salt which was cheap and readily available; the articles and the union threatened that supply of salt and would alter the price considerably. This early tract pointed out the disastrous impact of such an article in the union and sought amendment of it to protect the fishing and allied industries. The use of "Scots" language was an interesting if somewhat artificial approach.

461 To His Grace Her Majesties High Commissioner and the Honourable Estates of Parliament. The heemble petition of the peer shank workers and fingren spinners of Aberdeen, and places, thereabout. [Aberdeen? 1706/1707]. $4^{\circ} ; 1-8 \mathrm{pp}$.

L

This was essentially an economic tract, written in "mock" Scots in favor of the union, and attempting to show how certain industries-wool in particular-would benefit from that union.

462 To His Grace her Majesties high Commissioner, and the Honourable the Estates of Parliament, the address of the barons, freeholders, heritors, and others of the 4 parishes of the Glenkenns; in the Stewartry of Kirkudbright, conveened at St. Johns Clauchan of Dalray, the 19th of November 1706 years; upon the great concern, of the union proposed and treated of in several articles betwixt Scotland and England. [1706]. $2^{\circ} ; 1-34$ blk. pp. E, DFo

The chorus of protests against the union included in the fall of 1706 one from Kirkcudbright. The arguments against the union had much in common with others sent to Edinburgh: Scotland would be subjected to higher taxes, she would lose her Parliament and liberty, and she would lose all security for the established church.

463 To His Grace, Her Majesties High Commissioner, and the Right Honourable Estates of Parliament, the humble address of the Presbytery of 
Dumblane. [Edinburgh. 1706] (Defoe History, 11 December). $1 / 2^{\circ}$; one side. L, E, DFo

The Presbytery of Dunblane was not slow to protest the union with an Anglican state in which the Anglican church would be allowed to function under securities built into the treaty. Dunblane at least was not convinced that conversion-by force if necessaryshould be abandoned.

464 To His Grace, Her Majesty's High Commissioner, and the Right Honourable Estates of Parliament. The humble representation and petition of the Court of Directors of the Indian and African Company. [Edinburgh? 1706] (dated 28 December). $1 / 2^{\circ}$; one side. O, DFo

This petition was in behalf of those London merchants who had invested in the Company of Scotland's ship, the Annandale. Their involvement in the Scottish company obviously was unacceptable to the English East India Company, which viewed the nearly defunct Scottish company as a cover for activities by those unable to trade in the highly monopolistic English Company. The seizure of the Annandale was an indication of that suspicion of the Scottish organization.

465 To His Grace, Her Majesty's High Commissioner, and the Right Honourable Estates of Parliament, The humble representation of the CouncilGeneral of the Company of Scotland trading to Africa and the Indies. [Edinburgh. 1706] (dated 27 November). $2^{\circ} ; 12$ blk. leaf, endorsed, verso pp.

$\mathrm{E}, \mathrm{O}, \mathrm{CtY}, \mathrm{DFo}$

The debts of the Scottish East India Company were to be paid out of the equivalent moneys, but that settlement was by no means acceptable to all who had invested in the company. This representation argued that the settlement was inadequate for losses sustained, that it did not include adequate interest payments, that the full debts were not guaranteed, that trade by the company had to be suspended before payment actually was made, and that there was no security for company goods or ships. Undoubtedly for those who thought all had been lost, the payment was more than encouraging, but not all saw it that way. Cf. No. 333.

466 To His Grace, Her Majesty's High Commissioner, and the Right Honourable, the Estates of Parliament, the address of the Commissioners to the General Convention of the Royal Burrows of this ancient kingdom, conveened the 29th of October last, upon the great concern of the union, proposed betwixt Scotland and England, for concerting such measures, as should bc esteemed proper for them to take, with relation to their trade, and other concerns. [Edinburgh. 1706] (between 29 October and 26 November, when rcprinted in the Review). $1 / 2^{\circ}$; one side. L, DFo

In 1706 considerable numbers of Scots werc disturbed to a greater or lesser degree by provisions in the proposed Treaty of Union. This petition protested the loss of Scotland's Parliament; the threat which that loss would pose to the established religion; and the insecurity of Scotland's trade, if protected only by an English-dominated British Parliament. 
467 To His Grace, Her Majestics High Commissioner, and the Right Honourable the Estates of Parliament, the address of the provost, bailies, towncouncill and burgesses of the burgh of Forfar. [1706] (presentation date; Defoe History, 9 November). $1 / 2^{\circ}$; one side. DFo

This petition from Forfar, presented by Mr. John Lyon, is a straightforward plea to the Parliament to reject the union.

468 To His Grace Her Majesties High Commissioncr and the Right Honourable the Estates of Parliament. The humble address of the barons, freeholders, heritors, and other gentlemen in the shire of Forfar. [1706] (presented, 2 November). $2^{\circ} ; 1-34$ blk. pp. DFo

This petition from the shire of Forfar carricd the signatures of a considerable number of gentlemen of the shire, but in all other particulars it was the same as the petitions from other boroughs in that geographic area, and urged the Parliament not to accept the union.

469 To His Grace, Her Majesties High Commissioner, and the Right Honourable the Estates of Parliament; the humble address of the magistrates, town council, burgesses and inhabitants of the burgh of New Galloway. [Edinburgh? 1706] (Defoe History; Bib. Linds., 3 December). $1 / 2^{\circ}$; one side. E, DFo

This is another in a series of petitions to the Parliament of Scotland opposing the union. Honourable the Estates of Parliament, the petition of the merchants of Edinburgh, for themselves and in name and behalf of the other merchants and traders within this kingdom. [1705?]. $12^{\circ}$; one side. ESR

A petition in form and purpose, this single sheet illustrated the difficulties facing Scots merchants and traders who were attempting to pursue a separate interest from the London and English merchants in times of war. The Scots were thought to be trading with France and their ships werc seized by the English. According to the Scots, injustice was done to them both in the courts and outside them. Commissioner, and the Right Honourable Estates of Parliament. The petition of the Court of Directors of the Company of Scotland, Trading to Africa and the Indies. [1704] (dated 11 August). $2^{\circ} ; 12-4$ pp. E, O

This petition to the High Commissioner and to the Parliament in Scotland protested the seizure of the Annandale by the English East India Company as it had set sail to take on the goods of the Speedwell, which had been lost except for its cargo. The Company of Scotland protested this and other acts of an illegal or violent nature which had been suffered by the company since its inception. 
missioner; and to the Right Honourable, the Estates of Parliament: The humble address and petition of the Commission of the General Assembly of the Church of Scotland. [Edinburgh? 1706]. $12^{\circ}$; one side. DFo

This petition sought to protect the Church of Scotland from all possible harm, and to ensure its position under the articles then being debated.

473 To the King's Most Excellent Majesty, (James VII.) The humble address of the citizens and inhabitants that are of the Presbyterian perswasion in the city of Edinburgh and Canongate. Edinburgh, printed ... from the copy, printed by the heir of Andrew Anderson, printer to His most Sacred Majesty, City and Colledge, 1687. 1703 (7 June). $12^{\circ}$; both sides. RPBJCB

The "Some few remarks" added to this reprinted address of 1687 bitterly reminded the Presbyterians of their subservience to the monarch in 1687, and accused them of opportunism, insincerity, and a general lack of principle in matters other than the advancing of their religion.

474 To the loyal and religious hearts in Parliament, some few effects of the union, proposed between Scotland and England. Except God prevent will fall out. [1706] (E ms. note, 9 November). $1 / 2^{\circ}$; one side.

E

Opposition to the union did not lack adherents or causes in 1706. This author was content to list the objections as follows: the loss of sovereignty, laws, Parliament, liberties, independence, true religion, trade and industry, and identity; the imposition of prelacy and idolatry; and the military occupation of Scotland. It was a list calculated to arouse emotions among those opposed to the union.

475 To the ministers and elders met at Edinburgh, April 26, 1710. The just complaint and remonstrance of the National Covenant of Scotland, and the Solemn League and Covenant of the three kingdoms of Scotland, England, and Ireland. [Edinburgh. 1710]. $8^{\circ} ; 12-8$ pp. L, O

This poem in praise of God and the covenant, and in condemnation of those who abindoned that God and covenant, abounded with admonitions, encouragement to reformation, and other religious charges and pleas. It was a good example of the more extreme element at work within the Presbyterian church in 1710.

476 To the Most Honourable the Pecrs of Great Britain, in Parliament assembled. The humble representation of William Carstares, Thomas Blackwell and Robcrt Baillie, ministers of the Church of Scotland, offer'd by them in the name, and by the appointment of the Commission of the late General Assembly of the aforesaid church, concerning the bill for restoring patronages now depending before Your Lordships. [1712] (Kennett, 4 April). $12^{\circ}$; one side. $\mathrm{E}$

The bill to restore patronage in Scotland could not help but offend the Presbyterians there, 
and this was a part of that belated protest against a bill passed by the torics to appease the high church element in the Parliament of Britain. The authors attempted through religious, historical, and other arguments to block the bill, but it was in vain.

477

To the Queen's Most Excellent Majestie, the humble address and supplication of the suffering Episcopal clergy in the kingdom of Scotland, whose names and designations are underwritten. [Edinburgh. 1703] ("This address was presented to the Queen, March 13th. 1703"). $12^{\circ}$; both sides. $\mathrm{E}, \mathrm{O}$

[variant:] (Lacking inscription). $\mathrm{E}$

$$
\text { [Edinburgh? 1703]. 1/2 }{ }^{\circ} \text {; one side. E, O }
$$

This plea to the Queen for assistance was part of the larger attempt during the reign of Anne to resolve the problem of: the Episcopal clergy of Scotland who had heen expelled from their churches in 1688 and thereafter. Their financial plight was a hard one, and appeals both in and out of Scotland carried considerable emotional weight.

478 To the Queens Most Excellent Majesty, the most humble representation and petition of the Commission of the late General Assembly of the Church of Scotland. [Edinburgh]. 1712 (dated Thursday, 14 February). $1 / 2^{\circ}$; 12 pp. L, E

The attempt to secure a toleration for the Episcopal clergy in Scotland met with resistance from the Presbyterian clergy there. The arguments used in this response to a bill entitled "A bill to prevent the disturbing those of the Episcopal communion in Scotland . .." werc fairly routine, and included the charges that such a toleration would be dangerous to the church and state.

479 [copy mutilated] . . the Right Honourable the Estates of Parliament. The humble address of the magistrates, town-council, merchants, deacons of crafts, and others trades men and inhabitants of the burgh of Dunfermling. [1706] (Defoe History, read 8 November). $12^{\circ}$; one side.

This was one of the petitions of late 1706 against the union. It was from a rather unusual assortment of artisans-fleshers, baxters, smiths, wrights, and weavers--as well as merchants. They opposed the union on the usual political and religious grounds.

480 To the Right Honourable the Lords of Council and Session, the petition of Mr. James Greenshields Minister of the Gospel. [Edinburgh? 1709] (ca. 12-19 November). $2^{\circ} ; 12-7$ pp. James Greenshields. L, E (lacking pp. 5-7), $\mathrm{O}$

This petition by Greenshields, an Episcopal minister, sought his release from the Tolbooth in Edinburgh, where he had been imprisoned for some ten weeks for conducting services in Edinburgh according to the Episcopal rites. His case, which was to become one of the most famous of the reign of Anne, was still in its early stages when this petition appeared. The Lords of Council and Session had refused his bill of suspension on the grounds that 
he was a minister, and Greenshields attempted to defend his ordination and to restate his casc.

481 To the Right Honourable, the Lords of Her Majesty's Privy Council, the Directors of the late Company of Scotland, trading to Africa and the Indies. For themselves and others concerned with them, in the ships and adventures after-mentioned. [Edinburgh. 1707]. $1 / 2{ }^{\circ} ; 12 \mathrm{pp}$.

$\mathrm{E}$

The plight of the Annandale, seized near London, haunted Anglo-Scotish relations throughout the reign of Anne. It was the scizure of the Annandale which had prompted the seizure by the Scots of the Worcester, with all that was in turn provoked. This petition for redress is more legal than polemical, but is included to complete the materials on Green and the Company of Scotland.

482 To the Right Reverend the Ld. Bishop of Carlisle. Containing an historical deduction of the alliances between France and Scotland. Whereby the pretended Old League with Charlemagne, is disproved: and the true Old League is produced and asserted. To which is added, a notable piece of churchhistory from Her Majesty's archives; never before publish'd. Letter II. London: printed for Tho Hodgson, over-against Gray's-Inn Gate, in Holborn; and sold by J. Nutt near Stationer's-Hall. 1702 ( $H W L$, December). $8^{\circ}$; (i-ii) 1-101 102, advt. pp. (Thomas Rymer.) L, E, DFo, InU

The second letter from Rymer concerned itself not only with Robert III, but more importantly with the history of the alliances between Scotland and France (which Rymer denied dated from the time of Clarlemagne) and between Scotland and England. 'This question of the sovereignty of Scotland and the place it held in Europe was of great importance to the Scots who, in the reign of Anne, were confronted with assertions that Scotland was dependent upon England and always had been so. The sequence of the debate was: Nos. $362,235,482,236,156,450,35,188,160,81,451,483,238,519,422$.

483 To the Right Reverend the Ld. Bishop of Carlisle. Containing a third vindication of Edward the Third. Letter III. London: printed by W. Bowyer. $1706.8^{\circ}$; (i-ii) 1-14 pp. (Тномas Rymer.) E

Charges and counter-charges of brutality were common in this historical controversy, and in this letter Rymer vindicated Edward III from charges by the Scots that the monarch had threatened to kill the two sons of the Governor of Berwick unless he capitulated. Rymer had little trouble discounting the tales told by the Scottisl historians. The sequence of the controversy was: Nos. $362,235,482,236,156,450,35,188,160,81,451$, $483,238,519,422$.

484 The toleration gazette from August 1703, to March 1704. [Edinburgh? 1704]. $1 / 2^{\circ}$; both sides. E

This pseudo-newspaper attempted to discuss the prevailing mood of the various parts of Scotland to the question of a toleration for the Episcopalians. The author, a Presbyterian, was not seeking objectivity; but he was neither angry nor bitter in his tone, and the use of a newspaper format with stories from the various parts of Scotland was uncommon. 
485 A toleration in Scotland no breach of the union. London. 1712 (Kennett, between 21 and 30 January). $4^{\circ} ; 1-23-8$ pp. (Wildiam Strachan.) E

The question of a toleration for the Episcopalians in Scotland prompted much publication for and against this act. This writer strongly supported toleration on the grounds that it was warranted by history, religion, and the actions of the Episcopalians there. He denied that the majority of the populace were Presbyterians, and argued that in an open election they would lose badly. Arguments against a toleration-including a charge that it would be a violation of the Treaty of Union-were given no encouragement. It was a pamphiet calculated to appeal to the Anglican majority in England.

486 The trade of Britain stated; being the substance of two papers published in London on occasion of the importation of wine and brandy from North-Britain. [Edinburgh. 1707] (reprinted from the Review, 10 and 12 June). $4^{\circ} ; 1-8$ pp. (Daniel Defoe.) L

The "Draw-back Bill," along with other quasi-legal measures passed in the Commons to regulate the importation of cheaper wines and brandy from Scotland before 1 May 1707, provoked howls of outrage from Scots, who claimed that the Treaty of Union had been violated. Defoe sought to calm that rage and to explain to all concerned that both sides felt betrayed, but that the situation was far less scrious than those opposed to the union would have it seem.

487 The trade of Scotland with France, consider'd; in two letters directed to the author of the Mercator. Edinburgh: printed by James Watson. Sold at his shop opposite to the Lucken-booths. 1713 (published in the Mercator, 7 and 9 July, and republished thereafter). $4^{\circ} ; 1-23-8 \mathrm{pp}$. (Anonymous; attributed by Moore to Danicl Defoe.) E, LU-G, CtY, InU

The merits of trade between Scotland and France as opposed to Scotland and England received much attention during the reign of Anne. Many Scots felt that France was a more natural and beneficial trading partner than England. These two letters discussed those and other points relative to the French Commerce Bill and the consequences of its defeat upon Scotland. The author felt that its passage would have opened up markets for raw products which Scotland could have exported to France at a profit. In the last letter the argument was advanced that Scotland's interest had been sacrificed to that of England, who would gain less from the comnercial treaty, and that the bill's defeat had been due in part to the votes of Scots M.P.'s who had acted against Scotland's interest as well.

488 The tryal of Captain Thomas Green and his crew, pursued before the Judge of the High Court of Admiralty of Scotland; and the Assessors appointed by the Lords of Privy Council, at the instance of Mr. Alexander Higgins Advocat, Procurator-Fiscal to the said Court, for piracy, robbery, \& murder. Faithfully extracted from the records of the said Court, and other authentick documents. Published by authority. Edinburgh, printed by the heirs and successors of Andrew Anderson, printer to the Queens most Excellent Majesty. 1705. $2^{\circ}$; (i-v vi advt.) 1-65 66 blk. pp. E, CtY 
[idem] The tryal of Capt. Thomas Green and his crew, before the Judge of the High Court of Admiralty of Scotland; and the Assessors appointed by the Lords of Privy Council. At the instance of Mr. Alexander Higgins Advocate, Procurator-Fiscal to the said Court, for piracy, robbery, and murder. Faithfully extracted from the records of the said Court, and other authentick vouchers. Published by authority. Edinburgh, printed by the heirs of Andrew Anderson, printer to the Queen's most Excellent Majesty . . . And re-printed at London for Andrew Bell, at the Cross Keys and Bible in Cornhil; and Hugh Montgomery, at the Golden Anchor in Cornhill. 1705 (ca. 14 June). $2^{\circ}$; (i-v vi blk.) 1-1121 13-67 68 pp. L, E, O, DFo, InU, MH

The trial of Captain Green for piracy, murder, and robbery aroused great interest not only in Scotland, where he was charged with piracy, but also in England, where he was thought a victim of Scottish injustice. This account of the trial was more or less "official" in that it sought to present an account of the trial in a more or less objective fashion. Information which was given to the Scottish court was reprinted, admittedly in a proScottish fashion or in accord with Scottish legal customs. Most interesting were the marginal notes in the London edition, explaining Scottish legal procedures to the English audience, to which this edition was aimed.

489 Trialogus. A conference betwixt Mr. Con, Mr. Pro, and Mr. Indifferent, concerning the union. To be continued weekly. $1706.4^{\circ}$; (i-ii) 1-8 pp. (George Mackenzie, Earl. of Cromarty.) L, E, LU.G

... concerning the union. Second conversation. 1706 (ca. 14 June). $4^{\circ} ; 9-15$ 16 pp. E, LU-G

... concerning the union. Third conversation. $1706.4^{\circ} ; 17-22$ blk. leaf pp. E, MH

Trialogus. Fourth conversation. $1706.4^{\circ} ; 23-30$ pp. E

Trialogus. The seventh conversation on the 15 th article of the treaty. $1706.4^{\circ}$; 1-4 pp. E

This series of position papers or statements of opinion on issues in the union debate aimed at promoting that union through the presentation of three points of view. It was to be a conversation among three men relative to the union: one was objective, one for the union, and one against it. While purporting to be objective, the "indifferent" man tended to ask those questions which $\mathrm{Mr}$. Pro was most likely to be able to answer effectively. The author in short was for the union and used this technique to emphasize that attitude. This was answered in No. 215.

490

The trimmer: or, some necessary cautions, concerning the union of the kingdoms of Scotland and England; with an answer to some of the chief objections against an incorporating union.... Edinburgh. 1706 (Robert Mylne ms. note, 6 December). $4^{\circ}$; 1-2 3-16 pp. (John Sportiswoode.) L, E, LU-G, MH, KU

The author agreed that union was inevitable and that the alternatives to compromise 
were unacceptable and unattractive. Nevertheless he felt that there were inadequate safeguards for Scotland's religious, legal, and economic intercsts, and he feared that the Scots would not be granted equal access to offices and positions. This pamphlet reflected the second stage of Scottish controversy; having accepted the reality of a union, the argument moved to the type and form of that union and the degree to which the articles as proposed met cxisting problems.

491 A trip lately to Scotland. With a true character of the country and people: also reflections on their proceedings to disturb the present reign: to which are added several remarks, on the late barbarous execution of Capt. Green, Mr. Madder, Mr. Simpson, and several others. With an elegy of their (unmerited) deaths. London, printed, and sold by S. Malthus in LondonHouse-Yard. 1705 (Luttrell, 12 June). $2^{\circ}$; (i-ii) 1-13 pp. L, O, CtY, InU

By 1705 Scotland enjoyed the dubious advantage of having a series of epithets which were applied to her by her enemies on all suitable occasions: "A trip lately to Scotland" used them all. The Scots were lazy, lousy, scabby, and tainted with the itch. They were as well republican, subject to fanaticism, unruly and ungovernable, and-worst of all-poor and shiftless. The Presbyterian church and its ministers were ranting, undisciplined, and intolerant; and Scotland itself was a barren wilderness. The elegy printed at the conclusion was an afterthought to exploit the Green affair, and itself was of no consequence. It was a mean and nasty work.

492 The triumph of union: with the Muse's address for the consummation of it in the Parliament of Great Britain. London. 1707. $4^{\circ}$; 1-2 3-16 pp. Nahum Tate. L, O

Tate's glorification of the union was similar to much of the commemorative verse produced by semi-official or official poets of the period. It was a poem suitable to the occasion, with ample praise both for the union and for Anne.

493 A true and impartial account of the proceedings against Capt Green and his crew, together with the confession of severals of them under sentence of death. 1705 (dated 2 May). $1 / 2^{\circ}$; one side. $\quad$ E, O

The Scots were not unaware of the great ado in England over the trial and execution of Captain Green for piracy against a Scottish ship. This paper presented the Scottish side of that affair, argued that the three executed men had been given a fair trial, and termed the entire process carefully and properly handled.

494 The true-born Britain. Written by the author of the True-born Englishman. London. 1707. $8^{\circ} ; 12-8$ pp. (Daniel Defoe.)

In this poem, written to glorify the union, the author's primary purpose was to show the impact of the union upon the war then in progress, and to warn all that a united Britain would be an even greater foe than an England alone. It was a poem to union, but also to a militant and victorious new Britain. No. 134 apparently was written as a companion piece to it. 
of Stirstrachen, Esq; in the Parish of Ore, in Galloway. Composed in the Prison House of Dalkeith, by Robert Ker: Anno 1711. Edinburgh, printed by John Reid, in Bells Wynd. 1711. 8 ; 1-2 3-16 pp. RoberT Ker.

$\mathrm{E}$

For Robert Ker, the affairs of the church as he saw them were in perilous shape. This tract is a long and bitter harangue against compromises within and without the church which in his opinion had taken it far from where it should have been. While primarily a diatribe against alterations within the Presbyterian church, his lamentation also commonted on changes necessitated by the union and by the subsequent compromises.

496 A true copy of a letter from the Reverend Mr. Greenshields. From the Goal of Edinburgh, where he now lies, only for reading the English liturgy there in a meeting-house. Directed to a clergy-man in the city of London. Tolbooth of Edinburgh. 1709 (dated 17 September). $4^{\circ} ; 1-4$ pp. JaMES GrenNShields. E, O

The Greenshields case, which would become one of the most celebrated in Episcopal annals during the reign of Anne, was in its early stages when Greenshields wrote this short piece to publicize and to explain his case. He was an Episcopal minister in Edinburgh, arrested and imprisoned for having used the English service and in other ways having caused a disturbance in that city.

497 The true Scots genius, reviving. A poem. Written upon occasion of the resolve past in Parliament, the 17 th of July $1704 . . .1704 .4^{\circ} ; 1-34-8 \mathrm{pp}$. (William Forbes; attribution dubious.)

$\mathrm{L}, \mathrm{E}, \mathrm{CtY}, \mathrm{InU}$

This poem might best be described as a patriotic harangue. The author sought to induce the Scots to shrug off a hundred years of oppression by the English; certainly this was not an appcal to reason and compromisc.

A true state of the case of the Reverend Mr. Greenshields, now prisoner in the Tolbooth in Edinburgh, for reading Common-Prayer, in an Episcopal congregation there; tho' qualify'd by taking the oaths, and praying for the Queen and Princess Sophia. With copies of several original papers relating to his accusation, defence, imprisonment and appeal, first to the Lords of the Session in North-Britain, and since to the House of Lords. London: printed for Jonah Bowyer, at the Rose in Ludgate-street, near the West-End of St. Paul's Church. 1710 (ca. 23 February). $8^{\circ}$; 1-45-31 32 pp. (Maxwell, may actually have been written by James Greenshields himself.) L, E, CtY, $\mathrm{DFo}$, InU, KU

[variant:] . . imprisonment, and appeal. . . London: printed for Jonah Bowyer, at the Rose in Ludgate-Street. 1710. $2^{\circ}$; (i-iv) 1-24 pp. L, E

There can be no doubt that the Rev. Mr. Greenshields acted in behalf of the Episcopal clergy of Scotland, and this tract sought to make the case for that church as clear and concise as possible. Greenshields attempted to conduct services in Edinburgh according to the Episcopal rites and was arrested as a result of his defiance of the established religion and procedure. The author of this work argued for a toleration and a moderation, and 
not for the restoration of episcopacy as the established church. The inclusion of official documents makes this work particularly valuable. It was answered by Nos. 152 and 325 .

Tryal. SEE: Trial.

499 Two great questions considered, I. What is the obligation of Parliaments to the addresses or petitions of the people, and what the duty of the addressers? II. Whether the obligation of the Covenant or the other national engagements, is concern'd in the Treaty of Union? Being a sixth essay at removing national prejudices against the union. [Edinburgh]. 1707 (Moore, January; Healey, Defoe promised in a letter of 17 January to send a copy to Harley). $4^{\circ}$; 1-2 3-31 32 pp. (Daniel Defoe.) L, E, O, LU-G, CtY, DFo, InU, $\mathrm{MH}$

In this sixth essay Defoc was forced from his generalizations about the goodness of the union into the complicated debate over matters religious. The more orthodox Presbyterians of Scotland were convinced that the covenant had been broken and that association with the Anglicans of England would lead to damnation, if not worse. The petitions which flowed into Edinburgh against the union sought to impress the Parliament with a "public" outcry against union. Defoe countered with the assertion that the petitions did not represent Scotland nor was the union between the Church of Scotland and the Church of England, but rather between the Parliaments of Scotland and England. Being unable to calm these religious fanatics, Defoe sought to discredit them. This was the last of Defoe's Essay series, the others being Nos. 119, 120, 121, 138, and 135. This tract also answered No. 187, and James Hog's The covenunts of redemption and grace displayed, Edinburgh, 1706/7, which is not included in this checklist.

500 Two kingdoms made one, in a dialogue between St. George and St. Andrew; occasioned by the union, that commenced on Thursday, the first of May, 1707. [London] Printed, and sold by J. Morphew. 1707. $1 / 2^{\circ} ; 1-2 \mathrm{pp}$.

L

This work is typical of the poetry written to reflect the reaction to the union in 1707. It primarily is of interest for its use of St. George and St. Andrew, but in all other ways it reflects the typical praise of Anne and limited support for the union.

501 Two letters concerning the present union, from a peer in Scotland to a peer in England. [Edinburgh]. 1706. $4^{\circ}$; $1-23-28$ pp. George Mackenzie, Earl of Cromarty. L, E, CtY, DFo

This is a direct reprint of Nos. 212 and 378.

502

Two overtures humbly offered to his Grace John Duke of Argyll, Her Majesties High Commissioner, and the right Honourable the Estates of Parliament. ... [Edinburgh? 1705 ?]. $4^{\circ} ; 1-8$ pp. (JoHN Law.) E, MH

The state of the economy in Scotland was of great concern to many in the reign of Anne. This tract sought to resolve some of those problems through a reform of the currency and through the introduction of other forms of currency to repay the debts of the state. It was 
one of the schemes for which Law would become infamous over the next few decades. Other pamphlets on this subject are Nos. 122 and 276.

503 Two speeches; the one relating to trade. (Spoken in the present Parliament of Scotland). The other relating to the limitations of the crown thereof. Edinburgh. $1703.4^{\circ} ; 1-8$ pp. (Second speech by John Hamilton.) LU-G

The author sought to present the problems of a weaker power-Scotland-faced with the necessity of treating with a greater power-England-who could not be trusted to observe the terms of any agreement. The great power of England, whether in matters of economics, politics, or military ability, prcoccupied the author or authors of these speeches as they tried to find ways by which Scotland could protect her own interest.

504 Two (united) are better than one alone. A thanksgiving sermon upon the union of the two kingdoms, of England and Scotland, preach'd at Hackney, May 1. 1707. London: printed by 'T. Ilive, for Jonathan Robinson, at the Golden-Lion in St. Paul's Church-yard. 1707. $8^{\circ} ; 1-23-32$ pp. IsaAc Bates (formerly erroneously attributed to "John Bates"). L, E, O

. The second edition. London: printed by T. Ilive, for Jonathan Robinson, at the Golden-Lion in St. Paul's Church-yard. 1707. $8^{\circ} ; 1-2$ 3-32 pp. E, DFo, InU

Bates, a dissenter, was for the union, and urged others to support it as well. He felt the union was in the best interest of all of Britain, and that England had lost little but a name while gaining a people with a good character and much to contribute. He did fear the Highlanders, who were against the union and who were Popish and Jacobites, and he admonished the high churchmen who were too vocal against the union. But overall, be felt a multiplicity of religions was no disadvantage, and saw only the Jacobites, the French, and the Catholics as against a good union.

505 Unio Politico-Poetico-Joco-Seria. Written in the latter end of the year 1703: and afterwards, as occasion offered, very much enlarged, in severall paragraphs. By the author of Tripatriarchicon. . . E Edinburgh. Printed by the author. 1706. $4^{\circ}$; 1-2 3-14 1515 17-32 pp. (Andrew Symson.) L, E, InU

\section{O, DFo}

Edinburgh. printed by the author. $1706.8^{\circ} ; 1-23-32 \mathrm{pp}$.

This poem of more than a thousand lines is not much in the way of poetry, but it does cover many of the arguments for and against a union between England and Scotland. While the overall thrust of the poem seerns to have been for a union, the author under disguise of jest and refutation included much against the union as well. It was an unusual form in which to present this material, but the arguments were neither original nor well stated. 
for John Wyat, at the Rose in St. Paul's Church-Yard. 1707 (Luttrell, 27 March; published before 2 April). $2^{\circ}$; $1-23-78$ blk. pp. C.D. ReCTor of K- IN S(Charles Darby). O, InU

This hymn in praise of the union might best be described as a poem in praise of Anne, to whom all credit was given for that successful treaty. Among the union poems, it is better than most in a simple, direct way.

507 The union. A poem, inscrib'd to the Right Honourable Lord Marquiss of Granby, One of Her Majesty's Commissioners for the Scotch union. . . . London, printed: and sold by J. Morphew, near Stationers Hall. 1707 (Luttrell, 27 March ). $2^{\circ}$; (i-iv) 1-8 pp. Mr. [Edward] Vernon. E, CtY, InU, MH, KU

This most ambitious of poems sought to commemorate the union in terms grand enough for the occasion. The poet's ambition was to encourage a union of affection to match the union of rights already achieved. All were praised, from Anne to Marlborough, although with some slight preference for the English over the Scots. It cannot be counted among the better poetry of the period.

508 Union and no union. Being an enquiry into the grievances of the Scots. And how far they are right or wrong, who alledge that the union is dissolved. London: printed, and sold by John Baker at the Black-Boy in Pater-Noster-Row. 1713 (Moore, 2 June). $8^{\circ}$ (turned chain lines); 1-2 3-24 pp. (Daniel Defoe.) L, E, LU-G, CtY, InU, MH

Writing to combat growing anger in Scotland over the malt tax, the author first discussed the areas of dissatisfaction in both countries, reducing them to differences between Jacobites and Hanoverians, differences between Episcopalians and Presbyterians, and disputes over taxes. The malt tax--ind charges made in Scotland that the treaty had been broken--constituted the major part of this work, which argued that the action taken in Parliament had not been a violation of the treaty and that there was no cause for a feeling of special aggrievement in Scotland. As such it was a government panphlet written to justify an action taken there which had encouraged discontent in Scotland.

509 The Union-Proverb: Viz. If Skiddaw has a cap, Scruffell wots full well of that. Setting forth, I. The necessity of uniting. II. The good consequences of uniting. III. The happy union of England and Scotland, in case of a forcign invasion. ... London: printed for George Sawbridge, at the Three Golden Flower-de-Luces in Little Britain. [1708] (Lee, 13 March). $8^{\circ}$; (i-vii viii blk. $i x-x$, contents) $1-14 \mathrm{pp}$. (Anonymous, although formerly attributed to Daniel Defoe.) $\mathrm{L}, \mathrm{O}, \mathrm{CtY}, \mathrm{MH}$ (lacking contents)

. London printed: and sold by J. Morphew near Stationers Hall. [1708]. $8^{\circ}$; (i-vii viii blk.) 1-14 15-16 blk. pp. E, MH

This appeal to unity against a foreign invasion probably was written in 1708 , when the possibility of Firench aggression was being widely discussed. It was a pamphlet which attempted to present the best of both Scotland and England, and to placate the Scots in 
particular by pointing out faults and flaws in the English (who of course were not reluctant to find similar ones in Scotland). Its theme was unity and support for the union.

510 Union, the strength of a people. Considered in a sermon, preach'd in Bartholomew-Close, on May the first, 1707. Being the day appointed by Her Majesty, for a general thanksgiving for the happy union of the two kingdoms of England and Scotland, in Great Britain. London, printed by J. Humphreys, for John Lawrence at the Angel in the Poultry. 1707. $8^{\circ} ; 1-23-16$ pp. Thomas Freke. L, O, CtY

Comprehension and toleration were the key phrases and thoughts for the dissenting clergyman who wished to say nothing which might be misunderstood by the Anglicans.

511 The union topknot: or advice to the semptress a-la-mode. London: printed by B. Bragge. 1707 (ca. 18 April). $1707.4^{\circ} ; 1-4$ pp. OCU

- London: printed for B. Braggs, in Pater-Noster-Row. 1707. $4^{\circ}$;

[variant:] ... semptriss. ... London, printed for B. Breggs. 1707. $4^{\circ} ; 1-4$ pp. LG

The author of this verse was not all that interested in Scotland; the union was simply the occasion for exhibiting a clever piece of urbane wit. He felt the Scots were living off England and that in general the union was not such a marvelous thing.

512 Unto His Grace, Her Majesties High Commissioner and the most Honourable the Estates of Parliament, the representation and petition of the Commission of the General Assembly of this national Church of Scotland. Edinburgh. 1707 (dated 16 January). $1 / 2^{\circ}$; one side. L, E, DFo

Neither in England nor in Scotland were men willing to allow another religion to exist unchallenged or unmolested. This petition challenged the religious settlement in the Treaty of Union, and argued that the treaty as it was then written would give to the Church of England an absolute right to protect itself as an Anglican-dominated Parliament saw fit. To agree to maintain the Church of England was, to some Presbyterians, an involvement in guilt.

513 Unto His Grace, Her Majesties High Commissioner, and the Right Honourable Estates of Parliament; the humble address of the barons and freeholders, within the stewartry of Kirkudbright. [1706] (Defoe History, 18 November). $1 / 2^{\circ}$; one side. E, O, DFo

This protest against the union undoubtedly dates from the autumn of 1706 , when the Parliament of Scotland was debating the treaty. The objection was to the loss of sovereignty, liberty, and independence; thus it did not differ from other such petitions handed in during that session. 
Honourable Estates of Parliament. The the (!) humble address of the Presbytrie of Lanerk. [Edinburgh. 1706] (Bib. Linds., 18 November). 1/2 ${ }^{\circ}$; one side. $\quad L, E, D F o$

Like the other protestations and petitions entered with Parliament in the fall of 1706, this paper sought to prevent the union as it was then defined by the articles agreed upon by the commissioners. The petitioners argued that they were not against a union as such, but rather against this one which threatened Scotland's laws, liberties, Parliament, andmost important-her clurch.

515 Unto His Grace, Her Majesties High Commissioner and the Right Honourable the Estates of Parliament, the humble address of the Presbytry of Hamilton. [Edinburgh. 1706] (Defoe History, 11 December; Bib. Linds., 18 November). $12^{\circ}$; one side. L, DFo

The elders and ministers of the Presbytery of Hamilton protested against the union with England as it was being considered. In particular, the Presbytery wanted union postponed until a General Assembly of the Church of Scotland might be convened to treat on behalf of that church. Overall, their primary concern was for the Church of Scotland, which they felt was endangered by the union as it was defined. The signatories included such men as Francis Borland, Archibald Foyer, and Robert Wyllie.

516 Unto His Grace, Her Majesty's high Commissioner, and the Right Honourable the Estates of Parliament, the humble representation and petition of the Commission of the General Assembly of this national Church. [Edinburgh. 1706] (Defoe History; Bib. Linds., agreed to 8 November). $1 / 2^{\circ}$; one side. L, E, DFo

The Church of Scotland throughout 1706 and 1707 argued that the proposed terms of the Treaty of Union did not adequately protect the established religion. In particular, as seen in this protest, they felt that the application of the Sacramental Test, the oaths, and the inclusion of bishops in the new Parliament were threats to Presbyterians.

517 A view of the management of the late Scotch ministry, with respect to the Protestant succession, union, \&cc. London. 1709 (dated 15 November 1708). $4^{\circ} ; 1-23-3132$ blank pp. L, E, CtY, DFo, InU, MH, KU

This pamphlet, written in the autumn of 1708 , supported demands made by the Squadrone, one of the Scottish factions, to replace the existing ministry in London and to capture the management of affairs in the north for themselves. The author traced the recent history of politics in Scotland, paying particular attention to the reign of Anne, and exposing the mistakes of those who managed her affairs. This highly political tract appealed primarily to those aware of the intricacies of British politics in 1708, and illustrated the shift from pamphlets for or against union to those for or against official policy in Great Britain. This was reprinted in Somers as "A brief view of the late Scots ministry." Cf. No. 45.

518 A vindication of the Church of Scotland, from the malicious and groundless aspersions of Mr. William Dugud. With an introductory epistle in 
defence of the Church of Scotland, from the charge of persecution: and the behaviour of the Dissenters in England. London: printed for A. Bell, at the Bible and Cross-Keys in Cornhill. 1714 (dated 6 July; published ca. 17 July). $8^{\circ}$; (i-xlizi xliv blk.) 1-72 pp. Andrew Lowe. L, E, O

The author presented the position of the established Church of Scotland, which rejected the right of patronage as detrimental to its church and religion and as a violation of the safeguards in the Treaty of Union. In particular, he argued that the point in question was the forced acceptance of a minister without regard for his abjlity or character. The pamphlet was an extended cxamination not only of the actual controversy, but of the issues at stake in the dispute and their history and development. It was an answer to No. 360.

519 A vindication of the ecclesiastical part of Sir James Dalrymple's Historical Collections: in answer to a late pamphlet, intituled, The life of the Reverend Mr. John Sage, \&c. Wherein some things are added towards the clearing the ancient government of the Church of Scotland from the mistakes of a late author. Together with a defence of what Sir James hath advanced concerning the opinion of the Scottish historians in relation to King Robert the Second's marriage with Elizabeth Mure, in answer to Mr. John Sage his criticism on that subject in his introduction to Hawthornden's works. Edinburgh, printed by the heirs and successors of Andrew Anderson, for David Scot, John Paton, and William Brown, booksellers. 1714. $8^{\circ}$; ( $i$ ii, advt. iii-vii viii blk.) 1-73 74 blk. pp. (James Dalrymple.) L, E, InU, KU

[variant:] (i ii, advt.iii-ix $x$ blk.) 1-73 74 blk. pp. $\mathrm{KU}$

The accumulation of charges and counter-charges had grown quite numerous by 1714 , and this work by Dalrymple typically sought to do little more than refute allegations and corrections made by Gillan in No. 238. The isste at stake was the independence and the development of the church in Scotland, and the degree to which the church in England did or did not influence that development. The sequence of the debate was: Nos. 362, 235, $482,236,156,450,35,188,160,81,451,483,238,519,422$.

520

A vindication of the false aspersions laid against the Judges of Admiralty in Scotland by Green's associats in England. London printed, and Edinburgh re-printed by G. J. $1705.12^{\circ}$; both sides. E, O

The charges brought against the Scottish courts-and in particular the Judges of Admiralty who had tried Captain Green-werc vicious and unrelenting. The publication of the supposed speeches of Green and Madder infuriated many in England who knew little of the Scottish court system. This paper attempted to vindicate that system of justice and to assert that Green and Madder had received a fair trial and were guilty as charged of piracy against a Scottish ship.

521 A vindication of the ministers and ruling elders, in the Church of Scotland, who have refused the Oath of Abjuration. Wherein the inexpediency and unlawfulness of the said oath, are further cleared and evinced. In two parts. Part I. Contains new additional arguments, \&c. Part II. Consists of 
answers to the six pamphlets, \&c. [Edinburgh]. 1713 (E ms. note, March). $4^{\circ} ; 12-36 \mathrm{pp}$. (Anonymous; sometimes erroneously attributed to Alexander Lauder.) L, E

Opposition to the Oath of $\Lambda$ bjuration was not limited to Jacobites, for many Protestants also opposed it. 'This writer was one of those who viewed it as inmoral, sinful, impractical, unconstitutional, anti-Scottish, and thoroughly unwarranted. This blanket denunciation, coupled with elaborate efforts to substantiate his spccific arguments, constituted a long and complicated tract.

522 A vindication of the ministers and ruling elders, in the Church of Scotland, who have refused the Oath of Abjuration. Wherein, the inexpediency and unlawfulness of the said oath, are further cleared and evinc'd. Part II. Containing answers to six pamphlets, emitted in favours of the foresaid oath; and discovering the weakness of jurants their plea, in their artful evasions, smoothings, and precisions. [Edinburgh]. 1713. $4^{\circ}$; 1-2 3-64 pp. (Anonymous; sometimes erroneously attributed to Alexander Lauder.) L, E, MH

This refutation of some six pamphlets which supported the Oath of Abjuration recited the errors in logic, history, theology, or law made by the writers of the pamphlets. It was a work which stood squarely against the oath, but which refused to accept the labcl of "Jacobite." CE. Nos. 267, 271, and 272.

523 A vindication of the ministers and ruling elders of the Church of Scotland, who have taken the Abjuration; wherein it is made cvident, that they are not thereby engaged in their stations, to oblige the successor, when he comes to the crown, to join in communion with the Church of England, as some ignorant people are made to belicve. Edinburgh, printed by John Moncur, at the foot of the Bull Closs, and sold by the booksellers in Edinburgh, Glasgow and Aberdeen. 1712 (November). $4^{\circ} ; 1-23-3839-40$ blk. pp. (Alexander LAUDER.) L, E, KU

The decision by many of the more moderate of the Presbyterian clergy of Scotland to take the Oath of Abjuration enraged their more orthodox brethren, who saw it as an abandonment of Presbyterianism. Those who tried to counter such arguments attempted to show that the oath was not really unacceptable, and that misunderstandings as to its meaning occasioned much of the difficulty. This was one of the most competent and legalistic of such endeavors.

524 Vis Unita Fortior. The original, nature, and advantages of union: or the imitation of Christ's kingdom, the duty and security of all other kingdoms. A sermon preach'd May 1. 1707. Upon the wonderful and happy union of the two ancient kingdoms, that day compleated. London, printed for Rob. Vincent in Cliffords-Inn-Lane in Fleetstreet. $1707.4^{\circ} ; 1-45-24$ pp. Richard Collins. L

This lukewarm sermon on the union stressed the duty of men to support the Queen and her policy toward union. Collins' primary concern was to defuse the extremists, to en- 
courage loyalty to the monarch, and to urge opposition to the Papists and to the French. Hopefully, God and Anne would see the British through this situation.

525 The the (!) vision, a poem. [Edinburgh. 1706] (ca. 27-28 November). $4^{\circ} ; 12-4$ pp. (DANIEL Defoe). E, CtY (Foxon \#D186, variant of this edition at $\mathrm{MB}$ )

[another edition] (partly reset; empty parentheses above title, where superfluous "the" had been). L, E, O

The Vision. A poem being an answer to the Lord Beilhaven's speech. By a person of quality. Printed at Edinburgh and reprinted at London for Benjamin Bragg, at the Black Raven in Pater-noster-Row. 1706 (Moore, 7 December). $4^{\circ} ; 1-4$ pp. L

Of all the poetry provoked by the Act of Union, this piece was the most interesting, a reply to Lord Belhaven's "prophetic" speech in which a desolated and violated Scotland would result from union. Defoe countered with this piece of verse, rather sarcastically ridiculing the nobleman with visions of too much prosperity. The sequence of the debate was: No. 241 , which was answered by Nos. 88 and 398 , as well as by No. 30 , which was followed by Nos. $525,355,332,374$, and 118 .

526 A voice from the north or an answer to the voice from the south, writen by the Presbyterians of Scotland. to the dissenters in England, a poem. [Edinburgh. 1707]. $1 / 2^{\circ}$; both sides. E, MH

Opposition to the union was not destined to disappear very soon. This poem stressed the "Judas" aspect of the treaty, asserting that men voted for it in the Scottish Parliament more for gain than from conviction. The religious aspects of the matter continued to predominate with some Scots: the abandoning of the established church to the whim of the Anglican-dominated Parliament was a constant theme. Indeed, it was the insecurity of the church which figured most prominently in this bit of doggerel. This was an answer to No. 527 .

527 A voice from the south: or, an address from some Protestant dissenters in England to the Kirk of Scotland. [Edinburgh. 1707] (E ms. note, 10 April; Healey, possibly mentioned in Defoe letter of 12 April; Moore, April, and reprinted in the 10 and 15 May numbers of the Review). $4^{\circ} ; 1-8 \mathrm{pp}$. (Daniel Defoe.) E

With union already accomplished, Defoe now sought to temper some of the remaining and still shrill doubts of the Presbyterian Church of Scotland. Those responsible Presbyterians in North Britain were admonished to calm themselves, to accept the security of their Kirk as guaranteed in the treaty, and to see the more positive aspects of a union. It was to be hoped that all men would live together with reasonable peace and toleration. Certainly the author presented a most positive and optimistic outlook for the Presbyterians if they would but accept it. This was answered in No. 526. 
over the whole island and for making good the damage to the owners of Capt. Greens ship condemned in Scotland. [1705/1707]. $12^{\circ}$; one side. E

With the furor over the seizure of the Worcester and the trial of Captain Green at Edinburgh, it was not surprising that there was reprinted what purported to be an account of the votes of the House of Commons in England, to ask the Queen to award the owners of that ship compensation for their losses.

529 Vulpone: or, remarks on some proceedings in Scotland, relating both to the union, and Protestant succession since the Revolution. In a letter to a Member of Parliament. [London]. 1707 (ca. 10 February). $4^{\circ}$; (i-ii) 1-11 14-15 14-29 30 pp. L, E, O, CrY, DFo, InU, KU

While supposedly written by an Englishman to expose the ministry in Scotland which had endorsed the Articles of Union, this pamphlet displayed a knowledge of Scottish politics rarely evident among the English. The purpose of the work, written while England's Parliament was considering the union, was to provide its opponents in England with sufficient information to discredit the treaty, and to convince them that the Scots' approval had been nothing but a whim of the incumbent government. It is admittedly an expression of only one faction or viewpoint, but it is an amazingly complex introduction to Scottish politics in the reign of Anne.

530 War betwixt the two British kingdoms consider'd, and the dangerous circumstances of each with regard thereto lay'd open; by a full view of the consequences of it on both sides. Being design'd as a perpetual standard, for judging aright of that event; and for promoting peace, and friendly agreement betwixt them, by reasonable concessions from each to each, for the mutual interest and good of both.... London, printed and sold by John Taylor at the Ship in St. Paul's Church Yard. 1705 (no later than early June). $8^{\circ}$; (i-xl) l-165 166-168, advt. pp. (James Hodges.) L, E, O, InU, MH, KU

[variant:] ... Kingdoms. Consider'd ... event: and ... each to each; for.... London, printed by John Taylor: and re-printed in Dublin by F. Dickson near the Theatre Royal in Smock-Alley, for P. Campbell at the Bible on the Blind-Key near Essex-Gate. 1705. $8^{\circ}$; (i-viii) $1-64$ pp. L, DFo

War, whether desired by England or by Scotland, was most imprudent. England had more to lose by it than Scotland. If forced, the Scots could win a war with England, yet Scotland would not go to war unless forced. If necessary, Scotland could maintain her sovereignty upon the death of Anne. Scotland would gain more by union than by independence; and a friendly agreement between the two countries was both preferable and nccessary. Such is a summary of what Hodges provided in somewhat fuller form.

531 A watch-word to Scotland in perilous times. [1704] (E ms. note, August). $1 / 2^{\circ}$; one side. $\mathrm{E}$

While this author had few illusions about England or Anglicanism, he had fewer about France and papism. The horrors of France and of the massacres committed in the name 
of religion there were proof enough to this author that anything was preferable to a French influence.

532 We heard that the Parliament is sitting at Edinburgh, and have seen the Articles of the Union printed at Edinburgh, and their names, that its subscribed with, we have sent our opinion of them. A word to the Unioners and their confederats thee Parliamenters sitting in the Parliament House of Edinburgh. [1706] (after 3 October). $1 / 4^{\circ} ; 1-2$ pp.

$\mathrm{E}$

This hysterical work might best be described as an appeal to arms against those who had taken part in the work of the commission which drew up the Articles of Union. The author suggested that all those involved from Scotland--and most of them he called by name-should be dealt with by the same persons who had becn so angered by the attacks on the African Company and the affair of Captain Green. Opposition to the treaty was almost automatic as far as this writer was concerned.

533 Wednesday 18th of December 1706. Remarks upon a pamphlet intitul'd, The considerations in relation to trade considered, and a short view of our present trade and taxes reviewed. 1706. $4^{\circ} ; 12-8$ pp. (William Black.) E, O, LU-G, CtY

Given the heat of the conflict and the state of the figures available on imports, exports, duties, and taxes, confusion over these items and their relationship to the union were inevitable. In this response, Black defended his figures and attacked those of his opponent. In essence, Black was not as optimistic as was Defoe concerning the economic consequences of the union, and the two therefore debated over the trading and industrial future of Scotland. This was an answer to Defoe's No. 85 , which had in turn responded to two of Black's pamphlets, Nos. 408 and 412.

534 Who wou'd have thought it? A collection of some remarkable passages out of a late pamphlet, entituled, The dissenters vindicated, or a short view of the present state of the Protestant religion in Britain, as it is now profess'd in the Episcopal Church of England, the Presbyterian Church in Scotland, and the dissenters in both: in answer to some reflections in $\mathrm{Mr}$. Webster's two books publish'd in Scotland. London: printed for John Morphew, near Stationer's-Hall. 1707. $4^{\circ} ; 1-4$ pp. (Anonymous, although sometimes attributed to Daniel Defoe.) L, E

By taking out of context passages from Defoe's tracts against Webster (No. 409 in particular), and by carefully selecting particular phrases and giving them a twist, the compiler of this work could present a Defoe to the English public who would be both unfamiliar and unacceptable. It was a clever ploy to use against Defoe, to make him out to be a believer in rather extreme religious and political ideas. The two Webster works referred to in the title arc Nos. 187 and 40.

535 The wolf stript of his shepherd's cloathing. In answer to a late celebrated book intituled Moderation a vertue; wherein the designs of the dissenters against the Church: and their behaviour towards Her Majesty both in 
England and Scotland are laid open. With the case of occasional conformity considered. Humbly offer'd to the consideration of Her Majesty, and her three Estates of Parliament. By one call'd an high-church-man. With my service to Dr. D'Avenant. Sold by the booksellers of London and Westminster. 1704. $4^{\circ}$; (i-ii) 1-2 3-8 9-10 1-83 84 blk. 1-16 pp. (Charles Leslue.) DFo

[variant:] (lacking contents after p. 8). E, O, CtY, $\mathrm{MH}$

[variant:] (lacking contents after p. 8 and appendix, pp. 1-16). L, LU-G [another edition, partly reset] Sold by the booksellers of London and Westminster. 1704. $4^{\circ}$; (i-ii) 1-2 $3081-8384$ blk. pp. InU

[variant:] . . Estates of Parliament. The third edition. By one call'd. . . . Sold by the booksellers of London and Westminster. 1704. $4^{\circ}$; (i-ii) 1-2 3-8 1-66 1-16 pp. $\mathrm{E}$

[variant:] . . Estates of Parliament. The fourth edition. By one call'd. . . Sold by the booksellers of London and Westminster. 1704. $4^{\circ}$; (i-ii) 1-2 3-8 1-66 1-16 pp. O, InU, KU (i-ii 65-66 1-2 3-8 1-64 pp.)

This work is included primarily for its Appendix, which is very high tory and is concerned with Scotland as a refuge for extremist Presbyterians. In the main, Leslie reprinted contemporary materials which related to the Presbyterian "oppression" of the Episcopalians. The identification of the Presbyterians as rabble and as oppressors politically and religiously was a common theme among such men as Leslie. Most of the pamphlet, however, was a refutation of moderation and an affirmation of the rightenusness of high church and Jacobite principles. 


\section{BIOGRAPHIES}

The biographies below are included as an introduction to the scholar who wishes to identify a writer and his works, and we stress that we have not attempted a definitive study of these men. With the exception of the authors of the 1 May 1707 sermons, most writers did not feel free to claim their work, and we list writers of just over half of the entries in this checklist. While some of these pamphleteers are well known indeed, others were-and are-extremely obscure figures. Steele, Swift, and Arbuthnot, for example, are literary figures of the first rank but they were not primarily interested in Anglo-Scottish affairs nor did they contribute much to this controversy. We have not attempted to write definitive biographies of such men here, and we encourage the scholar to turn to the large body of manuscript and printed material available on them. Our contribution has been limited to an introduction and to a short statement of their interest in Anglo-Scottish matters. Defoe on the other hand was closely involved with every aspect of this debate; indeed his contribution was such that a study of Defoe and the Scots is most necessary. Our contribution to that project is restricted to the present checklist which in many ways is a necessary adjunct to any deeper investigation of the topic.

For the more or less obscure authors, we have sought to provide an introduction and to refer the reader when possible to more complete studies. It is apparent to every student of the reign of Anne that there are many such men below the first level who deserve attention and who have not been given it. Historians of religion have done better by the clergymen in Scotland and in England than have the historians of politics and literature for their men. The study of such men as Charles Leslie, William Atwood, James Drake, James Greenshields, or the Symsons, to cite but a few, would serve all working in the field. Indeed, of the biographies which have been written, most are dated and reflect the nineteenth century's eulogistic tendencies. Many were not researched in accordance with contemporary standards, and the seventeenth and eighteenth century man often has been given the "nationalistic" approach of his twentieth century counterpart.

When applicable we have cited the Dictionary of National Biography as an acceptable if dated source of information. In like fashion we have cited $\mathrm{H}$. Scott's Fasti ecclesianae Scoticanae for those clergymen in Scotland who otherwise would have been forgotten. In a few cases we have cited Romney Sedgwick's The House of Commons, 1715-1754. In particular, however, we would like to pay our debt to the late Thomas Maxwell whose dissertation, "The Presbyterian-Episcopalian controversy in Scotland from the Revolution settlement till the accession of George I," has been invaluable to us in this study. It is a work of scholarship which has saved all of us working in the reign of Anne much hardship and for that we are most grateful. 
Arercromby, Patrick. 1656-1718? (DNB). Abercromby was a Scots Jacobite who made one contribution to the union controversy-The Advantages of the Act of Security, compar'd with these of the intended union, 1706. Born in Aberdeenshire, he was educated on the continent but returned to Scotland to take his M.D. degree from the University of St. Andrews. In 1685, in part by the influence of his brother, Lord Glassford, he was made physician to James II, whom he continued to support after the revolution. The Advantages apparently is his only surviving work on the union, for another tract, "A vindication of the same against Mr. De Foe," has not been located. In 1711 he published the first part of a two-volume work, The Martial Atchievements of the Scots Nation, and it is upon this work that his reputation rests. In 1715 he supported the Jacobite cause, and upon the collapse of that rebellion, fled to France, where he died impoverished, between 1716 and 1718. A Roman Catholic, Abercromby seems to have been a typical Jacobite of the more orthodox and constant variety. His abilities as a pamphleteer were not considerable; Defoe, with whom he clashed, easily vanquished him.

Alistair and Henrietta Tayler, Jacobites of Aberdeenshire and Banfshire in the Rising of 1715, 1934, pp. 5-7; George Chalmers, The Life of Thomas Ruddiman, 1794, p. 58; Cavendish D. Abercromby, The Family of Abercromby, 1927, p. 104; Report of the Historical Manuscripts Commission, series 56, Stuart MSS. at Windsor Castle, vol. II, 1904.

Work: No. 16.

ADAMs, William. 1670-1720? (Fasti; Maxwell). At best, Adams is remembered for one pamphlet, $A$ Letter from the Country containing some remarks, in the Defoe-Webster union debate. He was an M.A. from Edinburgh who had been schoolmaster at Prestonpans in 1700, and minister at Humbie in 1701. His tendency toward Episcopalian ideas increasingly brought him into conflict with his congregation and with church authority. In 1706, James Webster, a strong Presbyterian, wrote against the proposed union in Lawful Prejudices, and was answered by Daniel Defoe, who wished to encourage Presbyterians to support the union. Adams entered the fray against Webster and in support of Defoe, who no doubt was amazed at this support from an Episcopalian. Adams' pamphlet was much more an attack upon Webster, the Presbyterian, than it was in support of the union, and there is no evidence that Adams re-entered the union controversy thereafter. In 1714 he commenced business as a printer in Edinburgh and was jailed for two days in 1717 for printing a pamphlet unacceptable to the government.

Works: Nos. 222, 377.

Alexander, William. Among the most obscure of Scottish writers, Alexander was a physician, graduated from Rheims in 1706 and admitted a Fellow of the Royal College of Physicians in 1707. His one known pamphlet in this con- 
troversy is An Essay Shewing that there is no probability of there being so much French interest, as it's certain there's English influence in our present Parliament of Scotland, 1704. In this work his primary concern was with the growing English influence in Scotland; he was not opposed to the union so much as concerned that Scotland had so few options in the making of terms.

Royal College of Physicians: Historical Sketch and Laws of the Royal College of Physicians of Edinburgh from its Institution to 1925, 1925, p. 2.

Work: No. 124.

Anderson, James. 1662-1728. (DNB). A record scholar, Anderson was not by inclination a controversialist. His involvement in the extremely complicated question of Scottish sovereignty was provoked by the exaggerated and often inaccurate assertions of such Englishmen as James Drake and William Atwood. The son of a convenanter, Anderson was trained in the law at Edinburgh, and by 1691 had become a Writer to the Signet. A growing fascination with the study of medieval records, however, led him further away from his profession, and it is as a record scholar that he is best remembered. Since 1688, the questions of Scottish and Irish sovereignty had been debated in the press by such pamphleteers as George Ridpath, James Drake, and William Atwood. Indeed, it was Atwood's The superiority and direct dominion of the imperial crown, 1704, which provoked Anderson to publish his Historical essay showing that the crown of Scotland is imperial and independent in refutation. Anderson was by far the better scholar and was able to discredit his opponents with little effort. The Scottish Parliament rewarded Anderson, but by now he had turned his entire attention to various antiquarian pursuits, none of which was profitable. By 1707, he lacked financial support, and even two years as Postmaster General for Scotland in 1715-1717 did little to repair his finances. He died in 1728 with his masterpiece, Selectus Diplomatum et Numismatum Scotiae Thesaurus, unpublished.

Douglas Duncan, Thomas Ruddiman: A study in Scottish scholarship of the early Eighteenth Century, 1965, pp. 124-125; John Mackintosh, The history of civilization in Scotland, 1892-1896 (corrected edn.), vol. IV, p. 143; William Ferguson, "Imperial Crowns: a neglected facet of the background to the Treaty of Union of 1707," Scottish Historical Review, LIII, 1974, pp. 38-43.

Work: No. 160 .

Arbuthnot, John. 1667-1735. (DNB). With Defoe, Arbuthnot is one of the more illustrious of early eighteenth-century literary figures to write on the Anglo-Scottish question. Born into an Episcopalian family at Arbuthnot in Kincardineshire, he took his degree in medicine at St. Andrews, but was forced to pursue a career in London after his father lost his preferment following the revolution. In London Arbuthnot established a reputation as a wit, scientist, 
and physician, and after successfully treating Prince George of Denmark, was made physician to Queen Anne in October, 1705. Undoubtedly Anne's determination to have a union encouraged the publishing of an anonymous tract entitled $A$ sermon preach'd to the people at the Mercat-Cross of Edinburgh on the subject of the union in December, 1706. It was considered then and later a most eloquent piece of propaganda and enjoyed considerable success. While favorably disposed toward his native Scotland, Arbuthnot rarely returned to the subject; in John Bull still in his senses: being the third part of Law is a bottomless-pit, 1712, he discussed Scotland and dealt kindly with it (in sharp contrast to his friend Swift, who had few such words for Scotland). In the tory circles in which Arbuthnot moved after 1710, the Presbyterians of Scotland were unpopular, and Arbuthnot's favorable portrayal of Scotland is exceptional.

Lester M. Beattie, John Arbuthnot, Mathematician and Satirist, 1935; Henri See and Alexander A. Cormack, "Commercial Relations between France and Scotland in 1707," SIIR, XXIII, 1936, pp. 276-279; George A. Aitken, The Life and Works of John Arbuthnot, M.D., Fellow of the Royal College of Physicians, 1892; William Law Mathieson, Scotland and the union; a history of Scotland from 1695 to 1747, 1905, p. 123; John Arbuthnot, The History of John Bull, edited by Alan W. Bower and Robert A. Erickson, 1976.

Works: No, $181,393$.

Arwood, William. ca. 1650-1712. (DNB). Atwood, born the son of John Atwood of Bloomfield, Essex, attended Queens' College, Cambridge, and the Inner Temple before being called to the bar from Gray's Inn in 1674. A firm supporter of the revolution, Atwood was favored in the reign of William, and between 1700 and 1702 served as Chief Justice of New York. In that position he experienced particularly bad fortune, and was forced to flee in 1702 after being accused, and accusing others, of gross corruption. Back in England, he was unable to clear his name; but his greatest notoriety came through his activities as a fervent supporter of English "imperialism." In 1698 he had infuriated patriotic Irishmen with his History and reasons of the dependency of Ireland, in which he upheld English sovereignty over Ireland. In 1704, in response to various claims advanced by George Ridpath and others, Atwood attacked the position held by some Scots that Scotland was a sovereign power and therefore able to settle the succession as it wished. The superiority and direct dominion, which sought to refute Craig's Scotland's sovereignty asserted and numerous works by Ridpath, was heavy-handed, tedious, shapeless, and thoroughly unacceptable to the Scots; James Anderson responded with the more scholarly work, Historical essay, and Atwood counter-attacked with The Superiority and direct dominion ... reasserted, and with The Scotch patriot unmasked against Ridpath. Throughout his writing career, Atwood seemed genuinely convinced of the validity of his ideas; indeed, there is little doubt that he wished Scotland well. The style as well as content of his works, how- 
ever, provoked controversy and rebuttal. Overall, one must conclude that Atwood lacked either objectivity or charity.

William Ferguson, "Imperial crowns ...," pp. 22-44; Bruce P. Lenman, "The teaching of Scottish history in the Scottish universities," SHR, I.II, 1973, pp. 165-190; Frank H. Ellis, ed. Poems on Affairs of State, 1975, vol. VII, pp. 201-203; The Evening Post, no. 498, 16-18 October 1712.

Works: No. $348,450,451$.

Bannatyne, John. 1641-1707. (Fasti; Maxwell). One of the more obscure of the Presbyterian ministers in Scotland, Bannatyne primarily is known through his pamphlet, A letter from a Presbyterian minister in the country, 1703, in which he vehemently opposed both a toleration for Episcopalians and the restoration of patronage. From 1683 Bannatyne was in difficulties with the authorities for rebellion and treasonable crimes. He was licensed as a minister before 3 April 1688, when he was appointed to serve Lasmahagow, but it was in Lanark that he settled. At the revolution he took possession of the church there, and was posted there legally by 1690 . It is possible that he was of a family from near Lanark, and he often is associated with Sir John Bannatyne of Corehouse near Lanark. He was a member of the assembly in 1690, 1692, and 1693; clerk of the General Assembly 17 December 1695-1699; and a member of the commissions of 1703 and 1706. Prominent in Presbyterian affairs, Bannatyne was a man of fiery temper and firm principles. Vehemently opposed to the union, he died in the year it was completed, 1707.

G. H. Healey, ed., The Letters of Duniel Defoe, 1955, p. 152; John Bannatyne, A letter from a Presbyterian minister in the country, 1703, p. 89.

Works: Nos. 205, 419.

Barclay, George. (Fasti; Maxwell). As one of those ministers disciplined in 1688-89 for refusing to read the proclamation enjoining prayers for William and Mary, Barclay lost his position at Mordington and sometime thereafter moved to Edinburgh. In 1712 he was minister to a congregation in Skinners' Close, Edinburgh, and therefore was eligible to share in the public moneys collected in England to assist the impoverished Episcopal clergymen in Scotland who lacked financial support. Barclay, in George Ridpath's Flying Post, No. 3181, charged that Bishop Rose, who was to distribute the moneys, refused to include any Episcopal minister who prayed for Anne or took the oaths of loyalty to her. Ridpath, who thoroughly enjoyed an opportunity to embarrass the more extreme Jacobite ministers in Scotland, gave the charges wide publicity. Rose replied to the charges in A full vindication of the Right Reverend the Lord Bishop of Edinburgh, and Barclay countered with $A$ full answer for Mr. George Barclay. Because the case of the Episcopal clergy in Scotland had received so much attention among Anglicans in England, the charges and 
counter-charges of Barclay and Rose excited some temporary interest there, but it soon faded-and with it the Rev. George Barclay.

John Parker Lawson, History of the Scottish Episcopal Church from the Revolution to the present time, 1843, p. 212; A contintation of the proceedings of the Convention of the Estates in Scotland, no. 19, 11-14 May 1689.

Work: No. 142.

Ba'tes, Isaac. d. before 4 October 1758. Born in Halifax and probably educated at Edinburgh University, he was chaplain for some time to the Westby family at Revenfield Hall, Rotherham, Yorkshire. By 1697 he was looking for another position, but he was still in the north in January of 1699/1700. Around 1700, Bates made his way to London and to Hoxton (1700-1730) where he had an afternoon congregation of Presbyterians and where he met Dr. Daniel Williams who became a long-time friend. While apparently a learned man, he was not popular in the pulpit and was never able to secure a full-time charge. In theology he was considered a Calvinist and in polity a Presbyterian. His sermon on 1 May 1707 stressed the mutual advantages to be gained by the union. He argued that England would lose nothing but her name and would gain a good friend in the north as well as a good people and a numerous population. Upon his death in or around 1758, Bates was the last surviving trustec of the Dr. Williams's Trust.

Our thanks to Mr. John Creasey, of Dr. Williams's Library, for much of this information; F, J. Powicke, "The Salters' Hall controversy," Congregational Historical Society Transactions, VII, 1916, p. 114.

Work: No. 504.

BeAN, Charles. 1675-1731. An Anglican clergyman, Bean was born the son of Robert Bean of Norton, Worcestershire. He matriculated at Magdalen Hall, Oxford, 4 May 1693, and received his B.A. there 4 February 1696/7. A fellow of Merton College and chaplain to the Earl of Peterborough, he preached a sermon at St. Mary's on 1 May 1707, and immediately was accused by both political extremes of having shown either too slight a zeal for the established church by praising the union, or too slight a respect for William and Anne by showing inadequate zeal for the union. This intolerable situation forced him in early June to publish his sermon to disprove the rumors circulating through Oxford. It was his first publication and by no means one which he enjoyed. His published sermon reflected a fervent desire to avoid antagonizing either his high church brethren at Oxford or the Queen at Westminster. His subsequent career was successful in a limited fashion. He was vicar at Beakesbourne, Kent, in 1710; of Lydd in 1711; rector of Bishopsbourne in 1720, and of Ickham in the same year. He was chaplain to the Prince of Wales in 1719 and continued as chaplain to Charles, Earl of Peterborough. In 1716 he published a sermon 
condemning rebellion, but there was little in his later published works to compare with the controversy surrounding his first publication.

J. Foster, ed., Alumni Oxonienses, being the matriculation register of the university, 1500 . $1714,1891-92$, p. 95.

Work: No. 387.

BLACK, William. (Fasti). An advocate and manufacturer in Scotland, William Black was one of the more qualified and persistent defenders of Scotland's economic interest in the debates over the union. The son of Gilbert Black, baillie of Aberdeen, he was admitted as an advocate 26 July 1692, and before 1707 was involved in the Gordon or North mills near Aberdeen. During much of 1706, he clashed with Defoe in the press over the economic consequences of union for Scotland. Black repeatedly disclaimed opposition to union and rather emphasized his concern over exaggerated claims being made by prounion pamphleteers. He felt that union alone would not resolve Scotland's economic problems and objected to misleading and unsubstantiated statements made by Defoe and others. Overall, Black was something of an economic realist who felt that Scotland's import and export problems would have to be resolved within Scotland itself and that the Treaty of Union should reflect Scotland's best interest as well as that of England. In particular he disagreed with those who felt that union would work immediate economic miracles for Scotland. In addition to his pamphlets on the economics of union, Black also wrote The Privileges of the Royal Burrows, 1707.

William R. Scott, The constitution and finance of English, Scottish and Irish joint-stock companies to 1720, 1910-1912, vol. III, pp. 161-162; Sir Francis James Grant, ed, The Faculty of Advocates in Scotland, 1532-1943, with genealogical notes, 1944; William R. Scott, "Scottish industrial undertakings before the union, Part III," SHR, II, 1905, p. 290.

Works: Nos. 26, 125, 191, 299, 331, 408, 412, 415, 417, 533.

Brady, Nicholas. 1659-1726. (DNB). One of the more prominent of the clergymen writing and publishing sermons on 1 May 1707, Nicholas Brady was an Irishman born in Bandon, County Cork. He was educated at Westminster School, at Christ Church, Oxford, where he received his B.A. in 1682, and at the University of Dublin, where he graduated as M.A. in 1686. A firm supporter of the revolution of 1688, Brady returned to England and was appointed to the church of St. Katherine Cree, in Aldgate (1691-1696); vicar of Richmond, Surrey (1696-1706); and rector of Clapham, Surrey (1706-1726). A firm whig, he was chaplain to William III, to Mary, and to Anne. His most famous work, with Nahum Tate, was a new metrical translation of the psalms, a work which aroused considerable resentment among the more fixed high Anglicans. A prolific writer, Brady published many of his sermons; his 1 May 1707 sermon, therefore, was not exceptional in nature. It is noteworthy pri- 
marily because it reflects the fears and hopes of a moderate Anglican clergyman well placed within court circles in the reigns of William and of Anne. Brady accepted and indeed welcomed the political union of England and Scotland, but he lamented the incompleteness of the religious union, and obviously hoped for the unification of England and Scotland under Anglicanism.

Frank H. Ellis, ed., Pocms on Affairs of State, vol. VI, p. 172; The whole works of Sir james Ware, Dublin, 1739, vol. II, p. 287.

Work: No. 382.

Brown, Andrew. An Andrew Brown in 1703-1706 published several pamphlets on economic matters, and in particular one directly relating to the union of England and Scotland and its economic consequences. It is tempting to credit these works to Andrew Brown, M.D., of Dolphington in Lanarkshire, a fellow of Glasgow College in 1679. This Andrew Brown was related through his mother to Sir John Clerk of Penicuik, a prominent pamphleteer on the union, an economist of note, and one of the commissioners from Scotland to treat of a union. This connection to the Clerks would be most interesting in view of Andrew Brown's negative attitude toward the union, but the link is uncertain. However, the author of the Three Essays, 1706, does claim authorship of an earlier pamphlet, The character of the true publick spirit, 1702. It is tempting to extend the list of works backward to include materials, medical and otherwise, published as early as 1691 . If so, Andrew Brown, M.D., was a man of considerable (if not particularly original) ideas in economics as well as in medicine.

Alexander Duncan, Memorials of the Faculty of Physicians and Surgeons of Glasgow, 1599-1850, 1896, p. 244; T. C. Smout, "The Anglo-Scottish union of 1707," Economic History Review, 2nd series, vol. XVI, 1964, p. 466.

Works: No. 123, 345, 376, 425, 457.

Brown, William. One William Brown is identified as having written The Lamentations of Jeremiah paraphras'd, 1708, but nothing is now known of him. It is possible that this same William Brown wrote Impiety and superstition exposed, 1710. From his verses, Brown was neither a professional poet nor a fan of the union. His view of Scotland after 1707 has a distinctly Jacobite hue; the intent of the pamphlet would most certainly have been to incite discontent in Scotland.

Work: No. 184.

Bruce, Alexander. (DNB [Earl of Kincardine]; Maxwell [Advocate]). "Don A.B.," the author of $A$ discourse of a cavalier gentleman, 1706, often is identified as Sir Alexander Bruce, after 1705 the third Earl of Kincardine, and an old and experienced Episcopalian politician. In 1702 Bruce had been ex- 
pelled from the Parliament of Scotland for a speech which he made which reflected upon the compatibility of monarchy and the Presbyterian religion and church. At that time, he had sat in the Parliament on numerous occasions since 1661, and indeed had served almost every monarch since and including Charles II. While it is possible that he nurtured Jacobite principles similar to those expressed in this pamphlet, there is no evidence to support the argument, and his responsibility, therefore, remains in doubt. Alexander Bruce, advocate, also has been linked with this pamphlet; he too was an ardent Episcopalian who wrote a pamphlet in 1713 which he insisted supported the ancient liberties and independence of Scotland. In 1722 and 1723 he again published works which supported episcopacy against Robert Wodrow and the Presbyterians, but again there is no proof that he wrote and published the earlier pamphlet.

John Macky, Memoirs of the secret services of John Macky, esq; during the reigns of King William, Queen Anne, and King George I...., 1733, p. 253; Sir James Balfour Paul, ed., The Scots peerage; founded on Wood's edition of Sir Robert Douglas's peerage. . . ., 1904-1914, vol. III, pp. 488-489; William Fraser, The Earls of Cromartie, 1876, vol. II, p. 134; Peter Hume Brown, History of Scotland, 1911, vol. III, p. 82.

Work: No. 435.

Burnet, George. fl. 1707. The Rev. George Burnet was not one of the better known ministers of the early eighteenth century. His publication was limited to this one work, a sermon preached 1 May 1707 . While he was said to have been "of Andover," there apparently is little record of his work in that town. He remains one of the more anonymous figures of the period.

Work: No. 392.

Byres, James. 1673-ca. 1702. The son of James, second Laird of Tonley, Aberdeenshire, Byres was a prominent Edinburgh merchant who played an important role in Edinburgh in promoting the ill-fated Company of Scotland. In the early fall of 1699, Byres sailed for Darien or New Caledonia with others to resupply the colony. Byres was to act as one of four new councillors, but the collapse of the colony before they arrived and disagreements among those who came to resupply it led to irreconcilable differences. Byres left Darien and returned to Scotland after much hardship, only to find himself discredited for his actions at Darien. Indeed, his conduct there did seem reprehensible and uncooperative, and his reputation in Edinburgh was ruined. He retired to Rotterdam where he sought to rebuild his reputation with the publication of a pamphlet justifying his conduct. The attempt was not successful, and details of his subsequent career and the date of his death are unknown.

Andrew J. M. Gill, The Families of Moir and Byres, 1885, pp. 114-115; Peter Hume Brown, History of Scotland, 1911, vol. III, p. 35; James S. Barbour, A history of William Paterson and the Darien Company, 1907, p. 143; William Law Mathieson, Scotland and the union; a history of Scotland from 1695 to 1747, 1905, p. 49. 
Work: No. 223.

CaLder, Robert. 1650?-1723. (DNB; Fasti; Maxwell). Among Episcopalian ministers in Scotland, Calder holds first place for combativeness, invective, and garrulity. A native of Elgin, Calder was educated in Aberdeen and before 1689 was minister at Nenthorn near Kelso. At the revolution he lost his position there for refusing to pray for William and Mary. He retired, perhaps to London, but was in Edinburgh again by 1693 when he was imprisoned for illegal religious activities. Released in 1694, he ministered privately to congregations in Newton Don, Elgin, and in Toddrick's Wynd in Edinburgh. His popularity as a preacher was undoubted and at Elgin he defied three prosecutions from the Privy Council before leaving the city. In all meeting houses he used the English service and attempted to introduce the Book of Common Prayer. Early in the reign of Anne he began to publish pamphlets defending the Episcopal service or attacking the Presbyterian system in Scotland. His best known controversy was with the Rev. John Anderson over the nature of the service and over the place of the Episcopalian church in Scotland. Although an extremely prolific writer and preacher, Calder was financially distressed at the end of his life. The generosity of Carstares to him has been cited on many occasions to prove the growing toleration in Scotland. Many of his works were of interest only to his peers.

George Lockhart, A dialogue betwixt a Burgess of Edinburgh, and a gentleman lately arrived in Scotland . . , 1713.

Work: No. 313.

Carstares, William. 1649-1715. (DNB; Fasti; Maxwell). "Cardinal" Carstares was one of the most respected and powerful men in post-revolution Scotland, and indeed often is said to be responsible for the structure of the Presbyterian church in Scotland after 1688. Prior to the revolution he was one of those Scotsmen equally at home in Edinburgh and in the Netherlands, where he studied and spent many years in exile. Opposed to the religious and political policies of Charles II and James II, Carstares was imprisoned on scveral occasions and even tortured. While in exile, he became a friend and adviser to William on matters pertaining to Scotland and at the revolution assumed a position of power close to that monarch. While the death of William curtailed his influence with the crown, Carstares returned to Scotland as one of the most influential of churchmen there, serving as Principal of Edinburgh University from 1703, and four times as Moderator of the General Assembly. Throughout much of the reign of Anne he urged moderation, restraint, and caution upon his fellow clergymen. He supported the Act of Union and the Hanoverian succession, and generally argued that the Church of Scotland was protected from external and internal attack. The growing demand within and 
without Scotland, however, for a greater toleration for the Episcopalian church there and the mood of the Parliament in Westminster alarmed him. The three pamphlets credited to him in 1712 reflect that concern.

John Warrick, The Moderators of the Church of Scotland from 1690 to 1740, 1913, pp. 158-179; Thomas Maxwell, "William III and the Scots Presbyterians: Part Il," Records of the Scottish Church History Society, XV, p. 184; Joseph Maccormick, ed., State-papers and letters addressed to William Carstares. ..., 1774.

Works: Nos. 60, 363, 418.

Chamberlen, Hugh, the elder. 1630/1634-1720? (DNB). Hugh Chamberlen, perhaps the most famous male midwife of the seventeenth century, also was an Englishman with a fair for publicity and an abiding passion for schemes which he felt would increase the wealth of the country and of himself as well. From his family he inherited techniques which enabled him to build a large and fashionable practice in London; indeed in 1688 he was midwife to Mary of Modena but was absent when James III was born. Unwilling to limit his activities to medicine, he embarked upon land bank schemes which fascinated him throughout the reign of William. The collapse of those projects in the late 1690 's forced him to flee into Scotland, where he continued to promote his schemes. While he often wrote on medicine and various economic schemes, he wrote only this one tract on the union. Having little success in Edinburgh, he retired to the Netherlands where he died sometime after 1720 .

John Keith Horsefield, British monetary experiments, 1650-1710, 1960, pp. 55-57, 156-179; J. H. Aveling, The Chamberlens and the Midwifery Forceps, 1882, p. 169.

Work: No. 148.

ClARK, Hugh. A "writer of religious verse," Hugh Clark is a man of unknown character and life. From his religious pamphlets, it seems that he was a defender of the more extreme or Hepburnite elements within the Presbyterian church. His pamphlet against the Oath of Abjuration proved him a man lacking toleration in such matters.

John M'Murdo, An answer to a pamphlet, intituled, The Oath of Abjuration displayed. .., 1713.

Works: Nos. 87, 269.

Clark, James. 1660-1723/1724? (Fasti; Maxwell). A prolific writer of pamphlets, the Rev. James Clark was a prominent Glasgow minister of the established church and a fervent opponent of the union. Born and educated in Edinburgh, Clark was ordained to Dunbar in 1688, translated to Innerwick in 1691, to Dirleton in 1697, and to the Tron, Glasgow, in 1702. Much of Clark's work is religious in nature and not applicable to the larger Anglo-Scottish debate, but his strong feelings against the union did bring him into national 
prominence and embroiled him with Defoe. In the autumn of 1706 , with feelings in Glasgow already inflamed against the union, Clark preached a sermon in which it was reported that he urged violent acts in protest. Whether for this or other reasons, the more concerned citizens of Glasgow celebrated the day of fasting appointed by the Commission of Assembly in a decidedly violent way, and for several days the town was torn by riots. When writing his account of the history of the union, Defoe reported the events in Glasgow and attributed to Clark a prominent role in inciting the citizenry. Before the book was published, Clark secured a copy and protested the description of the sermon; thus began a long and bitter dispute which continued throughout 1708 and 1709. This dispute with Defoe exacted a heavy toll from Clark who never again engaged in the press with the abandon which had characterized his work prior to $1708-1709$.

W. J. Couper, "The writings and controversies of James Clark, minister at Glasgow, 17021724," Records of the Glasgow Bibliographical Society, XI, 1933, pp. 73-95.

Works: Nos. 18, 182, 244, 283, 311, 353.

ClERK, John. 1684-1755. (DNB; Fasti). An cducated and sophisticated politician and pamphleteer, Clerk was born the son and heir of Sir John Clerk of Penicuik. He was educated at Edinburgh and at Leyden where he graduated as Doctor of Law in 1697. Before returning to Scotland in 1699, Clerk traveled on the continent as far as Vienna and Rome. In 1700 he was admitted as an advocate and from 1702 was a Member of Parliament for Whithorn. In 1706 he was appointed one of the commissioners to treat of a union between England and Scotland, and on that commission he played an influential and constructive role. A supporter of the union, he wrote two pamphlets in $\mathbf{1 7 0 6}$ to encourage support in Scotland. Both were well received. In 1707 he was elected to the first Parliament of Britain and in 1708 was made a Baron of the Scottish Exchequer. Thereafter he was noted as a collector of fine antiques, a patron of the arts (in particular a supporter of Allan Ramsay), and as an author of works on antiquarian, legal, commercial, and historical subjects. Among pamphleteers, he displayed more ability than most and achieved considerable success, but his interest in writing was limited in its controversial aspects to this early part of his life.

John M. Gray, ed., Memoirs of the life of Sir John Clerk of Penicuik, Roxburghe Club, 1895; Memoirs of the Life of Sir fohn Clerk of Penicuik, Scottish History Society, 1892.

Works: Nos. 128, 225, 404.

Collins, Richard. 1679-1714. An occasional writer with some three published sermons to his credit during the reign of Anne, Collins was a young Anglican clergyman from Hereford and a graduate of Brasenose College, Oxford (1699). He was chaplain to Mary, Countess Dowager of Fauconberg; vicar of Burham, 
Kent in 1701; of Meopham, Kent in 1707; and rector of Crayford, Kent in 1711. He was Chaplain in Ordinary to Her Majesty's Royal Navy at Chatham. His sermon preached 1 May 1707 was dedicated to Sir Owen Buckingham, M.P., and Lord Mayor of London in 1704-1705. Buckingham was a powerful London merchant and whig politician and a patron of some importance. Collins in his sermon reflected a typical Anglican attitude, for while praising Anne and the union, he sought to avoid extremes in handling the Presbyterians.

J. Foster, ed., Alumni Oxonienses, being the matriculation register of the university, 15001714, 1891-1892, p. 509.

Work: No. 524 .

Crawford, David. 1665-1708? (DNB; Fasti). While primarily a dramatist and antiquarian, Crawford contributed one small item to the historical debate surrounding the union of 1707 . He was a Scot, cducated at the University of Glasgow. He abandoned his interest in the law to pursue one in drama and comedy, but despite three plays between 1700 and 1704, he was not a success. In 1704 he secured the office of Historiographer Royal for Scotland through the influence of the Earl of Cromarty, but that office paid little and demanded less of him. In 1706 he published a work entitled Memoirs of the affairs of Scotland which purported to be "faithfully publish'd from an authentick MS," but which in fact was as much Crawford and other historians as an authentic translation of a sixteenth-century manuscript. Crawford deleted all unfavorable references to Queen Mary and inserted others complimentary to her in an effort to counter works by Buchanan which were critical of Mary Stuart. The controversy which followed was intense but short-lived. Crawford died soon after the union was completed.

T. I. Rae, ed., The union of 1707. Its impact on Scotland, 1974, pp. 103-104; William Fraser, The Earls of Cromartie, 1876, vol. II, pp. 22-24; Denys Hay, "The Historiographers Royal in England and Scotland," SHR, XXX, 1951, p. 21ff.; David Macaree, "IDavid Crawfurd (1665-1708?): His works and their relation to Restoration literature," University of Washington, 1966 (Ph.D.).

Work: No. 249.

Cross-Grove, Henry. 1683-1744. Born in Low Leyton, Essex, Henry CrossGrove was resident in Norwich at least as early as 1706 , when he was associated with the publication of The Norwich Gazette, a local paper with which heand after his death his wife-was associated for almost fifty years. In his politics Cross-Grove was a high tory if not a Jacobite, and in his religion a high Anglican. These views at times brought him into conflict with the more whiggish establishment in Norwich. He also published several pieces of poetry and prose with political overtones but these rarely were issued under his own name. 
Roy M. Wiles, Freshest Advices: Early provincial newspapers in England, 1965; J. B. Williams, "Henry Cross-Grove, Jacobite, Journalist, and Printer," The Library, 3rd series, V, 1914, pp. 206-219. We would like to thank Mr. Frank Sayer, the County Local Studies Librarian for the Norfolk County Council, for much of this information.

Works: Nos. $48,366$.

Dalrymple, David. d. 1721. (DNB; Sedgwick). The fifth son of James, first Viscount Stair, Sir David Dalrymple was a member of the Faculty of Advocates from November, 1688, and was made a baronet in May, 1700. He represented Culross in the Scottish Parliament, 1698-1707, and sat in the British Parliament for the Haddington district of burghs from 1708 until his death. In 1706 he was appointed one of the commissioners to negotiate the union; and from 1709 until his dismissal in 1711 for pro-whig views, he was Lord Advocate of Scotland. He did not regain office until 1720 when he was made auditor to the Scotch exchequer. He does not appear to have been an active writer; his best-known work was a tract published in 1712 against the restoration of lay patronage in Scotland.

Philip Roberts, ed., The diary of Sir David Hamilton, 1709-1714, 1975, p. 56; Geoffrey Holmes, British Politics in the Age of Anne, 1967, p. 243, fn. 90.

Work: No. 7 .

Dalrymple, James. A. 1714. ( $D N B$; Maxwell). A respected antiquarian, Sir James Dalrymple was the second son of James, first Viscount Stair. An advocate, he was admitted to the Faculty, 25 June 1675, and was made a commissary of Edinburgh and one of the principal clerks of the Court of Sessions sometime thereafter. In 1698 he was created a baronet of Nova Scotia. His greatest notoriety was in the reign of Anne when he engaged in a controversy over the historical origins and independence of the church and state of Scotland. His Collections concerning the Scottish history, 1705, in part was a rebuttal to the English writer, William Atwood, who replied in his The superiority and direct dominion... reasserted. Bishop John Gillan also attacked Dalrymple, who published his Vindication in 1714 to justify the positions which he had taken. For the most part, this controversy was not directly concerned with the Anglo-Scottish debate, but in some part it did reflect the ideas and tensions resulting from the controversy surrounding the relations of the two kingdoms. In his religious views, Dalrymple was anti-episcopal, and supported the Presbyterian establishment throughout.

William Ferguson, "Imperial Crowns ...," SHR, LIII, 1974, pp. 40-41.

Works: No. 81, 519 .

Darby, Charles. The Rev. Charles Darby of Kedington, Suffolk, is one of those extremely obscure men whose works most often are attributed to better-known 
authors. From 1680-but increasingly in the reign of Anne-Darby publishcd verse commemorating such events as the loss of Admiral Shovell, the tackers, and (in 1707) the union. The attribution to Darby is based on littlc more than supposition, but The union $A$ poem humbly dedicated to the Queen was signed "C.D. rector of $\mathrm{K}$ - in S-.." From this and other poems, Darby may be termed an Anglican divine of reasonably high church views.

D. F, Foxon, English Verse, 1701-1750, vol. I, pp. 162-163.

Work: No. 506.

Davidson, Robert. d. 1714. The Rev. Robert Davidson, rector of Hayes, Kent, contributed one sermon to those published on 1 May 1707. It was, as he admitted in his preface, his first effort at publication, and it likely was his last. His sermon was that of an Anglican clergyman eager to stress the loyalty due to Anne as Queen, and to emphasize the positive results of the union. He had been curate of Downe, a daughter church of Hayes, from 1693 to 1696, when he became rector of Hayes. Here he remained until his death in 1714.

Our thanks to Dr. Felix Hull, the County Archivist of the Kent Archives Office, for this information.

Work: No. 46.

Defor, Daniel. 1660-1731. (DNB). Few men played such a prominent role in the Anglo-Scottish debate as did Daniel Defoe. Indeed, throughout the reign of Queen Anne, Defoe was writing on Scotland either in pamphlets or in newspapers. As a bankrupt with a large family to support, Defoe had to write for those who would pay him; but in Harlcy he found a patron who recognized his skills and who employed him during the union and after to prepare the way for union in England and in Scotland. Resident in Scotland for extended periods, Defoe knew the Scots as few in London could know them; this knowledge is reflected in his pamphlets. In the middle of every prominent debate, Defoe was evident, but the precise number of works which he contributed to these debates is unknown and perhaps never can be known. A skillful writer, Defoe contributed materials in the style of others in Scotland and England; many works are credited to him simply because they are well written or pursue an argument which he favored. Given the enormous amount of material available on him, little more is needed than a reference to some of the more recent Defoe scholars-J. A. Downic and Maxmillian Novak in particular.

Works: Nos. 15, 17, 25, 28, 30, 39, 49, 85, 106, 109, 119, 120, 121, 135, 138, 145, 152, 158, $162,173,193,214,254,256,258,273,286,301,310,328,332,336,350,356,357,359,369$, $372,380,406,409,446,447,486,494,499,508,525,527$.

Dent, Giles. A. 1707-1712. A Presbyterian minister in London, Giles Dent is 
an elusive figure who either died young or left the ministry soon after 1712 . Possibly he was a ministerial assistant to Edmund Calamy at Westminister, where his sermons gencrally were preached. A staunch defender of the revolution, Dent preached regularly on the November anniversary of the landing of William at Torbay in 1688. His sermon preached on 1 May 1707 reflects a general approach to the union, a safe, whiggish sermon unlikely to offend Anglicans.

Again, our thanks to Mr. John Creasey of Dr. Williams's Library, London, for this information.

Work: No. 454.

Drake, James. 1667-1707. (DNB). A physician and pamphleteer, James Drake on more than one occasion ran afoul of the Parliament and the law because of tory pamphlets which he had written. A man of considerable intellectual ability, he graduated B.A., M.A. (1690), and M.D. (1694) from Caius College, Cambridge. In London he practiced his profession, contributed works on science and medicine to the press, conversed with Dryden and with Tom Brown, and adapted plays by Fletcher for the stage. He wrote The antient and modern stages survey'd, 1699, against Jeremy Collier, but it was as a writer of pamphlets against the whigs that he most excelled. In 1702-1703 he wrote at least five pamphlets against the whigs; for one of them, The history of the last Parliament, 1702, he was tried for libel but acquitted. His Historia AngloScotica, 1703, is best described as a heavy-handed spoof of the weighty tomes then being published in Scotland and in England on the origins of church and state in both kingdoms. This work infuriated the Presbyterians in Scotland who persuaded the Parliament there to order it burnt, which it was. From 1705 through the early spring of 1707, Drake found himself in grave and continuing difficulties with the government and with the law. While his co-authorship of the Memorial of the Church of England has been called into doubt, Drake expressed views in Mercurius Politicus which caused his interrogation. His final illness in part was blamed upon his disappointments and difficulties over his publications.

The memorial of the Church of England, 1705; Frank H. Ellis, ed., Poems on Afairs of State, vol. VII, p. 173, fn. 36; William Ferguson, "Imperial Crowns ...," SHR, LIII, pp. 34-37; The memorial of the Church of England ... wherein is contain'd the life and death of the author..., 1711. For James Drake and The Memorial, see J. A. Downie's forthcoming book on "Robert Harley and the Press."

Work: No. 156.

Dugud, William. A. 1719. (Fasti; Maxwell). A Presbyterian turned Episcopalian, the Rev. William Dugud was the first clergyman to be presented to a position in Scotland after the restoration of patronage in 1712. Licensed in 1710 by the presbytery of Kirkcaldy, Dugud obtained a presentment from the 
Crown in 1712 to the parish of Burntisland. He delivered it to the presbytery of Kirkcaldy, which refused to honor it. He appealed to the Assembly but was deprived of his license for, he claimed, daring to accept the presentment. The Assembly insisted it was because of his character and his disrespect to the established church. In 1714 he was ordained by the Bishop of Carlisle as an Episcopal minister and in that capacity officiated at Arbroath and at Burntisland. To obtain possession of the pulpit at Burntisland, however, he had to raise a mob and seize the church by force. His one publication in the reign of Anne is a justification of his case and an attack upon those who deprived him of his license.

William Maxwell Hetherington, History of the Church of Scotland, 1844 ed., pp. 337-339.

Work: No. 360 .

Dujon, Patrick. 1671?-1728. The Rev. Patrick Dujon was an Anglican clergyman at Doncaster in Yorkshire. He was installed as vicar of St. George's Church in Doncaster in 1706 and was responsible for the building of a vicarage there in 1707. Before 1721/2, he signed himself dean of Doncaster and prebendary of York. He remained at Doncaster until his death in 1728. In his religion and in his politics, Dujon was most "high." He disliked both Scotland and Presbyterians and his reaction to the union was unenthusiastic in the extreme. Of all sermons preached on 1 May 1707, his represents most clearly the attitude taken by many tory clergymen who respected the Queen and constituted authority, but who bitterly resented the alliance with the Scots and with the Church of Scotland. However widespread these views, they were not discreetly published by or credited to clergymen; therefore, the 1 May sermon preached and published by Dujon was signed only "P.D."

Our thanks to Mr. Howarth, the Reference Librarian of the Central Library, Doncaster, for much of this information.

Work: No. 388 .

Dungworth, [Richard?]. The Rev. Mr. Dungworth, the author of The Church of England still persecuted, 1712, is described as chaplain to the Duchess of Buccleuch, but little else is known of him. From his tract, he was a Scottish Episcopalian who wrote to assist the passage of a bill for the relief: of the Episcopalians there, which was being considered in the months of January and February, 1712.

Work: No. 76.

Edwards, John. 1637-1716. (DNB). The Rev. John Edwards might be counted among those clergymen of the Church of England who sought a greater reformation within the church; his Calvinistic views increasingly offended more 
conservative members of the Anglican faith. He was a man of scholarly interests who preferred to remain in or near Cambridge throughout a long and productive life. He first came to Cambridge in 1653 when he entered St. John's College; in 1657 he received the degree of B.A. and in 1661 the M.A. In 1664 he took charge of Trinity Church where he was well received, but St. John's objected to his religious ideas and he resigned his fellowship and entered Trinity College as a fellow commoner. In 1683 he left Cambridge for St. Peter's, Colchester, but remained as vicar there for only three years before returning to Cambridgeshire to write. By 1697 he again was in Cambridge, and in 1699 took the degree of Doctor of Divinity. Thereafter he remained in Cambridge, writing numerous works on theological themes. His general reputation was for fairness and scholarship, but his sermon preached 1 May 1707 is noted more for its attack upon immorality within contemporary society than for wisdom or good humor. Edwards viewed Scotland favorably primarily because of the strict moral codes enforced there by the Presbyterians.

Abel Boyer, The political state of Great Britain, vol. XI, p. 506.

Work: No. 279.

ENock, Richard. b. 1658, fl. 1707. The Rev. Mr. Enock was an Anglican clergyman born the son of George Enock of Sibford Ferris, Oxfordshire. He matriculated at Trinity College, Oxford, on 5 May 1673, and graduated B.A., 1677, and M.A., 1680. From 1682 until 1684 he was rector of Ewarton, Suffolk, and from 1684 rector of Stutton in Suffolk, where he remained through 1707 when he published the sermon which he had preached 1 May 1707. At that time he described himself as rector of Stutton, and dedicated his work to Lady Parker, widow of Sir Philip Parker of Arwarton Hall in Suffolk. Enock, who seems to have published little before or after his sermon, might best be described as a minister of the old school and one who rarely departed from his text, which he examined in great detail and with much high-flown language.

J. Foster, ed., Alumni Oxonienses, being the matriculation register of the university, 15001714, 1891-1892, vol. II, p. 463.

Work: No. 42.

Erskine, Ebenezer. 1680-1754. (DNB; Fasti). The Rev. Ebenezer Erskine is best remembered as the founder of the Scottish Secession Church after 1733. However as early as 1713 he was the center of a religious controversy. Born in Dryburgh, Berwickshire, he was educated at Edinburgh University where he received the degree of M.A. in 1697 . For several years he was tutor to the family of John, Earl of Rothes, but in 1703 was called to Portmoak, Kinrossshire and ordained there in September of that same year. He developed into an extremely popular minister with a large and emotional following; moreover, his religious views were beginning to depart from the more normal pat- 
terns. In 1712 he engaged with the Rev. William Dugud over a divided call to Burntisland with eventual possession going to Dugud. Erskine found himself unable to accept the Oath of Abjuration which required not only rejection of the Pretender, but also acceptance of the principle that the monarch had to be of the Anglican faith. Both ideas were obnoxious to Erskine who refused the oath and who published a pamphlet defending others who refused. Increasing difficulties with the leaders of the established church forced Erskine to remain at Portmoak until 1731. His later career is of little concern in this present study.

Work: No. 126.

FarRfax, Blackerby. fl. 1728. (DNB, under Nathanicl Fairfax). Blackerby Fairfax was the son of a divine and physician who had turned to medicine when his religious views had proved uncongenial to the established church in England after 1660. Blackerby Fairfax was educated at Corpus Christi College, Cambridge, where he received his B.A. degree in 1689 and his M.A. in 1693. He studied medicine at Leyden, as his father had before him, receiving his M.D. degree in 1696. Thereafter he apparently served in the navy as a physician; he retired by or before 1717 . Of the few works which he published, the majority were on medicine or botany; but in 1702 he published a tract entitled $A$ discourse upon the uniting Scotland with England. Of his politics or religion little else is known, and there is little evidence of a lasting interest in Scotland or in the union.

Work: No. 108.

Fletcher, Andrew. 1655-1716. (DNB). Andrew Fletcher holds a special place among Scottish nationalists for his prolonged and determined defence of Scotland against unification with England. Born into a wealthy landed family in Scotland, Fletcher was educated in part by Gilbert Burnet who tutored him, and in part by travels on the continent. Upon his return to Scotland he entered politics as an opponent of the cstablished government. He objected not only to the repressive religious policies pursued by Charles II but also to the absolutist tendencies of the monarchy itself. In politics he was a republican while in religion he was opposed to all forms of dogma. Neither of these ideas endeared him to the government, and he spent the last years of the reign of Charles II and much of the reign of James II in exile in the Netherlands or in Spain (where he was imprisoned for a period before escaping to roam around the countryside in disguise). He returned to England with William in 1688, but he could no more accept the policies of William than he could those of Charles II or James II. From 1690 through the debates on the union, Fletcher promoted the political, economic, and religious independence of Scotland and sought to prevent the disappearance of Scotland in a merger with England. 
From 1698 he wrote on these issues, publishing several influential pamphlets on Darien, the union, and other related items. While respected for his idealism, his determination, his patriotism, and his originality, he was not beyond bitterness, irascibleness, and contrariness. In opposition to the union he was one with the Jacobites, though for different reasons, and was taken into custody in 1708 upon suspicion of supporting a French invasion. Upon his release he retired from politics and turned to agricultural improvements upon his estate. He was a man of education, intelligence, purpose, and refinement. His published works are among the finest in the Scottish debate.

Peter Hume Brown, The History of Scotland, 1911, vol. III, p. 88; William Ferguson, "The making of the Treaty of Union of 1707," SHR, XLIII, 1964, pp. 96-104; William Ferguson, "Imperial Crowns..., , SHR, LIII, 1974, pp. 22-44; Robert A. Scott Macfie, " $\Lambda$ bibliography of Andrew Fletcher of Saltoun," Papers of the Edinburgh Bibliographical Sociesy, IV, 1901, pp. 117-148.

Works: Nos. 6, 281, 441, 445.

Forbes, William. Often described as Forbes of Disblair, this elusive "poet" is best known for his verse published between 1704 and 1722. Most of his work is scurrilous and banal, but on occasion he does hit a tender spot. Of his career little is known nor is his personal life recorded. He apparently is distinct from William Forbes, advocate and professor of law.

Works: Nos. 293, 497.

Freke, Thomas. d. September 1716. An obscure Presbyterian minister, the Rev. Thomas Freke was for some years assistant to both the Rev. John Quick at Batholomew Close and to the Rev. Richard Stratton at Haberdashers' Hall, London. In 1706 he succeeded Quick and his sermons thereafter are published as laving been preached there. Such was the case with his sermon preached 1 May 1707, which was distinguished more by moderation and the desire to avoid offending the Anglicans than by original thought. While reasonably prolific with some eight published sermons between 1704 and 1716, Freke was not a noted minister in London, and his sermons do not seem to have aroused much interest. Indeed his last days-and his marriage to one of two women in his congregation who fought to have him-seem to have aroused more interest than his published works.

William Matthews, ed., The diary of Dudley Ryder, 1715-1716, 1939, p. 318; Walter Wilson, The history and antiquities of Dissenting churches, 1808-1814, vol. III, p. 377.

Work: No. 510 .

GaYNAM, John. An occasional poet, Gaynam wrote verse on the union and later upon ceremonial occasions.

Work: No. 246. 
Gibson, Edmund. 1669-1748. (DNB). A whig churchman who rose to high rank within the church, Edmund Gibson had as his early patron Archbishop Tenison. From his early years at Queen's College, Oxford, he was distinguished for his scholarly ability, having translated Camden's Britannia and dedicated it to Lord Somers. Under the patronage of Archbishop Tenison, he was made domestic chaplain to that prelate, and rector of Lambeth. Active in London circles, he gained a reputation as a shrewd and practical churchman able to use his pen to serve the church or his patron. During the convocation controversy in the last years of the reign of William, Gibson produced works which upheld the ideas of Tenison, but also produced some works of great originality. His Codex Juris Ecclesiae Anglicanae, 1713, was an exceptional piece of scholarship and was long the standard work on Anglican church law. In 1716, after the death of Tenison had deprived him of a patron but emptied one bishopric, Gibson was appointed Bishop of Lincoln. In 1720 he moved from there to the bishopric of London where he was more at home. There he remained until his death in 1748 . Increasingly he was preoccupied with the problem of moral laxity; this appears to have proved a hindrance to his advancement to the archbishopric. A quarrel with Robert Walpole over politics also hindered that promotion which, when it was offered, he declined for reasons of age and health. Without doubt Gibson was an extremely capable and efficient clergyman, well aware, at least during his early career, of the role of patronage in preferment. He had little lasting interest in Scotland and the work cited below is secondary to his primary interest in 1700-1702.

Geoffrcy Francis Andrew Best, Temporal Pillars: Queen Annes' Bounty, the ecclesiastical commissioners, and the Church of England, 1964, pp. 37, 96; Norman Sykes, Edmund Gibson, Bishop of London, 1669-1748; a study in politics and religion in the eighteenth century, 1926.

Work: No. 285.

Grllan, John. d. 1735. (Maxwell). The Rev. John Gillan was an Episcopal minister in Scotland who, during the reign of Anne, was best known for his theological and biographical works, and in particular for his life of the Rev. John Sage. Gillan, who was made Bishop of Dunblane in 1727, was anxious to give a true account of Sage and to vindicate the Episcopal service and structure from attacks by the Presbyterians. His life of Sage brought him into controversy with Sir James Dalrymple and also drew him into the CalderAnderson squabbles; but Gillan was not primarily a pamphleteer, and his works in the main remain firmly within the theological and historical framework.

Works : Nos. 238, 422.

Grant, Francis. 1658/1660-1726. (DNB; Fasti; Maxwell). An eminent lawyer 
and judge, Francis Grant was born into a landed Scottish family of Ballintomb, Morayshire. He studied first at Aberdeen and then at Leyden, where he attracted attention for his legal abilities. He returned to Scotland before the revolution of 1688 and was present in the Assembly of Estates which disposed of the crown of Scotland after the revolution. In the constitutional debates in the Assembly and in the press, Grant was distinguished for his grasp of reality and for his ability to advance arguments in favor of the right of the Assembly to dispose of the crown. In 1691 he was admitted as an advocate and quickly established a large and flourishing practice which attracted not only those loyal to the principles of the revolution but also those who favored the Presbyterian cause. In 1705 he was created a baron of Nova Scotia, and in 1709 was made an ordinary Lord of the Session with the title of Lord Cullen. In the debate surrounding the union, Grant wrote in its favor, contributing several tracts to the controversy. Support for union, however, did not include support for the restoration of patronage, and he remained a firm defender of the Presbyterian church-without, however, advocating intolerance on the part of that church.

Works : Nos. 287, 318, 434.

GrANT, John. 1653-1736. An occasional writer, the Rev. John Grant was an Anglican, born in Hampshire and educated at Sidney Sussex College, Cambridge, where he took his B.A. degree in 1671/2, his M.A. in 1675, and his D.D. in 1709. In 1673 he was made a fellow, and was ordained in 1674. From 1677 he was rector of St. Dunstan's-in-the-West. From 1692 he was prebendary of the Cathedral Church of Rochester, and from 1710 vicar of Kingsdown in Kent. His sermon preached 1 May 1707, which was dedicated to Thomas, Archbishop of Canterbury, was one of only two which he published during the reign of Anne. While stressing the economic advantages which union would bring to Scotland and England, Grant was primarily interested in the union of the two Protestant religions against Roman Catholicism. His sermon was moderate and pro-union.

J. Venn and J. A. Venn, comps., Alumni Cantabrigienses. Part I, 1922-1927, vol. II, p. 248.

Work: No. 385 .

GrAY, James. ca. 1659-at least 1712. (Fasti; Maxwell). A native of Aberdeen, Gray was an Episcopalian educated at King's College, Aberdeen, where he received his M.A. degree in 1676. He was appointed minister at Muirkirk in 1684 but did not reside there and abandoned it in 1688. In 1690 the Parliament restored the Presbyterian minister. Thereafter he apparently worked for the Episcopal party in London, receiving yearly some $£ 100$ for doing so. In 1705 he intruded at Logiebride in Perthshire. While it cannot be stated with abso- 
lute certainly, this is apparently the James Gray who in 1711-1712 published several works on the question of patronage and on the condition of the Episcopal clergy after the Revolution. His adversary was William Carstares, who angered Gray by his Some queries humbly propos'd, [1712].

Works: Nos. 329, 413.

GreENSHtelds, James. fl. 1709. (Maxwell). Although one of the most famous Episcopal clergymen in Scotland in 1709, James Greenshields emerged from obscurity and returned to it at the conclusion of his famous case. He is said to have been the son of a curate who had been ousted at the revolution. He himself was ordained by the Bishop of Ross soon thereafter, but despairing of advancement in Scotland, he retired to Ireland where for thirteen years he was curate of Tynan in Armagh. In 1709 he returned to Scotland, and while in Edinburgh was asked to minister to the English soldiers and others resident there since the union. A freelance minister, with no official connection with the deposed Bishop of Edinburgh, he began to hold services after having taken the Oath of Abjuration. His use of the Book of Common Prayer in an English service infuriated the presbytery of Edinburgh who summoned him to appear before them; he did so, bringing evidence of his good character and his ordination, but they demanded that he cease his services. He refused to accept their jurisdiction and they appealed to the magistrates of Edinburgh, who imprisoned him. He appealed first to the Court of Session (which refused his appeal on the grounds that his ordination was irregular) and then to the House of Lords. Since this was the first such appeal to the Lords and the first test of the right of the magistrates to prohibit Anglican services in Scotland, the case attracted attention in both North and South Britain. The reversal by the Lords of his conviction was followed by passage of the Toleration Act, so hated by the Presbyterians in Scotland, who had thought the Act of Union forever protected the exclusive rights of their religion in Scotland. Having secured for himself a place in the religious history of England and Scotland, the Rev. James Greenshields disappeared from the scene.

Peter Hume Brown, History of Scotland, 1911, vol. III, p. 146; T. E. S. Clarke, A life of Gilbert Burnet, Bishop of Salisbury, 1907, pp. 451-452; 3. H. S. Burleigh, A Church History of Scotland, 1960, p. 274.

Works: Nos. 480, 496.

Hamilton, John. 1656-1708. (DNB). John Hamilton, second Baron Belhaven enjoys a unique place in the literature of the union: he was one of the few noblemen who encouraged the publication of his speeches and one of the few members of the Assembly to deliver and publish a speech which achieved immediate and lasting fame. Lord Belhaven was the eldest son of a prominent judge of the Court of Session, but his title came to him through his wife's 
grandfather, who, having no other male heirs, petitioned that Hamilton might inherit it. From 1681 Hamilton was prominent in Scotland's national affairs, for in that Parliament he declared that Presbyterianism was in danger from popery, and was forced to beg forgiveness from James, Duke of York. In 1688-1689 he embraced with enthusiasm the cause of William and Mary and used his considerable political ability to secure the throne of Scotland for them. At Killiecrankie he commanded a troop of horse, and throughout the reign of William he enjoyed considerable popularity and office. Long a member of the Scottish Privy Council, he also was a member of the Commissions for the Poll Tax and for the Excise. Increasingly, he was interested in and concerned with the advancement of Scotland's economic and political independence. He published a work entitled The Countrey-Man's rudiments, 1699, in an effort to improve agriculture in Scotland, and invested heavily in the Darien scheme. Although he remained a member of the Privy Council, he did not enjoy great popularity with Anne. In 1704-1705 he was a Commissioner of the Scotch Treasury, but for the most part he was out of office and regarded as somewhat difficult. He supported the Act of Security out of principle, for he felt the succession of the House of Hanover preferable to a Roman Catholic Pretender. His loyalty was not to Hanover or Stuart but to what he felt was Scotland's best interest, and that he saw in Presbyterian terms. He opposed the Act of Union for precisely the same reasons-it was not in his opinion in Scotland's best interest. It was with regard to the union that his famous speech (No. 241) was delivered and later published. In 1708 he was called before the Privy Council in London and examined for complicity in the rebellion of 1708 , but he seems to have had little to do with it. A few days after his release on bail, he died, his friends said, of shame and anger at his detention.

Peter Hume Brown, History of Scotland, 1911, vol. III, p. 112; G. H. Healey, ed., The Letters of Daniel Defoe, 1955, p. 142; James E. Handley, Scottish Farming in the Eighteenth Century, 1953, p. 177; John Macky, Memoirs of the Secret Service. . . . 1733, p. 236.

Works: Nos. 118, 239, 240, 241, 355, 374, 429, 431, 433, 503.

HarRIs, Walter. f. 1701. One of the most interesting and elusive of pamphleteers in the Darien controversy, Walter Harris was a Dumbarton man who joined the English navy just before 1688 and who remained there until 1696. In that year he drew his sword on Capt. John Graydon of the Vanguard and thus terminated his naval career for the time being. For some months he hid in London until approached by Haldane of Gleneagle and others on behalf of the newly formed Company of Scotland. He signed on and spent some sixteen months purchasing supplies in the Netherlands and England for the first expedition to Darien. He went with that first convoy, suffered the hardships which that first expedition experienced, and after a shipwreck returned to London via Jamaica with a reputation for desertion. In London he either 
joined Secretary Vernon's paid services or he had long been in that service; in any case he was known to be writing an exposé of the Company of Scotland which came to light as $A$ defence of the Scots abdicating Darien, 1700. This, and $A$ short vindication, 1700 , infuriated the Scots who pressured Parliament to offer a reward for his capture. Both pamphlets provoked a flood of counterattacks by prominent Scots who defended the venture with determination if not with equal invective and imagination. In $1701 \mathrm{Harris}$ continued the attack with two additional pamphlets, both of which defended the English against charges made against them in Scotland. Little more is known of Harris. Prosecution against him for his attack upon Captain Graydon was halted by order of James Vernon. Harris, thereafter forever hated by the Scots who supported Darien, slipped from view.

The London Post, 3-6 January 1700; Walter Harris, $A$ defence of the Scots abdicating Darien, 1700, pp. 13, 25, 49, 149, 160-161; Walter Harris, An enquiry into the Caledonian project, 1701, p. 30; Walter Harris, A new Darien artifice laid open, 1701; Jamcs Byres, $A$ letter to a friend, 1702, pp. 145-146; George Pratt Insh, The Company of Scotland trading to Africa and the Indies, 1932, Pp. 84, 114ff.; George Pratt Insh, The Darien scheme, 1947 , p. 17.

Works: No. 172, 266.

Hodges, James. fl. 1697-1710. Little is known about James Hodges. He apparently was a Scot, residing most of the time in London, who wrote for those opposed to the union and did so with considerable success. In 1697 he is credited with two works on fiscal matters, and in 1700 with a work, $A$ defence of the Scots abdicating Darien, which almost certainly was by Walter Harris. $\mathrm{He}$ also is cited as the author of an Enquiry into the miscarriages of the Scots Colony, 1700, but this work was more probably by George Ridpath. The persistent attempt to identify Hodges with Darien is interesting, but at this time there is no reason to accept the identification as valid. In 1703 Hodges produced The rights and interests of the two British monarchies inquir'd into and clear'd. This work, which enjoyed considerable circulation, brought responses from Defoe, who in the Review carried on a prolonged challenge to it. His next work, A letter from Mr. Hodges at London, 1703, was less controversial; but his War betwixt the two British kingdoms considered, 1705, and The rights and interests . . . Treatise 111 , 1706, all extended his arguments against union. In 1705 he wrote a tract, Considerations and proposals for supplying the present scarsity, similar to those produced in 1697; his last known work was in 1710 when he wrote Essays on several subjects. That Hodges was a paid writer seems fairly certain; that he wrote for the Duke of Hamilton is possible; but evidence is lacking for a positive statement on this aspect of his career.

William Law Mathieson, Scotland and the union: a history of Scotland from 1695 to 1747, 1905, pp. 118, 125; J. Keith Horsefield, British monetary experiments, 1650-1710, 
1960, pp. 68, 105; Daniel Defoc, Review, vol. I1I, no. 149, 14 December 1706, no. 151, 19 Deccmber 1706, no. 156, 31 December 1706.

Works: Nos. 130, 213, 340, 341, 456, 530 .

Hornsy, Charles. Charles Hornby, described as "formerly of Grey's Inn, who belonged to the Pipe Office," was the author of the Caveat against the Whigs, $1711 / 12$.

Works: Nos. 74, 75.

HuMiRex, John. 1621-1719. (DNB). A respected nonconformist, John Humfrey was ordained a Presbyterian minister but was persuaded after the restoration, which he supported, to a reordination by an Episcopal bishop. This he later repented and he spent the period 1662-1.719 as an ejccted minister with congregations in London at Duke's Place, Rosemary Lane, and finally at Boar's Head Yard in Petticoat Lane. Throughout his life Humfrey was known for his religious toleration and for his firm support of monarchy and union. $\mathrm{He}$ was an independent in thought and followed no particular school but his own. After 1688 he lectured the Parliament often and with some slight success on matters of religious freedom, but in 1709 was called before the bar of the House of Commons, and, although released, reprimanded for his advice to them on the Sacramental Tests which he felt worthless. Overall he was a religious maverick with strong personal views and a deep commitment to toleration and religious unity of all believers.

I. A. W. Gunn, Politics und the public interest in the seventeenth century, 1969, pp. 164171.

Works: Nos, 110, 370.

Hutchinson, Francis. 1660-1739. (DNB). In the reign of Queen Anne, the Rev. Francis Hutchinson was a moderately well-known Anglican clergyman with some five published scrmons to his credit and with a comfortable living as curate of St. James's at Bury St. Edmunds. Born in Derbyshire, he was educated at St. Catharine's College, Cambridge, receiving his B.A. from there in 1680 and his M.A. in 1684. In 1692 he moved to Bury St. Edmunds and in 1698 received his D.D. degree from Cambridge. His sermon preached 1 May 1707, which he subsequently published, is distinguished by moderation and reason. He appealed to the advantages of union and the disadvantages of political and religious discord. While recognizing that religion was one of the greatest problems for the Anglican in the matter of the union, he argued that the church had gained, not lost, from the union. In the reigns of George I and II, Hutchinson was made Bishop of Down and Connor, and served as chaplain to George I. In his toleration and moderation, Hutchinson was more typical of the clergy of the later period than of those of the reign of Anne. 
The whole works of Sir James Ware concerning Ireland, $1739-1745$ [i.c. 1746] vol. I, p. 215; The Political State of Great Britain, vol. LVIII, p. 89.

Work: No, 383 .

KeNNETT, White. 1660-1728. (DNB). Bishop Kennett was one of the most controversial and prolific of early eighteenth-century Anglican divines. Educated at Oxford, he achieved notoriety early in his career there with the publication of a pamphlet which sought to vindicate Charles II; but this position he repented during the reign of James II-whom he opposed. In 1688 he supported the revolution, but during the reign of William and Mary he remained primarily in Oxford, where he filled several positions, and in his ministry at Ambrosden. During those years he also developed his knowledge of AngloSaxon language and history and acquired a reputation in antiquarian studies as a careful and intelligent scholar. In 1701-1702, he engaged, among others, Francis Atterbury in a protracted controversy over the role of convocation and also supported the movement to advance Christian knowledge in foreign parts. Throughout the reign of Anne he took part in political and religious disputes, and in 1709-1710 refused to support the high church position relative to the whigs or to the Sacheverell case. This identification with whig politics precluded rapid advancement until the reign of George I, when he was elevated to the rank of Bishop of Peterborough.

Gareth V. Bennett, White Kennett, 1660-1728, Bishop of Peterborough. Study in the political and ecclesiastical history of the early eighteenth century, 1957.

Work: No. 220.

KERR, Robert. fl. 1711-1712. Robert Kerr was a writer of religious doggerel which he published in 1711 as The true Church of Scotland's lamentation, and as $A$ short but true account of the nobility, 1712. Self-styled Fenar of Gilmerton, he appeared to have been imprisoned in Edinburgh's Tolbooth and also in Dalkeith, since the Lamentation is said to have been composed there. His problems would seem to have been not only religious but also financial, since he had debts which he could not discharge. As late as 1717 he published a collection entitled The serious fears of some judgements approaching upon Scotland, but little further is known of him.

D. F. Foxon, English Verse 1701-1750, 1975, vol. I, p. 397; William Stewart, "The Rae Press at Kirkbride and Dumfries," Papers of the Edinburgh Bibliographical Society, vol. VI, p. 110.

Works: Nos. 403, 495.

Kirrwwood, James. 1650-1709. (DNB). Born in Dunbar around 1650, James Kirkwood graduated from Edinburgh University in 1670 with an M.A. and 
accepted a position in the household of the (later) Earl of Breadalbane as his personal chaplain. Under this patronage he was presented with a living at Minto, but was ousted from there for refusing in 1681 to take the tests. He fled to England where his friendship with Gilbert Burnet led to a living at Astwick in Bedfordshire in 1684-1685. While in Scotland, Kirkwood developed an interest in the Highlands and in their language and religious instruction. In England he actively sought to have the Bible translated into Gaelic and to distribute it throughout the Highlands; despite considerable opposition in England and Scotland he successfully sent over 2000 such Bibles into the north. Before 1702 he developed ideas regarding the establishment of libraries in Scotland, but this endeavor was less successful. In 1703 Kirkwood lost his living at Astwick for failing to abjure. He apparently died in 1709 but little is known of his later years, except that he probably lived for some of the time in Scotland.

John Maclnnes, The evangelical movement in the Highlands of Scolland, 1688 to 1800, 1951; Donald Maclean, "Highland libraries in the 18th century," Records of the Glasgow Bibliographical Society, vol. VII, 1923, pp. 36-43; George P. Johnston, "Notices of a collection of MSS. relating to the circulation of the Irish Bibles of 1685 and 1690 in the Highlands and the association of the Rev. James Kirkwood therewith," Papers of the Edinburgh Bibliographical Society, 1901-1904.

Work: No. 89.

LAuder, Alexander. 1668-1719. (Fasti; Maxwell). The Rev. Alexander Lauder was a scholarly Presbyterian minister who rarely abandoned his quiet country ministry in the presbytery of Chirnside. Educated at Edinburgh where he received his M.A. in 1684, he was ordained in 1695 and took charge of Mordington and Lamberton where he remained throughout his career in the church. He was not, however, removed from the religious controversies which disrupted religious life in the reign of Anne. In particular, Lauder reacted to the debates over the nature and jurisdiction of the bishops; and his best-known work, The ancient bishops considered, 1707, was an investigation into the early church and its structure. This work and The divine institution of bishops having churches, 1711, embroiled him in disputes with Episcopal church scholars in Scotland, but Lauder was able to hold his own; his work ranked among the more reliable of the period. He also did not scruple to take the Abjuration Oath in 1712, and his tract, $A$ vindication of the ministers and ruling elders, 1712 , supported those who had taken that oath.

Work: No. 523.

LAw, John. 1671-1729. (DNB). An adventurer and financial genius, John Law was born into a prosperous Scottish family and educated at Edinburgh, where his mathematical ability and interest is public finances soon were noted. Handsome, dissipated, and reckless, he found Scotland less attractive than 
London, where before 1694 he had lost a fortunc and had been outlawed for a duel in which his opponent died. He fled to the continent, where he observed finances in the Netherlands, gambled, and acted as assistant to the English resident there. By 1704 he was in Scotland again; the collapse of the Darien affair and the growing rift between England and Scotland no doubt attracted him. In 1705 he published a tract on Money and trade considered, in which he argued for acceptance of paper specie and for a rcorganization of finances in Scotland. His proposals met with little success, and before 1708 he again was on the continent, gambling and proposing financial systems of one or another sort. Only after the death of Louis XIV did his chance for implementing a scheme become possible. Between 1715 and 1720 he erected a financial structure in Paris which dominated French economic thought for that period, but which ended in a collapse of a spectacular sort. He returned to England for a short time but then ended his life in comparative poverty on the continent.

H. Montgomery Hyde, John Law, 1969; Saxe Bannister, The writings of William Paterson, 1858, vol. I, pp. 2-4.

Works: Nos. 257, 502.

Lesure, Charles. 1650-1722. (DNB; Maxwell). Few pamphleteers combined the determination and ability of Charles Leslie. Born in Dublin, he was educated at Trinity College, receiving his M.A. degree in 1673. He entered the church in 1680 but was deprived in 1689 for refusing to take the oaths to William and Mary. Shortly thereafter he left his charge at Donagh in Monaghan and settled at London. Loyalty to James II and to the Pretender was a constant principle in his life and writings, but loyalty to the Anglican church as he saw it also claimed his attention. He never ceased to give his loyalty to the Pretender nor to attempt the conversion of that Prince to Anglicanism. Leslie regarded all other religions than Anglicanism with extreme distrust, and wrote incessantly against Jews, Quakers, Presbyterians, dissenters, and deists. Mixed marriages, the interaction of church and state, the nature and sanctity of kingship, and the episcopal structure all claimed his time and energy during the reigns of William and Mary and of Anne. On several occasions he exposed situations or events such as the massacre at Glencoe which had been hidden or ignored. Pamphlets, however, were not sufficient for him, and from 1704-1709 he edited a newspaper, The Rehearsal, which did battle with Defoe among others. In 1710 his political views brought him into conflict with the government and he was forced to flee to Berkshire, where he remained incognito until the next year. In April 1711 he escaped to St. Germain, not without jeers from his opponents who remarked upon his flight with some scorn. In 1713, he joined the household of the Pretender, returning to Ireland in 1721, and dying there the next year. In volume Leslie ranks among the most prolific of pamphleteers in the reign of Anne, and wrote more than one pamphlet 
which enjoyed popularity or success. His intolerance and devotion to lost causes, however, deprived him of a large audience and neither then nor later has he received the attention which is his due.

Henry Jenner, ed., Memoirs of the Lord Viscount Dundee, the Highland clans, and the massacre of Glenco, Sc., 1903, p. 112; Sir James Ware, Two books of the writers of lieland: the former of which contains the natives. The latter, those who had any preferment there, 1704, vol. II [of book I], pp. 284-286; Joseph Maccormick, ed., State-papers and letters addressed to William Carstares ..., 1774, pp. 221-223. Material on Leslie is found throughout the literature of the period, primary or secondary.

Works: Nos. 250, 264, 265, 535.

Lockhart, George. 1673-1731. (DNB; Fasti). Born into a wealthy Scottish family, George Lockhart was conspicuous throughout his life for his adherence to the Jacobite cause so abhorrent to his family. He was the son and heir of Sir George Lockhart, Lord President of the Court of Session and the nephew of Lord Wharton, the great whig leader in the reign of Anne. He entered politics in 1702 as M.P. for Edinburgh in the Scottish Assembly, and in 1706 was made a commissioner for the union, much to his own surprise. Long before 1706, his Jacobite principles had been well known in Edinburgh and in England; throughout the meetings on the union he was known to be supplying the Jacobites with information on the progress of that commission. He avoided signing the articles of the commission by not appearing for the last meeting, but did sit in the first Parliament of Great Britain for Edinburgh, and in 1710 and $\mathbf{1 7 1 3}$ for the Wigtown burghs. Immediately after the union he made known his opposition to plans for an immediate rebellion and therefore was not unduly compromised by the rebellion of 1708 . Rather, he sought to influence Anne and to secure legislation which would advance the Jacobite or Episcopal cause in Scotland. He therefore supported the Acts for Toleration and for the Restoration of Patronage so repugnant to the Presbyterians in Scotland. In 1715 he was briefly arrested but released; he immediately resumed his activities and therefore suffered a long imprisonment after the failure of that rebellion. After his release, he worked on various Jacobite projects in Scotland and England until forced in 1727 to flec to the continent where he found the men surrounding the Pretender so inept and unrealistic that he returned to Scotland and retired from politics. He died in a duel in 1731. His Memoirs concerning the affairs of Scotland, 1714, supposedly were published without the author's knowledge or consent.

William Ferguson, "The making of the Treaty of Union of 1707," SHR, vol. XLIII, 1964, p. 104; Harold Williams, ed., The Correspondence of Jonathan Swift, 1963-1965, vol. II, pp. 57-58; Geoffrey Holmes, British Politics in the Age of Anne, 1967, p. 338; George Lockhart, Memoirs concerning the affairs of Scotland, 1714, A. Aufrere, ed., The Lockhart Papers: containing menoirs and commentaries upon the affairs of Scotland, from 1702 to 1715 , by G. Lockhart . . , 1817, 2 vols. 
Works: Nos. 56, 100, 183, 195, 209, 228, 248, 300.

Logan, Allan. d. ca. 1733. (Fasti). Although often termed a renowned witch hunter, Allan Logan seems to have been a well-known but undistinguished Presbyterian clergyman. He was a respected writer, particularly during the Simson affair when he contributed several items to that controversy; and certainly he was popular in his ministry at Torryburn, where he went in 1695. In 1717 he translated to Culross in Dunfermline where he remained. On more than one occasion he was mentioned in connection with committees in the General Assembly. In 1727 his overall condition was altered for the better when he inherited the estate of his brother and with it the position as head of the clan Logan. He married a daughter of Robert, Lord Colville of Ochiltree.

G. D. Henderson, "A Professorship goes a-begging," Aberdeen University Review, vol. II, 1933, pp. 25-33; William M'Millan, John Hepburn and the Hebronites; a study in the post-revolution history of the Church of Scotland, [1934], pp. 72-78.

Work: No. 270.

Lowe, Andrew. A. 1714. Andrew Lowe is something of an unknown figure in Anglo-Scottish circles. He wrote one pamphlet in the reign of Queen Anne entitled $A$ vindication of the Church of Scotland, 1714, in which he sought to counter the complaints made by William Dugud who had been presented to a place in Scotland after the passage of the Act Restoring Patronage. The tract, which was printed in London, was dedicated to Sir James Stewart of Goodtrees, who was M.P. for Edinburgh. While Lowe was not a member of the Church of Scotland, he apparently had a good understanding of its structure and workings.

Work: No. 518 .

Mack enzIE, George. 1630-1714. (DNB; Maxwell). George Mackenzie, Viscount Tarbat, first Earl of Cromarty, was by the reign of Anne a politician of rare agility and experience. Highly intelligent, shrewd, and personable, Mackenzie managed through four reigns to retain high office and to impress the monarch with his ability, which was considerable. This flexibility, while politically admirable, aroused the hatred of many in Scotland and England who regarded him as little more than a trimmer. His career began after the execution of Charles I when he was commissioned to raise troops against Parliament, but defeat led to exile on the continent until 1660 and the restoration. In association with Middleton, Mackenzie learned his politics in the turbulent world of restoration monarchy. He secured the position of a Lord of the Session with the title of Lord Tarbat, but a quarrel with Lauderdale meant loss of office and power until a reconciliation and the office of Lord Clerk Register was effected in 1681. From 1681 through 1688 Mackenzie 
dominated Scottish politics and Scotland for Charles and then for James. His career during those years did not endear him to the more stern Presbyterians who regarded him as little less than a religious and political traitor. In 1688, Mackenzie, according to his enemies, disbanded the militia which might have saved Scotland for James II, in order to ingratiate himself with William, who already had secured England. After a brief period of disfavor with a suspicious William, Mackenzie was restored to his office of Lord Clerk Register, although during this reign he enjoyed less favor with the monarch than in previous or later reigns. Anne treated him more kindly, making him a Principal Secretary of State and, in 1703, Earl of Cromarty. In 1705 he was elevated to the position of Lord Justice General and actively supported the union. He was dismissed in 1710. In his politics as in his religion, Mackenzie was not a stickler for consistency; he was ambitious and he did trim, but once aligned he gave good service. Surprisingly for one so politically active, he also wrote many pamphlets on religious and political issues in Scotland; even more surprising, these constitute one of the largest and most influential blocks of tracts on the union.

P. W. J. Riley, "The formation of the Scottish ministry of 1703," SHR, vol. XLIV, 1965, p. 117; Athol L. Murray, "The Lord Clerk Register," $S H R$, vol. LIII, 1974, p. 141; William Ferguson, "The making of the Treaty of Union of 1707," SHR, vol. XLIII, 1964, p. 97; Dorothy Middleton, The life of Charles, 2 nd earl of Middleton, 1957, pp. 179-180; William Fraser, The Earls of Cromartie. Their kindred, country, and correspondence, 1876,2 vols.

Works: Nos. 3, 140, 212, 232, 260, 284, 364, 378, 396, 430, 489, 501.

MackenzIE, Roderick. f. 1695-1707. This staunch Scotsman was the long suffering secretary of the Company of Scotland; from its very first days through to its dissolution he fought for it and defended it. No one could doubt, over those long and increasingly difficult years, his devotion to that company or to Scotland, for he had no use for the English, and not much for those Scots who refused to assist the company. His action with regard to Captain Green and to the Worcester illustrate not only his dedication and determination to punish those whom he felt responsible for the bad luck of the company, but also his bitterness and fanaticism. Little is known of his life after 1707, when the company was rounded up and all its goods sold, but it is possible that he suffered from want in his last days.

George Pratt Insh, The Darien Scheme, 1947; Andrew Lang, A History of Scotland from the Roman occupation, 1907, vol. IV, pp. 100-105.

Works: Nos. 141, 414.

Mackworth, Humphry. 1657-1727. (DNB). Mackworth might best be described as a promoter or projector-for most of his career he was identified with various schemes, including one for mines in Wales. Born the second, and therefore the poorer, son of a successful Cromwellian politician, Mackworth 
was forced to make his own way. He entered the Middle Temple in 1675, and was called to the bar in 1682 . His marriage in 1686 greatly improved his finances, and by 1695 he was associated with a scheme to develop collieries and copper mines and smelting works in Wales. During much of the reign of Anne his name was associated with this project, which, while initially successful, floundered through opposition within and without. Its collapse brought a demand for an investigation, and in 1710 Mackworth was voted guilty of violations of the charter by the House of Commons, which acted in part out of political pique. Since 1700, Mackworth had been in most Parliaments either as a Member for Cardiganshire or for Totnes. Both in Parliament, and in the political pamphlets which he authored, he was a tory supporter. His interest in Scotland was not great, and indeed his Letter from a Member of Parliament to his friend in the country, 1705, is interested in Scotland only as an adjunct to English political questions. Recent scholarship shows that he may have been the author of the Memorial of the Church of England.

Lester M. Beattie, John Arbuthnot: Mathematician and Satirist, 1935, p. 171; William Rees, Industry before the Industrial Revolution incorporating a study of the Chartcred Companies of the Society of Mines Royal and of Mineral and Battery Works, 1968, vol. II, pp. 520-578; Mary Ransome, "Sir Humphry Mackworth ... ," University of Birmingham Historical Journal, I, 1948, pp. 232-254. See also, J. A. Downic's forthcoming study of "Rolert Harley and the Press."

Work: No, 201.

M'Murdo, John. 1680-1720. (Fasti). M'Murdo is one of the more obscure of the Scottish writers of the period and contributed but one tract to the abjuration controversy. He was a clergyman, educated at Edinburgh, where he received his M.A. in 1697. He was ordained and settled in at Torthorwald in 1702. In his religion he was a learned but moderate man who was unwilling to allow the religious extremists to prevail. His politics might be inferred from his actions in 1715 when he raised a band of local men to defend the government against the Pretender. He died in 1720.

Work: No. 27.

Manningham, Thomas. 1651 ?-1722. (DNB). Thomas Manningham, one of the more popular and successful ministers of the reign of Anne, was graduated from New College, Oxford, where he was a fellow from 1671-1681; he received his B.A. in 1673 and his M.A. in 1676/7. After tutoring, he was presented to the rectory of East Tisted in Hampshire. His preaching so impressed Charles II that the King sought a position to assist him and in 1684 made him Preacher at the Rolls. From 1689 to 1692 he was Headmaster of Westerham Grammar School and in 1691 rector of St. Andrew, Holborn. During the reign of William and Mary, he was chaplain in ordinary and from 1692-1693 canon of Windsor. In 1708/9 he was made dean of Windsor and, in 1709, to the surprise 
of many, Bishop of Chichester. Throughout his career he was a whig and a man of character. His sermon preached 1 May 1707 was but one of many which he published from 1679 until his death; in that sermon he preached reconciliation and conversion of the Presbyterians by example rather than force.

Charles Joln Abbey, The English Church and its Bishops 1700-1800, 1887, vol. I, pp. 160 . 161; Anthony A Wood, Athenae Oxonienses, 1967 reprint, vol. IV, col. 555-556.

Work: No. 394.

Marshall, Nathaniel. d. 1730. (DNB). At the time of the union, Nathaniel Marshall was a young Anglican minister with a growing reputation as a preacher, but with no publications to his credit. He had attended Emmanuel College, Cambridge, where in 1702 he received the LL.B. degree. During the reign of Anne he was vicar of St. Pancras and lecturer of Aldermanbury in London, but it was only after the death of Anne that his career prospered. The Prince of Wales recommended him to the King for a position as one of his chaplains, and in 1716 he was created rector of the united parishes of St. Vedast, Foster Lane, and St. Michacl-le-Querne, in the city of London. In 1722 he was made canon of Windsor. Although he published his sermons during the reign of George I, his publications during the reign of Anne were few. His sermon preached 1 May 1707 was characterized by moderation, and is typical of the low Anglican approach to the union.

J. Meres, ed., The Historical Register: containing an impartial relation of all transactions, foreign and domestick. . ., vol. XVII, 1730, p. 16.

Work: No. 384.

Menzies, John. One pamphlet concerned with Capt. Thomas Green is credited to a John Menzies of London, but little is known of him. He apparently was distinct from the Rev. John Menzies, who was writing as late as 1680; there is no evidence of other publications by a John Menzies between 1680 and 1714. In his Observations on the trial of Captain Green, 1705, he made a plea for understanding for Scots residing in England and for Scots justice, which he refused to condemn without cause.

Work: No. 274.

MoncriefF, George. George Moncrieff, often described as Moncrieff of Reidne (or Reedy) and Myres, was a Commissioner for the shire of Fife in the old Parliament of Scotland. $\mathrm{He}$ had agreed with Walter Stuart that there were too few provisions in the Act of 1702 to protect the church. After the union he wrote $A$ brief account of the elections in the north of Britain, 1708, to protest what he saw as the disappearance of unity among the Scots M.P.'s in the British Parliament, as well as the increasing insecurity of the Church of Scotland. Little else is known of him. 
Work : No. 45.

Morer, Thomas. fl. 1688-1708. (Maxwell). Although the author of one of the most famous accounts of Scotland to be published during the reign of Anne, Thomas Morer is an obscure figure about whom little is known. From internal evidence drawn from his Short account of Scotland, he was an Anglican chaplain to an English regiment stationed in Scotland just before or after the revolution. In 1690 he collaborated with John Sage and Alexander Monro, Episcopalians in Scotland, in the writing and publication of An account of the present persecution of the Church in Scotland. This well-known work sought to vindicate the Episcopalians and to attack the Presbyterians for their actions against the Episcopalians. During the reign of Anne he also published several sermons; but it was his $A$ short account of Scotland, 1702, which earned him a reputation as an acute observer of life in Scotland. When the second edition appeared, he was described as "The late Rev. Thomas Morer, minister of St. Ann's within Aldersgate," and it seems fairly certain that he spent most if not all of the reign of Anne in that ministry.

Work: No. 399.

Nicolson, William. 1655-1727. (DNB). A controversial prelate, politician and scholar, William Nicolson was the first bishop appointed by Anne and certainly one of the most active and intelligent of the Anglican prelates of her reign. He was born in Cumberland; one of the more important aspects of his life was his interest and involvement in the historical, political, and religious life of the border country of England and Scotland. Educated at Queen's College, Oxford, he early showed an interest and ability in ancient and modern languages and in historical and antiquarian studies. While respected then and later for his intellectual abilities, he also exhibited a carelessness or haste in his work which madc him an easy mark for his critics. From 1679 when he secured a position as chaplain to the Bishop of Carlisle, his career prospered with considerable rapidity. In 1681 he was made vicar of Torpenhow but in 1698/9 he was translated to Addingham. In 1682 he had been made archdeacon of Carlisle. Under the patronage of the Musgrave family, he secured the bishopric of Carlisle in 1702, and assumed a seat in the House of Lords as a tory. He soon, however, shifted his position to one more in accord with the whigs, prompted partly by his firm support for the war against France and for the Protestant succession, partly by his personal feud with Dean Atterbury at Carlisle. By the time the whigs began to recover their hold on the government in $1705 / 6$, he was sharply identified with them. His support for the schism bill in 1714, however, alienated some whig leaders and he did not receive the English preferment he expected after the Hanoverian succession. Nonetheless, in 1718 he moved to the richer see of Derry in Ireland and in 1726/7 was made Archbishop of Cashel and Emly-but he did not live to occupy that position. 
Nicholson is unusual in that he exhibited an intcrest in Scotland throughout the reign of Anne; unlike most Anglican prelates, he knew a good deal about the north. In the reign of William he made several trips to Scotland where he was well received and worked with Scots in the preparation of his Scottish Historical Library. While a firm supporter of the established church in England, he agreed that compromise was necessary in regard to the Episcopalians in Scotland, whom he felt would have to settle for a toleration, not a restoration, of their church. He supported the union but continued to demand full protection for the Anglican church in England. Overall, Nicholson would have to be counted among the more enlightened churchmen-and indeed, Englishmen-in regard to Scotland.

Francis Godwin James, North Country Bishop; A biography of William Nicolson, 1956; Edward Carpenter, Thomas Tenison, Archbishop of Canterbury; his life and times, 1948, pp. 178-187; Francis Godwin James, "The Bishops in Politics, 1688-1714," in Confict in Stuart England: Essays in Honour of Wallace Notestcin, 1960, ed. William Appleton Aiken and Basil Duke Henning, pp. 246-248.

Works: Nos. 44, 188, 362.

Oldfield, Joshua. 1656-1729. (DNB). A distinguished Presbyterian minister, Oldfield studied at Lincoln College, Oxford, and at Christ's College, Cambridge, but did not graduate since he refused to subscribe. For some years he was a tutor and chaplain in various households, including that of the Foleys and the widow of Sir John Lort. By 1681 he was at Fetter Lane as an assistant to John Turner, an ejected Presbyterian minister; he himself was ordained in 1687. By 1691 he was in Oxford where he had a congregation, but he removed from there in 1694 to Coventry where he was co-pastor with William Tong. In 1695 he began his famous academy, which provoked the ecclesiastical authorities to call him before them for teaching without a license. After years of litigation, the case was dismissed by William III who disapproved of such attacks on dissenters in England. In 1699 he returned to the London area as minister at the Globe Alley in Southwark and as principal of the academy which he brought with him. In London this teaching work earned him a high reputation. His intellectual interests brought him into friendship with both Locke and Newton whom he impressed with his intelligence and learning. In 1709 Edinburgh University awarded him a D.D. degree. During the reign of George I he continued as a respected teacher and minister more interested in teaching than in preaching. His publications were numerous, but his sermon preached 1 May 1707 would not be included among his better works. It was a rather thin sermon, which sought to avoid all references which might anger the Anglicans and which sought to stress the positive advantages which the union would bring to England, the Anglicans, and religion in general.

Alexander Gordon, ed., Freedom after ejection: a review (1690-92) of Presbyterian and Congregational Nonconformity in England and Wales, 1917, p. 323; Walter Wilson, The 
history and antiquities of Dissenting churches and meeting houses . . , 1814, vol. IV, pp. 160-165.

Work: No. 177.

OllYFFe, John. 1676-ca. 1743. (DNB). The Rev. John Ollyffe was the third generation to bear that name; and since all three were clergymen, this John Ollyffe III often is confused with his more successful father. The first John Ollyffe apparenty was an ejected clergyman of Wivelsfield in Sussex who by 1647 had settled at Arundel, where his son John Ollyffe was born. This second John Ollyffe was minister first at West Almer (1673-1693) and then at Dunton (1693-1717). He was a moderately successful Anglican clergyman with several publications to his credit, most of them either sermons or religious tracts. The third John Ollyffe was more obscure. He was at the rectory of Hedgerley in Buckinghamshire from 1699 through 1743, and it was this John Ollyffe who published a sermon preached on 1 May 1707. It was a typical Anglican sermon seeking reconciliation among Protestants and hoping to make the best of a union which was not agreeable to them but which was desired by the Queen. Ollyffe stressed the positive aspects whenever possible and held out the hope of a further union or a conversion to Anglicanism by the Presbyterians in Scotland.

Work: No. 390.

Paterson, William. 1658-1719. (DNB). With John Law, William Paterson ranks as one of the more interesting of the early eighteenth-century promoters of commercial ventures. Though born in Scotland, he was raised in England. Through travel and trade, he acquired a considerable knowledge of commerce and banking on the continent, in England, and in the Americas. Before 1688 he was prominent among merchants in the Netherlands supporting the invasion of England, and after 1688 was among the first rank of merchants in London interested in new and potentially rewarding projects. He supported and invested in the new Bank of England, but by 1695 had withdrawn from that enterprise and was seeking new investments. After 1695, he increasingly focused his attentions on the Company of Scotland which must rank as his greatest idea and his most solid failure. For four years he advised, promoted, invested in, and worked with that company, but the directors increasingly rejected his advice. He accompanied the first expedition to Darien and narrowly escaped with his life, returning to Edinburgh in 1699 a wiser but much poorer man. It is doubtful if he ever recovered either his reputation or his moneys from that debacle. He went to London and advised William on several. schemes, but was most prominent in the negotiations for the union. He not only wrote in its support, for he undoubtedly felt it was the only way for Scotland to gain economic advantages, but also worked in Edinburgh in 1706 to 
calm fears and to encourage support for the union. Despite these activities, he did not gain recompense for what he had lost in the Darien venture; it was not until 1715 that George I and Parliament passed a bill to repay him.

J. Keith Horsefield, British monetary experiments, 1650-1710, 1960, pp. 125-143; Saxe Bannister, The writings of William Paterson . . , 1858, 2 vols.; George Pratt Insh, The Company of Scotland trading to Africa and the Indics, 1932; George Pratt Insh, The Darien Scheme, 1947.

Works: No. 122, 174, 276, 305.

PAxton, Peter. d. 1711. (DNB). Peter Paxton was a Londoner, best known today for his political and economic writing; but in the early eighteenth century he also was a prolific writer on medical topics. Educated as a physician, Paxton began his publishing career in 1701 with a medical tract; his last work, published posthumously, also was on a medical topic. He also wrote on politics, and his Civil Polity, 1703, was sufficiently well written to warrant inclusion by Locke among those works which should be read by a gentleman. On economic matters, Paxton was a free trader who wrote two tracts on that subject, including one concerned with the consequences of a union between England and Scotland. Paxton died before 1711, leaving behind several important works on a variety of subjects but little of a biographical nature.

J. A. W. Gunn, "The Civil Polity of Peter Paxton," Past and Present, No. 40, 1968, pp. 42-57.

Work: No. 344 .

PEAD, Deuel. d. 1727. A graduate of Trinity College, Cambridge, Deuel Pead was an Anglican clergyman of orthodox opinions but with a somewhat unorthodox career. In 1671 he was a chaplain in the navy; but by 1683 he was in the American colonies with Maj.-Gen. Robert Smith who was returning to the colonies from a visit to London. Pead settled in Virginia and for seven years was a successful colonial divine. In 1691 he returned to England as chaplain to the Earl of Newcastle (later the Duke) and as minister of St. James, Clerkenwell, wherc he remained until his death. He preached and published on numerous ceremonial occasions, though his published sermons tend to be rather ordinary affairs dedicated to the glorification of the monarch or the day. His sermon preached 1 May 1707 is no exception. In that sermon he sought to cmphasize the role of the Qucen in the union, and the duty owed to her as monarch. It was this respect for constituted authority that marks all of his sermons. In that same year, 1707, he was made rector of Newland St. Lawrence, Essex.

Richard Beale Davis, ed., "A sermon preached at James City in Virginia the 23d of April 1686 bctore the loyal Society of Citizens born in and about London and inhabiting Virginia. By Deuel Pead Minister of Middlesex County in Virginia," William and Mary Quarterly, 3rd series, vol, XVII, 1960, pp. 371-394. 
Work: No. 163.

Pitcairne, Archibald. 1652-1713. (DNB; Maxwell). In the Edinburgh of his day, Archibald Pitcairne might be described as a brilliant local maverick whose medical, political, and religious views shocked the town, but whose roots there prevented any strong action against him. He was born into an Edinburgh trading family which claimed descent from an old Fife family. He was educated first at Edinburgh where he received his M.A. in 1671. Having persuaded his father that law and not the church should be his career, he studied at Paris, where he discovered an interest in medicine and mathematics. He received his M.D. degree from Rheims in 1680 and returned to Edinburgh to practice medicine and to write on medical subjects. From then until his death, he wrote on such subjects as the circulation of the blood, and his medical treatises earned him an international reputation as a brilliant if somewhat unorthodox thinker strongly influenced in medicine by mathematical interests. These medical views brought him into controversy not only in Edinburgh but throughout Europe; at no time was he unchallenged. To this Pitcairne added Jacobite views which from time to time forced retirement from Edinburgh. In 16921693 he went to Leyden to lecture but remained there only a year. In his religion, Pitcairne was more of a deist than an Episcopalian, but in any case he mercilessly twitted the Presbyterians of Edinburgh whom he regarded as bigots and fools. His affinity for satirical verse, in Latin, was well known in Edinburgh where many suffered from it. He also wrote two plays which reflected his often bitter view of Edinburgh and its religious and political establishment. Pitcairne was a brilliant physician with a bitter tongue, a quick wit, and unacceptable political and religious views.

Terence Tobin, ed., "The Assembly" by Archibald Pitcairne: A critical edition . . , 1972, pp. 10-19; J. O. Bartley, Teague, Shenkin and Sawney, being an historical study of the earliest Irish, Welsh and Scottish characters in English plays, 1954, p. 155; L. Jollcy, "Archibald Pitcairne," Edinburgh Medical Journal, vol. LX, pp. 39-51; Terence Tobin, Plays by Scots, 1660-1800, 1974, p. 222.

Work: No. 147.

Pix, Mary. 1666-1709. (DNB). Mary Pix was one of several well-known female dramatists and poets writing in the late seventeenth and early eighteenth centuries. She was the daughter of a vicar of Nettlebed in Oxfordshire and the wife of a merchant tailor of London. Her first play appeared in 1696 and was followed by others throughout the reigns of William and of Anne. Her greatest successes were in comedy and not in drama or poetry. Little is known of her life except her capacity for drink, her size (which was considerable), and her affability. She possessed little in the way of formal learning and her poetry has not won great appreciation. 
Nancy Cotton Pearse, "Mary Pix, Restoration Playwright," Restoration and 18th Century Theatre Research, XV, no. 1, 1976, pp. 12-23.

Work: No. 295.

PyLE, Thomas. 1674-1756. (DNB). A relatively young minister at the time he preached on 1 May 1707, Thomas Pyle was a graduate of Caius College, Cambridge and one of the more brilliant students which his college had produced in several years. In 1707 he was minister of St. Nicholas's Chapel in King's Lynn, Norfolk. From 1709 he also held the rectory of Outwell, and from 1710-1711 that of Watlington. A firm whig, he supported the union and the Hanoverian succession. Being from Lynn, he also was associated with Robert Walpole, then Member of Parliament for Lynn. This combination of loyalties led him to hope for preferment. His activities in the Bangorian controversy in support of Bishop Hoadly led to hopes for patronage from that direction as well. Despite some minor preferments, Pyle was not successful, and lived his last years a disappointed man. In his sermon of 1 May, Pyle sought to present a reasonable, moderate, and conciliatory theme: in company with most of the low Anglicans, he hoped for the best from a union which in religious matters was not to his liking.

Work: No. 263.

Ridpath, George. 1660?-1726. (DNB). Daniel Defoe, Charles Leslie, and George Ridpath together account for a considerable portion of the more influential and interesting materials published on the Anglo-Scottish question during the reign of Anne. Ridpath was a Scot born in Berwickshire and educated at Edinburgh. His affinity for intrigue and controversy was apparent carly in his life, and he was forced to flee into England in 1681 for anti-papal activities in Edinburgh. By 1687 he was in the household of Lord Wharton, the great whig manager of the reign of Anne; and by 1693 he already was in the thick of the Anglo-Scottish debates with attacks in the press upon the Episcopalians. Having little or no money of his own, Ridpath already was rumored to be in the pay of the government and to be a spy upon Dr. Monro and his Episcopalian exiles in and around London. In 1695 he translated Sir Thomas Craig's Scotland's Sovereignty and thus activated and enlivened the debate among historians and antiquarians over Anglo-Scottish relations. In the reign of Anne he would assist Anderson in his contributions to that debate. Ridpath's versatility was undoubted. He wrote on the great controversy over the immorality of the stage, contributed to the Darien debate, and published items on the Scottish succession question, the union, toleration for Episcopalians in Scotland, and the Oath of Abjuration. Few if any issues involving Scotland escaped his notice. The views which he advanced were his own in part; without doubt he supported Scottish independence and sovereignty, but 
he also wrote for a living, and his publications undoubtedly received support from anti-union men, perhaps including the Duke of Hamilton, in Scotland. On religious issues he was a Presbyterian who needed little encouragement to write against the Episcopalians there. On issues relating to England, he was a whig and in his pamphlets (and in The Flying Post: or, The Post-Master, which he edited for almost the entire reign of Anne), he championed whig views. In 1713 he fled to the continent to avoid the authorities who sought him, but he returned after 1714 and received some small rewards from a grateful George I. After 1714, however, he never approached the quantity nor the quality of the works written during the height of the great political debates of the reign of Anne.

While Ridpath is mentioned in almost every recent work on the reign of Annc, he has never received the attention which he deserves.

Works: Nos. 10, 58, 86, 107, 157, 224, 247, 289, 303, 321, 322, 361, 423.

Robeson, Alexander. 1675 ?-1761. (Fasti). A Presbyterian minister of Scotland, Alexander Robeson was a native of Roxburghshire, licensed by the presbytery of Kelso in 1696 and ordained in 1697. For most of his career he was minister of Tinwald and his career seems to have been a quiet one-except for the publication in the reign of Anne of a tract on the Oath of Abjuration and another in the reign of George I involving a purely internal religious question. William Stewart, "The Rae Press at Kirkbride and Dumfries," Papers of the Edinburgh Bibliographical Sociesy, vol. VI, p. 114.

Work: No. 271.

Rose [Ross], Alexander. 1647-1720. (DNB; Fasti; Maxwell). One of the most controversial of Episcopalian churchmen in Scotland, Alexander Rose was born into an old family in the north of Scotland and was educated at Aberdeen and at Glasgow under Gilbert Burnet. His first position of note was as minister at Perth, but he subsequently became Professor of Divinity at Glasgow University and Principal of St. Mary's College, St. Andrews. In 1687 he was appointed Bishop of Moray but before he could assume his position he was transferred to Edinburgh as bishop. It was in that office that he faced the revolution of 1688. At the Convention of Estates in March of 1689, he sat with the other bishops and opened the proceedings with prayer, but withdrew when that assembly abolishcd episcopacy as the established church. On 11 April he was deprived of his offices in the church and retired to private life. His actions thereafter satisfied few. He neither led nor sanctioned Jacobite movements which might have restored the reign of James II and episcopacy to Scotland, nor did he participate in the various plots including those of 1708 and 1715. His retirement from political life was complete and was in contrast to that of Alexander Monro and others in the church. Rose's attempts to pre- 
serve and to continue the Episcopal succession in Scotland aroused considerable controversy then and later. His most public activities were in connection with efforts to raise moncys in Scotland and England for the deprived Episcopal clergy who were left without income after 1688.

Work: No. 143.

Rymer, Thomas. 1643?-1713. (DNB). Best known as an antiquarian, Thomas Rymer was a critic and dramatist as well as a writer of political tracts and occasional verse. He left Sidney Sussex College, Cambridge, without taking a degree, and then read law at Gray's Inn before abandoning that profession in turn to write criticism and to compose tragedy. His first important critical work was published in 1674, and in 1677 he wrote an unproduced play which abounded with royalist sentiments but which showed little evidence of dramatic ability. His royalist views led Rymer into a work entitled $A$ general draught and prospect of government in Europe, 1681, in which he upheld the monarchy against the Parliament. His most important work of criticism, however, was published in 1692, the same year in which he was appointed Historiographer Royal. Encouraged by Halifax and Somers, he began to compile materials for a massive collection of treaties, agreements and the like, to be entitled Foedera conventiones. ... The first volume of this multi-volumed work appeared in 1704, and the last five volumes after his death. It is upon this massive and most impressive work that his reputation rests. While engaged in this study, Rymer inevitably intruded into the Anglo-Scottish controversy surrounding the medieval history of the inter-relation of those two powers, and it was in this context that his letters to Bishop Nicolson should be placed.

Curt A. Zimansky, The critical works of Thomas Rymer, 1956, 1971; William L. Sachse, Lord Somers: a political portrait, 1975, p. 202; P. R. Tyler, An account of the life and writings of Sir Thomas Craig of Riccarton, 1823, p. 306; Denys Hay, "The Historiographers Royal in England and Scotland," SHR, XXX, 1951, pp. 22-28; Earl Miner, "Mr. Dryden and Mr. Rymer," PQ, LIV, 1975, pp. 137-151; James M. Oxborn, "Thomas Rymer as Rhymer," $P Q$, LIV, 1975, pp. 152-177.

Works: Nos. 235, 482, 483.

Seron, William. 1673-1744. Born into an old and established family, William Seton was the son and heir of Sir Alexander, first baronet, whom he succeeded in 1719 . Before 1700 Seton already was deeply involved in politics and already had written a tract which caused him to be imprisoned briefly in 1702. From 1702 Seton sat in the General Assembly for Aberdeenshire and in 1703 was Commissioner for Public Accounts. In 1705 he was General Collector of the Scottish bishops' rents and in 1706 was appointed a commissioner for the union, which he supported. In support of the union he wrote and published several tracts which urged an even greater union than that which was effected. After 
the union he sat in the first Parliament of Great Britain, but in 1708 withdrew to Pitmedden where he remained in retirement until his death in 1744.

Peter Hume Brown, History of Scotland, 1911, vol. III, pp. 112-117; Sir Bruce Gordon Seton, The House of Seton, 1941, vol. II, p. 610; G. H. Healey, ed., The Letters of Daniel Defoe, 1955, p. 179; John Gray, ed., Memoirs of the life of Sir John Clerk of Penicuil, Roxburghe Club, 1895, p. 51.

Works: Nos. $351,424,432$.

SETTLE, Elkanah. 1648-1724. (DNB). A dramatist and "city poet" for London, Elkanah Settle left Trinity College, Oxford, without receiving a degree, and settled in London where he built a reputation as a playwright and for a brief time enjoyed the patronage of the court of Charles II. His quarrels with his fellow writers were legendary, but he was particularly unfortunate in his squabble with Dryden who wasted little time dealing with him. While not totally without ability, Settle was unable to survive on his craft alone, and was active in politics during the reigns of Charles II and James II. At no time, however, was he able to do much more than react to changing political conditions which directly affected his life. By 1688 he was trusted by few, having altered his politics too often to carry much weight with either the tory or the whig party. In 1691 he secured the unofficial title and position of "City Poet" for London, and between 1691 and 1708 was responsible for staging pageants on special days and for composing ceremonial poetry for special events. His works on the union were examples of this and resemble other works for similar occasions in many phrases. Although he also continued to write for the stage, neither his occasional verse nor his plays provided for his old age, and he died in most reduced circumstances.

"A list of works in Guildhall Library by, or relating to, Elkanah Settle, 1648-1724," Guildhall Miscellany, II, 1967, pp. 418-423; Frank H. Ellis, ed., Poems on A fairs of State, vol. VI, p. 253; Pat Rogers, "Pope, Settle, and the Fall of Troy," Studies in English Litcrature, XV, no. 3, 1975, pp. 447-458; F. C. Brown, Elkanah Settle, 1910.

Works: Nos, 53, 131.

SHARP, Isaac. Isaac Sharp, curate of Stepney, was not unknown in the reign of Anne as a controversial Anglican clergyman and writer of pamphlets in defense of the church. Nor was he untraveled, for in 1686 he was in Italy and in the next year came to Stepney where it is possible that he had previously studied or taught in a local academy. In 1706, when both Tutchin and Defoe attacked him, he was curate of Stepney and a fairly well-known representative of high church doctrine. He sometimes was confused with Archbishop John Sharp.

Works: Nos. 37,38 .

StbBald, Robert. 1641-1722. (DNB; Maxwell). Sir Robert Sibbald was a man 
of considerable ability and wide ranging interests. Born in Edinburgh, he decided on medicine as his chosen profession and pursued his studies at Edinburgh, Leyden, Paris, and London. Upon his return to Scotland, he settled in Edinburgh where he not only practiced medicine but also actively pursued an interest in botany, which led to the establishment of the Royal Botanic Garden. His keen observation of the indigenous plants of Scotland led to several discoveries of rare plants. Sibbald's medical career likewise prospered. In 1681 he helped to found the Royal College of Physicians, served as its president in 1684 , and in 1685 was appointed the first professor of medicine at the University of Edinburgh. In 1682 Charles II appointed him court physician and in that same year made him Geographer Royal of Scotland. In this latter area he published several interesting geographical studies and sought to gather materials for even more detailed studies. As a courtier Sibbald also enjoyed some success at the courts of Charles II and James II. Under the influence of his patron, the Earl of Perth, he converted, in 1685, to Roman Catholicism, and was forced to flee to London because of the outburst against him. Shortly thereafter, he renounced his conversion and returned to Edinburgh. During the reigns of William and Mary and of Anne, Sibbald increasingly turned his attention to antiquarian studies where he made several important contributions. Sibbald assisted William Nicolson in 1699 and 1701 with his Scottish Historical Library, but Nicolson had asserted the dependence of the Church of Scotland on the see of York in its early days and this provoked a reply. Sibbald wrote to set the record straight, but in doing so advanced his own idea that it was the Episcopal church which had defended the liberties of the Church of Scotland. This theme, established in 1702, was further defended in 1704 in his An answer to the second letter to the Lord Bishop of Carlisle.

Douglas Duncan, Thomas Ruddiman: A study in Scottish scholarship of the early eighteenth century, 1965, p. 50; W. J. Couper, "Andrew Symson," SHR, vol. XIII, 1915, pp. 54-55; The Autobiography of Sir Robert Sibbald, Knt., M.D. To which is prefixed some account of his MSS., 1833.

Works: Nos. $35,236$.

Sinclatr, Archibald. d. 1719. (Maxwell). Sir Archibald Sinclair was apparently the third and youngest son of Sir Robert Sinclair, a royalist, advocate, and Member of Parliament for Berwickshire. For his loyalty to Charles II, Sir Robert was created a baronet in 1661. Sir Archibald, who was admitted as an advocate in 1686, became a Judge of the Admiralty in 1687. The revolution of 1688 did not conclude his career, for in 1690-1702 he was a Member of Parliament for Wick and he was knighted in 1697. In his religious views, he was an Episcopalian, and two of his three pamphlets are concerned with a toleration for the Episcopalians.

Work: No. 448. 
Smith, James. 1680?-1736. (Fasti). In 1712 when he published $A$ dialogue betwixt a minister of the Church of Scotland. ..., James Smith was a young Presbyterian minister only that year promoted from Morham to Cramond. His later career was moderately successful, for he was chosen Moderator of the Assembly in 1723, and in 1732 was elected to a professorship of divinity at the University of Edinburgh. He assumed that position in 1733, but in that same year was also chosen Principal of the University. When he died in 1736, he was chaplain to George II. His few published works were religious in nature; indeed, the only work of a controversial nature was his first publication in 1712 .

Works: Nos. 101, 375.

SPENCE, Thomas. Thomas Spence was a political writer of unknown background.

Work: No. 452 .

SpotTrswoode, John. 1667-1728. (DNB). Born into a distinguished family of advocates, John Spottiswoode followed that profession both at Edinburgh where he graduated in 1686 and then under the guidance of James Hay, a Writer to the Signet. In 1696 he was admitted as an advocate and spent his life in that profession. In 1703 he founded lectures in jurisprudence in Edinburgh and edited or wrote textbooks for use in those studies. While primarily an advocate, Spottiswoode also commented on political questions of his day; in particular he wrote one pamphlet on the question of the union which proved useful in the final days of deliberation. In his politics he was a royalist who would have preferred a Protestant Stuart on the throne, and who hoped that the exiled James III might convert to an acceptable religion. By 1706 he was less hopeful of such a conversion, and his pamphlet on the union is more concerned with making the best terms possible with the English.

Douglas Duncan, Thomas Ruddiman: A study in Scottish scholarship of the early eighteenth century, 1965, p. 42; "Speech of one of the barons of the Shire of Berwick," Spottiswoode Miscellany, vol. I (vol. 3), pp. 228-240.

Works: Nos. $437,490$.

Spreull, John. 1657-1722. (Fasti). "Bass John" was a Presbyterian and an apothecary in Glasgow whose religious opinions brought him into conflict with the government of Charles II in Scotland. In 1677 he fled from Glasgow to the continent and then in 1679 to Ireland. While he was in exile, his family was evicted and all of his goods seized, forcing his return to Scotland in 1680 . He wanted to leave with his wife and daughter for Rotterdam; but while still in Edinburgh, he was seized by the authorities, twice tortured before the Duke of York and the Committee of the Privy Council, and on 14 July fined $£ 500$ and sent to the Bass. The Duke of York regarded him as particularly danger- 
ous and he was detained on the prison rock until 1687. After the revolution he was one of the covenanting heroes and lived to become one of the leading merchants of Glasgow. His pamphlet was one of the more important economic tracts of the period.

A. H. Bowic, The Martyr's Crest: Memorial of Bass John Spreull, 1886; T. C. Smout, "The Glasgow merchant community," SHR, vol. XLVII, pp. 64-65.

Work: No. 4 ,

Standen, Joseph. d. after 1726. Among the preachers of the early eighteenth century, Joseph Standen is not wcll known. When he preached his 1 May 1707 sermon he described himself as a minister of Coleford near Frome in Somersetshire. It is likely that he was a student in Alton parish, Hampshire, under Samuel Tonlyns, and that he received a grant from the Congregational Fund Board of some $£ 10$ a year between 1691 and 1693 . From 1713 to 1726 he was at Newbury in Berkshire, but in 1726 conformed to the established church and was made vicar of Speen in Berkshire. His 1 May sermon was a moderate one which sought toleration in matters religious as well as a reformation of manners and the rooting out of vice and profaneness. During the reign of Anne he also published two other sermons.

Our thanks to Mr. J. D. Gowlett, of the Congregational Library, London, for his assistance.

Work: No. 389 .

STFELE, Richard. 1672-1729. (DNB; Sedgwick). The public and private life of Sir Richard Steele has been well documented and explored and little can be added to those accounts. Stecle had little interest in Scotland and wrote little that related to it. $\mathrm{He}$ is included here for one pamphlet, The Crisis; that work deals only marginally with Scotland and then only as one of the two political units which made up the constitutional structure upon which the Hanoverian succession depended. Written as it was at the height of tory influence on the Queen and on the electorate, The Crisis could not fail to provoke a response; Swift, in The Public Spirit of the Whigs, 1714, answered Steele for the government. It was in the first edition of Swift's pamphlet that the famous paragraph on the Scots was included.

Shirley S. Kenny, "Recent scholarship on Richard Steele," British Studies Monitor, IV, 1973, pp. 12-24; Calhoun Winton, Captain Steele: The early career of Richard Stecle, 1964; Rae Blanchard, ed., The Correspondence of Richard Steele, 1941.

Work: No. 93.

STEnNETr, Joseph. 1663-1713. (DNB). A Seventh Day Baptist and hymn writer, Joseph Stennett was born in Abingdon, Berkshire, into a family of Seventh Day ministers. Educated at Wallingford Grammar School and at 
home, he was accounted by all to be one of the great Hebrew scholars of his day and a man thoroughly at home in early Christian history. By 1685 he was in London acting as an assistant to his father, who was attempting to revive a Seventh Day congregation at Pinner's Hall and was working as a schoolmaster. By 1691 Joseph also was an ordained Seventh Day preacher there and an occasional minister to a regular Baptist congregation at Paul's Alley, Barbican. While somewhat too Calvinistic for the more orthodox Baptists, Stennett was recognized as the leader of the Baptists, regular or Seventh Day, in London, and as such presented the address from them to William congratulating him on his escape from the assassination plot. A man of political principle, Stennett resolutely refused to organize an address to Anne on the conclusion of the war with France, and indeed held fast to the whig party throughout the reign of Anne. In this he was joined by Dr. Daniel Williams, leader of the Presbyterians. As a preacher, Stennett was held to be one of the great orators of his day. His sermons were in great demand and from 1695 appeared almost every year in published form. His sermon preached to commemorate the victory at Blenheim earned him thanks from Anne, who also granted him a gratuity. Stennett was an accomplished poet and hymn writer, and throughout the century his hymns remained popular among the Baptists and others. He was said to have contributed poems of a political nature to Poems on Affairs of State. His sermon preached 1 May 1707 was most cautious and limited in its purpose. While recognizing the positive good which might come from union, he sought to avoid anything that would antagonize the Anglican community.

David Bogue and James Bennett, History of Dissenters from the Revolution in 1688, to the year 1808, 1808-1812, vol. II, pp. 285-288; Robcrt Gcorge Torbet, $A$ history of the Baptists, 1950, p. 92; Walter Wilson, The history and antiquities of Dissenting churches ..., 1808-1814, vol. IV, pp. 206-209.

Work: No. 391.

Strachan, William. A. 1694-1712. (Maxwell). Little is known of William Strachan. A William Strachan published one controversial work during the reign of William, but there is no obvious connection between that William Strachan and a William Strachan who in 1712 defended toleration for the Episcopalians in Scotland. Both men were Episcopalians, and the earlier William Strachan might have been a layman living in London and associated with Monro and the Scots Episcopalians there. William Strachan should not be confused with John Strachan, who was deposed at the revolution from his chair of divinity at the University of Edinburgh.

Work: No. 485 .

Stuart, James. 1635-1713. (Maxwell). By the reign of Anne, Sir James Stuart (Stewart/Steuart) of Goodtrees was a respected and well-known figure in the 
legal, political, and religious world of Presbyterian Scotland. Born the son of Sir James Stuart of Kirkfield and Coltness, Lord Provost of Edinburgh, Sir James was controversial as early as the ministry of the Duke of Lauderdale; in 1674 Stuart offended Lauderdale with a published criticism so scathing that Stuart's arrest was ordered and he only narrowly escaped into a temporary exile. His subsequent restoration to royal favor was short-lived, for he was deeply involved in the Earl of: Argyll's plot and was forced to flee to the Netherlands. Therc he laid the foundation for a close cooperation with the Prince of Orange which assisted him after the revolution of 1688. Stuart took advantage of the toleration granted by James II to return to Scotland but it was later that his role in Scottish politics increased. From 1692 to 1709 and again from 1709 he was Lord Advocate of Scotland, but nevertheless opposed the union. He argued that Scotland would lose her sovereignty and that the established Presbyterian Church would be ruined by a toleration to Episcopacy. This intolerant attitude toward toleration and opposition to the Oath of Abjuration are evident in his last publication.

G. H. Hcaley, ed., The Letters of Daniel Defoe, 1955, p. 315; William Cook Mackenzie, Andrew Fletcher of Saltoun, his life and times, 1935, pp. 248-249; A letter from a gentleman in Edinburgh to his friend in London, giving an account of the present proceedings against the Episcopal clergy in Scotland, 1711.

Work: No. 272.

Swirr, Jonathan. 1667-1745. $(D N B)$. Relatively few of the first-rank writers of the reign of Anne wrote on matters pertaining to Scotland. Swift wrote several pieces of minor poetry on the union, which he later published, but only one of his pamphlets directly relates to Scotland. The Public Spirit of the Whigs, published in 1714 as a response to Steele, contained several controversial passages about the Scots peers which had to be deleted from subsequent editions. Certainly Swift, who was a high Anglican and a tory, had little sympathy with the Scots Presbyterians or with Scotland, but with this one exception, he did not bother too much with them. For additional information on Swift, see works by Arthur H. Scouten, Irvin Ehrenpreis, and Herbert Davis.

Work: No. 306.

Symson, Andrew. 1638-1712. (DNB; Maxwell). While best known for his work as a printer of Episcopal tracts in Edinburgh, Andrew Symson was for many years a minister until the revolution ended that career. From 1664 until 1671 he had been clerk of the synod of Galloway as well as minister of Kirkinner, but his congregation there dwindled and in 1686 he moved to Douglas, Lanarkshire. The revolution forced his withdrawal into a hired house where he continued to preach for some months before removing to Edinburgh. At both Kirkinner and Douglas he experienced opposition from the predominant- 
ly Presbyterian congregation, and it might have been those discouragements (plus his own literary inclinations) which drew him into the printing business. Certainly before 1698 he was established as a bookseller in the Cowgate near the foot of Horse Wynd and before 1702 had assumed responsibility for the printing business begun by his son Matthias. While his typography was distinctive, it was not exceptional in quality; indeed, most of his work was of poorer quality. In his politics, he was a Jacobite and in his religion, an Episcopalian. Despite all that, his poem Unio politico-poetico-joco-seria, was for the union.

W. J. Couper, "Andrew Symson Preacher, Printer and Poet," SHR, XIII, 1915, pp. 47-67. Work: No. 505.

Sxmson, David. A. 1706-1723. (Maxwcll). A son of Andrew Symson, David Symson was a printer with his father in Edinburgh, and shared in his family's Jacobite and Episcopalian views. His one pamphlet, attributed to him by Thomas Maxwell, is concerned with the union, and reflects the family tradition of support for that measure. The same pamphlet, however, also is attributed to his father, Andrew. Apparently in 1706 David was applying for the office of "Library Keeper of Holyruidhouss" with the patronage of the Duke of Queensberry, and in 1708 was made Historiographer Royal to succeed Crawford who died in 1706. In 1723 he published an attack on the Presbyterians, but otherwise seems to have escaped public notice.

Denys Hay, "The Historiographers Rayal in England and Scotland," SHR, vol. XXX, 1951, p. 25; T. I. Rae, "The Loudoun Scottish Papers in the Huntington Library," SHR, vol. XILIX, 1970, pp. 227-228.

Work: No. 410 .

TaLbor, William. 1659?-1730. (DNB). A most grand whig divine, William Talbot was fortunate to enjoy patronage throughout his long carcer sufficient to advance him to one of the richest bishoprics in England. Educated at Oriel College, Oxford, from which he received an M.A. in 1680, he was never known for his learning but rather for his grand style of preaching and for his equally grand style of life. He began his career as rector of Burghfield, a living which he soon abandoned for the position of Dean of Worcester, vacated by George Hickes, a nonjuror. In 1699 , with the patronage of William III, he was appointed to the see of Oxford. There he remained until 1715 when George I allowed him to transfer to Salibury and then in 1721 to Durham, worth $£ 8,700$ a year. A whig, Talbot refused to abandon his principles in 1710 and voted to impeach Henry Sacheverell, a clergyman much esteemed by the tory party. A beautiful speaker with a marvelous command of the language, Talbot preached the 1 May 1707 sermon at St. Paul's and thus gave the official sermon for that day of celebration. It was an eloquent, short sermon preached by a master at 
pleasing the royal ear. It said nothing which might offend the Queen or which could in any way be misunderstood, and it safely ignored the one issue sure to antagonize the high church, religion.

Charles John Abbey, The English Church and its Bishops 1700-1800, 1887, vol. I, pp. $157-$ 158; Henry L. Snyder, ed., The Marlborough-Godolphin Correspondence, 1975, vol. II, p. 765.

Works: Nos. 41, 386.

TAte, Nahum. 1652-1715. (DNB). As Poet Laureate of England, Nahum Tate suffers by comparison even with some of the other somewhat undistinguished poets who have held that office. By all accounts, contemporary and later, he was a poet of mediocre ability who nonetheless produced the required commemorative poem without too great an effort. A graduate of Trinity College, Dublin, in 1672, he was in London soon thereafter and by 1677 was known as a poet and later as a dramatist able to imitate or edit plays by Shakespeare, Webster, or Fletcher. His own pieces were not without merit, but they would not be ranked among the best of restoration drama. In 1692, with the support of the Lord Chamberlain, the Marquis of Dorset, he was appointed Poet Laureate. In 1702, he was reappointed by Anne. Throughout the reigns of both monarchs he produced the expected pieces of verse, and in 1696 collaborated with Nicholas Brady on A New Version of the Psalms, which enjoyed widespread use throughout the century. While constantly seeking patronage and reward, he was unable to secure his position in the reign of George I, and died in 1715 deeply in debt.

Frank H. Ellis, ed., Poems on Afairs of State, vol. VI, p. 148.

Work: No. 492.

TAYLOR, Christopher. d. 1723. Born at Taunton and educated at an academy there, Christopher Taylor was ordained a Presbyterian minister in 1687 at Lyme Regis in Dorset. He was a minister at Bath, and after 1699 in London, where he succeeded Richard Bures at Leather Lane. Already known as a moderate, prudent man, he was chosen by the government to accompany Mr. Shute, later Lord Barrington, into Scotland in 1706. While Shute encouraged the nobility and gentry to support the union, Taylor was expected to work with the Presbyterian ministers who feared for the established church in Scotland. That Taylor would preach a sermon on 1 May 1707, therefore, is not surprising, nor is his style unusual among the dissenting ministers in England. It was a safe, moderate sermon which stressed obedience to the Queen and deplored disunity among Protestants in England and in Scotland. Taylor was not a prolific publisher, and his sermon of 1 May is one of two which he presented to the press during the reign of Anne.

Walter Wilson, The history and antiquities of the Dissenting churches, 1808-1814, vol. IV, 
pp. 393-396. Also, our thanks once again to Mr. John Creasey, of Dr. Williams's Library, London.

Work: No. 455 .

Theobald, Lewis. 1688-1744. (DNB). Educated for the law, Lewis Theobald became instead a young man of letters in 1707, at the beginning of a long and controversial career as a poet, dramatist, translator, and commentator in London. Born in Sittingbourne in Kent, he was educated in that town. Early in life he was left an orphan, and always suffered from the need to earn his own living. Finding that law was not to his liking, he began a literary career with the publication of a pindaric ode on the union. This work reflected neither great poetical ability nor great knowledge of the union; rather the union provided an occasion for a poem of a commemorative sort by a young man eager to make his way in London.

Richard Foster Jones, Lewis Theobald, his contribution to English scholarship, with some unpublished letters, 1919; Pat Rogers, Grub Street: studies in a subculture, 1972, p. 208.

Work: No. 294.

Thompson, John. 1647-1710. (DNB). Sir John Thompson, first Baron Haversham, was a troublesome politician in the reign of Queen Anne who most often was to be found with the opposition on any issue of religious or political importance. Born the son and nephew of prominent Cromwellian politicians, John Thompson married the daughter of the first Earl of Anglesey, and was sufficiently reconciled to monarchy to accept a baronetcy when Charles II offered him one in 1673. But he increasingly found himself in opposition to the policies of Charles II and James II, and before 1688 was allied to William of Orange, actively assisting him in his invasion plans. After the revolution Thompson sat for the borough of Gatton and in the Parliament demonstrated political traits which would characterize his career there. Rarely satisfied for long, Thompson drifted away from the court party and his former support for William, and increasingly sided with the opposition. He modified this position, however, during the 1695-96 session, when he supported the administration's budgetary requests and signed the Association. This brought him a longcoveted title and a place on the Commission for the Admiralty, but renewed opposition to government policy led to his resignation in December of 1701 . From then until his death in 1710, Thompson most often was among the opposition. He opposed the Occasional Conformity bill and the various attempts to reach a compromise during the crisis over the Scottish succession. He opposed the Act of Union and vehemently attacked the government in 1708 for not pursuing those who had assisted the Pretender in his abortive "invasion." By 1709-10 he was among the supporters of Harley and Bromley and thus opposed the impeachment of Sacheverell, and agreed with him that the church was in 
danger. Always a minor politician, he was well known as a loud and longwinded sort, and his contemporaries suspected that he enjoyed opposition. $\mathrm{He}$ usually printed his speeches-more noteworthy for their length than for their content-at his own expense.

William L. Sachsc, Lord Somers: a political portrait, 1975, pp. 236-251; Henry L. Snyder, Charles Spencer, third Earl of Sunderland, as Secretary of State, 1706-1710 . . , 1964, pp. 159, 275; Douglas Coombs, The conduct of the Dutch; British opinion and the Dutch alliance during the War of the Spanish Succession, 1958, pp. 116-127; Henry Horwitz, Revolution Politicks: the career of Daniel Finch, second Earl of Nottingham, 1968, pp. 202-204; Henry Horwitz, Parliament, policy and politics in the reign of William III, 1977; J. A. Downie, "The Commission of Public Accounts and the formation of the Country Party," EHR, XCI, 1976, pp. 33-51; The life, birth, and character of Joh. L. Haversham. With his last speech in defence of Dr. Sacheverell, in Parliament, 1710.

Works: No. 242, 243.

Todv, Hugh. 1658?-1728. (DNB). The Rev. Hugh Todd was an Anglican minister best remembered for his long and bitter dispute with Bishop Nicolson over the rights and privileges of the bishop within the see. Born in Cumberland, Todd was educated at Queen's College, Oxford, and at University College, from which he received his D.D. degree on 12 December 1692. In 1684 he was made vicar of Kirkland, but resigned in 1685 to become a prebend of the see of Carlisle. In that same year he was made a vicar of Stanwix, but that charge he exchanged for Arthuret in 1689. In 1699 he became vicar of St. Andrew's, Penrith, and it was in this post that he clashed so often and so violently with his bishop. While William Nicolson, who became bishop in 1702, was a man of uncompromising character, he met his equal in Todd, who, with his friend and dean, Francis Atterbury, held off Nicolson for a year. Todd and Atterbury, however, so strongly asserted their own independence of the bishop that they alienated and frightened the church hierarchy, which in 1708 secured passage of a bill through Parliament establishing the right of the bishop to visitations within the see. Since Nicolson was closely allied by 1708 with the whigs, and since Todd and Atterbury most certainly were identified with the tory party, the struggle between Todd and Nicolson took on all the character of a party fight, which indeed it was. The spectacle of a high churchman, who sought to defend the established church, excommunicated for disobedience to his bishop, illustrates the confusion associated with politics in the reign of Anne. Todd's sermon preached 1 May 1707 , however, was remarkably moderate for a man of his reputation. He stressed the advantages to those who lived on the borders between the two countries, recapitulated their past history, and while recognizing the advantages of conformity to the Anglican Church, did not take an extreme position in this commemorative sermon.

Arthur Tindal Hart, William Lloyd, 1627-1717; bishop, politician, author, and prophet, 1952, p. 252; Francis Godwin James, North Country Bishop; A Biography of William Nicolson, 1956. 
Work: No. 381 .

TolAND, John. 1670-1722. (DNB). Born of unknown parentage in Ireland, John Toland was a brilliant intellectual who was rarely if ever able to secure steady employment, and who therefore was forced to write occasional works of a political or other nature for a variety of patrons. Although reared a Roman Catholic, Toland abandoned that religion as he progressed through Glasgow, Leyden, and Oxford Universities. His religious views attracted increasing attention; and his first book, published in 1696 as Christianity not mysterious, provoked a furious debate among theologians, with Toland then and later denounced as a deist. Throughout his life, Toland's abilities as a writer and intellectual attracted numerous patrons, including such men as Harley, the third Earl of Shaftesbury, and Robert, Lord Molesworth; but his indiscretions and his unorthodox views also made steady employment difficult to maintain. In England and on the continent he at times conversed as an equal with the greatest men of both the intellectual and political worlds, but he died in want. Although he studied in Glasgow, he had little lasting interest in Scotland and thus did not play a great role in the Anglo-Scottish debates.

F. H. Heineman, John Toland and the Age of Enlightenment, 1944; Caroline Robbins, The 18th century Commonwealthman, 1959, 1968; J. G. Simms, "John Toland (16701722), a Donegal heretic," Irish Historical Studies, XVI, 1969, pp. 304-320; J. A. Downie, "Harley, Toland and Shaftesbury: the interaction between practical politics and political jdeologies in early eighteenth century England," British Society for Eighteenth-Century Studies Newsletter, no. 9, 1977, pp. 25-27.

Work: No. 502 .

Vernon, Mr. [Edward]. The author of the poem The Union, 1706, was a Mr. Vernon, described by Foxon as the "Reverend Mr. Vernon" and sometimes identificd as Edward Vernon. Since there were two men of this name active in the Church of England at the time of the union (as well as other men, including Admiral Edward Vernon, who were in England then), it is of doubtful advantage to attribute this poem to any one of them.

Work: No. 507.

WagstafFe, William. 1685-1725. (DNB). William Wagstaffe was a high church rake and wit well known in London circles after 1707 when he arrived in London from Oxford. He was born the son of a rector of good family in Buckinghamshire, and studied at Lincoln College, Oxford, receiving his M.A. degree in 1707 . Through marriage he was related to Thomas Wagstaffe, a physician who influenced his decision to turn to medicine, which he did, obtaining his M.D. degree in 1714. From that date until his death he was best known as a physician, but during the reign of Anne was also a friend of tory churchmen and wits. His sentiments were all on the side of the government of 
Harley and St. John, and in his religion he ardently supported Sacheverell. His publication in this area therefore tended to favor the Queen, the Church of England, and the cstablished structure.

Work: No. 83 .

WeBster, James. 1658-1720. (Fasti; Maxwell). James Webster was a most difficult and determined Presbyterian minister who suffered much during the reigns of Charles II and James II and who caused much controversy himself in the reigns which followed the revolution of 1688 . While still a student at St. Andrews he so provoked Archbishop Sharp that he was forced to leave the university without a degree. Three times before the revolution he was imprisoned for his religious convictions, and in 1688 was ordained to the meeting house at Craigmillar, Edinburgh. He was a man unable to compromise any beliefs and unwilling to allow others to believe or act in any way other than that determined by himself. He stood squarely against any toleration to the Episcopalians and against any dealings with the English. His tracts on the union and his debates with Defoe are among the most harsh of the entire Anglo-Scottish debate. He also opposed the taking of the Oath of Abjuration, the Patronage Act, and all other such legislation of the reign of Anne. His most famous involvement was with Archibald Pitcairne, the notorious wit and skeptic, who sued him after Webster had accused Pitcairne of being an atheist. Webster was not an attractive man nor are his pamphlets pleasant reading.

John Robert Moore, Daniel Defoe, citizen of the modern world, 1958, p. 161; William Lec, Duniel Defoe His Life and recently discovered writings . . . 1869, 1969, pp. 133-136.

Works: Nos. 40, 187, 373.

Williams, Charles. 1679/1680-1718. Charles Williams was a native of Llanurgan, county Brecon, who was educated at St. Mary's Hall, Oxford, receiving his degrec in 1704. He was a lecturer at Petersham, Surrey, and at Isleworth, Middlesex. He died at Little Hallingbury in Essex in 1718. His sermon is more concerned with praising Anne than with Scotland.

J. Foster, ed., Alumni Oxonienses, being the matriculation register of the University, 1500-1714, 1891-1892, p. 1637.

Work: No. 43.

Williams, Daniel. 1643/1644-1716. (DNB). By 1707 Daniel Williams was one of the most influential and respected, if controversial, religious figures of London. Born in or near Wrexham in Denbighshire, he was preaching before he was 19. He spent many years in Ireland, first as chaplain to Mary, Countess of Meath, and then as a preacher in Dublin where Gilbert Burnet was one of his closest colleagues. Before 1687 he was in London, becoming Presbyterian minister at Hand Alley, Bishopsgate, in 1689. He supported the revolution of 
1688 and William III in particular, and was asked in 1701-1702 to lead a delegation to present the congratulations of the nonconformist ministers to Queen Anne. His dedication to the Hanoverian succession was constant. In matters of religion, Williams was not trained in theology and throughout his career was suspected of one or another religious "heresy," although he was not particularly interested in abstract theology. By 1707 he was the dean of the nonconformist ministers in London, and his opinion on the matter of the union would have carried considerable weight in dissenting as well as Anglican circles. At his death, he left a considerable fortune to charity and to found a library for use of the dissenters.

William Lee, Daniel Defoe. His life and recently discovered writings, 1869, pp. 277-278; Alexander Gordon, cd., Freedom after ejection: a review (1690-1692) of Presbyterian and Congregational Nonconformity in England and Wales, 1917, p. 384; Roger Patrick David Thomas, Daniel Williams; "Presbyterian bishop," 1964.

Work: No. 453.

Willrson, John. 1680-1750. (DNB; Fasti; Maxwell). A Scot born near Stirling into a wealthy landowning family, John Willison was educated at Glasgow and licensed by the presbytery of Stirling in 1701 . In 1703 he was appointed to the parish of Brechin but it was not until 1708 that the Episcopal minister then in residence finally was evicted from the town and church. The congregation was so Episcopalian in sentiment and so Jacobite in politics that Willison experienced many years of extreme opposition before settling in at Brechin. It was in this atmosphere of suspicion and religious strife that his two pamphlets on the Presbyterian church structure were written. In 1716 he was transferred to Dundee where he worked until his death. His later works, of an evangelical nature, were immensely popular with the mass of the population in Scotland, and his fame belongs much more to the reigns of the Hanoverian kings than to that of Anne.

John Parker Lawson, History of the Scottish Episcopal Church from the Revolution to the present sime, 1843, pp. 291-292; J. H. S. Burleigh, A church history of Scotland, 1960, p. 147.

Work: No. 309.

Wodrow, Robert. 1679-1734. (DNB). One of the most famous of the eighteenth-century ecclesiastical historians, Robert Wodrow was the son of a professor of divinity at the University of Glasgow. He was a graduate of the University of Edinburgh, from which institution he received the degree of M.A., and was appointed University Librarian. His cousin Lord Pollock presented him to the parish of Eastwood near Glasgow, and he remained there from 1703 until his death in 1734. While primarily a historian and antiquarian, he was devoted to his parish, and also engaged in politics within the church. 
His dedication to the Presbyterian cause was absolute and his work reflected his unquestioning loyalty to it and to those who had suffered for it in previous reigns. He was actively involved in the union, and on the accession of George I participated in attempts to abolish patronage. However he refused to be part of attempts to evade the application of patronage while it still was in force. His greatest-if extremely controversial-contribution to the Presbyterian church was his monumental History of the Sufferings of the Church of Scotland, 1721-1722, in which he presented a strong if biased account of that religion before 1688. His extensive correspondence remains one of the most important records for the religious life of Scotland during this period. While opposed to the Oath of Abjuration, against which he wrote, Wodrow was not without restraint and his work does reflect a considerable degree of common sense.

A. M. Starkey, "Robert Wodrow and The History of the Sufferings of the Church of Scotland," Chu'ch History, XLIV, 1974, pp. 488-498; W. J. Couper, "Robert Wodrow and his critics," Records of the Scottish Church History Society, V, 1935, pp. 239-250; W. J. Couper, "Robert Wodrow," Records of the Scottish Church History Socicty, III, 1929, pp. 112-134; The Correspondence of the Rev. Robert Wodrow, Thomas M'Crie, ed., 18421843, 3 vols.; "Correspondence between George Ridpath and the Rev. Robert Wodrow," Miscellany of the Abbotsford Club, I, 1837, Pp. 355-381; Early Letters of Robert Wodrow, Scottish History Society, 3rd series, 1937.

Work: No. 268.

WrIGHT, William. d. 1724. (Fasti; Maxwell). One of the most original of the Anglo-Scottish writers of the reign of Anne, William Wright was a Presbyterian clergyman, the son of Robert Wright of Kilmarnock, and the author of The comic history of the marriage between Fergusia and Heptarchus, 1706. Wright was minister of the Second Charge in Kilmarnock and then from 1711 of the First Charge. He opposed the union and was strongly anti-Jacobite, as can be seen in his publications, but otherwise is comparatively unknown.

Work: No. 82.

Wylure, Robert. 1650-1715. (Fasti; Maxwell). Robert Wyllie was a Presbyterian minister prominent in the early years of the reign of Queen Anne for his defense of presbytery and of the church as established after the Revolution. A graduate of Edinburgh University in 1668, he tutored for a while and was not ordained until 1688. In 1690 he became minister at Yarrow and then transferred to Ashkirk, and finally to Hamilton. His publications all cluster around 1703 and the controversy over toleration within Scotland.

George Lockhart, A dialogue betwixt a Burgess of Edinburgh, and a gentleman lately arrived in Scotland, 1713.

Works: Nos. 175, 192, 202, 440, 514. 


\section{CHRONOLOGICAL INDEX}

$1701172,266,304,349,431$.

$170289,107,108,131,148,220,223,233 \mathrm{~A}, 235,236,251,260$ ?, 264, 284, 285, 320 ?, 362, 399, 435, 437, 482.

$170313,58,111$ ?, 156, 157, 178?, 205, 213, 231?, 236, 237, 247, 252, 253?, 260?, $265,281,282$ ?, 313, 318, 320?, 340, 368, 395, 404, 425, 429, 433, 440, 441, $444,456,473,477,503$.

$17046,10,11,12,14$ ?, 21, 35, 70, 79, 105, 122, 124, 154, 155, 200, 203?, 230, 231 ?, 236, 243, 245, 247, 258, 277, 282 ?, 303, 322, 326, 352, 397, 430, 438, $439,442,450,458,471,484,497,531,535$.

$17053,4,14$ ? , 51, 52, 54, 68, 72?, 77, 81, 84, 110, 113, 116, 123, 129, 131, 151, $160,165,169,170,171,185,186,188,201,217,233$ A, 240, 255, 257, 264, $265,274,276,282$ ? , 291, 293, 321, 327, 330, 339, 344, 348, 349, 367, 376, $414,424,426,428,436,440$ ?, 448?, 451, 470?, 488, 491, 493, 502?, 520, 528 ?, 530.

17068,14 ? $15,16,24,26,29,30,31,37,49,67,72$ ?, 82, 85, 86, 90, 92?, 95?, 103 ?, 104, 107, 117, 118, 119, 120, 121, 125, 127, 128, 129?, 130, 133, 137, $138,140,141,173,174,175,176,190,191,192,193,212,214,215,221,225$, 229, 232, 233, 233A 239, 241, 249, 273, 275, 280?, 290, 298, 307, 308, 310, $314,332,341,345,351,353$ ?, 354 ? $, 355,372,374,378,393,398,399,402$, $406,408,410,411,412,415,419,432,434$ ?, 445, 446, 447, 448?, 457, 459, 460,461 ?, 462, 463, 464, 465, 466, 467, 468, 469, 472, 474, 479, 483, 489, 490, $501,505,513,514,515,516,525,528$ ? , 532, 533.

$17075,34,40,41,42,43,44,46,48,49,53,62,65,72$ ?, 78, 88, 92?, 94?, 95?, $102,106,109,114,134,135,136,146$ ? $, 149,150,153,158,163,167,177,187$, $193,202,206,208,222,242,256,263,278,279,286,287,288,292,294,295$, $296,297,299,305,312,317,324,328,331,333,338,347,354$ ?, 358, 359, $366,373,377,381,382 ; 383,384,385,386,387,388,389,390,391,392,393$, $394,401,407,409,416,417,420$ ?, 452, 453, 454, 455, 461 ?, 481, 486, 492, $494,499,500,504,506,507,510,511,512,524,526,527,528$ ?, 529, 534.

$170819,20,23,28,32,36,38,45,69,94$ ?, 184, 199, 204, 234, 246, 254, 261, 283, 311,316 ?, 319, 334, 342, 350, 420, 427, 509.

1709 9, 63?, 64?, 98, 99?, 110, 115, 131, 162, 182, 197, 199, 211, 218, 289, 356, $480,496,517$.

17102 ? , 17, 18, 55, 57?, 64?, 99?, 139, 144? ?, 152, 159?, 179, 180, 182, 228, 244, $302,325,336,475,498$. 
$171133,39,50,56,59,61,66,168,189,195,209,216,227,250,300,346,361$ ?, $369,370,380,396,495$.

17127,47 ? $, 60,74,75,76,80,83,91,101,142,143,147,161,162,181,196,198$, 207,219 ? 224 ? $, 226,259,262,267,268,270,272,301,309,323,329$ ?, 335, $361,363,364,365,379,400,403,405,413,418,443,449,476,478,485,523$.

$17131,22,25,27,73,93,97$ ? 100, 112, 126, 132, 145, 164, 166, 194, 209, 219?, $269,271,315,343,371,375,421,423,487,508,521,522$.

$171471,74,87,93,96$ ?, 97 ?, 183, 238, 248, 250, 264, 306, 357, 360, 422, 518, 519.

No date 210 . 


\section{UNIVERSITY OF KANSAS PUBBLICATIONS Library Series \\ Editor, JAMES Hriyar}

1. University of Kansas: List of Publications. Compilod by Mary Maud Smelser. 1935. available on request

2. University of Kansas Graduate School Theses, 1888-1947. Compiled by Bessic E. Wilder, 1949.

3. Two Augastan Booksellers: John Dunton and Elmond Curll, by Peter Murray Hill. 1958. $\$ 1.00$

4. New Adventtires Among Old Books: An Essay in Eighteenth Century Bibliography, by William B. Todd. 1958.

5. Catalogues of Rare Books: A Chapter in Bibliographical History, by Archer Taylor. 1958.

6. What Kind of a Business is This? Reminiscences of the Book Trade and Book Collectors, by Jacob Zeitlin. 1959.

7. The Bibliographical Way, by Fredson Bowers, 1959.

8. A Bibliography of English Imprints of Denmark, by P. M. Mitchell. 1969.

9. On the Burning of His Library and On Medical Travel, by Thomas Bartholin, translated by Charles D. O'Malley. 1961.

10. A Bibliography of the Frank E. Melvin Collection of Pamphlets of the French Revolution in the University of Kansas Libraries, by Ambrose Saricks. 1961.

11. Observations on Paper as Evidence, by Allen H. Stevenson. 1961.

12. University of Kansas Graduate School Theses, 1948-1958. Compiled by Bessic E. Wilder. 1961. $\$ 2.50$

13. Six Variant Readings in the First Folio of Shakespeare, by Charlton Hinman. 1961. \$1.50

14. A Petirion Regarding the Conditions in the C.S.M. Prison at Columbia, S.C., Addressed to the Confederate Authorizies by Col. John Fraser. Edited by George L. Anderson. 1961. $\$ 1.50$

15. William Dampier: Seaman-Scientist, by Joseph C. Shipmnn. 1962.

16. Maps of the 16th to 19th Centuries, by Thomas R. Smith and Bradford L. Thomas, 1963.

17. Looking at an Early Map, by R. A. Skelton. 1965.

18. A Bibliography of James Joyee Studies, by Robert H. Deming. 1963.

19. Maps of Costa Rica, by Albert H. Palmerlec. 1965.

20. A Checklist of Linneana, 1735-1835, by Terrence Williams. 1964. Inernational Bibliography of Vegetation Maps, edited by A. W. Küchler. Volume 1: North America, 1965.

22. Four Centuries of Shakespeare Publication, by Giles E. Dawson. 1964.

23. A Guide to the Sst Pu T'iung K'an, by Karl Lo. 1965.

25. Censored: Books and sheir Right to Live, by Elmer Gertz. 1965.

26. International Bibliography of Vegetation Maps, edited by A. W. Küchler. Volume 2: Europe. 1966.

27. Bibliography and Natural History: Essays presented at a Conference convened in luse 1964 by Thomas R. Buckman. 1966.

$\$ 5.00$

28. A Bibliography of 17th Century German Imprints in Denmark and the Duchies of SchlesuigHolstein, compiled by P. M. Mitchell. Volumes 1-2. 1969.

29. Inernational Bibliography of Vegetation Maps, edited by A. W. Kücliler. Volume 3: Union of Soviet Socialist Republics, Asia, and Australia. 1969.

30. Rilke's last year, by George C. Schoolficld. 1969.

Tho Worlds of University Publishing, by Roger W. Shugg. 1968.

32. Bibliographical Contributions, 1. 1969.

33. A Bibliographical Catalogue of the Ellis Collecsion of Ornishological Litcrature. Vol, 1, 1972. $\$ 10.00$

34. The Cuban Revolution of Fidel Castro Viesued from Abroad: an Annotaied Bibliography, by Gilberto V. Fort. 1969.

35. Growth and Change in the Early English Press, by Richmond P. Bond. 1969.

36. International Bibliography of Vegetation Maps, edited by A. W. Küchler. Volume 4: Africa, South America, and World Maps. 1970.

37. Gilbert and Sullivan: Papers presenied at the International Conference held at she University of Kansas in May 1970. Edited by James Helyar. 1971. $\$ 6.00$

38. Watching the Ps and Qs: Ediforial Treatment of Accilentals, by James Thorpe. $1971 . \quad \$ 1.00$

39. A Bibliography of $17 \mathrm{th}$ Century German Imprints in Denmark and the Duchies of Schleswig. Holstein, compiled by P. M. Mitchell. Volume 3. 1976. (Supplement to No. 28)

40. Bibliographical Contributions, 2. 1976. $\$ 2.00$

41. Rilke and his Reviewers: an Annotated Bibliography, by Henry F. Fullenwider. $1978 . \quad \$ 4.00$

42. The Dress of Words: Essays on Restoration and Eighteenth Century Literature in Honor of Richmond P. Bond. Edited by Robert B. White, Jr. 1978. $\$ 12.00$

43. A Critical Bibliography of Dr. Henry Sacheverell, by F. F. Maclan. Edited by W. A. Speck. 1978.

44. Anglo-Scottish Tracts, 1701-1714: a descriptive checklist, compiled by W. R, and V. 13, McI-coll. 1979.

$\$ 12.00$

- Titles marked with an asterisk are now in short supply, and are normally only available to complete the files of institutions maintaining exchange agreements with the University of Kansas Libraries.

The Library Scries and other University of Kansas Publications are offered to learned socictics, colleges and universitics and other institutions in exchange for similar publications. All communications regarding exchange should be addressed to the Exchange Librarian, University of Kansas I.ibraries, Lawrence, Kansas 66045 . Communications regarding sales, reviews, and forthcoming publications in the Library Series, should be addressed to the Editor of Library Publications, University of Kansas Librarics, Lawrence, Kansas 66045. 